UNIVERSIDADE DE SÃO PAULO

FACULDADE DE ECONOMIA, ADMINISTRAÇÃO E CONTABILIDADE

DEPARTAMENTO DE ADMINISTRAÇÃO

PROGRAMA DE PÓS-GRADUAÇÃO EM ADMINISTRAÇÃO

LETÍCIA JULIÃO

Competitividade da viticultura regional e brasileira: uma análise setorial e comparativa com produtores mundiais

SÃO PAULO

2015 


\section{LETÍCIA JULIÃO}

Competitividade da viticultura regional e brasileira: uma análise setorial e comparativa com produtores mundiais

Dissertação apresentada ao Departamento de Economia, Administração e Contabilidade da Universidade de São Paulo como requisito para a obtenção do título de Mestre em Administração.

Área de concentração: Economia das organizações

Orientador: Prof. Dr. Paulo Roberto Feldmann 


\section{FICHA CATALOGRÁFICA}

Elaborada pela Seção de Processamento Técnico do SBD/FEA/USP

Julião, Letícia

Competitividade da viticultura regional e brasileira: uma análise setorial e comparativa com produtores mundiais / Letícia Julião. -- São Paulo, 2015.

$151 \mathrm{p}$.

Dissertação (Mestrado) - Universidade de São Paulo, 2015.

Orientador: Paulo Roberto Feldmann.

1. Vantagem competitiva 2. Viticultura 3. Produtividade I. Universidade de São Paulo. Faculdade de Economia, Administração e Contabilidade. II. Título.

CDD - 658.401 
Nome: Letícia Julião

Título: Competitividade da viticultura regional e brasileira: uma análise setorial e comparativa com produtores mundiais.

Dissertação apresentada ao Departamento de Economia, Administração e Contabilidade da Universidade de São Paulo como requisito para a obtenção do título de Mestre em Administração.

Aprovado em:

Banca Examinadora

Prof. Dr.:

Instituição:

Julgamento:

Assinatura:

Prof. Dr.:

Instituição:

Julgamento:

Assinatura:

Prof. Dr.: Instituição:

Julgamento: Assinatura: 
À minha família, pelos ensinamentos e exemplos de superação e lições de vida. 


\section{AGRADECIMENTOS}

À Faculdade de Economia, Administração e Contabilidade (FEA/USP) pela oportunidade de realização do mestrado.

Ao Professor Paulo Feldmann, pela orientação valiosa e pelas inúmeras reuniões de segundafeira, que foram essenciais para a conclusão deste trabalho.

Às Professoras Silvia Miranda e Sylvia Saes, que contribuíram com ideias valiosas para o meu trabalho na etapa de qualificação.

À Margarete Boteon, que me incentivou a fazer o mestrado e pelos conselhos e contribuições importantes para esta pesquisa, além do grande apoio para a minha vida profissional.

Ao Centro de Estudos Avançados em Economia Aplicada (Cepea) pelo fornecimento dos dados e contatos, sem os quais este estudo não seria possível.

À minha família, principalmente minha mãe Rosângela, minha avó Paulina, meus tios Paulo e Angélica, pelo apoio dado em todos os momentos da minha vida, desde a entrada na graduação até a finalização do mestrado.

Ao meu namorado Leandro, por todo amor, carinho, paciência e pelo incentivo, tanto na realização do mestrado quanto na minha vida profissional. Sem seu apoio não conseguiria ter realizado muitos objetivos.

Às amigas Renata, Fernanda, Larissa e Daia, companheiras que me aguentaram nos momentos mais tensos e por deixarem meus dias mais alegres, e a todo o pessoal do Cepea. À Daia, em especial, pela revisão ortográfica do trabalho.

Aos pais da "Pi", Francisco e Cecília, que me acolheram com todo carinho e atenção durante uma ano e meio em São Paulo; e à "Pi" (Mayra), que mesmo longe sempre foi muito importante para esta trajetória da minha vida.

À Viviane e ao Vinícius, que me auxiliaram com a parte estatística desta dissertação.

Ao Fernando Capello, que sempre me ajudou quando eu chegava com perguntas e mais perguntas sobre a viticultura.

Aos 40 produtores de uva que me atenderam e foram entrevistados por longos minutos para que este trabalho fosse concluído.

E, a todos que tenham contribuído com esta dissertação de alguma forma. 
“A competitividade de um país não começa nas indústrias ou nos laboratórios de engenharia. Ela começa na sala de aula".

\section{Lido Anthony "Lee" Iacocca}




\section{RESUMO}

O setor agrícola brasileiro gera saldos positivos à balança comercial do Brasil, e a fruticultura segue no mesmo ritmo. Dentre as frutas produzidas no Brasil, a uva é uma das que mais impactam na balança comercial, tendo em vista que é amplamente exportada e importada. Este cenário só se tornou possível com a abertura de mercado na década de 90, e, assim, o Brasil pôde se tornar mais competitivo no mercado nacional e internacional. A competitividade é importante para a economia, seja de um país, de um setor ou de uma empresa. No presente trabalho, então, foi realizada uma análise setorial da competitividade da viticultura, fundamentada na produtividade, nos aspectos tecnológicos e no ambiente institucional. Para a análise regional brasileira foi utilizada a técnica de triangulação na metodologia deste trabalho: pesquisa qualitativa (entrevista com produtores das principais regiões produtoras de uva de mesa do Brasil); análise estatística por meio de Modelos Lineares Generalizados de dados secundários (preço nas regiões produtoras de uva de mesa) obtidos no banco de dados do Cepea; e análise documental (com base nas legislações, regras e outros documentos disponíveis). A partir disso foi constatado que o Vale do São Francisco (BA/PE) é a região brasileira mais competitiva, visto que investe mais em tecnologia, tem gestão empresarial (enquanto as outras são marcadas pela agricultura familiar) e consegue se sobressair nas questões de comercialização. Além disso, no Brasil, o ambiente institucional, de um modo geral, não gera grandes vantagens competitivas para nenhum produtor de uva - a exceção são as fortes cooperativas do Nordeste. Para a análise da competitividade internacional, além da análise documental com vistas ao comércio internacional, foram feitas estatísticas descritivas com dados de preço, produção, produtividade, exportação, importação e consumo aparente de uva de mesa do Brasil, Chile e Itália. Os dados foram obtidos nos bancos de dados do IBGE, MDIC, Odepa, Eurostat e USDA. No geral, Chile e Itália têm ambiente institucional mais forte que o Brasil para o comércio internacional de uva de mesa. Mesmo assim, a competitividade internacional brasileira cresceu nos últimos anos frente a Chile e Itália. Assim, pode-se concluir que mesmo com ambiente institucional desfavorável, tanto no mercado interno quanto no externo, o Brasil conseguiu avançar na competitividade entre os anos analisados neste trabalho. Isso se deve, sobretudo, aos investimentos ocorridos na principal região brasileira - o Vale do São Francisco.

Palavras-chave: vantagem competitiva; viticultura; produtividade. 


\begin{abstract}
The Brazilian agribusiness generates profits to the trade balance of Brazil, and the fruit sector follows the same rhythm. The table grape is one of the fruits that impact the trade balance, because it is widely exported and imported. This scenario was only possible to the market opening in the 90s, and thus Brazil was able to become more competitive in domestic and international markets. Competitiveness is important to the economy, whether of a country, of a sector or a company. Thus, a sectorial analysis of the viticulture competitiveness was conducted, based on productivity, technological and institutional environment. In this research, it was used triangulation technique in the methodology to conduct the Brazilian regional analysis: qualitative research (interview with producers of the main producing regions of table grape of Brazil); statistical analysis using Generalized Linear Models of secondary data (price of table grape) obtained in Cepea database; and documental analysis (based on the laws, rules and other documents available). Based on this, it was found that the São Francisco Valley (BA/PE) is the most competitive region in Brazil. This region invests more in technology, has business management (while the others regions are tagged by family farmers) and stands out in the marketing. In addition, in Brazil, the institutional environment, in general, does not generate competitive advantages for grape growers - the exception is the strong cooperatives located in Northeast. The international competitiveness was conducted by descriptive analysis of statistics - price, production, productivity, export, import and apparent consumption of table grape in Brazil, Chile and Italy. Also, a documental analysis of international trade was conducted. Data were obtained from the IBGE, MDIC, Odepa, Eurostat and USDA databases. Overall, Chile and Italy have a stronger institutional environment to international trade of table grapes than Brazil. Anyway, the Brazilian international competitiveness has increased in recent years compared to Chile and Italy. Thus, it can be concluded that even with unfavorable institutional environment, both domestically and external, Brazil was able to advance in competitiveness during the years analyzed in this work. This is mainly attributed to the investments occurred in the main Brazilian table grape region - São Francisco Valley.
\end{abstract}

Key words: competitive advantage; viticulture; productivity. 


\section{LISTA DE FIGURAS}

Figura 1. Saldo da balança comercial da uva de mesa no Brasil ___ 13

Figura 2. Cadeia produtiva genérica da uva de mesa no Brasil __ 17

Figura 3: Estruturas de mercado___ 29

Figura 4. Fatores que influenciam a competitividade de setores do agronegócio ___ 31

Figura 5. O modelo do "Diamante de Porter" para a competitividade ___ 33

Figura 6. As cinco forças competitivas de Porter.___ 35

Figura 7. Evolução da área (em milhões de hectares) com cultivares transgênicos no Brasil ___ 44

Figura 8. Evolução da produtividade total de frutas, em geral (em toneladas/hectare). __ 45

Figura 9. Técnica de levantamento de dados da pesquisa____ 48

Figura 10: Mesorregiões produtoras de uva no estado de Pernambuco no ano de 2012

Figura 11: Mesorregiões produtoras de uva no estado de São Paulo no ano de 2012

Figura 12: Mesorregiões produtoras de uva no estado do Paraná no ano de 2012

Figura 13: Mesorregiões produtoras de uva no estado da Bahia no ano de 2012 _ 53

Figura 14. Evolução das importações brasileiras entre 1998 e 2013

Figura 15: Calendário de colheita das regiões produtoras de uva de mesa ___ 73

Figura 16: Rede do Ambiente Institucional da regional Macro Metropolitana Paulista___ 78

Figura 17: Rede do Ambiente Institucional da região Norte do Paraná ___ 79

Figura 18: Rede do Ambiente Institucional da região de Campinas___ 79

Figura 19: Rede do Ambiente Institucional da regional São José do Rio Preto (SP) ___ 80

Figura 20: Rede do Ambiente Institucional da região do Vale do São Francisco ___ 80

Figura 21: Rede da Tecnologia da regional Macro Metropolitana Paulista ___ 83

Figura 22: Rede da Tecnologia da região Norte do Paraná ___ 84

Figura 23: Rede da Tecnologia da região de Campinas ___ 84

Figura 24: Rede da Tecnologia da regional São José do Rio Preto (SP) ___ 85

Figura 25: Rede da Tecnologia da região do Vale do São Francisco ___ 85

Figura 26: Rede da Comercialização da regional Macro Metropolitana Paulista___ 87

Figura 27: Rede da Comercialização da região Norte do Paraná___ 88

Figura 28: Rede da Comercialização da região de Campinas____ 88

Figura 29: Rede da Comercialização da regional São José do Rio Preto (SP)___ 88

Figura 30: Rede da Comercialização da região do Vale do São Francisco ___ 89

Figura 31: Variação do preço da uva itália ao longo dos anos___ 93

Figura 32: Intervalos de confiança das curvas de preço (em $R \$ / \mathrm{kg}$ ) (a) e a comparação entre as regiões (b) _ 93

Figura 33: Variação do preço da uva niagara ao longo dos anos __ 95

Figura 34: Curvas dos preços médios (RS/kg) da uva niagara em cada região entre 2001 e $2014 \_96$

Figura 35: Evolução da produção (a) e produtividade (b) da uva de mesa de Brasil, Itália e Chile - em índice

100/ano base: $2000 \ldots 107$

Figura 36: Evolução da exportação (a) e importação (b) da uva de mesa de Brasil, Itália e Chile - em índice 100/ano base: $2000 \ldots 109$

Figura 37: Evolução do preço da uva fina branca sem semente, do Brasil, Itália e Chile, comercializada no porto de Roterdã (Holanda) - em US\$ $/ \mathrm{kg} \_111$

Figura 38: Evolução do consumo da uva de mesa de Brasil, Itália e Chile - em índice 100/ano base: $2000 \_113$ 


\section{LISTAS DE TABELAS}

Tabela 1. Produção mundial de uva 11

Tabela 2. Principais estados brasileiros produtores de uvas de mesa 14

Tabela 3. As 10 maiores empresas de fertilizantes e defensivos em 2011

Tabela 4. Ranking com as cinco maiores redes supermercadistas do Brasil

Tabela 5. Regiões de uva de mesa selecionadas neste trabalho

Tabela 6. Evolução da importação de uva de mesa pela União Europeia

Tabela 7: Recursos destinados à agricultura por ano safra (em $R \$$ bilhões)

Tabela 8: Perfil dos entrevistados de cada região produtora 71

Tabela 9: Comparação qualitativa do Ambiente Institucional das regiões produtoras de uva 75

Tabela 10: Comparação qualitativa do nível tecnológico das regiões produtoras de uva

Tabela 11: Comparação qualitativa da comercialização das regiões produtoras de uva

Tabela 12: Comparação geral da competitividade

Tabela 13: Preços médios (R\$/kg) e desvios-padrões observados da uva itália em cada região entre 2001 e 2014

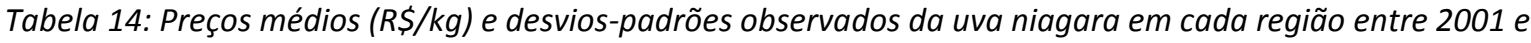
2014

Tabela 15: Acordos Comerciais de Brasil, Chile e Itália e tarifas para a comercialização de uva de mesa entre esses países

Tabela 16: Evolução da produção e da produtividade da uva de mesa do Brasil, Itália e Chile 106

Tabela 17: Evolução das exportações e importações de uva de mesa do Brasil, Itália e Chile 108

Tabela 18: Variedades de uva de mesa exportadas pelo Brasil, Itália e Chile 110

Tabela 19: Evolução do preço nominal da uva fina branca sem semente comercializada no porto de Roterdã (Holanda) - em US\$\$ $/ \mathrm{kg}$

Tabela 20: Consumo aparente de uva de mesa no Brasil, Itália e Chile 112

Tabela 21: Comparação qualitativa dos parâmetros de competitividade internacional de Brasil, Itália e Chile 114 


\section{SUMÁRIO}

Capítulo 1 - Introdução

1.1. Introdução 9

1.2. A viticultura 10

1.2.1. Perfil da produção de uva no Brasil 14

1.2.2. Cadeia produtiva da uva brasileira 16

1.3. Objetivos 21

1.4. Problema de pesquisa 22

1.5. Justificativa 23

1.6. Estrutura do trabalho 26

Capítulo 2 - Revisão Bibliográfica 28

2.1. Estrutura de mercado 28

2.2. Competitividade 29

2.3. O ambiente institucional e as organizações 37

2.4. Tecnologia e produtividade 41

2.5. Hipóteses de pesquisa 46

Capítulo 3 - Metodologia 48

3.1. Metodologia 48

3.1.1. As regiões produtoras de uva selecionadas 49

3.1.2. Amostragem da pesquisa qualitativa 54

3.1.3. Pesquisa Qualitativa 55

3.1.4. Obtenção dos dados secundários 58

3.1.5. Análise documental: o ambiente institucional da viticultura ___ 59

3.1.6. Análise da competitividade regional __ 59

3.1.7. Identificação dos países e comparação da competitividade internacional 62

Capítulo 4 - Análise dos resultados e discussão 66

4.1. Competitividade da viticultura brasileira 66

4.1.1. O Crédito e o Seguro Rural para o produtor de uva no Brasil ___ 66

4.1.2. Perfil dos produtores brasileiros de uva _ 70

4.1.3. Comparação da competitividade das regiões produtoras de uva de mesa __ 74

4.1.4. Análise dos preços ao produtor de uva___ 91

4.1.4.1. Uva itália___ 91

4.1.4.2. Uva niagara__ 94

4.1.5. Considerações sobre a competitividade regional da viticultura___ 97

4.2. Competitividade internacional da viticultura ___ 102

4.2.1. Brasil é pouco competitivo no Ambiente Institucional Internacional __ 102

4.2.2. Avaliação da produção e comercialização internacional de uva do Brasil, Chile e Itália___ 105 
4.2.3. Considerações sobre a competitividade internacional 115

4.3. Análise SWOT da viticultura brasileira 118

Capítulo 5 -Conclusão 120

5.1. Considerações finais 120

5.2. Limitações da pesquisa e sugestões de estudos futuros 122

6. Referências Bibliográficas 124 APÊNDICE 141 



\section{Capítulo 1 - Introdução}

\subsection{Introdução}

O agronegócio é de extrema importância para o Brasil, tendo em vista que o País é líder mundial na exportação de alguns produtos agropecuários - café, suco de laranja, açúcar e carne. Em 2013, as exportações do agronegócio representavam 41\% dos envios totais do Brasil (MAPA, 2014). Em 2014, esse setor movimentava em torno de 22\% do Produto Interno Bruto (PIB) do País (Cepea, 2014). Em 2010, de quatro produtos agrícolas em circulação no mundo, um era brasileiro e a estimativa do Ministério da Agricultura, Agropecuária e Abastecimento (MAPA) é que, até 2030, esse número passe para um terço (de cada três produtos, um seja brasileiro) devido à crescente demanda nos países da Ásia, sobretudo a China (MAPA, 2014).

O setor agrícola brasileiro gera saldos positivos à balança comercial do País (em 2013, foi de US\$ 82,9 bilhões, positivos), e a fruticultura segue no mesmo ritmo. Só no ano de 2013, o saldo da balança comercial de frutas frescas, em geral, teve superávit de US\$ 144 milhões, de acordo com os dados da Secretaria de Comércio Exterior (Secex), do Ministério do Desenvolvimento, Indústria e Comércio (MDIC), disponível por meio do Sistema de Análise das Informações do Comércio Exterior (Aliceweb) (MDIC/SECEX, 2014). Este cenário só se tornou possível com a abertura de mercado na década de 90, e, assim, o Brasil pôde se tornar mais competitivo no mercado nacional e internacional.

A competitividade é importante para a economia, seja de um país, de um setor ou de uma empresa. No agronegócio, segundo Vicente (2005), o mercado é altamente competitivo, sendo necessária a "construção de indicadores de competitividade (...), que possibilitam uma análise mais acurada das vantagens e desvantagens enfrentadas pelas distintas regiões produtoras" (VICENTE, 2005, p. 6).

No Brasil, a produtividade do agronegócio, de maneira geral, é elevada, sendo um dos componentes mais importantes para a competitividade do setor, e a adoção de tecnologias no campo foi imprescindível para que a produtividade da agricultura brasileira tivesse ganhos expressivos nos últimos anos (VICENTE, 2005). Segundo Gasques, Bastos e Bacchi (2009), 
"o crescimento da produtividade tem sido o principal fator responsável pelo crescimento da agricultura" (GASQUES; BASTOS; BACCHI, 2009, pg.72).

A competitividade pode ser difícil de medir, mas para alguns autores que estudaram o assunto (FERRAZ; KUPFER; HAGUENAUER, 1995; HARISSON; KENNEDY, 1997; FARINA, 1999), a produtividade, tecnologia e ambiente institucional são os fatores mais importantes que compõem a competitividade ou a afetam positiva ou negativamente. Deve ser levado em consideração também um indicador de rentabilidade - preço $x$ custo, por exemplo. A partir disso, para a análise da competitividade do presente trabalho será levado em consideração, além da rentabilidade, a produtividade, sempre relacionada à tecnologia, e o ambiente institucional das regiões produtoras.

$\mathrm{Na}$ fruticultura, segmento de estudo deste trabalho, existem algumas particularidades que afetam a competitividade: forte presença da agricultura familiar, mão de obra, concorrência tanto no mercado interno quanto externo, preços bastante voláteis devido à sazonalidade das culturas, problemas fitossanitários, entre outros. No cenário internacional de frutas, o Brasil tem posição de destaque, mas ainda poderia ser mais competitivo frente aos principais concorrentes. Para o aumento da competitividade da fruticultura brasileira, produtores têm de se confrontar com alguns desafios, sobretudo os relacionados com a tecnologia de campo e o ambiente institucional - na comercialização de frutas frescas, em geral, deve se levar em conta vários regulamentos, normas, políticas, barreiras (não)tarifárias e certificações em alguns casos (BRASIL, 2007).

\subsection{A viticultura}

No mundo, a produção de uva somou 67 milhões de toneladas no ano de 2012 (Tabela 1), segundo a Organização das Nações Unidas para Agricultura e Alimentação (FAO), sendo a quinta fruta mais produzida. O país de destaque na produção global é a China (representatividade de 14\%), seguida pelos Estados Unidos (10\%), Itália (9\%) e França (8\%). 93 países constam no ranking de produção de uva, sendo que o Brasil ocupou o $12^{\circ}$ lugar neste ranking, com 1,5 milhão de toneladas produzidas em 2012 (representatividade de 2\%) (FAO, 2014). 
Tabela 1. Produção mundial de uva

\begin{tabular}{clrr}
\hline $\begin{array}{c}\text { Ranking } \\
\mathbf{2 0 1 2}\end{array}$ & \multicolumn{1}{c}{ País } & $\begin{array}{c}\text { Produção } \\
\text { (em t) }\end{array}$ & Participação \\
\hline 1 & China & 9.600 .000 & $14 \%$ \\
2 & EUA & 6.661 .820 & $10 \%$ \\
3 & Itália & 5.819 .010 & $9 \%$ \\
4 & França & 5.338 .512 & $8 \%$ \\
5 & Espanha & 5.238 .300 & $8 \%$ \\
6 & Turquia & 4.275 .659 & $6 \%$ \\
7 & Chile & 3.200 .000 & $5 \%$ \\
8 & Argentina & 2.800 .000 & $4 \%$ \\
9 & Irã & 2.150 .000 & $3 \%$ \\
10 & África do Sul & 1.839 .030 & $3 \%$ \\
11 & Austrália & 1.656 .621 & $2 \%$ \\
12 & Brasil & 1.514 .768 & $2 \%$ \\
13 & Egito & 1.378 .815 & $2 \%$ \\
14 & Índia & 1.240 .000 & $2 \%$ \\
15 & Alemanha & 1.225 .950 & $2 \%$ \\
& Outros & 53.938 .485 & $80 \%$ \\
\hline & Total mundo & $\mathbf{6 7 . 0 6 7 . 1 2 9}$ & $\mathbf{1 0 0 \%}$ \\
\hline
\end{tabular}

Fonte: FAO (2014)

Os principais países produtores contam tanto com viticultura quanto com vitivinicultura. A primeira refere-se à produção de uva para consumo in natura, ou uva de mesa (Vitis $S P$ ), como é popularmente conhecida. A segunda trata do cultivo de uvas viníferas para a produção de suco e vinho. Grosso $\operatorname{modo}^{1}$, com base em dados do IBGE (2014), no Brasil, 39\% da produção foi destinada ao consumo in natura em 2013 e 61\%, para a produção de suco e vinho. No presente trabalho, as análises serão concentradas apenas na viticultura, tendo em vista a importância deste setor para a agricultura familiar.

No Brasil, as primeiras videiras europeias chegaram junto com os colonizadores portugueses no século XV. Com a abolição da escravatura no Brasil, o café entrou em decadência e os imigrantes italianos do estado de São Paulo se tornaram grandes viticultores. Porém, o cultivo esbarrou em problemas de adaptação às condições edafoclimáticas ${ }^{2}$ do País. A produção de uva começou a ter expressão comercial apenas anos após a introdução das

\footnotetext{
${ }^{1}$ Segundo agentes do setor vitivinicultor, basicamente os estados do Rio Grande do Sul e de Santa Catarina destinam a produção de uva para a fabricação de suco e vinho. Assim, a percentagem foi calculada a partir dos dados do IBGE: dividiu-se a soma do volume produzido por RS e SC pela produção total brasileira.

${ }^{2}$ Edafoclimático é relativo ao solo e ao clima.
} 
variedades americanas no Brasil, sobretudo com a variedade s $_{\text {abe }} l^{3}$ no estado de São Paulo, que ocorreu ainda no século XVIII (INGLEZ-DE-SOUSA, 1996). A niagara rosada é a uva de mesa mais produzida no Brasil, mas existe mais de 160 cultivares $^{5}$ de uva adaptadas às condições de clima e solo brasileiros - entre uvas para vinho (viníferas) e as de mesa (com e sem semente) (CAMARGO; TONIETTO; HOFFMANN, 2011).

Um dado que chama a atenção é a produtividade média dos vinhedos brasileiros frente aos de outros países do mundo. Nos últimos anos, alguns países vêm se destacando em termos de produtividade média dessa fruta. O ranking da FAO (2014) mostra que Taiwan registra a maior produtividade média de uva, 35,4 toneladas/hectares. O Brasil figura em sétimo lugar, com rendimento médio de 18,3 toneladas/hectare (FAO, 2014). Quais os fatores que levaram esses países a terem forte competitividade no que diz respeito à produtividade no campo? Vale lembrar que as videiras de cultivares voltadas para o consumo in natura (uva de mesa) registram maior produtividade do que videiras para uvas com destino industrial (suco ou vinho). Segundo autores que estudaram este assunto, a produtividade de um vinhedo destinado ao cultivo de uva de mesa tem sido de 15 a 25 toneladas/hectare, enquanto que a de uva de indústria (suco e vinho) vai de 5 a 15 toneladas/hectare (HOWELL, 2001; CLÍMACO, et al., 2003; ROMBALDI, et al., 2004; ARAÚJO; CORREIA, 2008; WUTKE, et al., 2011).

A uva é uma atividade bastante intensiva em mão de obra, de modo que predominam a agricultura familiar e o pequeno produtor. De uma forma geral, na classificação oficial da agricultura brasileira, o pequeno produtor tem até 50 hectares no Sul/Sudeste e até 200 no Nordeste (IBGE, 2014). Para uva, porém, o setor considera que pequeno produtor teria até 10 hectares no Sul/Sudeste. Mesmo sendo, em boa parte, agricultura familiar, a viticultura é considerada intensiva em mão de obra. Para ser considerada agricultura familiar, é necessário que a renda da família seja originada da atividade do próprio estabelecimento rural, que a mão de obra seja predominantemente da família e que a propriedade tenha até quatro módulos

\footnotetext{
${ }^{3}$ A variedade isabelé de uva tinta, rústica e fértil. Essa variedade necessita de pouco manejo para colheita abundante. Além de uva de mesa, pode ser usada para fabricação de vinhos branco, rosado e tinto que também podem originar o vinagre. Esta uva apresenta boa performancenos climas tropicais do Brasil.

${ }^{4} \mathrm{O}$ cultivo dessa variedade se expandiu na necessidade de produtores paulistas por uma nova variedade. A niagara tem boa aceitação no mercado e baixo custo de produção (frente a outras variedades).

Fonte: Embrapa <http://sistemasdeproducao.cnptia.embrapa.br>

5 A palavra "cultivar", segundo a legislação brasileira, remete a uma variedade vegetal que seja diferente de outras já conhecidas no mercado. O cultivar é desenvolvido através de pesquisas agronômicas e/ou biogenéticas. Fonte: MAPA. Ministério da Agricultura, Pecuária e Abastecimento. DECRETO $\mathrm{N}^{\circ} 2.366$, DE 5 DE NOVEMBRO DE 1997.
} 
fiscais ${ }^{6}$, de acordo com a Lei $\mathrm{n}^{\mathrm{o}} 11.326$, de 24 de julho de 2006, que estabelece as diretrizes para a formulação de políticas para a agricultura familiar (BRASIL, 2006).

Dentre as frutas produzidas no Brasil, a uva é uma das que mais impactam na balança comercial, tendo em vista que é amplamente exportada e importada (Figura 1). O Vale do São Francisco (BA/PE) é o polo exportador de uva, entre outras frutas. Esta região do Nordeste brasileiro é o maior polo de desenvolvimento agrícola irrigado da América Latina. As condições climáticas e de solo do Vale do São Francisco permitem que as uvas amadureçam em 120 dias, sendo que o padrão médio é de 180 dias (DICKEN, 2010).

A uva já foi a fruta mais exportada pelo Brasil, em valores. Em 2013 foia terceira, movimentando 102,9 milhões de dólares, ficando atrás do melão e da manga. As exportações brasileiras de uva de mesa ocorrem principalmente entre setembro e dezembro de cada ano, sendo Europa e Estados Unidos os principais destinos. São enviadas principalmente uvas sem semente. A exportação de uva representou, em 2013, 15\% das frutas frescas brasileiras comercializadas com o mercado internacional. Em importação, a uva também é a terceira fruta mais comprada, movimentando 59,5 milhões de dólares (representando 14\% das compras brasileiras de frutas frescas), ficando atrás da pera (que não é produzida no Brasil) e da maçã. A Argentina e o Chile são os principais países fornecedores. O Brasil compra uvas de mesa geralmente no primeiro semestre de cada ano, período em que a produção nacional é menor, sobretudo das variedades sem semente, as mais importadas (MDIC/SECEX, 2014).

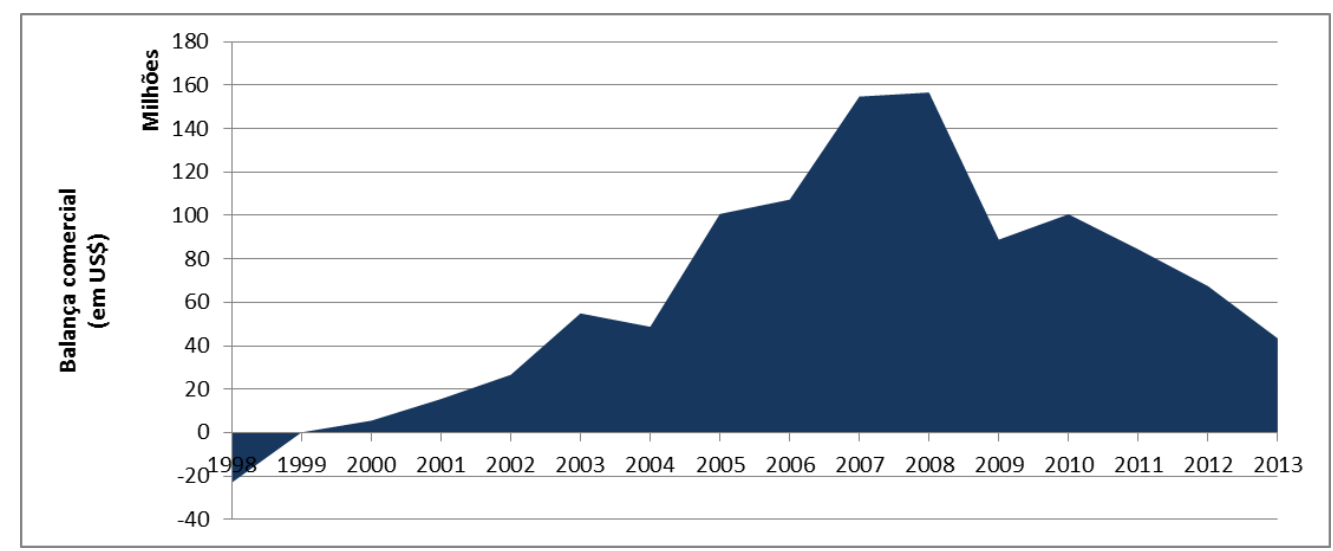

Figura 1. Saldo da balança comercial da uva de mesa no Brasil

Fonte: MDIC/SECEX (2014)

\footnotetext{
${ }^{6}$ Módulo fiscal é uma unidade de medida, em hectares, das propriedades rurais. A quantidade de hectares do módulo fiscal varia conforme a região brasileira que a propriedade está localizada.
} 
Além de ser uma fruta de destaque na economia nacional, a uva também se sobressai frente às outras frutas no que diz respeito ao uso intensivo de mão de obra, constantes investimentos em novas variedades (material genético) e disponibilidade de crédito rural. Porém, ainda faltam estudos que elucidem este cenário. Assim, a uva de mesa foi a fruta escolhida para a análise setorial do presente trabalho.

\subsubsection{Perfil da produção de uva no Brasil}

A uva é a sétima fruta mais produzida (em volume) pelo Brasil, ocupando superfície de 82 mil hectares (total mesa e vinho) em 2012. As uvas de mesa somaram naquele ano 27,8 mil hectares e 603 mil toneladas, sendo que os principais estados produtores foram Pernambuco, São Paulo, Paraná, Bahia e Minas Gerais (Tabela 2) (IBGE, 2014).

Dados do último Censo, 2006, apontam que havia pouco mais de 10,9 mil estabelecimentos produtores de uva de mesa no Brasil, e em nove mil deles, o produtor é o proprietário da terra. Este cenário remete a uma atividade agrícola bastante pulverizada e numerosa - não há concentração de mercado. Destes estabelecimentos agrícolas com produção de uva de mesa, $86 \%$ cultiva a fruta em até 10 hectares, caracterizando a agricultura familiar (IBGE, 2006).

No Sul e Sudeste, mais de $97 \%$ dos produtores de uva de mesa tem propriedades com menos de 10 hectares. Estas propriedades são responsáveis por $96 \%$ da produção de uva de mesa no Sul (Paraná) e $81 \%$ no Sudeste (São Paulo e Minas Gerais). Já no Nordeste, há maior número de grandes produtores, sendo que a agricultura familiar representa $41 \%$ da produção no Nordeste, $91 \%$ das propriedades tem menos de 10 hectares (IBGE, 2006). Vale ressaltar, ainda, que, no Brasil, a viticultura começou em terras paulistas (INGLEZ-DE-SOUSA, 1996).

Tabela 2. Principais estados brasileiros produtores de uvas de mesa

\begin{tabular}{cccc}
\hline \multicolumn{4}{c}{ Os cinco principais estados produtores de uva de } \\
mesa
\end{tabular}




$\begin{array}{crrr}\text { São Paulo } & 214.684 & 172.868 & 158.781 \\ \text { Paraná } & 78.614 & 79.052 & 80.000 \\ \text { Bahia } & 62.292 & 52.808 & 58.287 \\ \text { Minas Gerais } & 10.831 & 12.725 & 11.537\end{array}$

*Previsão de safra do IBGE

Fonte: IBGE (2014).

A maior parte dos produtores de uva de mesa, assim, faz parte de uma agricultura familiar. Segundo Médici (2009), a forma de organização familiar na agricultura pode ser adotada conscientemente ou não. Há casos em que a família se reúne e decide investir em um determinado cultivo agrícola. No entanto, na maior parte dos casos, os indivíduos estão em uma atividade agrícola porque nasceram e cresceram nela - é uma tradição. Um grande problema, porém, enfrentado por produtores rurais familiares, é a sucessão - além do menor tamanho das famílias com o passar dos anos, os filhos dos agricultores tem encontrado melhores oportunidades nos centros urbanos, abandonando o campo (BUAINAIN; ROMEIRO; GUANZIROLI, 2003).

A agricultura familiar não pode ser analisada de maneira geral, segundo Buainain, Romeiro e Guanziroli (2003), tendo em vista que é um universo heterogêneo no que diz respeito ao mercado comprador e à capacidade de gerar e acumular renda. Além disso, no que diz respeito à gestão, o custo desta atividade é menor frente à de empresas maiores, e a supervisão é facilitada (BUAINAIN; ROMEIRO; GUANZIROLI, 2003). Por outro lado, a gestão familiar em empresas pode ter impacto negativo na produtividade, tendo em vista que pode não criar incentivos e oportunidades de promoção à mão de obra (BLOOM et al., 2010).

No eixo Petrolina-Juazeiro (PE/BA), por outro lado, de acordo com o Sebrae, pode ser observada maior concentração de grandes empresas profissionalizadas na produção de uva de mesa - possuem boa infraestrutura, packing houses $^{7}$ e tecnologia. Além disso, os produtores dessa região possuem os sistemas de irrigação mais modernos (AGROINDUSTRIAIS, 2005). Segundo Bloom e colaboradores (2010), empresas mais profissionalizadas, como as dessa região, tem impacto positivo na produtividade, podendo induzir o crescimento da empresa. Este polo produtor conta, ainda, com o Brazillian Grape Marketing Board (BGMB), criado para gerenciar a comercialização da uva do Vale do São Francisco destinada ao mercado internacional - o BGMB conta com 22 associados entre produtores, cooperativas e empresas

\footnotetext{
${ }^{7}$ Packinghouse é um estabelecimento de recebimento, limpeza e embalagem da fruta. Parte dessa estrutura pode ser composta por câmaras frias para melhor conservação das frutas.
} 
de maior porte. Além disso, a Cooperativa Agrícola de Juazeiro (CAJ) também é um importante player no negócio da uva no Brasil, sobretudo para as vendas no mercado interno - a CAJ tem cerca de 40 associados (AGROINDUSTRIAIS, 2005).

\subsubsection{Cadeia produtiva da uva brasileira}

Cadeia produtiva é um conceito que deriva do Sistema Agroindustrial (SAG) proposto inicialmente por Davis e Goldberg (1957). Segundo Farina e Zylbersztajn (1991), a cadeia produtiva é um ramo do SAG, sendo uma boa unidade de análise, tendo em vista que ela expressa as transações comerciais e de tecnologia entre os diversos elos. A cadeia produtiva abrange atividades desde a produção no campo até a distribuição do produto final.

Com relação à cadeia da uva de mesa, segundo dados do Censo de 2006, de toda produção naquele ano - 252 mil toneladas -, 92\% foi vendida - 8\% acumulam as perdas, estoques e consumo (humano e animal) na propriedade. Da produção vendida, os destinos foram, em ordem de importância: venda direta a intermediários (geralmente atacadistas), mercado internacional (exportação), venda ou entrega a cooperativas, venda direta ao consumidor, venda direta a indústria, entrega à empresa integradora e venda, entrega ou doação ao governo - apenas os dois primeiros correspondem a quase $80 \%$ das vendas (IBGE, 2006).

A comercialização da uva, porém, é diferente em cada região produtora do País, tendo em vista os diversos sistemas de produção e de pós-colheita, a tecnologia utilizada e a forma de organização dos produtores (AGROINDUSTRIAIS, 2005), além, é claro, do calendário de produção de cada região. Genericamente, no entanto, podemos dizer que a maior parte dos produtores adquire os insumos dos fornecedores; produzem a uva e a vendem para diversos segmentos e até ao consumidor final, como mostra a Figura 2. Os produtores podem, ainda, receber assistência técnica de engenheiros agrônomos contratos particularmente, e de órgãos presentes em vários estados do País. 


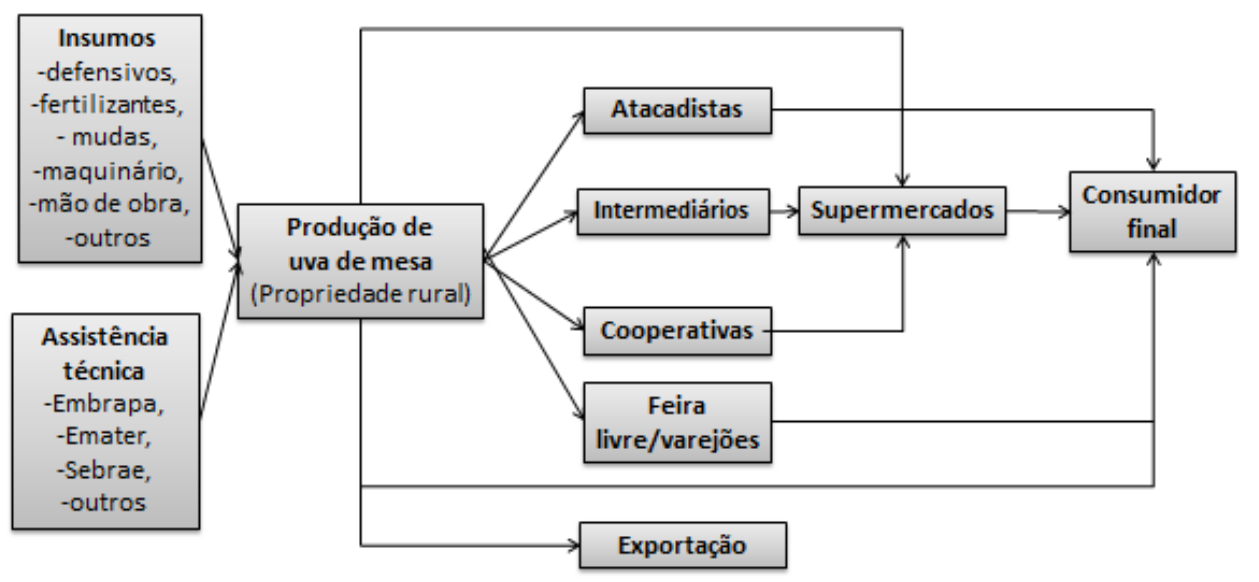

Figura 2. Cadeia produtiva genérica da uva de mesa no Brasil

Fonte: Desenvolvido pela autora

Do início da cadeia, os fornecedores de insumos, assim, são as empresas de defensivos, fertilizantes, mudas, tratores, equipamentos e, ainda, a mão de obra, entre outros. Os defensivos e fertilizantes, juntos, representam entre $12 \%$ e $16 \%$ dos custos de produção da uva entre pequenas e grandes propriedades no Vale do São Francisco (BA/PE), por exemplo, conforme levantado por Deleo e colaboradores (2012).

A indústria de fertilizantes e defensivos é marcada por muitas multinacionais. No Brasil, dentre as 50 maiores empresas do agronegócio em 2011, 10 são deste segmento, conforme ranking divulgado na Revista Exame (2012) (Tabela 3). Os fertilizantes são importantes na agricultura tendo em vista que auxiliam no aumento da produtividade das lavouras por suprirem as necessidades da planta por nutrientes (VAN RAIJ et al., 1996). Já os defensivos têm sua importância na capacidade de prevenir ou destruir pragas e doenças na agricultura, estas que já chegaram a ser responsáveis por até $40 \%$ das perdas agrícolas na década de 90. A utilização da tecnologia de químicos na agricultura (fertilizantes e defensivos) está associada ao aumento da produção no campo (SILVA; COSTA, 2011).

Tabela 3. As 10 maiores empresas de fertilizantes e defensivos em 2011

\begin{tabular}{|c|c|c|}
\hline \multicolumn{3}{|c|}{$\begin{array}{c}\text { As } 10 \text { maiores empresas do setor de fertilizantes e } \\
\text { defensivos em } 2012\end{array}$} \\
\hline Ranking & Empresa & $\begin{array}{l}\text { Vendas (em US\$ } \\
\text { milhões) }\end{array}$ \\
\hline 1 & Basf & $5.755,10$ \\
\hline 2 & Heringer & $4.833,50$ \\
\hline 3 & Bunge Fertilizantes & $4.473,60$ \\
\hline
\end{tabular}




$\begin{array}{cll}4 & \text { Bayer CropScience } & 4.410,70 \\ 5 & \text { Syngenta } & 3.846,00 \\ 6 & \text { DuPont } & 3.436,10 \\ 7 & \text { Mosaic } & 3.292,40 \\ 8 & \text { Vale Fertilizantes } & 2.985,10 \\ 9 & \text { Yara } & 2.831,60 \\ 10 & \text { Ultrafértil } & 2.328,50\end{array}$

Fonte: Elaborado pela autora com base no ranking da Revista Exame (2012)

A mão de obra, por sua vez, é um dos maiores gastos com a produção na fruticultura, de modo geral, não apenas para a uva. A mão de obra tem sido um gargalo neste setor do agronegócio, tendo em vista a intensa migração de trabalhadores do campo para a indústria civil nos últimos anos, conforme relatos de produtores de uva ${ }^{8}$.

A mão de obra é um ativo muito importante para a viticultura, sendo até um item que não tem ganho de escala. Por exemplo, na região nordestina do Vale do São Francisco, varia bastante conforme a escala da propriedade - em pequenas propriedades (até 12 hectares), este insumo representa 19\% dos custos totais; em médias propriedades (até 35 hectares) representa $34 \%$ com os gastos; e em grandes propriedades (cerca de 250 hectares), $31 \%$ dos custos (DELEO et al., 2012). Na viticultura familiar, os gastos com mão de obra também são elevados. De acordo com Capello (2014), que estudou os custos de produção da variedade rústica niagara rosada em diferentes regiões do estado de São Paulo, a mão de obra é o item que mais pesa no custo operacional (não contabiliza os investimentos e o custo de oportunidade da terra), principalmente por conta do número elevado de tratos manuais, como podas, desbrotas, amarrios e colheita, além da roçagem e pulverização que ainda é feita manualmente em parte das propriedades. Na região de Campinas, por exemplo, de um custo operacional de $\mathrm{R} \$ 1,23 / \mathrm{kg}$ de uva niagara conduzida sob o sistema espaldeira, $\mathrm{R} \$ 0,42 / \mathrm{kg}$ foi gasto somente com mão de obra, ou seja, 34\%. Com relação ao custo total nessa região, a mão de obra pesa com 23\% (CAPELLO, 2014).

Quanto à assistência técnica, além das particulares contratadas pelos produtores, é recebida também de órgãos governamentais, como a Empresa Brasileira de Pesquisa Agropecuária (Embrapa), sobretudo a Embrapa Uva e Vinho, a Empresa de Assistência Técnica e Extensão Rural (Emater), o Serviço Brasileiro de Apoio às Micro e Pequenas Empresas (Sebrae), entre outras assistências locais.

\footnotetext{
${ }^{8}$ A autora visitou duas propriedades de uva na cidade de Jundiaí e entrou em contato com alguns agentes do setor por telefone para entender a cultura da uva e a opinião sobre a falta de mão de obra, sobretudo a qualificada foi unânime entre os produtores consultados.
} 
A primeira, a Embrapa uva e vinho, foi fundada em 1975 em Bento Gonçalves (RS) como um braço da Embrapa que está ligada ao Ministério da Agricultura, Pecuária e Abastecimento (MAPA). A Embrapa uva e vinho ainda conta com mais duas unidades, em Vacaria (RS) e em Jales (SP). A Embrapa uva e vinho atua em Pesquisa e Desenvolvimento (P\&D) da fruticultura temperada para viabilizar a competitividade sustentável das culturas. Ela ainda conta com um programa de transferência de tecnologia ao produtor rural, que está associado ao programa de P\&D. A Embrapa disponibiliza aos produtores novas variedades de uva de mesa, informações sobre o sistema de produção, etc. (Embrapa, 2014a).

A Emater tem um trabalho semelhante e está presente em vários estados do Brasil Paraná, Minas Gerais, Rio Grande do Sul, Pará, Goiás e Rio de Janeiro. A Emater, porém, não conta com P\&D, sendo apenas uma empresa voltada ao assistencialismo rural (Emater, 2014). No estado de São Paulo, o trabalho da Emater é realizado pela Coordenadoria de Assistência Técnica Integral (Cati), criada em 1967 e vinculada à Secretaria de Agricultura e Abastecimento do Governo do Estado de São Paulo (Cati, 2014).

Com todos os insumos comprados, e às vezes, com assistência técnica, os produtores de uva realizam as atividades de campo. O ciclo da uva inicia com o plantio das mudas já enxertadas ${ }^{9}$ no campo (ou a realização da enxertia no campo, diretamente). Após um ano de implantação dessa muda, o produtor realiza as podas de formação, que tem por objetivo dar a forma adequada à planta. Existe também a poda de produção, que elimina ramos em excesso, ramos doentes, deixando apenas aqueles que darão frutos. Essa poda geralmente é realizada após o período vegetativo da planta, quando ela guarda nutrientes para o próximo ciclo de produção. A videira, então, começa a gerar os brotos, que quando em excesso em um mesmo ramo também são raleados, para que a produtividade e a qualidade das frutas seja satisfatória. Assim, a videira frutifica e o produtor colhe os frutos para as vendas. Vale lembrar que em meio a esse ciclo, os produtores devem realizar os tratos culturais, como adubação, aplicação de defensivos, entre outros produtos químicos (Embrapa, 2014b).

Com a uva já colhida e embalada, os produtores se atentam à comercialização. Segundo Souza e colaboradores (1998), a comercialização é um dos maiores entraves que o produtor tem que enfrentar, tendo em vista que muitas vezes pode faltar informação sobre o mercado, e o produtor acaba recebendo menos pelo produto do que poderia. O custo de

\footnotetext{
${ }^{9}$ Enxertia é um processo que une duas partes de variedades diferentes da uva (ou qualquer outra árvore frutífera) que se desenvolvem como um ser único. São utilizadas duas plantas no processo: o cavalo ou porta-enxerto, que contribui com a raiz, assegurando a nutrição; e o enxerto, que é a planta das características que se busca na fruta a ser colhida - é o enxerto que forma a copa e frutifica. Fonte: Embrapa. Disponível em: <http://www.infoteca.cnptia.embrapa.br/bitstream/doc/859550/1/rt92enxertiadefruteiras.pdf>
} 
comercialização da uva de mesa no Vale do São Francisco, por exemplo, pode ser de $27 \%$ quando a escala de produção é média ou grande e, até a $43 \%$ em pequena escala de produção. Nos custos de comercialização estão incluídos o frete, a embalagem, as despesas com packinghouse e certificações e o custo de operação da câmara fria.

Dentre os principais compradores estão os atacadistas (e intermediários), supermercados, em menor frequência e importância também estão as feiras livres, além das próprias cooperativas que adquirem as frutas dos produtores cooperados. Todos esses vendem a fruta para o consumidor final - às vezes o produtor também vende direto a esse último elo da cadeia. Parte dos produtores, ainda, envia a fruta ao mercado internacional, sobretudo aqueles situados no Vale do São Francisco.

Dentre os compradores, os atacadistas ficam nas Centrais de Abastecimento (Ceasas). As Ceasas têm "papel de destaque na comercialização (...) nas suas respectivas áreas de influência, muito embora as estruturas físicas de determinadas Centrais, já se encontram obsoletas e localizadas em áreas em processo de saturação" (BARRETO-JÚNIOR, 2004, p. 25). Porém, esse distribuidor vem enfrentando muitos problemas em termos comercialização - é alto o custo para manter um boxe em uma Central de Abastecimento -, a logística é deficitária, falta padronização e classificação de mercadorias, entre outros problemas. Neste sentido, as Ceasas vêm perdendo espaço no que diz respeito à comercialização de frutas e hortaliças (SOUZA et al., 1998). No Brasil, a Ceagesp - Companhia de Entrepostos e Armazéns Gerais de São Paulo - é a principal Ceasa.

Já os supermercados vêm ganhando cada vez mais espaço no segmento de frutas, legumes e verduras (FLV) no Brasil e no Mundo. Nos países desenvolvidos, por exemplo, a distribuição de alimentos, perecíveis ou não, está concentrada em super e hipermercados (SOUZA et al., 1998). No Brasil, os supermercados, e em especial as grandes redes, tem investido no setor de FLV, pois traz bons ganhos à empresa. Além disso, esse setor tem buscado cada vez mais fazer laços sólidos com os produtores rurais, comprando diretamente deles, sem passar por um intermediário - o supermercado é, ainda, o elo mais exigente em qualidade entre os compradores (MARTINS; MARGARIDO; BUENO, 2007). Segundo a Associação Brasileira de Supermercados (Abras), o setor supermercadista faturou em 2013 $\mathrm{R} \$ 229,4$ bilhões, $13 \%$ mais que no ano anterior e os cinco maiores supermercadistas do Brasil (Tabela 4) representam pouco mais de $60 \%$ desse faturamento. 
Tabela 4. Ranking com as cinco maiores redes supermercadistas do Brasil

As 5 maiores redes varejistas do Brasil

\begin{tabular}{cllrr}
\hline $\begin{array}{c}\text { Ranking } \\
\mathbf{2 0 1 3}\end{array}$ & \multicolumn{1}{c}{ Razão Social } & Sede & $\begin{array}{c}\text { Faturamento } \\
\text { Bruto em 2013 } \\
\text { (R\$) }\end{array}$ & $\begin{array}{c}\text { Número } \\
\text { de lojas }\end{array}$ \\
\hline & Companhia Brasileira de Distribuição (Pão de & & & \\
1 Açúcar) & SP & 64.405 .475 .962 & 1.999 \\
2 & Carrefour Com Ind LTDA & SP & 34.012 .572 .214 & 241 \\
3 Wal-Mart Brasil LTDA & SP & 28.477 .467 .543 & 544 \\
4 Cencosud Brasil Comercial LTDA & SE & 9.611 .363 .497 & 221 \\
5 Companhia Zaffari Com. Ind. & RS & 3.765 .000 .000 & 30 \\
\hline
\end{tabular}

As feiras-livres, que ainda são um dos principais compradores de uva de mesa dos produtores rurais, estão perdendo espaço na comercialização de frutas, legumes e verduras, sobretudo por conta da ascensão dos supermercados. Porém, ainda é uma das principais formas de o consumidor adquirir frutas, legumes e verduras, tendo em vista a oferta de produtos mais frescos (MARTINS; MARGARIDO; BUENO, 2007).

Quanto ao consumidor final, tem aumentando o consumo de FLV nos últimos anos, em busca cada vez mais de uma vida saudável. Em relação ao consumidor de uva no Brasil, o maior consumo per capita está no Sul do País, mas em volume total, o Sudeste lidera as compras dessa fruta, tendo em vista o maior número de pessoas nessa região. Porém, o consumo por habitante ainda é baixo - dados da Pesquisa de Orçamento Familiar (POF) de 2008 mostram que, na média brasileira, o consumo de uva foi de 0,76 kg/habitante/ano, mostrando grande potencial de crescimento frente a outras frutas. A uva é consumida em todas as classes de renda familiar, sendo que a classe alta (mais de 10 salários mínimos) consome cinco vezes mais por ano que a classe baixa (até três salários mínimos) (SILVEIRA et al., 2012).

\subsection{Objetivos}

A partir de uma análise setorial, pode-se caracterizar um determinado setor com base no seu desempenho, sobretudo o econômico, e compará-lo com o mesmo segmento em outras 
regiões ou países. Além disso, consegue-se distinguir as oportunidades, fraquezas e tendências. No presente trabalho, será realizada uma análise setorial da competitividade da viticultura, fundamentada na produtividade e seus aspectos tecnológicos e ambientais (institucionais e organizacionais). O principal objetivo do estudo é analisar a competitividade da viticultura brasileira. Além disso, tem-se como objetivos específicos:

- Identificar e caracterizar as principais regiões produtoras de uva de mesa do Brasil em relação a tamanho de propriedades, área total da região, predominância de produtores familiares, cooperativas ou de empresas viticultoras e variedades produzidas;

- Avaliar o nível tecnológico de cada região produtora de uva de mesa e identificar os fatores que levam às diferenças regionais.

- Investigar quais fatores do ambiente institucional afetam as organizações (produtores, cooperativas e empresas viticultoras) de cada região;

- Investigar qual região produtora brasileira é a mais competitiva no mercado interno/externo;

- Identificar os pontos fortes e fracos da viticultura brasileira;

- Investigar como está a competitividade do Brasil na viticultura frente aos concorrentes internacionais, avaliando os fatores que mais contribuem e impactam na competitividade.

\subsection{Problema de pesquisa}

$\mathrm{Na}$ viticultura brasileira, o Nordeste tem se destacado bastante nos últimos anos, tanto no mercado nacional quanto internacional. Por outro lado, no Sul e Sudeste, mais especificamente Paraná e São Paulo, boa parte dos produtores de uva de mesa fica a mercê de compradores e a concorrência exerce grande influência sobre a rentabilidade. Os compradores de uva de mesa dos produtores são atacadistas e supermercadistas. Os primeiros podem comprar em consignação e, muitas vezes, ocorre depreciação da fruta por conta da perda de qualidade durante o transporte, que acaba sendo repassada ao valor que seria recebido pelo produtor. 
É sabido que as condições edafoclimáticas de cada região também importam para a competitividade. Porém, com a tecnologia disponível, todas as regiões poderiam ser competitivas, de um modo geral.

Assim, quais são as diferenças que fazem com que uma região produtora do Brasil seja mais competitiva que outra? Quais são os fatores (regras institucionais - formais ou não) que moldam essas regiões produtoras e quais são as suas influências sobre o mercado? As diferenças culturais influenciam no ganho/adaptação de tecnologia entre as regiões? Os produtores familiares ou as grandes empresas tem melhor competitividade no setor da viticultura? Essas são algumas das perguntas que moldam o presente trabalho no que diz respeito à competitividade da viticultura brasileira.

Além disso, a uva é uma fruta importante para a balança comercial da fruticultura. $\mathrm{O}$ pico das exportações brasileiras de uva fresca de mesa ocorreu em 2008, quando o Brasil enviou pouco mais de 82 mil toneladas ao mercado internacional. Desde então, as exportações vem recuando ano a ano, chegando em 2013 com 43 mil toneladas comercializadas com outros países (MDIC/SECEX, 2014). Neste cenário, o que aconteceu no Brasil, nas regiões produtoras e nos países importadores, que reduziu em 47\% o volume das exportações brasileiras em apenas cinco anos? A produção brasileira tem sido competitiva frente aos concorrentes internacionais ou o mercado doméstico é que tem sido mais atrativo para a venda da fruta?

\subsection{Justificativa}

Frente a um mercado cada vez mais globalizado, ser competitivo com sustentabilidade tem sido prioridade para diversos setores e firmas. Competitividade sustentável pode ser descrita como um conjunto de técnicas e de conhecimento que visa o desenvolvimento promissor de diversas áreas de uma empresa/setor, como as áreas de gestão, as de pesquisa \& desenvolvimento (onde está inserida a tecnologia em si) e as de comercialização, distribuição e marketing (RECH, 2009), concomitantemente a realização de lucros positivos.

Para o agronegócio, a competitividade é dependente de fatores como a produtividade, o desempenho tecnológico no campo (relacionado à redução de custos ou diferenciação), além 
do ambiente institucional e organizacional. Esses dois últimos aspectos podem afetar a competitividade de um produtor e/ou de um setor a partir de regras, legislações, tributos, barreiras (não) tarifárias, ente outros.

Primeiramente, abordar-se-á a produtividade. Em muitos setores, o Brasil é criticado por ter baixa produtividade frente a outros países industrializados. Bloom et al. (2010) citam diversos fatores que levam países em desenvolvimento, inclusive o Brasil, a ter baixa produtividade - problemas com infraestrutura, informalidade, regulamentos, políticas comerciais e mão de obra, além de práticas gerenciais ruins, restrições financeiras e tomada de decisão.

Por outro lado, "o crescimento da produtividade tem sido o principal fator responsável pelo crescimento da agricultura nos últimos anos", argumentam Gasques, Bastos e Bacchi (2009, pg. 72). Ainda segundo estes autores, a agricultura brasileira foi impulsionada pelo ganho de produtividade de quatro fatores entre 1975 e 2007: mão de obra, capital, terra e a "mudança na composição do produto agropecuário". O primeiro diz respeito às melhorias da qualificação do trabalhador do campo. O segundo, o capital, está relacionado com o volume de recursos que tem sido oferecido ao agronegócio, por exemplo, através de crédito rural. $\mathrm{O}$ terceiro tem ocorrido por conta do aumento dos gastos com pesquisas no campo através de instituições públicas. Finalmente, o quarto significa que a agricultura tem crescido pela maior participação de produtos com valor agregado mais elevado, ou seja, produtos com maior remuneração relativa frente ao custo para a produção, como as frutas, que tem atributos percebidos pelos clientes, diferente de uma commodity, como a soja.

A fruticultura voltada para comercialização in natura, de modo geral, é dependente de bom volume de mão de obra, visto que algumas atividades ainda não são passíveis de mecanização total, como a colheita. Porém, muitos produtores de frutas no Brasil, inclusive viticultores, tem tido dificuldade para contratar e manter trabalhadores no campo por conta da migração destes para outras indústrias na cidade, sobretudo a construção civil. Tendo em vista a importância e consequente impacto da mão de obra, constata-se a necessidade de adoção ou adaptação de tecnologias de produção que demandem menos deste insumo tão importante.

O Brasil tem avançado na produtividade de uva (tanto de mesa quanto de indústria). Segundo dados oficiais da FAO (Organização das Nações Unidas para Agricultura e Alimentação), a produtividade nos parreirais brasileiros (média para uva de mesa e de indústria) cresceu $18 \%$ entre 2003 e 2012 (período de 10 anos). Já desde a década de 60, o rendimento médio nos campos de uva aumentou expressivos 164\% até o ano de 2012 (FAO, 2014). A hipótese para este aumento foi o melhor desenvolvimento genético e uso mais 
intensivo de irrigação, como no Vale do São Francisco, e implementos agrícolas. Apenas em relação à uva de mesa, a produtividade brasileira teve média, em 2012, de 21,7 toneladas/hectare (IBGE, 2014), abaixo de países como Chile e Itália, que tiverem rendimento médio de 22,1 t/ha e 22,3 t/ha, respectivamente, segundo dados de relatórios do Departamento de Agricultura dos Estados Unidos (USDA, 2014a).

Outro fator que pode tornar, ou não, um setor competitivo é o seu desempenho tecnológico, que, por sua vez, também está relacionado com a produtividade. Para Dosi (1982), a produtividade é uma proxy do progresso tecnológico. E na agricultura, tecnologia praticamente se traduz em ganhos de produtividade.

O melhoramento genético consiste na tecnologia mais importante para a cadeia produtiva das frutas, tendo em vista que novas cultivares resistentes a pragas, doenças e a climas mais severos podem auxiliar a competitividade nesse setor produtivo. "O Brasil tem tecnologia e conhecimento para avançar ainda mais no desenvolvimento de novas variedades de frutas, mesmo sendo esse um processo lento e exigente em recursos financeiros" (BRASIL, 2007, pg. 65). É claro que, em termos de tecnologia, não existe apenas o melhoramento genético, o País já avançou e deve continuar avançando em outras áreas, sobretudo em técnicas na pós-colheita, como embalagens, por exemplo (BRASIL, 2007). Neste sentido, ainda, para uva, e frutas in natura no geral, a qualidade e a variedade são fatores importantes no que diz respeito à competitividade, principalmente em relação aos lucros do produtor quanto melhor a qualidade percebida pelo comprador/consumidor, maior poderá ser o preço recebido pelo produtor.

Por fim, o ambiente importa. O ambiente institucional é formado por regras formais, constituições, leis e contratos, bem como regras informais, como as normas sociais. Se as instituições são as regras do jogo, as organizações e seus empresários são os jogadores. Organizações são compostas por grupos de indivíduos unidos por um propósito comum para atingir certos objetivos (NORTH, 1994). Organizações, neste trabalho, incluem agricultores (familiares ou não) e cooperativas. Para North (1991), o principal papel das instituições na sociedade é reduzir a incerteza, promovendo uma estrutura para o cotidiano do mercado. $\mathrm{O}$ mercado, por sua vez, oferece incentivos aos produtores, obrigando-os a suportar as consequências de suas decisões (MILGROM; ROBERTS, 1996). Para reduzir a incerteza nessas transações, devem-se observar as assimetrias de informação, que ocorre quando uma das partes envolvidas na negociação tem mais informações do que a outra, garantindo maior poder na transação (NORTH, 1994). 
As barreiras tarifárias e não tarifárias têm muita importância no que diz respeito ao ambiente institucional da fruticultura, sobretudo para aquelas que parte da renda é vinda de exportações, como no caso da uva. Um fator que diminuiu a competitividade do setor frutícola nas exportações para a União Europeia no início de 2014 foi que o Brasil já não faz mais parte do Sistema Geral de Preferências (SGP) nas questões tarifárias para produtos que entram no bloco europeu (Exporthelpdesk, 2014). O acesso a linhas de crédito e as tributações também são fatores importantes para o ambiente da fruticultura (BRASIL, 2007).

\subsection{Estrutura do trabalho}

O presente trabalho é uma análise setorial e comparativa sobre a competitividade do setor de uva de mesa do Brasil. Além desta introdução (Capítulo Um), que contem um panorama da viticultura, os objetivos, o problema de pesquisa e a justificativa do estudo, este documento é composto por mais quatro seções.

No Capítulo Dois consta a revisão teórica, na qual se discorre sobre a estrutura do mercado de uva e a competitividade, colocando como foco o agronegócio e os fatores que impactam no seu desempenho. No geral, ambiente institucional, tecnologia e produtividade são os principais fatores. Neste Capítulo também estão as hipóteses do trabalho, que são construídas com base no problema de pesquisa apresentado no Capítulo Um e na teoria apresentada nesta seção.

A terceira parte (Capítulo Três) é composta pela metodologia da dissertação. No presente trabalho é formulada uma triangulação da metodologia - análise documental (levantamento bibliográfico das legislações, normas, créditos agrícolas, entre outros para o setor de uva); análise estatísticas de dados secundários do Cepea/Esalq/Usp (avaliação da rentabilidade unitária ao produtor - preço x proxy de custo - e análise da evolução da produtividade das regiões de uva de mesa e compará-las) e de órgãos internacionais; e, por fim, a pesquisa qualitativa do presente trabalho (questionário aplicado a produtores de uva de mesa).

$\mathrm{Na}$ parte quatro do presente documento (Capítulo Quatro), estão a análise dos resultados e a discussão, que foram divididos em dois grandes grupos: competitividade 
regional e competitividade internacional. Nos resultados para as regiões produtoras do Brasil, estão detalhados o ambiente institucional, as entrevistas com produtores e os dados secundários de preço, produtividade e rentabilidade. No caso dos resultados internacionais, foram detalhados o ambiente institucional e os dados de produção, produtividade e preços de exportação para o Brasil, Chile e Itália.

Por fim, no Capítulo Cinco, estão as considerações, conclusões e limitações do presente trabalho. 


\section{Capítulo 2 - Revisão Bibliográfica}

\subsection{Estrutura de mercado}

O mercado é caracterizado por um conjunto de vendedores e compradores que interagem entre si, possibilitando de trocas. Um mercado que tem muitos compradores e vendedores, de modo que nenhum agente exerce forte pressão sobre os preços do mercado, pode ser chamado de concorrência perfeita. A maior parte dos mercados agropecuários, por exemplo, está próximo dessa estrutura de mercado (PYNDICK; RUBINFELD, 1994).

A concorrência perfeita, segundo Mansfield (1978),é definida por quatro condições. Primeiramente, os produtos são homogêneos, sendo que os preços são praticamente os mesmos, não diferindo aos consumidores. Em segundo lugar, os agentes (vendedores e compradores) devem ser tão pequenos que não possam afetar os preços, sendo estes definidos pelo mercado - oferta $x$ demanda. Terceiro, a mão de obra pode se deslocar de um lugar para outro e as matérias primas não devem ser monopolizadas, de forma que a firmas possam entrar ou sair do mercado livremente. Por fim, os vendedores têm conhecimento dos elementos tecnológicos e econômicos e os compradores, dos preços. A concorrência perfeita pressupõe, na teoria, que todas as unidades econômicas tenham conhecimento do futuro, passado e presente. É sabido, porém, que nenhum setor atende completamente todos esses requisitos (SAITONE; SEXTON, 2010), mas alguns mercados se aproximam de concorrência perfeita, como os da agricultura (MANSFIELD, 1978), no setor produtivo. Porém, nem todos os mercados tem essa mesma estrutura.

Além da concorrência perfeita, os economistas classificam as estruturas de mercado em mais três tipos: monopólio, concorrência monopolística e oligopólio. O monopólio é o oposto da concorrência perfeita. Nesta estrutura de mercado, há apenas um vendedor (uma única fonte de oferta) e vários compradores, de modo que esse vendedor tem controle sobre os preços do produto, impondo-os aos compradores. No monopólio, os exemplos são companhias de eletricidade, telefone, gás, etc. No geral, na concorrência perfeita, os vendedores são tomares de preços, enquanto que no monopólio, os vendedores são formadores de preços (Figura 3) (MANSFIELD, 1978; PYNDICK; RUBINFELD, 1994). 


\begin{tabular}{llll} 
& & \multicolumn{2}{c}{ Formadores de preços } \\
\hline $\begin{array}{l}\text { Concorrência } \\
\text { Perfeita }\end{array}$ & $\begin{array}{l}\text { Concorrência } \\
\text { monopolista }\end{array}$ & Oligopólio & Monopólio \\
$\stackrel{\text { Tomadores de preços }}{ }$ &
\end{tabular}

Figura 3: Estruturas de mercado

Fonte: Elaborado pela autora com base em Mansfield, 1978.

A concorrência perfeita e o monopólio mostram casos extremos. Assim, economistas sentiram necessidade de combiná-los para tratar casos mais frequentes na economia. Assim, surgiu a concorrência monopolística, que é caracterizada por vários vendedores, que tem produtos que apresentam diferenciação entre si, percebida pelos inúmeros compradores. Nesta estrutura, não há um produto único e homogêneo, como é no caso das commodities agrícolas. Os mercados varejistas são importantes exemplos da concorrência monopolística (MANSFIELD, 1978).

O oligopólio, por sua vez, é uma estrutura de mercado com poucas empresas, com certa interdependência. Com poucos vendedores, qualquer mudança no preço ou na oferta por parte de um deles afeta os lucros e as vendas dos concorrentes. A economia de escala é a principal razão para a existência do oligopólio. A estrutura oligopolista ainda pode ser classificada como: oligopólio puro, quando o produto é homogêneo; oligopólio diferenciado, quando existe diferenciação de produtos (MANSFIELD, 1978).

No setor de frutas, a estrutura predominante na produção rural é a concorrência perfeita, tendo em vista que a produção é homogênea - geralmente produtores plantam as mesmas variedades. Além disso, como principal fator, é o mercado que determina os preços os produtores de frutas são tomadores de preços.

\subsection{Competitividade}

A competitividade é uma palavra usualmente encontrada no vocabulário de empresas, empresários, administradores, políticos, dentre outros. Embora a competitividade seja um 
termo bastante relevante para o ambiente econômico de um país, muitos autores argumentam que é difícil conceituá-la e medi-la. Segundo Farina (1999), a competitividade não tem “definição precisa". Muitos autores concordam com esta posição (FERRAZ; KUPFER; HAGUENAUER, 1995; HARISSON; KENNEDY, 1997). Farina ainda argumenta que a "competitividade pode ser definida como a capacidade sustentável de sobreviver e, de preferência, crescer em mercados correntes ou em novos mercados. A sustentabilidade implica em que essa posição seja consistente com a realização de lucros não negativos" (Farina, 1999, p.149).

Para Da-Silva-Jr e colaboradores (2014), a sustentabilidade da competitividade é derivada de algumas vertentes, que devem ser alcançadas ao mesmo tempo. Porém, a falta de (a) soluções técnicas e gerenciais para reduzir custos e as barreiras culturais para os agricultores familiares e pequenas e médias empresas, (b) apoio à pesquisa e geração de conhecimento com disseminação de informações para toda a cadeia de produção e (c) conscientização de consumidores e detentores de poder governamental, podem limitar a competitividade sustentável da atividade agrícola.

Ferraz, Kupfer e Haguenauer (1995) também citam que é difícil encontrar metodologias adequadas para a mensuração da competitividade. Os autores ainda dividem o conceito de competitividade em duas vertentes: desempenho e eficiência. $\mathrm{Na}$ primeira, também chamada de competitividade revelada, é tomada por base a participação de mercado (Market share) tanto no mercado interno quanto na participação das exportações. Assim, essa vertente considera a demanda do mercado e a posição competitiva das empresas frente aos fatores comerciais. A segunda vertente, também denominada competitividade potencial, leva em consideração principalmente a relação insumo-produto (indicadores comparativos de preços $x$ custo, produtividade e coeficientes técnicos). Neste ponto, considera-se que o produtor é o principal responsável por seu desempenho, tomando por base sua capacitação tecnológica, gerencial, financeira e comercial. Por fim, para os autores, a competitividade é definida como "a capacidade da empresa formular e implementar estratégias concorrenciais, que lhe permitam ampliar ou conservar, de forma duradoura, uma posição sustentável no mercado" (FERRAZ; KUPFER; HAGUENAUER, 1995, p. 3).

Já Harrison e Kennedy (1997) alegam que a competitividade pode ter diferentes perspectivas, dependendo do enfoque e dos objetivos da pesquisa. Estes autores se baseiam em duas abordagens: a da gestão estratégica e a da economia neoclássica. Assim, definem competitividade como a habilidade de criar, de forma lucrativa, e agregar valor a produtos, com preços iguais ou inferiores aos oferecidos pelos concorrentes em um mercado específico. 
Os autores provêm uma análise teórica de que, para alcançar uma forte competitividade, o mais importante é reduzir os custos e/ou ter diferenciação, que impactam diretamente na rentabilidade e na parcela de mercado da firma (market share). Os autores citam, também, que, para ter vantagem neste cenário, a competitividade pode ser alcançada por meio de alguns fatores, como a adoção de novas tecnologias, que por sua vez afetam a produtividade da mão de obra e do capital. Além disso, os fatores externos podem afetar a competitividade de um dado setor, como políticas governamentais e variáveis macroeconômicas (Figura 4) (HARRISON; KENNEDY, 1997).

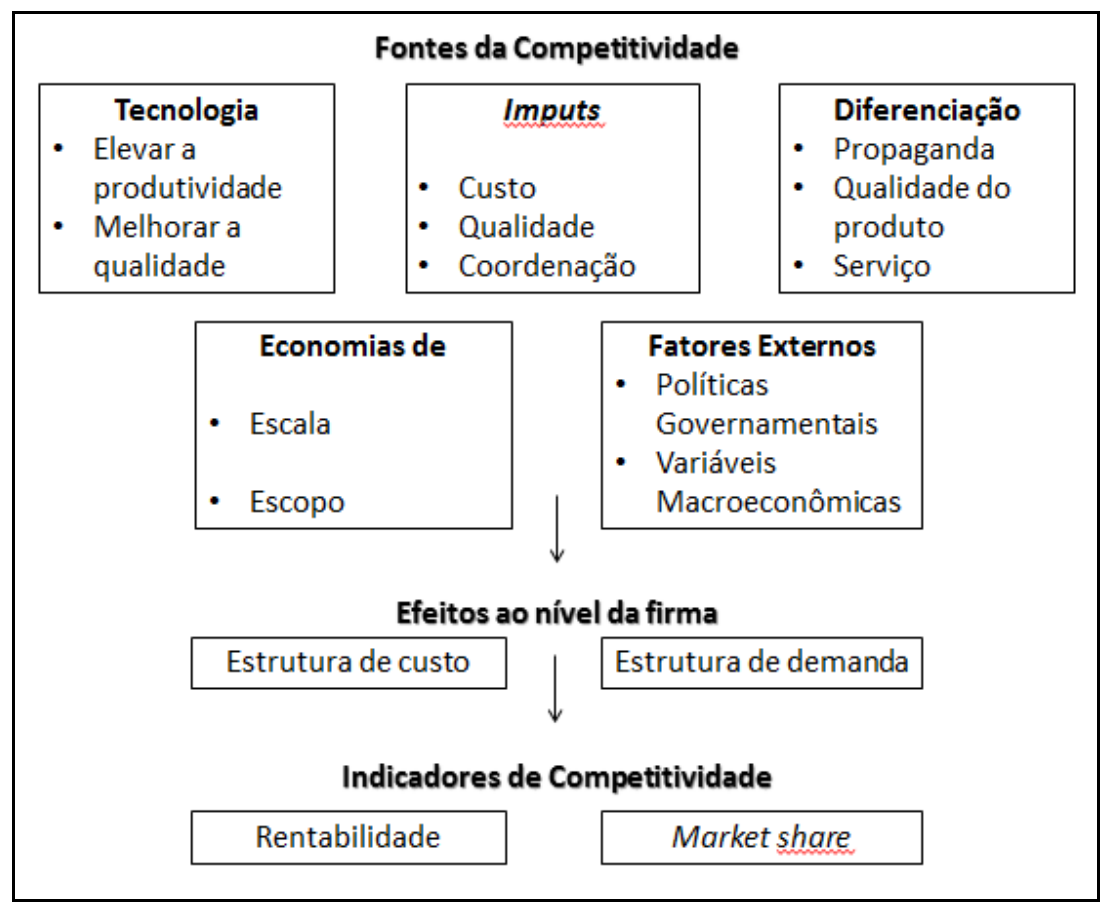

Figura 4. Fatores que influenciam a competitividade de setores do agronegócio

Fonte: Harrison e Kennedy (1997)

Kupfer (1992, p. 14) ressalta, porém, que a competitividade é

“um fenômeno 'ex-post' que, porém, não é captado pelo desempenho corrente da firma no mercado. O desempenho no mercado hoje está indicando a competitividade da empresa em algum momento do passado. (...). É disso que surge a mudança que permite que uma firma não competitiva torne-se competitiva e vice-versa, rompendo a tautologia expressa na associação de competitividade a variáveis ligadas ao desempenho corrente, como feito na abordagem convencional do tema".

Porter também aborda o tema competitividade, mais precisamente na forma de vantagem competitiva. Para Porter (1990), a competitividade é, e será cada vez mais, 
relacionada ao desempenho, sobretudo em grupo - o autor estuda a competitividade de redes, grupos ou regiões, e não de empresas isoladas, como os outros autores citados acima. Para se alcançar um desempenho superior, Porter acredita que as empresas devem seguir uma estratégia (PORTER, 1990; 1996). A estratégia de Porter (1996), nada mais é do que criar uma posição única e valiosa em um mercado, e sustentá-la. A sustentabilidade da competitividade já foi citada também por vários autores nesta revisão. Porém, a sustentabilidade da vantagem competitiva pode ser temporária, tendo em vista o mercado dinâmico e as tecnologias que surgem em rápida velocidade (PORTER, 1996).

Além disso, Porter (1990) aborda dois pontos importantes da vantagem competitiva em seu livro Vantagem Competitiva: vantagem de custo e diferenciação. A vantagem de custo nada mais é do que ter custo de produção para um determinado produto mais baixo que o do seu concorrente. Porter descreve algumas técnicas para se obter essa vantagem, mas ressalta que não substitui totalmente a análise detalhada dos custos. Quanto à diferenciação, provém da criação singular de valor para um comprador. Saitone e Sexton (2010) estudaram sobre diferenciação nos mercados agrícolas, relacionando com a qualidade. Para eles, um consumidor percebe a atributos diferentes nos alimentos, valorizando-os. Dependendo da característica em questão, rotulagem e certificação, por exemplo, são mecanismos potenciais para as empresas fornecerem informações sobre os atributos aos consumidores, diferenciandoos dos demais no mercado. Embora a diferenciação de produtos possa ser a chave para o sucesso no mercado de alimentos, existem barreiras para atingir esses resultados. Além de estabelecer a credibilidade dos atributos diferenciadores, muitas vezes há custos fixos substanciais que podem estar além do alcance dos produtores individuais ou mesmo grupos de produtores. Além disso, a diferenciação de produtos quanto à qualidade, pode levar à ruptura de que o mercado agrícola é caracterizado por concorrência perfeita.

Ainda no caso de produtos agrícolas, a qualidade pode ser um aspecto de diferenciação, pode ser um ativo específico. Farina e Zylbersztajn (1991) citaram que investimentos em diferenciação por qualidade podem motivar os consumidores a adquirir tais produtos e exigir qualidade semelhante dos concorrentes que não tem diferenciação por qualidade. Vale lembrar que qualidade de um produto agrícola é determinada, pelo menos em parte, pela natureza, através das condições e variações de temperatura, luz solar, precipitações, solo e clima, além das taxas de infestação de pragas (SAITONE; SEXTON, 2010).

Para se medir a vantagem competitiva, Porter (1993) recomenda o "Diamante de Porter" (Figura 5). O autor construiu o diamante para analisar setores econômicos de um país 
- o da uva de mesa no Brasil pode ser considerado um setor passível de se utilizar esse método. O diamante é composto por quatro atributos: (1) condições de fatores: a posição em relação aos fatores de produção, como mão de obra qualificada e infraestrutura. Os mais importantes fatores são aqueles que envolvem pesados investimentos e que exigem especialização; (2) condições de demanda: a demanda do mercado interno para os produtos do setor. A composição e a natureza do mercado doméstico afetam diretamente na competitividade; (3) setores correlatos de apoio: a presença (ou ausência) de fornecedores, e outros correlatos, competitivos. Isso porque podem oferecer insumos com maior eficácia e menor custo; (4) estratégia, estrutura e rivalidade das empresas: as condições que determinam o gerenciamento, bem como, a natureza da rivalidade no mercado interno. Aqui, a competitividade decorre da convergência de práticas gerenciais (PORTER, 1993).

Além destes, o governo e o acaso, poderiam ser mais dois atributos. $\mathrm{O}$ primeiro pode ser um auxiliar ou promotor, de maneira que as políticas contribuem para o desempenho da competitividade. O segundo está relacionado aos fenômenos da natureza, ou fatores geopolíticos (como o terrorismo) (PORTER, 1993). O autor ainda considera o "Diamante" como um sistema - os atributos, juntos, podem mover a competitividade de um dado setor. Se um dos atributos vai mal, provavelmente freará o potencial de desenvolvimento do setor.

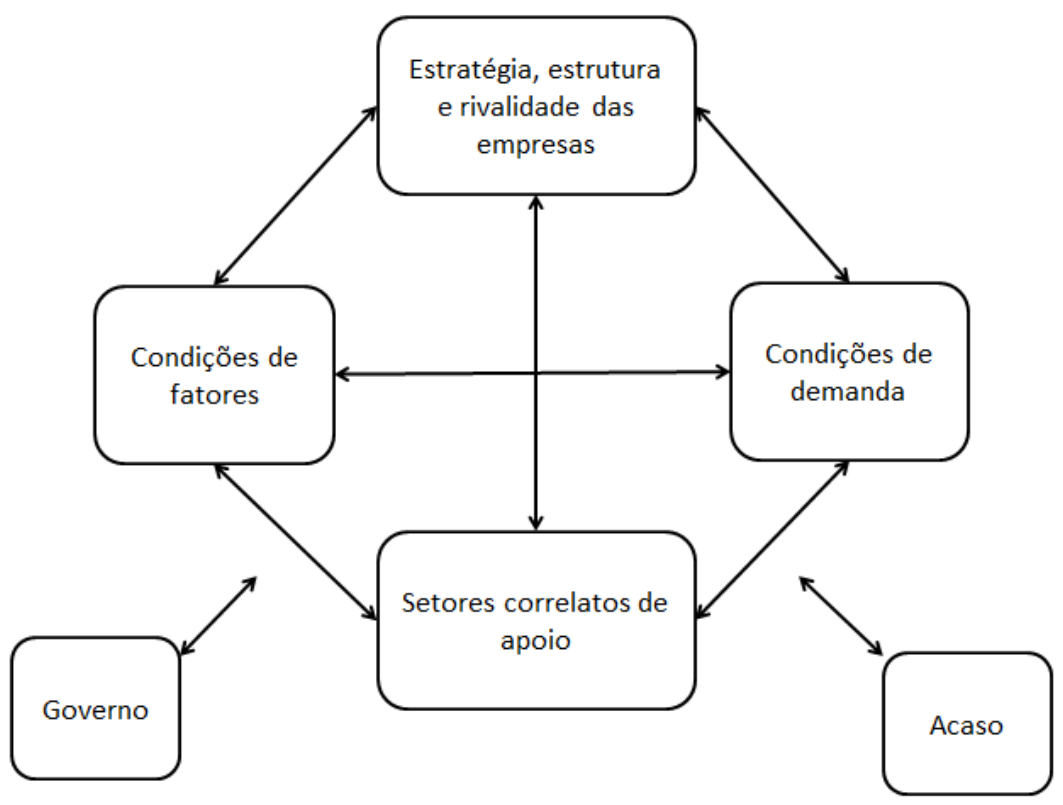

Figura 5. O modelo do "Diamante de Porter" para a competitividade Fonte: PORTER (1993). 
Porter (2008) ainda aborda as cinco forças competitivas (Figura 6). Para o autor, compreender as forças competitivas, e as suas causas, revela as raízes da rentabilidade, proporcionando uma estrutura para antecipar e influenciar a concorrência (e lucratividade) ao longo do tempo. Entender as forças que moldam a competitividade também é essencial para um posicionamento estratégico eficaz. As cinco forças de Porter são:

1. Ameaça de novos entrantes: novos entrantes em um mercado trazem mais capacidade e vontade de ganhar parcela desse mercado. Eles tendem a diversificar e a usar os recursos existentes e fluxos de caixa para abalar os concorrentes. A ameaça de entrada coloca um limite sobre o potencial de lucro de um setor. Quando a ameaça é alta, os preços devem se manter ou o investimento deve aumentar para impedir novos concorrentes. As barreiras à entrada são importantes para esta força competitiva;

2. Poder de barganha dos fornecedores: os fornecedores podem capturar mais valor (da cadeia) para eles através da cobrança de preços mais altos, limitando a qualidade ou serviços, ou transferindo os custos para os participantes do setor. Os fornecedores mais poderosos, sobretudo os de mão de obra, podem, assim, reduzir a rentabilidade de um setor. Um fornecedor é poderoso quando não depende de poucos compradores para garantir suas vendas, fazem parte de um mercado mais concentrado que o dos seus clientes, oferecem produtos diferenciados, entre outros;

3. Poder de barganha dos compradores: o cliente pode capturar mais valor ao forçar os preços para baixo, exigindo melhor qualidade ou mais serviços (aumentando assim os custos), e geralmente jogando os fornecedores uns contra os outros, às custas da rentabilidade. Os compradores são poderosos se eles têm poder de negociação em relação aos participantes do setor, especialmente se eles são sensíveis ao preço. Um grupo de clientes tem poder de negociação se existem poucos compradores, se os produtos são padronizados, se podem integrar à montante (ou seja, para trás), entre outros;

4. Ameaça de produtos e serviços substitutos: um substituto executa a mesma ou similar função de um produto - por exemplo, carne de frango $x$ carne bovina. Substitutos estão sempre presentes, porém, por vezes, são fáceis de ignorar, porque podem parecer muito diferentes. Quando a ameaça de substitutos é alta, a rentabilidade reduz. Produtos ou serviços substitutos limitam o potencial de lucro, colocando um teto sobre os preços. Se uma indústria não se distanciar dos 
substitutos por meio do desempenho de produtos, marketing, ou outros meios, terá menor rentabilidade, e muitas vezes, redução do potencial de crescimento;

5. Rivalidade entre os concorrentes: rivalidade entre concorrentes existentes assume muitas formas, incluindo descontos de preço, introdução de novos produtos, campanhas publicitárias e melhorias no serviço. Alta rivalidade limita a rentabilidade. A intensidade da rivalidade é maior se os concorrentes são numerosos, o crescimento do setor é lento, se as barreiras à saída são grandes, há forte concorrência de preços, entre outros (PORTER, 2008).

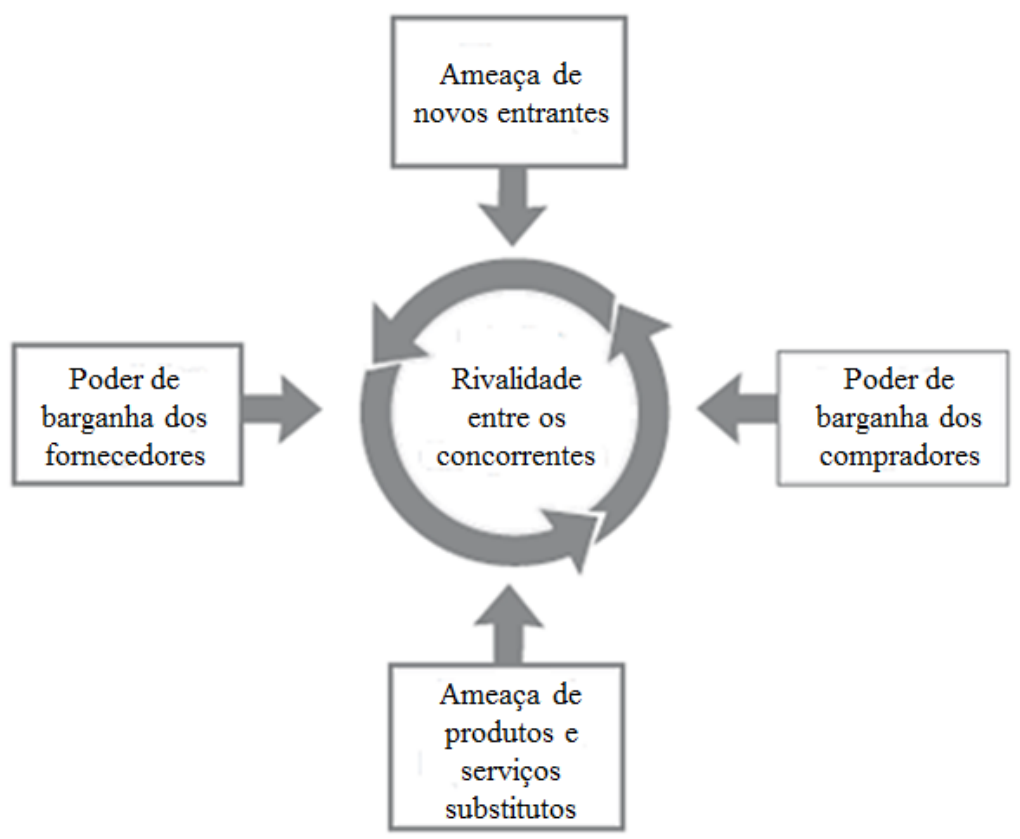

Figura 6. As cinco forças competitivas de Porter.

Fonte: PORTER (2008)

Porter (2008) ainda salienta que a configuração das cinco forças pode diferir em cada setor. As cinco forças de Porter são bastante usadas para reforçar análises de competitividade e/ou vantagem competitiva em vários setores. No agronegócio, Eyler (1999), utilizou as cinco forças de Porter em sua análise da competitividade do setor de vinhos da Califórnia, nos Estados Unidos. Concomitante a um modelo estatístico de demanda, que descreve os possíveis fatores de diferenciação do vinho dos EUA frente aos vinhos chilenos, o autor fez uma relação com as cinco forças para sustentar a análise de competitividade.

Indo de encontro a Porter e complementando as teorias sobre competitividade, surgiu a Visão Baseada em Recursos (VBR). A VBR tem foco em recursos e não em produto 
(WERNERFELT, 1984) e pressupõe que os recursos (que variam de empresa a empresa) são fundamentais para a estratégia, e que deve haver uma capacidade de controlar esses recursos, sobretudo os valiosos, raros, imperfeitamente imitáveis e insubstituíveis, para se obter vantagem competitiva frente aos concorrentes (BARNEY, 1991). A capacidade das firmas, para a VBR, é muito importante. Para Barney (2001), a VBR, em sua forma neoclássica, pode ser apropriada para o estudo de rendas geradas pela habilidade de desenvolver novas capacidades das firmas. Porém, diferentemente da economia neoclássica, a VBR adota o pressuposto de que, em geral, recursos e capacidades tem oferta elástica (fatores de produção não o teriam) (BARNEY, 2001). Porém, nem sempre, a inelasticidade é tangível ou facilmente dedutível. No agronegócio, Saes (2008), também considera a inelasticidade na teoria de VBR e cita, como exemplo, o caso da mão de obra agropecuária, que embora não seja inelástica, "a criatividade e a habilidade o são". E a autora ainda complementa que uma propriedade agrícola, "mesmo inserida em um mercado concorrencial, pode se diferenciar ao se beneficiar de recursos naturais únicos (fonte de água, por exemplo) ou mesmo de um aprendizado particular" (SAES, 2008, p.27). Assim, os recursos e capacidades, no mercado do agronegócio, e neste caso, na uva, podem variar entre regiões produtoras ou, até mesmo, entre as propriedades inseridas em uma mesma regionalidade.

Mais estudos recentes sobre competitividade no agronegócio também têm surgido nos últimos anos. Ball e colaboradores (2010), por exemplo, estudaram empiricamente a competitividade da agricultura dos Estados Unidos frente à de 11 países da União Europeia. Para os autores, o conceito mais intuitivo de competitividade, sobretudo a internacional, é o da competitividade dos preços de mercado - aqueles que detêm o menor preço, provavelmente são os que têm menor custo. Ball et al.(2010) levaram em consideração, ainda, para medir a competitividade, a taxa de câmbio e o aumento relativo da produtividade da agricultura. Como conclusão, as comparações internacionais de preços mostram que os Estados Unidos foram mais competitivos do que a União Europeia ao longo do período 19732002, exceto para os anos de 1973-1974 e 1983-1985. Os resultados também sugerem que o nível de produtividade relativa foi o fator mais importante na determinação da competitividade internacional. Durante os períodos de 1979-1984 e 1996-2001, o fortalecimento do dólar ajudou os países europeus a melhorar sua posição competitiva, assim como o desempenho de produtividade.

Padilla-Bernal et al., (2010) estudaram o setor de tomate fresco produzido em estufas em Zacatecas, no México, onde a produção tem aumentado ano a ano. Foi aplicado um modelo de competitividade sistêmica, que é a determinação da posição competitiva dentro de 
um cenário globalizado. A análise englobou o nível microeconômico, mesoeconômico ${ }^{10}$, macroeconômico, internacional, institucional e sociopolítico. As informações utilizadas foram baseadas em entrevistas. Índices de competitividade também foram obtidos através do agrupamento de empresas pelo mercado onde vendem seus tomates, nacionais ou internacionais, e por nível de tecnologia, para a qual foi aplicada a técnica de análise de cluster. Os autores concluíram que o índice de competitividade sistêmica do setor de produção de tomate fresco em estufas de Zacatecas foi $50 \%$ menor do que o índice de competitividade potencial. Esta situação sugere necessidade de melhorar a produtividade, aprendizagem organizacional, desenvolvimento tecnológico e grau de satisfação dos clientes.

No Brasil, Mattei e Triches (2009), analisaram a competitividade da cadeia produtiva vitivinícola gaúcha - uva para suco e vinho -, tomando por base a configuração do ambiente institucional. Como conclusão, os autores relataram que o ambiente institucional tem "papel duplo" no que diz respeito à competitividade, ou seja, ao mesmo tempo em que possibilita o desenvolvimento da cadeia, limita o alcance do que está sendo buscado. Os autores destacam que o "aprimoramento mercadológico, tecnológico, de governança e nas estratégias empresariais é bem superior nos segmentos ligados à produção de vinhos finos e espumantes (esses enfrentam forte concorrência externa), comparativamente à produção de vinhos comuns e outros derivados, cuja concorrência está fortemente atrelada às condições do mercado interno" (MATTEI; TRICHES, 2009, p. 180).

\subsection{O ambiente institucional e as organizações}

Se as instituições são as regras do jogo, as organizações e seus empresários são os jogadores (NORTH; 1991,1994). Organizações são compostas por grupos de indivíduos unidos por um propósito comum para atingir certos objetivos (NORTH, 1994). Organizações, no presente trabalho, incluem produtores de uva de mesa (familiares ou não) e cooperativas. A análise do ambiente institucional é importante para se entender as instituições (regras do jogo) e como estas têm afetado o mercado e seus agentes. A principal contribuição do ambiente institucional, por sua vez, tem sido a relação entre as instituições e o

\footnotetext{
${ }^{10}$ Mesoeconomia é um nível intermediário entre a macroeconomia e a microeconomia. A mesoeconomia procura entender como as mudanças em um ambiente empresarial podem afetar a economia e a realidade da empresa envolvida. A mesoeconomia estuda preços e produtividade, sempre com foco no social (BÊRNI; LAUTERT, 2011).
} 
desenvolvimento da economia, sendo que um dos papéis das instituições é investigar os efeitos no resultado econômico (AZEVEDO, 1997).

Para North (1991), o principal papel das instituições na sociedade é reduzir a incerteza, estabelecendo uma estrutura estável entre as interações humanas (não necessariamente eficientes).

Belik, Reydon e Sebastião-Neto (2007) estudaram as instituições em quatro níveis: "embeddedness", ambiente institucional, governança (ou custos de transação) e economia neoclássica. A primeira é bastante estudada na história econômica e na sociologia e leva em consideração as instituições mais estáveis e formais, como religião e o Estado, e informais, como tradições e costumes (BELIK; REYDON; SEBASTIÃO-NETO, 2007). Para North (1993), a história demonstra que as ideias, ideologias, mitos, dogmas e preconceitos importam, e uma melhor compreensão da evolução é necessária para compreender o desenvolvimento da mudança social. Crenças se transformam em estruturas sociais e econômicas por instituições (tanto pelas regras formais quanto por normas informais de comportamento) (NORTH, 1993). Já a segunda, principal objeto de estudo do presente trabalho, toma por base as regras formais que medem as relações entre os agentes. O ambiente institucional analisa as mudanças na legislação, no sistema judiciário, na burocracia governamental e, ainda, nos direitos de propriedade (BELIK; REYDON; SEBASTIÃONETO, 2007). A terceira está relacionada com as transações econômicas. Neste caso, as instituições buscam reduzir os custos de transação. Coase e Williamson desenvolverem muitos trabalhos ricos nesta área. O último nível, da economia neoclássica, foca nos custos de produção de bens e serviços. É aqui que estão as relações econômicas de preços, compra e venda e, também, as questões de qualidade (BELIK; REYDON; SEBASTIÃO-NETO, 2007).

Já Azevedo (2000) divide as instituições em dois pontos, mas ainda bastante relacionadas com a de Belik, Reydon e Sebastião-Neto. O primeiro é o microanalítico, que regula transações entre as partes. As regras são decisivas para a competitividade dos participantes de um determinado grupo de produtores, no caso do agronegócio, por permitir maior coordenação do sistema. O segundo ponto é o do ambiente institucional, que se assemelha com os dois primeiros níveis destacados por Belik, Reydon e Sebastião-Neto (2007). Para Azevedo (2000), esse ponto também pode ser chamado de macroinstituições, especialmente importante para o agronegócio por conta três fatores: "a) regras formais (políticas agrícolas e regulamentação); b) regras informais (códigos de ética, laços familiares, valores culturais e étnicos);" além de destacar os "direitos de propriedade da terra" (que podem ser inseridos tanto em regras formais quanto informais) (AZEVEDO, 2000, p. 35). 
a) As regras formais como já destacado por North (1990) são as leis da sociedade. Azevedo (2000) ainda cita a constituição e o conjunto de políticas públicas como importantes no agronegócio - nesta última, ainda, se encaixam políticas agrícolas e de reforma agrária. Essas regras tem papel fundamental nas decisões e investimentos de longo prazo por parte dos agentes, neste caso, de produtores rurais. Por outro lado, se as regras forem instáveis, pode causar incerteza (NORTH, 1994), reduzindo os investimentos (AZEVEDO, 2000).

b) As regras informais foram destacadas por North (1990). Para este autor, são originadas na cultura de sociedades menos complexas e são retransmitidas entre as gerações. Belik, Reydon e Senastião-Neto (2007) abordaram também este ponto. Para Azevedo (2000), um tópico interessante é que essas regras não podem ser manipuladas, tendo em vista que não são escritas nem explícitas. Essas instituições podem, ainda, reduzir custos de coordenação por permitir fácil interação entre os agentes (AZEVEDO, 2000).

Os direitos de propriedade da terra (formais e informais) são muito explorados nos trabalhos de Harold Demsetz. Segundo Demsetz (1967), os direitos de propriedade são um instrumento da sociedade. Sua importância deriva do fato de que ajudam um indivíduo a formar expectativas nas relações com os outros. Essas expectativas encontram expressão nas leis, costumes e atitudes de uma sociedade. Para Azevedo (2000), os direitos de propriedade da terra podem ter importantes impactos econômicos, tendo em vista que alguns problemas podem reduzir investimentos, sobretudo em lavouras permanentes (como a uva), que tem maior probabilidade de expropriação em relação às lavouras temporárias.

E como as instituições afetam o mercado e seus agentes? O mercado está em constante mudança no contexto da globalização. Mudança econômica é um processo onipresente, contínuo e incremental que é consequência das escolhas que os agentes das organizações fazem todos os dias (NORTH, 1993). O mercado, para Buainain (2007), é a principal forma que baseia as decisões dos produtores. Ainda segundo este autor, "no mundo real, o mercado é uma instituição imperfeita, sujeita a falhas e ao mau funcionamento" (BUAINAIN, 2007; p. $55)$.

Em algumas situações o governo pode interferir eficientemente no mercado, porém, na maioria das vezes, experiências históricas detalharam que o Estado é impotente e que as intervenções podem produzir mais falhas (BUAINAIN, 2007). Não é que os governantes tenham tido mau desempenho, é que a dificuldade de transformar as economias ao redor é uma função da natureza dos mercados e políticas (NORTH, 1993). 
O mercado, ainda, oferece incentivos aos produtores, porém, a partir deste podem surgir algumas consequências (MILGROM; ROBERTS, 1996). Estes problemas são agravados quando assimetrias de informação estão presentes, antes ou após as transações (MILGROM; ROBERTS, 1996). Para Cook e Chaddad (2000), os arranjos em um ambiente institucional são projetados para substituir os mercados ausentes ou surgem como uma resposta à informação imperfeita em mercados competitivos do agronegócio.

As instituições do mercado se projetam para induzir os agentes a adquirir as informações essenciais que vão levá-los a corrigir seus modelos, principalmente quando existem custos de transação significativos. Porém, os agentes normalmente têm informações incompletas (NORTH, 1993), sobretudo em mercados com baixo custo de transação.

Segundo Azevedo (2000), há diversos estudos incluindo instituições como tema principal, porém, não há uma abordagem única. Ainda de acordo com este autor, "tem sido crescente o interesse pelo estudo das instituições em trabalhos sobre a organização da atividade agrícola e seu desempenho" (AZEVEDO; 2000, pg. 34). Alguns estudos mais recentes elucidam como as instituições ainda são pauta e tem afetado o cenário do agronegócio no Brasil e no mundo.

No Brasil, Nogueira e Zylbersztajn (s/d), estudaram a coexistência de arranjos institucionais, sobretudo o papel dos contratos e das transações de mercado, no setor de avicultura de corte no estado de São Paulo, mais especificamente em 30 processadores. Os autores buscaram as respostas do porque coexistem diversos arranjos (via mercado, contratos de fornecimento, contratos de parceria e integração vertical) neste setor. Além dos arranjos institucionais, os autores encontraram o perfil dos fornecedores de aves e identificaram as transações de mercado. As principais transações (médias) foram contratos de parceria (33\%), de fornecimento (27\%), integração vertical $(25 \%)$ e via mercado $(11 \%)$. Dentre as hipóteses de transação de mercado, ainda, foi considerado o fator da tecnologia - para este quesito, quanto maior a mudança no nível tecnológico percebida do fornecedor que transaciona via mercado, menor a participação dos contratos e da integração.

O ambiente institucional também já foi estudado em relação ao crédito agrícola. Almeida e Zylbersztajn (2008) estudaram as principais mudanças ocorridas no ambiente institucional no financiamento agrícola no Brasil e seus impactos para o setor da soja. Um grande problema no mercado de crédito agrícola são os riscos associados às negociações e a insegurança por parte dos agentes. Os autores concluíram que este cenário melhorou até o ano do estudo, diminuindo a incerteza nas transações por conta do maior uso dos contratos, 
atraindo até mesmo investidores nacionais e internacionais (ALMEIDA; ZYLBERSZTAJN, 2008).

Olsson e Svensson (2010) estudaram o crescimento da agricultura na União Europeia, sobretudo da Suécia, para verificar os efeitos de mudanças institucionais, simultaneamente com a comercialização, a fim de entender, na história, os fatores importantes por trás do crescimento entre os anos de 1700 e 1860 . No período, a produtividade no campo aumentou substancialmente, sobretudo para atender a grande demanda interna de alimentos. Como conclusão, as mudanças nos direitos de propriedade impactaram bastante: quando o produtor era dono da terra, ele investia mais e produzia mais frente àquele que arrendava a terra. Ao mesmo tempo, a liberalização do comércio contribuiu para o crescimento, e os produtores reagiram aos incentivos, aumentando a produção.

\subsection{Tecnologia e produtividade}

No mundo dos negócios, a tecnologia é um fator imprescindível para o bom desempenho da competitividade. Para Feldmann (2009), "as empresas que são bem-sucedidas são as que conseguem usar bem as novas tecnologias, e, de preferência, antes que seus concorrentes o façam” (FELDMANN, 2009, p. 120). Dicken, em 2010, também ressaltou que, para garantir a sustentabilidade competitiva, uma empresa deve adotar as mesmas tecnologias que um concorrente começou a utilizar. Para este autor, ainda, a escolha da melhor tecnologia estará sempre relacionada com a "busca de lucros, acúmulo de capital e investimento, aumento da fatia de mercado, etc.” (DICKEN, 2010, p. 91).

Adotar novas tecnologias, porém, é custoso. Historicamente, o valor pago pela adoção da tecnologia vem recuando a cada década, mas ainda pesa no orçamento das empresas e dos setores. Ao mesmo tempo, a eficiência da produção (ou produtividade) vem aumentando - a cada nova tecnologia utilizada com frequência, as taxas de crescimento da produtividade aumentam devido à curva de aprendizagem, mostrando uma possível interação entre esses dois fatores. Contudo, na fase inicial, as novas tecnologias podem operar de forma ineficiente devido às inexperiências quanto ao seu uso - operar novas tecnologias muitas vezes envolve, além da aquisição, processamento de novas informações (GREENWOOD, 1999). 
Tecnologia, para Giovanni Dosi (1982), em seu memorável artigo sobre paradigmas tecnológicos, é um conjunto de conhecimento, tanto prático quanto teórico (aplicável) - knowhow, métodos, procedimentos e experiência de sucessos e fracassos. Tecnologia, nessa visão, inclui a percepção de um conjunto limitado de possíveis alternativas e de futuros desenvolvimentos. Dosi (1982) ainda classificou as mudanças tecnológicas em duas grandes categorias, consideradas recentes na literatura e nas pesquisas, e nomeadas de "demanda pull" e "'tecnologia push“. A primeira aponta para as forças de mercado como os principais determinantes da mudança tecnológica, ou seja, são feitas inovações a partir da demanda dos consumidores. A segunda define que as mudanças tecnológicas são determinadas pela área de Pesquisa e Desenvolvimento (P\&D), produção ou vendas, sem considerar as demandas do consumidor. Cada qual com suas particularidades têm pontos positivos e negativos.

Já para Peter Dicken (2010), a mudança tecnológica é um processo social e institucionalmente incorporado, sendo que a utilização de tecnologias está condicionada pelo contexto socioeconômico. A mudança tecnológica é também uma forma de aprender e Dicken (2010) cita quatro tipos gerais dessa mudança:

a. Inovações incrementais: são aquelas pequenas e progressivas, feitas em produtos/processos que já existem. Geralmente se acumulam com o tempo, gerando mudanças significativas;

b. Inovações radicais: são alterações mais drásticas nos produtos/processos existentes.

c. Mudanças do sistema tecnológico: são mudanças na tecnologia mais abrangentes e que afetam a economia. Geralmente estão associadas com o surgimento de tecnologias genéricas - como a biotecnologia;

d. Mudanças no paradigma tecnoeconômico: são mudanças em grande escala e revolucionárias. Essas mudanças mudam a produção e o gerenciamento de tal forma que impactam fortemente na economia (DICKEN, 2010).

Este autor ainda acredita que a tecnologia não é independente, mas sim um agente facilitador, que viabiliza "novas estruturas, novos arranjos organizacionais e geográficos das atividades econômicas, novos produtos e novos processos” (DICKEN, 2010, p. 92).

A tecnologia está presente na cadeia de valores das empresas, podendo gerar vantagem competitiva (PORTER, 1990). Para Porter (1990), “um grande desenvolvimento tecnológico não precisa envolver rupturas científicas, nem mesmo tecnologia que antes não estavam amplamente disponíveis" (PORTER, 1990, p. 159). Por vezes, ainda, um desenvolvimento tecnológico diminui o custo das operações de mercado, ao mesmo tempo em que se expande o 
papel da empresa (ALCHIAN; DEMSETZ, 1972). Vale ressaltar, porém, que isso nem sempre acontece - às vezes uma indústria com alto gasto em tecnologia tem menores ganhos do que uma de baixa tecnologia (PORTER, 1990).

Além disso, o crescimento da produtividade pode ser mais lento quando o investimento (imensurável) no conhecimento total das novas tecnologias implantadas está se aproximando do seu pleno potencial (GREENWOOD, 1999).

No Brasil, a tecnologia foi um dos fatores que auxiliou para o avanço de muitas culturas do agronegócio, sendo um fator decisivo no sucesso (GASQUES et al., 2004; FELEMA; RAIHER; FERREIRA, 2013).Um exemplo prático na fruticultura, objeto de estudo deste trabalho, é o caso da maçã. Segundo Fioravanço (2009), o uso de tecnologias na produção dessa fruta foi o fator decisivo para o sucesso da produção e conquista do mercado interno, e posteriormente, o externo. O uso de cultivares adaptadas ao clima brasileiro, melhoramento genético, uso de produtos químicos e capacidade frigorífica são os principais fatores tecnológicos da pomicultura.

Diante deste exemplo e de muitos outros, vários autores e estudiosos do agribusiness concordam que tecnologia na agricultura praticamente se traduz em ganhos de produtividade. As primeiras formas de inovação tecnológica no campo surgiram a partir de estudos de instituições privadas, com o desenvolvimento de sementes melhoradas, as chamadas Variedades de Alta Produtividade (VAP). Isso ocorreu um pouco antes da Revolução Verde, que ocorreu nas décadas de 1960 e 1970. Findada a II Guerra Mundial, as indústrias químicas incentivaram o uso de defensivos e fertilizantes sintéticos no campo, além das máquinas (tratores, por exemplo), sementes geneticamente melhoradas e irrigação. Apesar de todas as críticas inerentes à Revolução Verde (em relação a problemas ambientais, sociais e políticos), esta foi o marco da tecnologia na agricultura (ROSA, 1998; ALBERGONI; PELAEZ, 2007; DICKEN, 2010).

A Revolução Verde foi uma precursora da modificação genética - a biotecnologia é uma tecnologia bastante importante para a produção de alimentos, de modo que manipula geneticamente seres vivos para fins econômicos. O objetivo desta tecnologia para a agricultura é, principalmente, elevar a produtividade no campo e melhorar a qualidade, aumentando a resistência da planta a pragas, doenças e defensivos químicos e, também, às mudanças climáticas (SILVEIRA; BORGES; BUAINAIN, 2005; DICKEN, 2010).

$\mathrm{Na}$ agricultura, a biotecnologia gerou, ainda, os cultivares transgênicos, que insere nas variedades tradicionais genes que conferem características agronômicas desejáveis. O uso de 
transgênicos é crescente no Brasil (Figura 7) e no mundo, sobretudo nas grandes culturas soja, milho, etc. (CARRER; BARBOSA, RAMIRO, 2010).

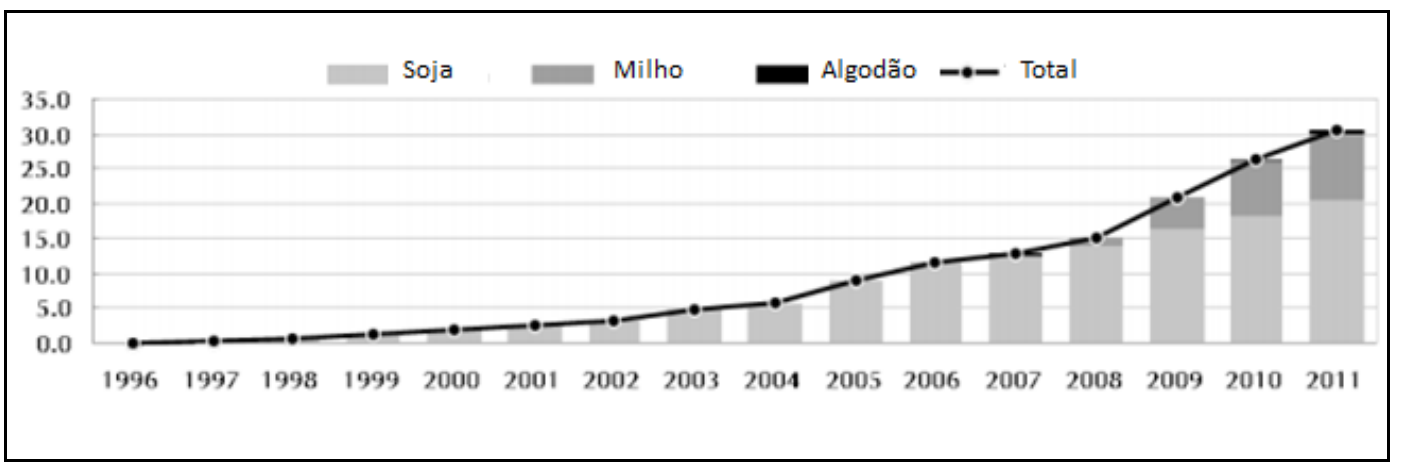

Figura 7. Evolução da área (em milhões de hectares) com cultivares transgênicos no Brasil Fonte: James (2011) elaborado com base em CÉLERES ${ }^{\circledR}$ Consultoria (2011)

Para a fruticultura, por outro lado, ainda há apenas experimentos, tendo em vista que o consumidor é mais relutante em adquirir produtos transgênicos para consumo in natura - os grãos geneticamente modificados, por exemplo, são processados antes de ser consumidor por humanos. Em 2013, a Comissão Técnica Nacional de Biossegurança (CTNBio) liberou o cultivo de laranjeiras transgênicas para pesquisa. A CTNBio autorizou o ciclo completo de laranjeiras transgênicas - até então eram proibidos o florescimento e a frutificação. Já foram plantadas 650 mudas transgênicas em Ibaté (SP) que devem produzir em meados de 2016. Especialistas acreditam que essas árvores sejam resistentes à pinta-preta e ao cancro-cítrico (Fundecitrus, 2014).

Outra tecnologia que auxiliou no aumento da produtividade ao longo dos anos e ainda continua neste rumo é o maior uso de defensivos no campo - o setor de defensivos faz parte da indústria de química fina, que possui alto valor unitário. Segundo Frenkel e colaboradores (1996), o grau de eficácia no combate a pragas e doenças pelos defensivos influencia no aumento da produtividade final, sendo uma opção tecnológica para o produtor. Além disso, a eficácia está associada ao tipo de solo, condições de aplicabilidade, tipos de sementes, condições de clima durante o período produtivo, entre outros.

O maior uso de tecnologias de máquinas, implementos agrícolas e irrigação também impulsionam a produtividade da agricultura (VIEIRA-FILHO, 2009; GRAY; JACKSON; ZHAO, 2011). Para o setor de grãos, por exemplo, havia necessidade de mecanização para se ganhar competitividade internacional e diminuir o uso de mão de obra humana, onerosa e, por vezes, má qualificada. Nogueira (2001), estudando o uso de máquinas e a evolução da 
agricultura, encontrou correlação positiva da quantidade de tratores em uso com o PIB, renda per capita, produção, área colhida de cereais e população urbana, com amostra de 136 países. Dados da Anfavea (2014) mostram que as vendas de colhedeiras de grãos no Brasil iniciou em 1976. Comparando as colhedeiras vendidas em 1976 com as de 2013, as vendas aumentaram $61 \%$, ao passo que a produtividade média da soja no Brasil saltou $68 \%$ (ANFAVEA, 2014; FAO, 2014).

O crescente interesse na evolução da produtividade tem como fundamento o suprimento de alimentos no mundo, tendo em vista o aumento sucessivo na população (GASQUES et al., 2013). O crescimento da produtividade na agricultura reflete aumentos na eficiência dos processos de produção ao longo do tempo, sendo um fator determinante da rentabilidade agrícola e um mecanismo importante para a manutenção da competitividade internacional da agricultura. O crescimento da produtividade agrícola é impulsionado por melhorias de eficiência por conta de adoção de tecnologias e, também, dependente de um ambiente regulatório e institucional que expõe os agricultores a concorrência no mercado (GRAY; JACKSON; ZHAO, 2011). No Brasil, a agricultura, de um modo geral, tem produtividade elevada. De acordo com Gasques, Bastos e Bacchi (2009), o crescimento da produtividade tem sido o principal fator para o incremento da produção do agronegócio no Brasil.

Tomando por base o segmento da agricultura abordado no presente estudo, a fruticultura, o Brasil apresentou crescimento de 33\% na produtividade entre 1960 e o ano de 2012 (FAO, 2014). Segundo dados da FAO (2014), a produtividade de frutas, em geral, do Brasil é maior que a média mundial e que a da União Europeia, ficando atrás apenas dos Estados Unidos (Figura 8).

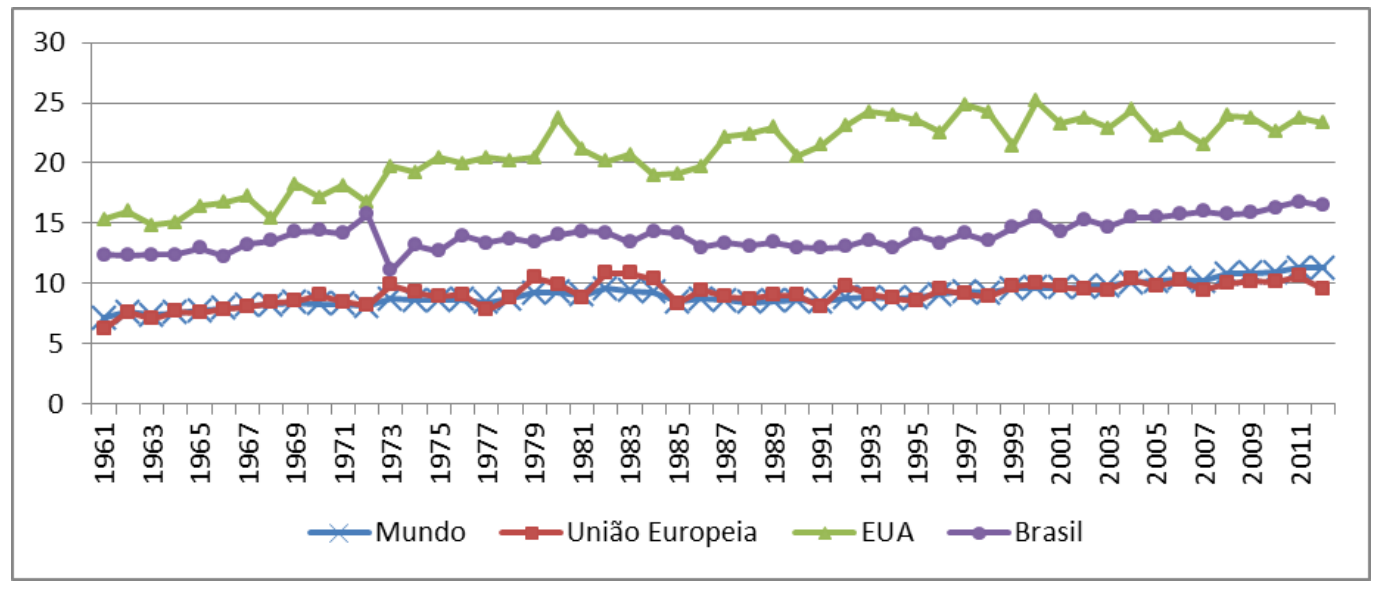

Figura 8. Evolução da produtividade total de frutas, em geral (em toneladas/hectare). 
Fonte: FAO (2014)

Porém, alguns autores compartilham de uma ideia: de que a produtividade real e total é difícil de ser medida. Para isso, muitos acadêmicos tem utilizado a Produtividade Total dos Fatores (PTF) para avaliar o rendimento médio da agricultura, a exemplo de Gasques e colaboradores (2004), Gray, Jackson e Zhao (2011), Gasques e colaboradores (2013) e Felema, Raiher e Ferreira (2013). A PTF é uma medida para aferição mais eficiente da produtividade que utiliza todos os insumos da produção agropecuária, como capital, terra, mão de obra e outros insumos intermediários (GASQUES et al., 2004; GRAY; JACKSON; ZHAO, 2011). O cálculo da PTF é realizado por uma função de produção tipo Cobb-Douglas (BARBOSA-FILHO, 2014). Ainda existe a Produtividade Parcial dos Fatores (PPF), que é amplamente usada na agricultura e é a medida de produção por área - por exemplo, toneladas/hectare (GRAY; JACKSON; ZHAO, 2011).

No Brasil, Gasques e colaboradores (2013), avaliaram a PTF no Brasil entre 1975 e 2011, que cresceu 3,56\% neste período - a maior taxa de crescimento, porém, foi no século XXI (entre 2000 e 2011), com média de 5,69\%. Esta taxa é elevada frente a outros países. Segundo os autores, o crescimento da produtividade, sobretudo da mão de obra e da terra, no período foi impulsionado, entre outros motivos, pelo uso mais intensivo de defensivos e fertilizantes químicos e maquinário mais eficiente.

\subsection{Hipóteses de pesquisa}

Com base nos objetivos do trabalho e no referencial teórico acima, formulou-se 4 (quatro) hipóteses de pesquisa:

1. A região produtora de uva de mesa do Vale do São Francisco (BA/PE) é a mais competitiva no Brasil, tendo em vista os melhores padrões tecnológicos.

2. A viticultura brasileira ganha/adapta tecnologia para substituir a falta de mão de obra. 
3. No Brasil, os recursos (mão de obra, tecnologias de produção/maquinário, etc.) são fatores mais positivos para a competitividade do mercado doméstico do que as instituições nacionais (regras, políticas, legislações, etc.).

4. O ambiente institucional é o fator que mais pesa na competitividade do mercado internacional de uva de mesa 


\section{Capítulo 3 - Metodologia}

\subsection{Metodologia}

Neste capítulo, será apresentada a metodologia de trabalho para se alcançar os objetivos da pesquisa.

A estrutura da metodologia deste trabalho será a triangulação (Figura 9). Segundo Neves (1996), “a triangulação pode estabelecer ligações entre descobertas obtidas por diferentes fontes, ilustrá-las e torna-las mais compreensíveis; pode também conduzir paradoxos, dando nova direção aos problemas a serem pesquisados". Triviños (1987) também cita a técnica de triangulação na coleta de dados. Esta técnica usa múltiplos dispositivos de coleta de dados, fontes, análises, etc., para estabelecer a validade dos resultados. A triangulação tem como objetivo obter a melhor e maior amplitude na descrição e compreensão do estudo.

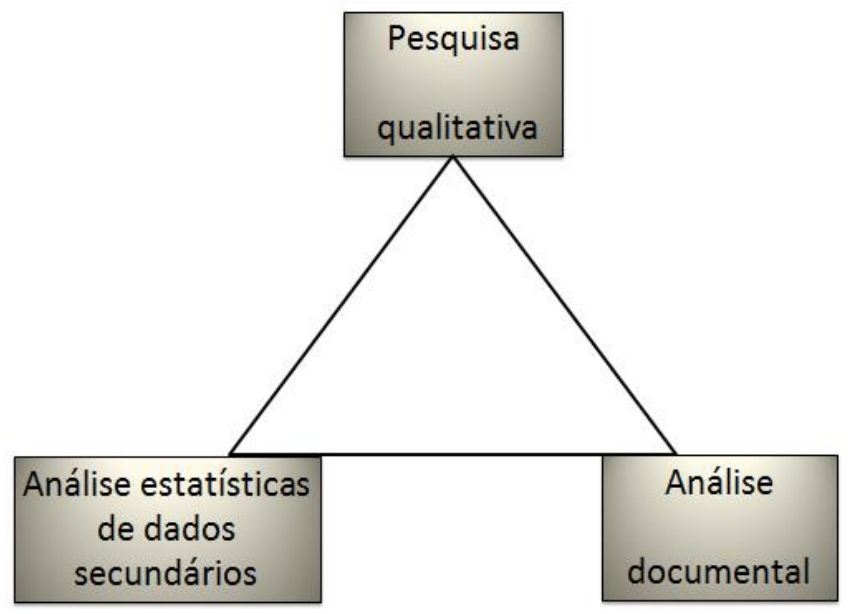

Figura 9. Técnica de levantamento de dados da pesquisa

A técnica de triangulação nesta pesquisa será constituída por:

- Pesquisa qualitativa: entrevista com produtores das principais regiões produtoras de uva de mesa do Brasil. A entrevista é baseada em um roteiro elaborado pela autora (disponível no Apêndice A). 
- Análise estatística de dados secundários: a avaliação da evolução dos preços das regiões produtoras de uva de mesa é baseada no banco de dados do Centro de Estudos Avançados em Economia Aplicada (Cepea) da Escola Superior de Agricultura Luiz de Queiroz da Universidade de São Paulo (Esalq/USP). Este tipo de análise também será usado para a comparação com outros países que produzem uva de mesa é realizada com base nos dados disponíveis da Organização das Nações Unidas para Agricultura e Alimentação (FAO), do Departamento Agrícola dos Estados Unidos (USDA) e da Comissão Europeia (banco de dados Eurostat).

- Análise documental: esta análise permite o levantamento das legislações, normas e outros documentos oficiais que influenciam o ambiente institucional da produção e comercialização de uva de mesa do Brasil.

Para concluir, deve ser realizada uma análise SWOT para identificar os pontos fortes e fracos de cada região produtora de uva de mesa e do Brasil, como um todo. A análise SWOT, do inglês, Strengths (forças), Weaknesses (fraquezas), Opportunities (oportunidades) e Threats (ameaças), é uma ferramenta simplista e prática da gestão estratégica e é usada para categorizar fatores internos e externos à organização ou a um setor. Os pontos fortes e fracos (ou forças e fraquezas) são relativos ao ambiente interno das organizações, setores e produção. Já as oportunidades e ameaças são inerentes ao ambiente externo (PICKTON; WRIGHT, 1998). Apesar de todas as críticas inerentes à análise SWOT, muitos autores ainda a utilizam como base para uma análise estratégica.

Os passos da metodologia serão detalhados nos tópicos a seguir.

\subsubsection{As regiões produtoras de uva selecionadas}

Para classificar as regiões, tomaremos por base a classificação obtida em Camargo, Tonietto e Hoffmann (2011).

Para esses autores, a viticultura pode ser dividida em três categorias: temperada, subtropical e tropical. No Brasil, todas podem ser encontradas. A primeira tem como 
característica principal a produção apenas uma vez ao ano, e seu período de dormência ${ }^{11}$ é induzido por baixas temperaturas durante o inverno. No Brasil, a viticultura temperada pode ser encontrada nos estados do Rio Grande do Sul, Santa Catarina, Paraná e em regiões serranas de São Paulo e Minas Gerais. A segunda, em condições naturais, também tem um ciclo anual e período de dormência nos meses de junho e julho. Porém, com manejo adequado, a videira consegue produzir duas vezes ao ano nas regiões norte do Paraná e leste de São Paulo. A última é típica de regiões onde o inverno não é rigoroso, que não induz naturalmente a dormência da videira. Está presente principalmente no Vale Submédio do São Francisco, noroeste paulista e norte de Minas Gerais, locais que adotam tecnologia que permite a colheita duas ou até três vezes ao ano na mesma planta (CAMARGO; TONIETTO; HOFFMANN, 2011).

A fim de selecionar as principais regiões produtoras do Brasil e caracterizá-las conforme a descrição acima foram tomados por base os dados do Instituto Brasileiro de Geografia e Estatística (IBGE).

Foram selecionados, primeiramente os quatro maiores estados produtores do Brasil conforme a Tabela 2, contida no item 1.2.1. deste trabalho, que são: Pernambuco, São Paulo, Paraná e Bahia. A partir disso, foram gerados cartogramas das áreas de uva (em hectares) das mesorregiões geográficas a partir do banco de dados agregados SIDRA do IBGE - os dados consolidados mais atuais são do ano de 2012.

Em Pernambuco, maior estado produtor, três das mesorregiões apresentam produção de uva (Figura 10), sendo que a mesorregião São Francisco Pernambucano detinha 6.211 hectares de uva, quase $92 \%$ da área do estado em 2012. Esta região, ainda, faz parte do Vale do São Francisco, principal polo produtor e exportador de uva do Brasil. Assim, esta é uma das regiões selecionadas para este trabalho. No São Francisco Pernambucano, a maior microrregião produtora é Petrolina, que fica às margens do Rio São Francisco e contava com 6.194 hectares em 2012 (IBGE, 2014). Esta região selecionada se enquadra na viticultura tropical, segundo as definições de Camargo, Tonietto e Hoffmann (2011).

\footnotetext{
${ }^{11}$ Período de dormência é um período vegetativo das árvores frutíferas, quando as plantas guardam energia para o próximo período produtivo. Durante esta fase, são necessárias horas com temperaturas iguais ou abaixo de $7,2^{\circ} \mathrm{C}$ - no caso da videira são necessárias de 90 a 400 horas de frio (Definição consultada em 24 de jun de 2014 e disponível em: <http://www.cpact.embrapa.br/publicacoes/livros/fundamentos-fruticultura/3.2.htm>)
} 


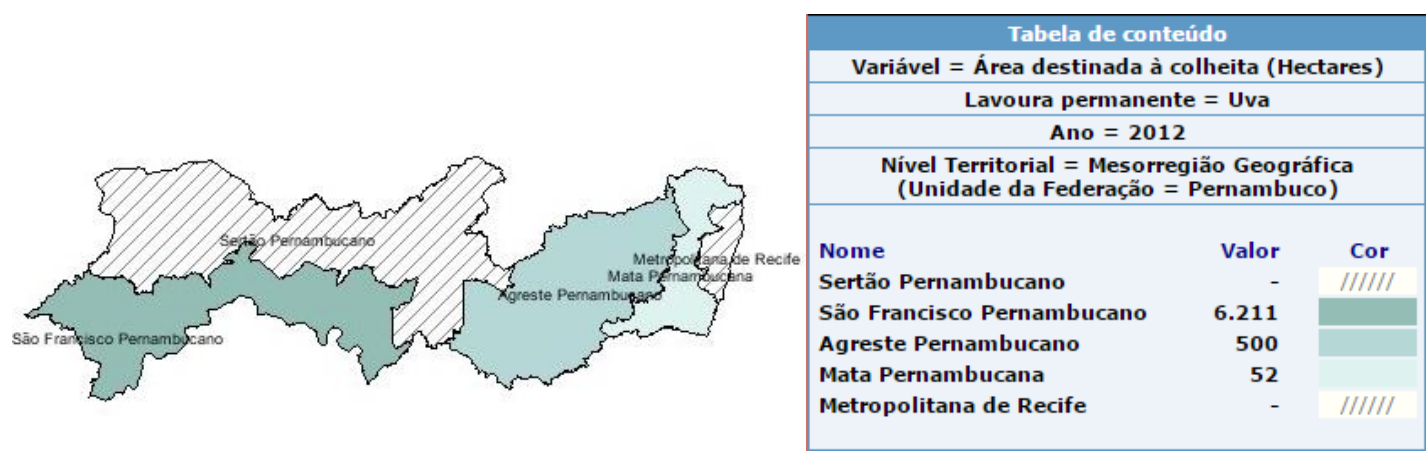

Figura 10: Mesorregiões produtoras de uva no estado de Pernambuco no ano de 2012

Fonte: IBGE (2014)

No estado de São Paulo, pioneiro na produção de uva de mesa no País, 12 mesorregiões registram produção de uva dentre as 15 existentes. Porém, a maior concentração das áreas de uva está em três regiões, que, por este motivo, foram selecionadas para este trabalho. São elas, em ordem de importância: Macro Metropolitana Paulista, Campinas e São José do Rio Preto (Figura 11).

A primeira tem 7.628 hectares, representando $69 \%$ do estado. Nesta mesorregião, as principais microrregiões produtoras são Piedade, Jundiaí e Sorocaba, em ordem de importância. A segunda mesorregião, Campinas, registrou, em 2012, 2.219 hectares, com $20 \%$ do estado. Nesta, a principal microrregião é a própria Campinas, com 2.196 hectares. Estas duas mesorregiões se enquadram na viticultura subtropical, segundo a classificação de Camargo, Tonietto e Hoffmann (2011).

A terceira tem 976 hectares, com $8 \%$ de representatividade do estado de São Paulo e tem como microrregião produtora Jales, que conta com 928 hectares (IBGE, 2014). Esta última mesorregião paulista pode ser classificada como viticultura tropical, segundo Camargo, Tonietto e Hoffmann (2011). 


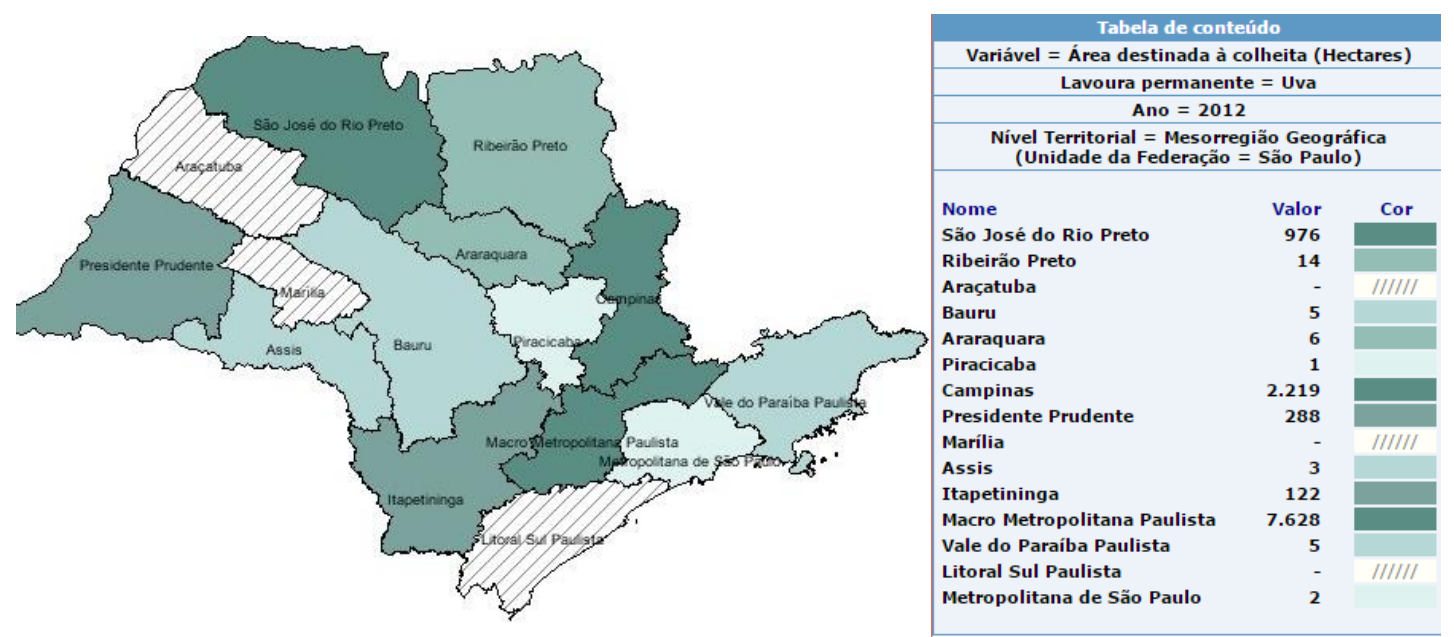

Figura 11: Mesorregiões produtoras de uva no estado de São Paulo no ano de 2012

Fonte: IBGE (2014)

No Paraná, todas as 10 mesorregiões geográficas tem alguma produção de uva (Figura 12). As duas mais importantes, em termos de área, são o Norte Central Paranaense e Norte Pioneiro Paranaense, com $42 \%$ e $22 \%$ de representatividade do estado em 2012, respectivamente. A primeira, que conta com 2.066 hectares, tem como principais microrregiões Maringá (1.650 hectares) e Ivaiporã (215 hectares). Na segunda mesorregião, que soma 1.054 hectares, as principais microrregiões são Assaí (528 hectares) e Cornélio Procópio (367 hectares) (IBGE, 2014). Essas mesorregiões situadas no Norte do Paraná são consideradas como viticultura de mesa subtropical, de acordo com as classificações de Camargo, Tonietto e Hoffmann (2011).Por estarem situadas na mesma região do estado, por conveniência, este trabalho considerará para as análises as duas regiões, juntas, como Norte do Paraná, somando 3.120 hectares.

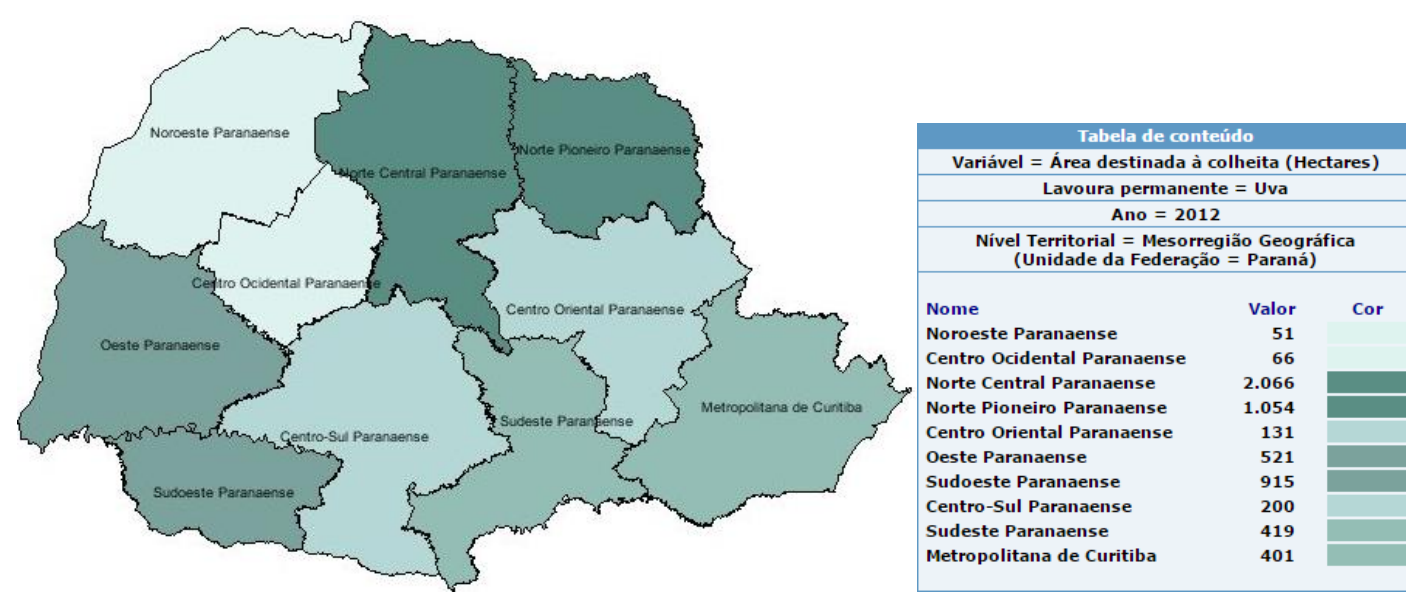

Figura 12: Mesorregiões produtoras de uva no estado do Paraná no ano de 2012

Fonte: IBGE (2014) 
$\mathrm{Na}$ Bahia, quatro das seis mesorregiões produzem uva. Destas quatro, o Vale SãoFranciscano da Bahia teve representatividade de $98 \%$ da produção de uva do estado da Bahia em 2012, sendo a região selecionada (Figura 13). Esta mesorregião contava com 2.452 hectares naquele ano e tem como principal microrregião Juazeiro (2.444 hectares) (IBGE, 2014). A região ainda faz parte do polo produtor de frutas do Vale do São Francisco, podendo ser considerada juntamente com a mesorregião de São Francisco Pernambucano para as análises. Juntas, as duas mesorregiões do Vale do São Francisco somam 8.655 hectares.

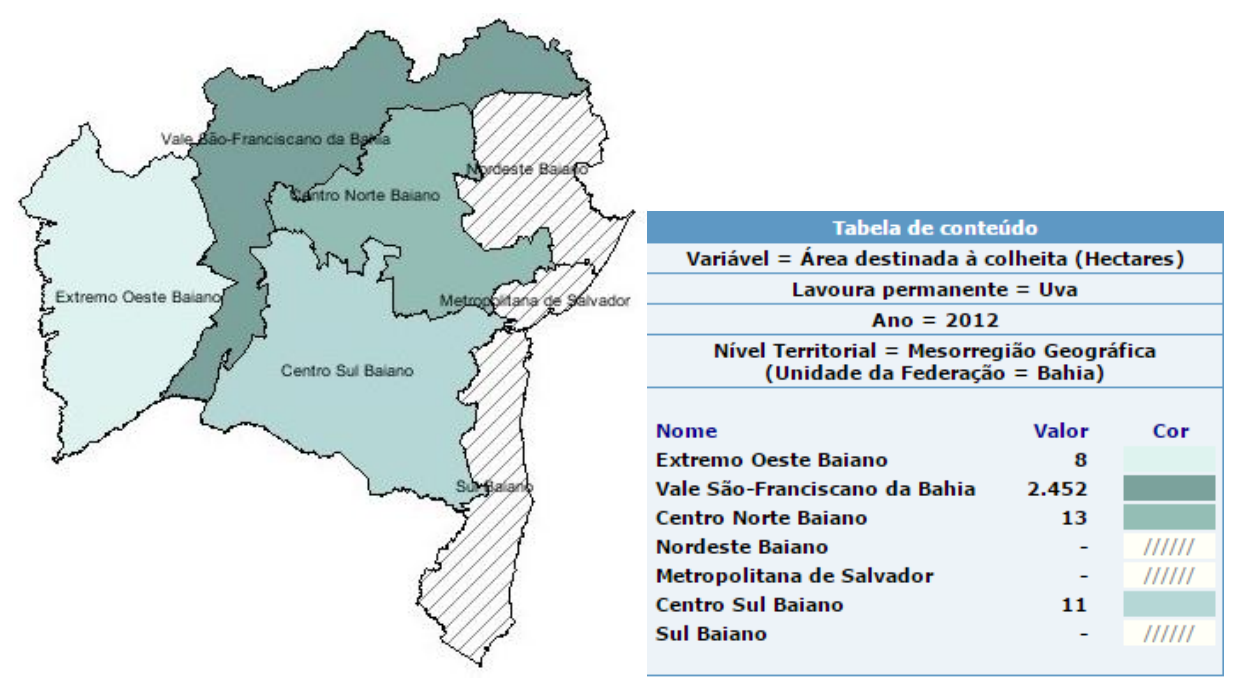

Figura 13: Mesorregiões produtoras de uva no estado da Bahia no ano de 2012 Fonte: IBGE (2014)

A partir dos dados e observações acima, as regiões a serem estudadas neste trabalho e sua classificação podem ser observadas na Tabela 5. Nesta tabela contam, ainda, os principais munícipios produtores de uva das microrregiões geográficas mais importantes conforme dados do IBGE.

Tabela 5. Regiões de uva de mesa selecionadas neste trabalho

\begin{tabular}{lccc}
\hline \multicolumn{4}{c}{ Regiões produtoras de uva selecionadas } \\
\hline $\begin{array}{c}\text { Mesorregião } \\
\text { Geográfica }\end{array}$ & Principais municípios & Classificação & $\begin{array}{c}\text { Área (em } \\
\text { hectares) }\end{array}$ \\
\hline $\begin{array}{l}\text { Vale do São Francisco } \\
\text { (BA/PE) }\end{array}$ & $\begin{array}{c}\text { Juazeiro (BA) e Petrolina } \\
\text { (PE) }\end{array}$ & $\begin{array}{c}\text { Viticultura } \\
\text { Tropical }\end{array}$ & 8.655
\end{tabular}




\begin{tabular}{lccc}
$\begin{array}{l}\text { Macro Metropolitana } \\
\text { Paulista (SP) }\end{array}$ & $\begin{array}{c}\text { Jundiaí, Pilar do Sul, São } \\
\text { Miguel Arcanjo e Porto } \\
\text { Feliz }\end{array}$ & $\begin{array}{c}\text { Viticultura } \\
\text { Subtropical }\end{array}$ & 7.628 \\
Campinas (SP) & $\begin{array}{c}\text { Campinas, Louveira e } \\
\text { Indaiatuba }\end{array}$ & $\begin{array}{c}\text { Viticultura } \\
\text { Subtropical }\end{array}$ & 2.219 \\
$\begin{array}{l}\text { São José do Rio Preto } \\
\text { (SP) }\end{array}$ & $\begin{array}{c}\text { Jales, Palmeira D'Oeste e } \\
\text { Urânia }\end{array}$ & $\begin{array}{c}\text { Viticultura } \\
\text { Tropical }\end{array}$ & 976 \\
Norte do Paraná & $\begin{array}{c}\text { Marialva, Assaí, Uraí, } \\
\text { Bandeirantes e Rosário do } \\
\text { Ivaí }\end{array}$ & $\begin{array}{c}\text { Viticultura } \\
\text { Subtropical }\end{array}$ & 3.120 \\
\hline Fonte: Elaborado pela autora com base em IBGE (2014) e Camargo, Tonietto e Hoffmann (2011).
\end{tabular}

\subsubsection{Amostragem da pesquisa qualitativa}

Em uma pesquisa, a utilização da amostra é quase sempre necessária. Quase sempre, porque, segundo Sampieri, Collado e Lucio (2006), em estudos que usam o censo, toda a população é estudada, ou seja, não há amostra. Amostra é uma parte selecionada da população, de acordo com Marconi e Lakatos (2003). No geral, amostras adequadamente selecionadas fornecem dados importantes e oferecem resultados satisfatórios para a pesquisa. No enfoque qualitativo, a amostra não precisa, necessariamente, representar o todo, e dela deve-se extrair dados passíveis de pesquisa científica (SAMPIERI; COLLADO; LUCIO, 2006).

Neste estudo, a população são todos os produtores de uva de mesa do Brasil, e a amostra é constituída por indivíduos selecionados convenientemente de cada região produtora em estudo. Amostras por conveniência, como a desta pesquisa, fazem parte de um grupo chamado de amostras não-probabilísticas.

Amostragem não-probabilística, segundo Malhotra (2012), é uma técnica "que não utiliza seleção aleatória. Ao contrário, confia no julgamento pessoal do pesquisador" (MALHOTRA, 2012, p. 274). Um porém quanto a este tipo de amostragem é que os resultados não podem ser extrapolados para a população, sendo características somente da amostra pesquisada. Na amostragem não-probabilística, ainda, está incluída a amostragem por conveniência. Este tipo de amostragem é uma técnica em que a seleção dos indivíduos é feita 
pelo pesquisador. Segundo Malhotra (2012), neste tipo de análise, as pessoas geralmente são acessíveis e cooperadoras.

Assim, a amostra não-probabilística de conveniência deste estudo são os produtores de uva de mesa cadastrados na comunidade do Projeto Hortifruti do Cepea (Centro de Estudos Avançados em Economia Aplicada), da Escola Superior de Agricultura Luiz de Queiroz (Esalq)/Universidade de São Paulo (USP). Neste banco de dados, há 142 produtores de uva de mesa cadastrados, nas regiões selecionadas para esta pesquisa - número que reflete a amostra em potencial deste estudo. Neste banco de dados, ainda, estão aqueles produtores que determinam a oferta da fruta no mercado interno. Além disso, há contatos também de formadores de opinião deste setor, que serão consultados.

Dentro da amostra, estão contidos todos os tipos de organizações da viticultura de mesa: produtores familiares, produtos de menor porte que não se enquadram em agricultura familiar, cooperativas e grandes empresas.

Anteriormente às entrevistas base deste trabalho, foi realizado um pré-teste entre $02 \mathrm{e}$ 10/fevereiro de 2015 com três (03) produtores de uva de mesa da região de Pirapora, Minas Gerais. O pré-teste é importante para a validação do formulário de perguntas, buscando identificar a clareza e precisão dos termos utilizados, a quantidade de perguntas, a forma que as perguntas foram elaboradas, a ordem das perguntas e a forma de introdução da pesquisa (GIL, 2010). Após os testes, o formulário teve alguns ajustes.

As entrevistas, propriamente ditas, foram realizadas entre os dias 19/março e 30/abril de 2015, e duraram entre 15 e 40 minutos cada, dependendo da disposição e tempo do entrevistado. Foram entrevistados 40 produtores de uva de mesa, sendo oito (08) em cada região-alvo deste estudo - Norte do Paraná, Vale do São Francisco (BA/PE), região de Campinas (SP), região de São José do Rio Preto (SP) e região Macro Metropolitana Paulista.

\subsubsection{Pesquisa Qualitativa}

A pesquisa qualitativa é uma das possibilidades de realizar um estudo no qual esteja intrínseco as relações entre as pessoas, as empresas, entre outras maneiras de relação existentes no ambiente (GODOY, 1995). Dessa maneira, a pesquisa qualitativa pode ser 
conduzida de diferentes maneiras, partindo de questões amplas que devem ir se esclarecendo com o decorrer do estudo.

Os mesmos instrumentos usados na pesquisa qualitativa são aqueles das quantitativas, segundo Triviños (1987). O autor relata que as entrevistas e questionários, por exemplo, são meios neutros para a coleta e dados, até mesmo as questões fechadas são passíveis de análise qualitativa. Além disso, Godoy (1995) relata que a pesquisa qualitativa, enquanto método, "não apresenta uma proposta rigidamente estruturada, ela permite que a imaginação e a criatividade levem os investigadores a propor trabalhos que explorem novos enfoques". Diante da perspectiva desses dois autores, podemos ressaltar que a pesquisa qualitativa pode ser "muito rica" em termos de conhecimento e resultado, mas isso depende também do pesquisador saber conduzir seu estudo criativa e corretamente.

De modo geral, a pesquisa qualitativa compreende um conjunto de técnicas que visam analisar o ambiente e campos de estudo mais específicos sem o uso das complexas metodologias matemática e estatística. De certa forma, esse estudo empírico facilita a compreensão da realidade através de dados simbólicos (NEVES, 1996).

Para a realização de uma boa pesquisa qualitativa, deve ser escolhida a melhor técnica de coleta de dados para cada estudo. Dentre as técnicas que podem ser usadas estão as entrevistas semi-estrurada (aberta ou livre) e estruturada, questionário aberto, observação livre, método de análise de conteúdo, entre outros (TRIVIÑOS, 1987). Todas estas técnicas citadas devem ter atenção especial do observador/pesquisador em relação aos informantes e às “anotações de campo".

Neste trabalho, foi utilizada a técnica qualitativa de entrevistas semi-estruturadas e abertas. As entrevistas, semi-estruturadas são uma série de perguntas feitas ao entrevistado verbalmente e com uma sequência prevista, mas que pode ser acrescentadas perguntas de esclarecimento ao longo da entrevista (LAVILLE; DIONNE, 1999). Entrevistas, segundo Duarte (2004, p. 215) são

"fundamentais quando se precisa/deseja mapear práticas, crenças, valores e sistemas classificatórios de universos sociais específicos, mais ou menos bem delimitados, em que os conflitos e contradições não estejam claramente explicitados. Nesse caso, se forem bem realizadas, elas permitirão ao pesquisador fazer uma espécie de mergulho em profundidade, coletando indícios dos modos como cada um daqueles sujeitos percebe e significa sua realidade e levantando informações consistentes que lhe permitam descrever e 
compreender a lógica que preside as relações que se estabelecem no interior daquele grupo, o que, em geral, é mais difícil obter com outros instrumentos de coleta de dados".

O método de levantamento dos dados é classificado pela forma de aplicação das entrevistas (MALHOTRA, 2012). Neste estudo, as entrevistas foram conduzidas por telefone. Esse tipo de entrevista apresenta a vantagem de que o entrevistador pode esclarecer dúvidas, explorar respostas ambíguas, além de o próprio formular e anotar as respostas. Muitas vezes, em questionários auto preenchidos - que os entrevistados preenchem - podem gerar dúvidas na fase de análise das respostas (ALMEIDA, 2011; MALHOTRA, 2012).

O pesquisador deve ter consigo uma série de questões, chamadas de roteiro da entrevista ou formulário (SILVA; MENEZES, 2005). O roteiro tem como finalidade deixar o entrevistado falar mais livremente sobre o assunto abordado. Embora o planejamento de um roteiro seja de extrema importância, é importante que a entrevista não seja engessada. Assim, as perguntas podem não seguir a ordem do roteiro, pois o entrevistador deve deixar fluir a sequência lógica de informações que estão sendo faladas (TEIZEN, 2011).

A pesquisa qualitativa deste estudo tem como objetivo detalhar o perfil dos produtores de uva de mesa por região, caracterizando-os em relação a tamanho de propriedades (moda da amostra do estudo), variedades produzidas e se há predominância de produtores familiares ou não. Além disso, as entrevistas são a base para a avaliação do nível tecnológico de cada região produtora de uva de mesa e identificação dos fatores que levam às diferenças regionais, principalmente no que diz respeito à produtividade e competitividade. Foi investigado, também a partir da pesquisa qualitativa, como o ambiente institucional tem afetado a competitividade dos produtores de cada região. Por fim, a análise auxilia na identificação dos pontos fortes e fracos das principais regiões produtoras no Brasil. O roteiro de entrevista pode ser visualizado no Apêndice A deste trabalho.

Durante as entrevistas, ainda, foi utilizado o princípio da saturação. Esse princípio preconiza a cessação de acréscimo de novas observações no trabalho, tendo em vista que mais informações não alterariam a compreensão dos resultados. A aplicação de entrevistas semiestruturadas e de respostas abertas é a forma mais comum da utilização deste princípio, pelo qual a saturação é atingida quando não há mais novos temas e informações registradas (THIRY-CHERQHES, 2009). Thiry-Cherques (2009) recomenda no mínimo 6 (seis) entrevistas para ter a saturação, e pelo menos mais duas observações para garantir o princípio. 
Após as entrevistas, foi utilizado o software de origem alemã Atlas.ti (em inglês, (Archive for Technology, the Lifeworld, and Everyday Language) versão 7.0 para análise. Este software auxilia em análise de dados qualitativos, principalmente interpretação de texto, tendo em vista que melhora a capacidade de lidar com grandes quantidades de texto, incluindo as relações conceituais que surgem durante o processo de interpretação. Vale ressaltar, porém, que a interpretação é totalmente humana, ou seja, é o pesquisador que faz a interpretação e relação - o software auxilia nesse processo (MUHR, 1991).

\subsubsection{Obtenção dos dados secundários}

Dados secundários são aqueles disponíveis publicamente ou para pessoas cadastradas no fornecedor da informação - não são dados coletados pelo pesquisador do trabalho. Os dados secundários podem ser classificados de diferentes formas, sendo que a mais usual é de dados externos que se referem a situações econômicas e sociais de um país, região e de um mercado em específico. No caso da agricultura, são feitos vários levantamentos por diversas instituições com a finalidade de avaliar a agricultura (ARATANGY, 2011).

No presente trabalho, depois de identificadas as principais regiões produtoras de uva de mesa, foi utilizado o banco de dados do Cepea (Centro de Estudos Avançados em Economia Aplicada), da Escola Superior de Agricultura Luiz de Queiroz (Esalq)/Universidade de São Paulo (USP), para auxiliar na identificação da região mais competitiva. O banco de dados dispõe de série de preços desde 2001. Foram, ainda, escolhidas as duas variedades de uva mais representativas em termos de produção nacional: itália (representando as uvas finas) e niagara (representando a uva rústica). Essa escolha foi feita com base nas conversas e explicações de pesquisadores do Cepea. 


\subsubsection{Análise documental: $o$ ambiente institucional da viticultura}

A análise documental é um procedimento metodológico que tem o documento como objeto de investigação - documentos ainda passíveis de análises, fontes primárias. Essa análise possibilita a compreensão de assuntos relevantes para a pesquisa, mas que datam do passado, e de informações que podem ser resgatadas em documentos. A análise documental incrementa a pesquisa qualitativa com informações importantes que possam complementar e auxiliar nas conclusões do trabalho (SÁ-SILVA; ALMEIDA; GUINDANI, 2009).

Os documentos trazem as informações diretamente. Segundo Laville e Dionne (1999), “os dados estão lá, resta fazer sua triagem, criticá-los, isto é, julgar sua qualidade em função das necessidades da pesquisa" (LAVILLE; DIONNE, 1999, p. 167).

No presente trabalho, a análise documental foi concentrada em legislações, políticas governamentais (tributárias, de financiamento, de fiscalização), políticas de comércio exterior, regulamentações e outros materiais relevantes para o ambiente institucional da viticultura brasileira.

O agronegócio é um dos setores de mais intensa regulamentação - um grande número de agências e órgãos governamentais supervisiona a produção de alimentos no mundo (DICKEN, 2010). Assim, assume-se a importância desta análise para os resultados e conclusões do presente trabalho. A análise documental deve ser realizada antes das entrevistas com os produtores de uva da amostra desta pesquisa.

Para isso, os documentos foram levantados e arquivados para, posteriormente, serem realizados os fichamentos. A partir disso, devem ser feitos quadros para facilitar a análise, como proposto por Pimentel (2001).

\subsubsection{Análise da competitividade regional}

Com toda a documentação levantada, entrevistas realizadas, e os dados secundários obtidos, foi realizada a análise da competitividade regional brasileira. Analisar, segundo Tognolli (2011), é o pesquisador dar sentido a qualquer fenômeno estudado. 
Em relação à análise documental e às entrevistas, Aratangy (2011) e Moraes (1999) sugerem a análise de conteúdo para produzir as inferências de maneira objetiva sobre os assuntos levantados. A análise das entrevistas proporciona o entendimento de cada região junto aos diversos produtores.

A categorização da análise de conteúdo agrupa as informações conforme exista uma parte comum entre elas, tanto dos documentos quanto das entrevistas. Nesta fase, é importante que se estabeleçam cinco critérios. O primeiro é a validade, que consiste em se adequar aos objetivos da análise e às questões que se pretende responder para auxiliar na pesquisa - a validade deve, ainda, se fundamentar na teoria proposta. O segundo critério é a exaustividade. Neste, deve haver a inclusão de todas as unidades passíveis de análises, ou seja, enquadrar todo o conteúdo de forma abrangente. O terceiro critério é a homogeneidade, ou seja, todo o conteúdo, quer seja da entrevista ou do documento, deve ser estruturado em uma única dimensão de análise. A exclusividade é o quarto critério. Neste, cada elemento deve pertencer a apenas uma categoria. O último critério é o da objetividade, consistência ou fidedignidade. Se o pesquisador atender a este critério, deverá chegar a resultados semelhantes a de outros pesquisadores que fizerem a mesma análise, com o mesmo conteúdo (MORAES, 1999).

Quanto à descrição, faz parte da comunicação dos resultados da análise. Para isso, deve ser escrito uma texto síntese para cada categoria proposta, onde deve ser expressado o significado das unidades de análise. Pode-se, ainda, fazer o uso de citações diretas durante a descrição (MORAES, 1999).

Uma boa análise de conteúdo, porém, não deve se limitar à descrição. Para isso, deve ser realizada a interpretação para uma compreensão mais aprofundada sobre o conteúdo. A interpretação é imprescindível em análises qualitativas (MORAES, 1999).

Para os dados secundários, foi realizada, primeiramente, uma estatística descritiva dos dados, ou seja, descrição das características dos dados obtidos (DOMINGUES; DOMINGUES, 2010). Aratangy (2011) sugere algumas interpretações qualitativas dos dados antes da análise estatística propriamente dita, tendo em vista que é necessário entender o significado dos dados numéricos para conseguir resolver a questão do problema. Os dados secundários analisados foram as série de preços de uva obtidas pelos produtores das regiões selecionadas. Os dados foram obtidos no banco de dados do Cepea.

Quanto aos dados, a princípio, seriam estudados no contexto de dados longitudinais, quando várias observações são feitas em um mesmo indivíduo ao longo do tempo (nesse caso, o produtor de uva de mesa). Quando isso acontece, tende a surgir uma correlação entre as medidas observadas em cada indivíduo. Entretanto, notou-se que a estrutura dos dados é 
bastante irregular, tendo em vista que parte dos produtores foi observada em poucos anos. Assim, as técnicas testadas que levassem em consideração essa dependência citada não surtiram efeito e modelos que consideram as observações independentes (MLG) entre si tiveram um bom ajuste.

$\mathrm{Na}$ análise estatística dos dados, assim, foi utilizada a teoria dos Modelos Lineares Generalizados (MLG). Apesar das restrições, a utilização de MLG tem sido cada vez mais comum em análises estatísticas, tendo em vista o avanço dos recursos computacionais. Os Modelos Lineares Generalizados foram introduzidos por Nelder e Wedderburn (1972) para se unificar as várias abordagens existentes no campo da estatística, tanto do ponto de vista teórico quanto do conceitual. São casos de MLG os modelos de regressão linear clássico, de análise de variância e covariância, de regressão logística, de regressão de Poisson, modelos log-lineares para tabelas de contingência multidimensionais, modelo probit para estudos de proporções, entre outros. O MLG, ainda, consiste de três componentes:

(i) uma resposta univariada com distribuição associada pertencente à família exponencial (componente aleatório), com função densidade de probabilidade (fdp)

$$
f\left(y_{i} ; \Theta_{i}, \phi\right)=\exp \left\{\phi^{-1}\left[y_{i} \Theta_{i}-b\left(\Theta_{i}\right)\right]+c\left(y_{i}, \phi\right)\right\} \quad i=1, \ldots, \mathrm{n} ;
$$

(ii) um preditor linear relacionado às variáveis explicativas

$$
\eta=X \beta
$$

Em que $\beta$ é um vetor de $p$ parâmetros desconhecidos e $\mathrm{X}=[\mathrm{x} 1, \ldots, \mathrm{xn}]$, é a matriz de delineamento $\mathrm{n} x \mathrm{p}$, e

(iii) uma função de ligação $\eta_{i}=g\left(\mu_{i}\right)$, relacionando os componentes sistemático e aleatório. Tem-se $\mu_{i}=E\left[Y_{i}\right]=b^{\prime}\left(\Theta_{i}\right)$ e $\operatorname{Var}\left[Y_{i}\right]=\phi b^{\prime \prime}\left(\Theta_{i}\right)=\phi V\left(\mu_{i}\right)$, onde $V\left(\mu_{i}\right)$ é chamada de função de variância (Demétrio et al., 2014).

Entre as distribuições de probabilidade pertencentes à família exponencial (Equação 1) estão a distribuição normal e gama, utilizadas para dados de natureza contínua (como é o caso deste trabalho). A distribuição gama foi utilizada na modelagem do preço, pois os valores assumidos por estas variáveis são sempre positivos. A fdp da distribuição normal é mostrada a seguir: 


$$
f\left(y ; \mu, \sigma^{2}\right)=\frac{1}{2 \pi \sigma^{2}} \exp \left[-\frac{1}{2 \sigma^{2}}\left(y-\mu^{2}\right)\right]
$$

A estimação dos parâmetros em MLG é feita pelo método da máxima verossimilhança. A seleção dos modelos finais foi feita analisando-se os seguintes critérios:

- análise de deviance de modelos propostos (Demétrio et al., 2014);

- critério de informação de Akaike (1974);

- comparação dos valores observados e preditos, por meio de gráficos e coeficientes de correlação linear de Pearson;

- análise de resíduos dos modelos, por meio de half-normal plots (Demétrio et al., 2014; Moral et al., 2014). Considerou-se um ajuste satisfatório quando menos de $5 \%$ dos pontos ficaram fora do envelope de simulação.

Mais detalhes podem ser encontrados em Magalhães e de Lima (2010); Ferreira (2009); Gibbons e Chakraborti (2003).

Nos resultados, a variável em estudo será representada sempre por $y$, os anos por $t$. Todas as análises, desde a análise exploratória ao ajuste dos modelos, foram feitas no software R (R Core Team, 2014).

\subsubsection{Identificação dos países e comparação da competitividade internacional}

Em relação ao mercado internacional, os dois principais concorrentes do Brasil na viticultura foram identificados a partir de dados da Secretaria de Comércio Exterior (Secex), dados da FAO, do Departamento Agrícola dos Estados Unidos (USDA) e da Comissão Europeia (banco de dados Eurostat). Os principais concorrentes são aqueles que afetam, de alguma maneira, o mercado de uva de mesa do Brasil. Assim, foi identificado um país que afeta o mercado doméstico, ou seja, país que exporta uva para o Brasil, e um país que afeta os negócios internacionais, ou seja, que afeta o mercado internacional da uva brasileira de alguma forma. 
O Brasil importa uva de mesa geralmente no primeiro semestre de cada ano, conforme já explicitado no item 1.2. deste trabalho. De acordo com os dados do MDIC/SECEX (2014), os países que mais exportam uva para o Brasil são Chile e Argentina (Figura 14), que corresponderam em 2013 por $75 \%$ e 18\%, respectivamente, das compras totais de uva em 2013. Essa distribuição, porém, já foi de $48 \%$ e $47 \%$, respectivamente, no ano de 2010 e $28 \%$ para o Chile e $71 \%$ para a Argentina em 2008. Apenas a partir desses dados, o Chile tem ganhado competitividade em detrimento da Argentina, pelo menos no mercado brasileiro.

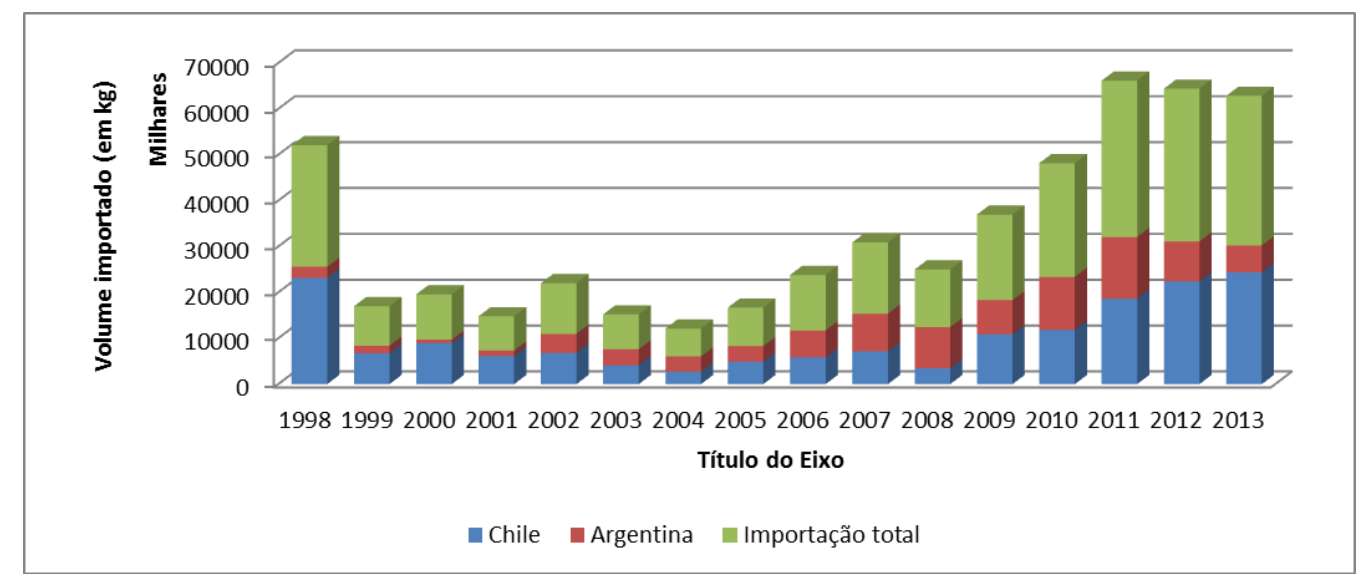

Figura 14. Evolução das importações brasileiras entre 1998 e 2013

Fonte: Elaborado pela autora com base nos dados do MDIC/SECEX (2014)

Nesse contexto, o Chile foi o país escolhido por afetar mais as negociações de uva brasileira no primeiro semestre de cada ano. No cenário internacional, vale procurar, também, aqueles que afetam as negociações brasileiras no segundo semestre - período no qual ocorrem as exportações brasileiras. O Brasil exporta uva principalmente para a Europa, sendo que o bloco econômico da União Europeia foi responsável por $88 \%$ das exportações brasileiras em 2013 e 92\% em 2014, em volume, de acordo com dados do MDIC/SECEX (2014). Assim, buscou-se o principal concorrente em cada mercado comprador para a análise de competitividade internacional.

Em relação à Europa, existem grandes e importantes produtores da fruta que exportam entre os países do continente, afetando, de certa forma, a comercialização da fruta brasileira. Segundo dados da Comissão Europeia (2014), a Turquia tem a maior produção de uva de mesa na Europa, com 54\% de representatividade, seguida pela Itália (28\%), Espanha $(6,5 \%)$ e Grécia (6\%) no ano de 2013. Esses quatro países, juntos, representam 95\% da produção total do continente. 
Já com relação às transações comerciais, a União Europeia (bloco econômico) é o maior comprador da uva brasileira. Assim, verificou-se qual é a posição no que diz respeito às vendas de uva para o bloco europeu desses países. A Itália é a principal fornecedora de uvas de mesa para a UE, sendo responsável por $27 \%$ de toda a compra de uva pelo bloco em 2013. A Espanha ficou em segundo lugar naquele ano, com $8 \%$ de representatividade, seguida pela Grécia com 5\% e pela Turquia, com 1\%, apenas, segundo dados da Comissão Europeia (Tabela 6). Esses dados não consideram o consumo dentro do país, ou seja, a Itália consome muita uva do próprio país, assim como consumidores espanhóis preferem a uva do seu país. Já o Brasil, é responsável por apenas $2 \%$ do volume de uvas que entra na UE.

Tabela 6. Evolução da importação de uva de mesa pela União Europeia

\begin{tabular}{lrrrr}
\hline País Fornecedor & $\mathbf{2 0 1 0}$ & $\mathbf{2 0 1 1}$ & $\mathbf{2 0 1 2}$ & $\mathbf{2 0 1 3}$ \\
\hline Itália & 369.623 & 388.152 & 397.722 & 417.526 \\
Espanha & 134.309 & 146.016 & 131.091 & 118.268 \\
Grécia & 90.638 & 74.203 & 62.866 & 83.405 \\
Brasil & 41.748 & 38.959 & 38.328 & 36.776 \\
Turquia & 24.157 & 29.827 & 23.139 & 18.953 \\
\hline Total & 1.507 .017 & 1.482 .070 & 1.501 .820 & 1.554 .575 \\
\hline Elaborado pela autora com base nos dados da Comissão Europeia (2014)
\end{tabular}

Analisando todos os países da Europa abordados, fica evidente que a Itália tem maior mercado para a uva de mesa, sendo o país escolhido naquele continente para a análise da competitividade frente ao Brasil.

A pergunta que fica é: como está a competitividade do Brasil frente a esses países? Identificados os dois países [Chile e Itália], foram realizadas análises de dados secundários (dados oficiais de cada país) e análise documental sobre os países selecionados. Com relação aos documentos, foi realizada a análise de conteúdo. O objetivo foi verificar o que os países concorrentes têm no seu ambiente que explicam porque são mais ou menos competitivos frente ao Brasil. Para as análises dos dados numéricos, foram feitas estatísticas descritivas e análises qualitativas dos dados. Para isso, foram levantados os dados de produção, produtividade, exportação, importação (de 2000 a 2013) e preços da uva de mesa comercializada no mercado internacional, de 2005 a 2014. Os dados do Brasil foram extraídos do Instituto Brasileiro de Geografia e Estatística (IBGE, 2014) e do Ministério da Indústria e Comércio Exterior por meio do sistema Aliceweb da Secretaria de Comércio Exterior (MDIC, 2014). Os dados do Chile foram retirados do Gabinete de Estudos e Políticas Agrárias 
(Odepa, 2015) e os da Itália, do banco de dados Eurostat, da Comissão Europeia (2014). Os preços no mercado internacional da uva para os três países foram extraídos do banco de dados do Departamento Agrícola dos Estados Unidos (USDA, 2014b). 


\section{Capítulo 4 - Análise dos resultados e discussão}

\subsection{Competitividade da viticultura brasileira}

\subsubsection{O Crédito e o Seguro Rural para o produtor de uva no Brasil}

Os documentos utilizados para a elaboração deste trabalho foram buscados a partir das bases do Ministério da Agricultura, Pecuária e Abastecimento (Mapa), do Ministério do Desenvolvimento Agrário (MDA), do Banco Nacional de Desenvolvimento Econômico e Social (BNDES) e do Ministério do Desenvolvimento, Indústria e Comércio Exterior (MDIC).

Vale destacar que neste item do trabalho foi proposta a análise do crédito agrícola e do seguro rural, que podem impactar na produção de uva de mesa do Brasil. Para esta pesquisa, esses dois são os itens principais do ambiente institucional para o produtor brasileiro quando se fala em apoio governamental. É claro que o ambiente institucional é bastante amplo e não se resume apenas a esses dois aspectos - a avaliação de associações e cooperativas regionais pode ser visualizada no item 4.1.3. deste trabalho.

Porém, no Brasil, ainda inexiste uma legislação que consolide todas as políticas públicas do setor agropecuário, como as existentes Farm Bill dos Estados Unidos e a Política Agrícola Comum (PAC) da União Europeia, com previsibilidade para os produtores em relação ao orçamento. Com o Plano Safra, anualmente o produtor tem que esperar o anúncio do orçamento que será destinado à agricultura, o qual é imprevisível. A questão da nova lei está sendo estudada pelo Ministério da Agricultura do Brasil e é meta entrar em vigor até 2020, sendo que o seguro deve ser o pilar desta nova lei (MAPA, 2015). 
Segundo Chaddad, Jank e Nakahodo (2006), o "Brasil é o único país do mundo com dois ministérios da agricultura: o ministério dos produtores patronais e agronegócio (MAPA) e o ministério dos agricultores familiares e da reforma agrária (MDA). Tais ministérios competem por recursos cada vez mais escassos e, frequentemente, expressam posições antagônicas sobre temas relevantes para o setor" (CHADDAD; JANK; NAKAHODO, 2006, p. 2). O produtor rural (e cooperativas destes), porém, se beneficia principalmente de dois recursos, os de auxílio de crédito rural e de seguro agrícola.

O crédito rural abrange recursos, sobretudo, para custeio e investimento na

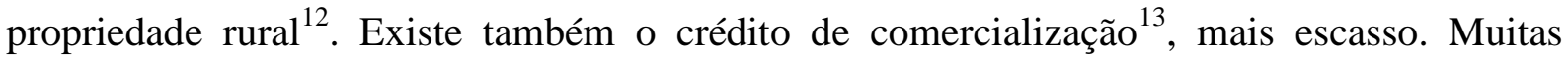
vezes, o produtor nem sabe da existência deste último tipo de crédito, como verificado nas entrevistas realizadas pela autora deste trabalho. Anualmente, o Governo Federal destina uma verba para os financiamentos de crédito e seguro rural - na safra 2014/15, o valor programado é de $\mathrm{R} \$ 156,1$ bilhões para a agricultura em geral, $767 \%$ a mais que o aplicado no ano safra 2001/02, e 137\% mais que no ano safra 2007/08, em valores nominais. A maior parte geralmente é destinada para crédito de custeio (Tabela 7). Além disso, o orçamento para Pesquisa e Tecnologia e Extensão Rural também provem do valor direcionado para a Agricultura (do Orçamento da União) (MAPA, 2015). Vale destacar que este valor é ainda subdividido e cada programa governamental tem um limite de crédito - por exemplo, na safra 2014/15, o valor destinado ao médio produtor rural (Pronamp) é de R \$10,55 bilhões total ou de R 355 mil por produtor; já o Inovagro tem valor programado de $\mathrm{R} \$ 1,7$ bilhão, sendo que cada produtor tem limite de, no máximo, R \$ 1 milhão (MAPA, 2015).

Tabela 7: Recursos destinados à agricultura por ano safra (em R \$ bilhões)

\begin{tabular}{ccc}
\hline Finalidade & Safra 2013/14 & Safra 2014/15 \\
\hline Custeio & 97,6 & 112 \\
Investimento & 38,4 & 44,1 \\
\hline Total & $\mathbf{1 3 6}$ & $\mathbf{1 5 6 , 1}$ \\
\hline
\end{tabular}

Fonte: MAPA, 2015

\footnotetext{
12 Créditos de custeio são referentes a despesas de ciclo produtivo, como compra de insumos. Já os de investimento são para bens e serviços que podem durar por muitos anos na propriedade rural, como construção de armazéns.

${ }^{13}$ Os créditos de comercialização podem assegurar ao produtor os recursos necessários à adoção de mecanismos que garantam o abastecimento e levem o armazenamento da colheita nos períodos de queda de preços.
} 
Neste cenário, foram levantados os principais Programas de Crédito Agrícola junto ao Mapa, MDA e BNDES (Apêndice B), que estão disponíveis para o produtor rural brasileiro. Foram extraídos apenas aqueles que podem ser adquiridos pelo viticultor de mesa.

De modo geral, o viticultor brasileiro pode ter acesso ao auxílio de muitos programas de crédito para investir e custear atividades do seu parreiral. O objetivo geral dos programas é garantir a atividade agrícola estimulando a tecnologia e produtividade no campo.

Porém, o produtor deve sempre estar atento ao seu enquadramento para pleitear os recursos, como, por exemplo, estar em área de zoneamento agrícola ${ }^{14}$ para o Proagro e Proagro Mais. No caso das regiões de uva pesquisadas neste trabalho, todas se beneficiam estados de São Paulo, Paraná, Bahia e Pernambuco - para as variedades de mesa americanas e europeias.

No estado de São Paulo, tanto uvas de cultivo irrigado quanto de sequeiro (sem irrigação) foram incluídas no zoneamento em 2010. O zoneamento indica o calendário de julho a dezembro para se conseguir recursos dos programas governamentais, ou seja, o produtor conseguirá pleitear a verba apenas para a uva que tiver em atividades de poda, colheita, entre outras atividades nesse período. Se houver danos nos parreirais fora do período indicado, pode não haver cobertura. No estado de SP, apenas a região de São José do Rio Preto tem colheita entre julho e dezembro. As demais regiões não colhem no período. $\mathrm{O}$ mesmo ocorre no Paraná. O zoneamento permite que o produtor adquira o crédito para as uvas de sequeiro apenas entre os meses de julho e dezembro, pois são os mais propícios para o cultivo. No entanto, a colheita das uvas paranaenses da safra principal se inicia em dezembro e pode se estender até fevereiro e a colheita da safra temporã (ou precoce/antes do tempo) vai de abril a julho. Já na Bahia e em Pernambuco, o zoneamento indica que o produtor pode cultivar a fruta durante o ano todo para a cultura irrigada (MAPA, 2015). Assim, a região do Vale do São Francisco (BA/PE) tem maior vantagem no que diz respeito ao período de obtenção dos recursos dos programas de crédito agrícola que tenham o enquadramento no zoneamento agrícola como um limitante.

Além disso, em alguns casos, o produtor tem que comprovar que tem capacidade de pagamento do financiamento e ser dependente da atividade agropecuária, ou seja, a maior renda da sua família deve vir da uva.

\footnotetext{
14 “O Zoneamento Agrícola de Risco Climático é um instrumento de política agrícola e gestão de riscos na agricultura. O estudo é elaborado com o objetivo de minimizar os riscos relacionados aos fenômenos climáticos e permite a cada município identificar a melhor época de plantio das culturas, nos diferentes tipos de solo e ciclos de cultivares“ (MAPA, 2015. Disponível em: http://www.agricultura.gov.br/politica-agricola/zoneamentoagricola).
} 
Na opinião de alguns agentes do setor ${ }^{15}$, porém, ainda falta crédito agrícola específico para a cultura da uva. $\mathrm{O}$ último dado de crédito agrícola detalhado por cultura disponível pelo Banco Central é de 2012. Naquele ano, foram destinados pouco mais de R 147 milhões para o custeio da uva de mesa em uma área de 5,4 mil hectares (BANCO CENTRAL DO BRASIL, 2012).

Quanto ao seguro rural, o produtor o adquire a fim de se proteger dos riscos causados pelas intempéries climáticas. Caso a lavoura seja atingida por chuvas fortes, granizos, geadas, secas, entre outros problemas climáticos, o produtor pode, através do seguro, recuperar parte do capital investido que foi perdido na lavoura. Geralmente, o seguro rural é contratado junto a uma seguradora privada e habilitada pelo Ministério da Agricultura. O Mapa oferece, ainda, através do Programa de Subvenção ao Prêmio do Seguro Rural (PSR), auxílio financeiro para contratação deste seguro. Este auxílio, para o ano safra 2014/15, tem valor programado de R \$ 700 milhões, o mesmo que no ano anterior. Porém, o produtor, para adquirir o PSR, não pode ter a cobertura do Proagro ou Proagro Mais para a mesma cultura na mesma área da propriedade (MAPA, 2015). Neste caso, o produtor tem que escolher entre o crédito e o seguro e, muitas vezes, acaba optando pelo primeiro, mais vantajoso, segundo os entrevistados deste trabalho.

No Brasil, há menos auxílio/programas para seguro rural frente ao crédito agrícola. Este cenário é ainda pior no caso de viticultores, que conseguem contratar seguro apenas contra granizo, no caso das adversidades. Assim, no caso de produtores que cultivem uva em locais onde não há problemas com granizo, não há o porquê de se adquirir seguro rural, como no Vale do São Francisco e na região de São José do Rio Preto (SP).

Além disso, pesquisando os tipos de seguro disponíveis para uva nas seguradoras privadas, a única opção disponível ao produtor de uva é para granizo. Com isso, muitos produtores deixam de adquirir o seguro para investir em tecnologia de campo - telas que protegem as uvas contra o granizo, como é o caso de muitos viticultores entrevistados nesta pesquisa. Os principais tipos de seguro passíveis de contratação pelo produtor de uva de mesa podem ser visualizados nos Apêndices $\mathrm{C}$ e D deste trabalho.

\footnotetext{
${ }^{15}$ Informação obtida nas entrevistas realizadas com produtores de uva.
} 


\subsubsection{Perfil dos produtores brasileiros de uva}

Para este trabalho, foram entrevistados 40 produtores de uva de mesa (tanto rústica quanto fina), de pequeno, médio e grande porte, localizados nas cinco regiões-alvo: Vale do São Francisco (BA/PE), região de São José do Rio Preto (SP), região Macro Metropolitana Paulista, região de Campinas (SP) e Norte do Paraná - sendo oito participantes em cada região.

O perfil dos produtores de uva de mesa entrevistados neste estudo, no geral, é bastante heterogêneo no que diz respeito ao tamanho da propriedade total e aos produtos cultivados. A menor propriedade é de 3,5 hectares, localizada na região de Campinas e a maior tem 2.354 hectares, localizada no Vale do São Francisco. Com relação à área apenas com a uva de mesa na propriedade, varia entre 1 hectare (região de Jales - SP) e 882 hectares, no Vale do São Francisco. Esta diferença já remete à ampla discrepância de gestão que há na produção de uva de mesa - desde uma gestão familiar até uma empresarial de grande porte. Além disso, $60 \%$ dos produtores cultiva outros produtos além da uva, não tendo monocultura. Os mais citados foram outras frutas como manga (principalmente no Nordeste), laranja, banana e frutas de caroço (principalmente em São Paulo) e pastagem (também em São Paulo). No Paraná, é mais comum ter grãos e cereais, além da uva.

Dos 40 entrevistados, apenas duas eram mulheres, mostrando que a presença feminina neste setor é bastante limitada no que diz respeito à produção. Abaixo, é detalhado o perfil dos produtores por região, sendo oito entrevistados em cada uma (Tabela 8).

A região que mais apresentou presença da agricultura familiar em relação à amostra deste trabalho foi a Macro Metropolitana Paulista, com 88\% de representatividade, considerando-se que os participantes da pesquisa são das cidades de São Miguel Arcanjo, Pilar do Sul e Porto Feliz. Para saber sobre a agricultura familiar, foi indagado se o produtor tinha acesso ao Pronaf.

Dos oito entrevistados da região de São José do Rio Preto, que tem a cidade de Jales como a principal representante, apenas 38\% disse se enquadrar na produção familiar - um produtor que não está nessa estatística de produção familiar disse que até se enquadraria pelo tamanho da propriedade, mas como tinha outro trabalho na cidade não poderia pegar os benefícios que outros produtores familiares têm. Porém, de acordo com a literatura, nesta região, há importante presença da agricultura familiar para a uva de mesa (TONDATO, 
2010), o que não foi verificado na amostra desta pesquisa. Tondato (2010) ainda relata que a uva de mesa tem extrema importância para a economia desta região.

Tabela 8: Perfil dos entrevistados de cada região produtora

\begin{tabular}{|c|c|c|c|c|c|c|c|}
\hline \multicolumn{8}{|c|}{ Perfil dos entrevistados por região } \\
\hline Região & $\begin{array}{c}\text { Área } \\
\text { média } \\
\text { total (ha) }\end{array}$ & $\begin{array}{c}\text { Área } \\
\text { média com } \\
\text { uva (ha) }\end{array}$ & $\begin{array}{c}\text { Mão de } \\
\text { obra/hectare }\end{array}$ & $\begin{array}{l}\text { Produtividade } \\
\text { média ( } t / h a)\end{array}$ & $\begin{array}{l}\text { Tempo na } \\
\text { atividade } \\
\text { (variação) }\end{array}$ & Variedades produzidas & $\begin{array}{c}\% \\
\text { produção } \\
\text { familiar }\end{array}$ \\
\hline Macro Metropolitana Paulista & 24,29 & 6,77 & 1,38 & 23,78 & $\begin{array}{c}\text { entre } 5 \text { e } 50 \\
\text { anos }\end{array}$ & $\begin{array}{c}\text { niagara, itália, rubi, } \\
\text { benitaka, brasil, red globe, } \\
\text { pilar moscato }\end{array}$ & $88 \%$ \\
\hline Norte do Paraná & 18,63 & 3,95 & 1,69 & 25,37 & $\begin{array}{l}\text { entre } 20 \text { e } \\
45 \text { anos }\end{array}$ & $\begin{array}{c}\text { niagara, itália, rubi, } \\
\text { benitaka, brasil, vitória, } \\
\text { núbia }\end{array}$ & $50 \%$ \\
\hline Região de Campinas (SP) & 22,6 & 12,07 & 0,93 & 15,75 & $\begin{array}{c}\text { entre } 20 \text { e } \\
122 \text { anos }\end{array}$ & niagara & $63 \%$ \\
\hline Região de São José do Rio Preto (SP) & 33,51 & 6,06 & 1,52 & 20,75 & $\begin{array}{c}\text { entre } 14 \text { e } \\
30 \text { anos }\end{array}$ & $\begin{array}{c}\text { niagara, itália, rubi, } \\
\text { benitaka, brasil, red globe }\end{array}$ & $38 \%$ \\
\hline Vale do São Francisco (BA/PE) & 777,66 & 184,06 & 3,51 & 33 & $\begin{array}{c}\text { entre } 5 \text { e } 33 \\
\text { anos }\end{array}$ & $\begin{array}{l}\text { itália melhorada, benitaka } \\
\text { melhorada, brasil, vitória, } \\
\text { festival, trompson, } \\
\text { crimson, midnight beauty, } \\
\text { aara } 15 \text {, sugar crispy, sofia, } \\
\text { regal, sugraone, cotton } \\
\text { candy, sweet } \\
\text { mayabelle,sweet } \\
\text { celebration, sweet } \\
\text { sapphire, seet sunshine, } \\
\text { timco, seet Jubilee }\end{array}$ & $0 \%$ \\
\hline
\end{tabular}

Fonte: Elaborado pela autora a partir de dados da pesquisa

Ainda em São Paulo, a região de Campinas também tem elevada porcentagem de agricultores familiares (63\%). No Paraná, também é forte a presença da agricultura familiar (50\% da amostra). Os estados do Sul ainda são conhecidos pela presença de cooperativas. Dentre os entrevistados, porém, poucos fazem parte das cooperativas, sendo que foram citadas duas: Comafrut (Cooperativa Marialvense dos Fruticultores), situada na cidade de Marialva, e a Cooperativa Agrícola Sul Brasil de Londrina - não foram encontradas mais informações sobre essas cooperativas.

Já no Nordeste, dois oito entrevistados, duas eram cooperativas. As cooperativas são fortes na região, principalmente para manter os pequenos e médios produtores na atividade de exportação de uva - se não fosse a cooperativa, provavelmente boa parte dos produtores não conseguiria exportar sozinhos, na opinião de entrevistados. Ainda segundo um entrevistado, o cooperativismo é muito importante para o desenvolvimento da fruticultura na região e da competitividade dos produtores cooperados por conta da presença de grandes empresas concorrentes no Vale. 
Em relação à produtividade no campo registrada pela amostra da pesquisa, esta reflete a amostra e, também, o portfólio das variedades cultivadas por cada um dos entrevistados, não podendo ser extrapolada como a real produtividade de toda a região. Em Campinas, tem-se o menor rendimento médio (15,75 toneladas/hectare). Isso porque a variedade rústica tem menor rendimento médio que as uvas finas. Pode-se relacionar esse dado, ainda, com a mão de obra/hectare, que também é a mais baixa nesta região - 0,93 trabalhador/hectare. Além disso, em Campinas também, as propriedades são mais antigas, tendo entre 20 e 122 anos muitas áreas com uva foram herdadas da família, passam de pai para filho há algumas gerações. Capello (2014) também estudou a uva niagara na região de Campinas na safra 2012/13 e encontrou, para uma propriedade de 4,5 hectares, 14 toneladas/hectare na safra principal (nov-dez) e 10 toneladas/hectare na safra temporã (mar-mai). Boa parte dos produtores da regional Campinas "nasceu na uva", tendo em vista que é uma cultura muito tradicional nesta região. E, em Campinas, produtores cultivam apenas a variedade rústica niagara, que tem rendimento mais baixo que o das uvas finas.

Capello (2014) estudou, ainda, a uva niagara nas regiões de São Miguel Arcanjo (incluído na Macro Metropolitana Paulista) na safra 2012/13 e Jales (região de São José do Rio Preto) na safra 2012. Na primeira região, Capello (2014) encontrou, para uma propriedade de 2 hectares, 22 toneladas/hectare na safra principal e 15 toneladas/hectare na safra temporã. Já em Jales, com safra única, registrou rendimento médio de 20 toneladas/hectare em uma área de 3,5 hectares com uva.

O maior índice de produtividade média é o do Vale do São Francisco (de 33 toneladas/hectare), onde também se tem a maior relação mão de obra/hectare - de 3,51, e também as fazendas mais novas e renovadas - onde os produtores prezam por retirar parreirais velhos e substituir por mais novos, prática que acontece com menor frequência em outras regiões. Essa prática estimula o aumento da produtividade - parreiras mais velhas produzem menos. Segundo pesquisadores do setor de uva ${ }^{16}$, essa região detém a melhor produtividade média brasileira pelo uso de mais tecnologias no campo.

Em relação à produtividade média encontrada na literatura, Deleo e colaboradores (2012) calcularam a produtividade média das uvas finas de mesa de propriedades de pequena, média e grande escala do Vale do São Francisco nos anos de 2008 e 2011. Nas pequenas propriedades de uva, de 12 hectares, o rendimento da thompson (sem semente) foi de 30 toneladas/hectare em 2008 e de 28 toneladas/hectare em 2011, enquanto o da itália melhorada

\footnotetext{
${ }^{16}$ A autora consultou pesquisadores e analistas de mercado de uva do Cepea.
} 
(com semente) foi de 48 toneladas/hectare em 2008 e 55 toneladas/hectare em 2011. Na média propriedade (área de 35 hectares) foi registrado 30 toneladas/hectare para a thompson em 2008 e 27 toneladas/hectare para esta variedade em 2011, enquanto a itália melhorada teve produtividade de 50 toneladas/hectare em 2008 e 52 toneladas/hectare em 2011. Por fim, na propriedade de grande escala (250 hectares), a thompson teve rendimento de 25 toneladas/hectare e 26,3 toneladas/hectare, em 2008 e 2011, respectivamente. Já a itália melhorada deste perfil de fazenda, teve produtividade de 39,8 toneladas/hectare em 2008 e 40 toneladas por hectare em 2011.

Outro ponto importante são as variedades de uva produzidas e ofertadas pelas regiões. Campinas produz apenas um tipo de uva - niagara. Em segundo lugar, aparece a região de São José do Rio Preto com produção de seis variedades, em seguida Macro Metropolitana Paulista e Norte do Paraná com sete e por fim, Vale do São Francisco com 20 variedades disponíveis para venda ao consumidor. A diversificação, como verificado por Cunha-Filho e Carvalho (2005), é um fator positivo em termos de competitividade, sobretudo na pauta das exportações - um mercado foco da região do Vale do São Francisco - e, além disso, torna o mercado mais atrativo para o consumidor. Segundo Grangeiro e colaboradores (2002), produtores de uva de mesa do Vale do São Francisco têm diversificado a produção com o intuito de não saturar o mercado com apenas uma variedade de uva, aumentando a opção de compra do consumidor.

\begin{tabular}{|c|c|c|c|c|c|c|c|c|c|c|c|c|c|}
\hline Safra & Região & Jan & Fev & Mar & Abr & Mai & Jun & Jul & Ago & Set & Out & Nov & Dez \\
\hline Safra principal & de Campinas & & & & & & & & & & & & \\
\hline Safrinha & de Campinas & & & & & & & & & & & & \\
\hline Safra principal & Porto Feliz & & & & & & & & & & & & \\
\hline Safrinha & Porto Feliz & & & & & & & & & & & & \\
\hline Safra única & $\begin{array}{c}\text { São Miguel Arcanjo e } \\
\text { Pilar do Sul }\end{array}$ & & & & & & & & & & & & \\
\hline Safra única & São José do Rio Preto & & & & & & & & & & & & \\
\hline $\begin{array}{c}\text { Colheita de uvas } \\
\text { com semente }\end{array}$ & Vale do São Francisco & & & & & & & & & & & & \\
\hline $\begin{array}{c}\text { Colheita de uvas } \\
\text { sem semente }\end{array}$ & Vale do São Francisco & & & & & & & & & & & & \\
\hline Safra principal & Paraná & & & & & & & & & & & & \\
\hline Safrinha (temporã) & Paraná & & & & & & & & & & & & \\
\hline
\end{tabular}

Figura 15: Calendário de colheita das regiões produtoras de uva de mesa

Fonte: Cepea (2014). 
Em relação ao período de produção, o da região Macro Metropolitana Paulista se subdivide entre as microrregiões: a de São Miguel Arcanjo e Pilar do Sul produzem de janeiro a abril e Porto Feliz de maio a junho. Esta última ainda tem safrinha (temporã) de novembro a dezembro. O Paraná e a região de Campinas produzem de novembro a janeiro. O Paraná, por sua vez, tem safra temporã de abril a junho e a região de Campinas tem colheita da safrinha de março a maio, também coincidindo. Vale ressaltar que a temporã geralmente tem melhores preços que a safra principal (Figura 15).

A região de São José do Rio Preto, por outro lado, tem safra única, que vai de julho a novembro. E o Vale do São Francisco produz o ano todo, com concentração de oferta no segundo semestre.

Apenas observando o perfil dos produtores/propriedades, pode-se concluir que a região de Campinas tem menor potencial competitivo e o Vale do São Francisco o maior.

\subsubsection{Comparação da competitividade das regiões produtoras de uva de mesa}

Com o auxílio do software Atlas.ti 7.0, as entrevistas foram analisadas e foram elaboradas três redes por região: a do ambiente institucional, a da tecnologia e a da comercialização, tendo em vista que são três grandes grupos de fatores que impactam na competitividade. A rede é um diagrama visual, pela qual se pode expressar e visualizar as relações entre os assuntos da entrevista. $\mathrm{Na}$ rede, as cores indicam o enraizamento (groundedness, que corresponde ao número de citações em que o código aparece, ou seja, sua frequência) e a densidade (número de conexões com outros códigos). Os códigos de alta densidade são indicados em vermelho, e os de alta frequência no azul. Além disso, os números entre parênteses ao lado de cada código também indicam enraizamento e densidade, respectivamente. As análises foram realizadas a partir de cada tópico (Ambiente Institucional, Tecnologia e Comercialização) para que as regiões fossem comparadas entre si.

- Ambiente Institucional

Nas redes do ambiente institucional, a da região Macro Metropolitana Paulista tem 19 códigos interligados, (Figura 16), a do Norte do PR tem uma rede com 22 códigos (Figura 17), a da região produtora de Campinas (Figura 18) contem 16 códigos, a de São José do Rio 
Preto (Figura 19) tem 19 códigos e, por fim, a do Vale do São Francisco tem apenas 14 códigos (Figura 20), sendo a menos robusta de todas as regiões analisadas neste trabalho.

O ambiente institucional, de um modo geral, tem impactado bastante na produção de uva, mesmo que não tão positivamente. Quando se analisa a assistência técnica e a participação das associações e cooperativas, o produtor é auxiliado apenas nas regiões do Norte do Paraná, de Campinas e, com mais intensidade, no Vale do São Francisco. Já em relação aos recursos do governo, o crédito é importante em todas as regiões. Mesmo que conseguir verba para financiar a lavoura seja um fator positivo, o produtor ainda reclama muito da burocracia e do valor, que poderia ser maior. Já para o seguro agrícola, foi considerado positivo apenas para a região de Campinas (SP), onde as prefeituras locais fornecem um subsídio adicional - o governo federal e o estadual também subsidiam o seguro, para todo o Brasil (Tabela 9).

Tabela 9: Comparação qualitativa do Ambiente Institucional das regiões produtoras de uva

\begin{tabular}{lcccc}
\hline \multicolumn{5}{c}{ Ambiente Institucional } \\
\hline & $\begin{array}{c}\text { Assistência } \\
\text { Técnica }\end{array}$ & $\begin{array}{c}\text { Associação/ } \\
\text { Cooperativa }\end{array}$ & Crédito Rural & $\begin{array}{c}\text { Seguro } \\
\text { Agrícola }\end{array}$ \\
\cline { 2 - 5 } Macro Metropolitana Paulista & - & - & + & - \\
Norte do Paraná & $-/+$ & - & + & - \\
Região de Campinas & + & - & + & + \\
Região de São José do Rio Preto & - & - & + & - \\
Vale do São Francisco & + & + & + & - \\
\hline
\end{tabular}

Analisando o ambiente da Macro Metropolitana Paulista, este é ineficiente e não auxilia o produtor em questões de competitividade e sobrevivência no setor. Na assistência técnica, o auxílio é deficitário e é prestado, em parte, pelas empresas de insumo e, parte, pelos agrônomos de associação e casas da agricultura local. Representantes das empresas de insumo aparecem apenas em início de safra, segundo os produtores, e estabelecem uma "política de troca", de modo informal: o produtor compra os insumos e os representantes fornecem auxílio. Já as associações fornecem auxílio financeiro para um técnico particular - o produtor paga uma porcentagem e, a associação, outra (mas o produtor nem sempre tem capital para desembolsar). No caso da casa de agricultura local, às vezes, a mesma promove cursos e os produtores reconhecem o bom trabalho do agrônomo. Porém, ainda falta verba pública para que o apoio seja mais eficiente. Em relação aos órgãos públicos, a Embrapa não é atuante na 
assistência. Quanto às associações/cooperativas, a maioria dos participantes desta região faz parte de alguma, porém, nem sempre é de uva - foi citada a participação em cooperativas e associações de grandes culturas, como a cana-de-açúcar.

A assistência técnica é mais complexa no Paraná do que na região paulista descrita anteriormente. Nesta, a associação/cooperativa é relacionada com falta de gestão e verba para o bom andamento e, também, não traz muitos benefícios aos produtores em questões de comercialização. Algumas cooperativas fecharam na região por dificuldade de se estabelecer no mercado, tendo em vista que os atacadistas/atravessadores fizeram forte pressão de concorrência. No Paraná, a maioria dos produtores tem assistência particular, ou seja, contrata um especialista para dar apoio técnico, tendo em vista que a assistência pública e gratuita não é bem avaliada e disponível. Há muito descontentamento com os órgãos públicos no Norte do PR. De acordo com o relato de um produtor, “a Emater, no passado, fomentou a produção de uva de mesa local, o que fez a área em produção aumentar". No entanto, esse trabalho cessou por falta de verba, e atualmente existem projetos e programas de apoio ao pequeno produtor com parceria do Sebrae, apenas para capacitação da mão de obra.

Na região de Campinas, o que mais chama a atenção é a forte presença do órgão público local. A Secretaria de Agricultura, principalmente da cidade de Louveira, auxilia os produtores até mesmo dos municípios vizinhos. Muitos produtores citaram que a assistência técnica é boa e a pessoa responsável tem conhecimento prático sobre a cultura - nas palavras de um produtor: "não adianta saber só na teoria". Há incentivos de algumas prefeituras desta região para o cultivo de uva e de outras frutas, já que a região de Campinas está no circuito paulista das frutas. O IAC (Instituto Agronômico de Campinas) fornece material genético aos produtores. Os demais órgãos públicos, como Embrapa e Cati, por outro lado, não são atuantes na região. Em relação às associações, poucos produtores fazem parte, e quando são associados, reclamam bastante da falta de apoio.

Um ponto importante nesta região é a tradição da cultura. Boa parte dos produtores "nasceu na uva", tendo em vista que é uma cultura muito tradicional nesta região, e quando eles têm algumas dúvidas técnicas, muitas vezes consultam livros, e até a internet.

Na região de São José do Rio Preto, as associações/cooperativas não apoiam muito o produtor em questões institucionais. Atualmente, parte dos produtores faz parte de uma cooperativa que está há mais de 15 anos no mercado, mas não atua apenas com uva. A cooperativa basicamente comercializa os produtos. A assistência técnica, por sua vez, é fraca na região. Segundo relato dos entrevistados, $80 \%$ dos produtores trabalham sem assistência periódica - eles mesmos fazem testes nas propriedades, conversam com vizinhos etc. Uma 
das únicas formas de assistência na região é da empresa de insumos, mas que auxilia apenas quando o produtor compra os produtos da revenda. Alguns citaram que, em 2015, tem havido um cadastro para um programa de assistência técnica que será fornecida para a agricultura familiar, o intuito é auxiliar o produtor por três anos - porém, ainda está em fase de inscrição. Quanto à prestação de auxílio pelos órgãos públicos, falta apoio. Produtores relataram que lutaram para levar a Embrapa para a região, onde este órgão tem um escritório regional. Porém, para os produtores, não há auxílio - a Embrapa atua na área de pesquisa, relacionada ao melhoramento genético.

No Vale do São Francisco, o cooperativismo é mais forte, sobretudo para que pequenos e médios produtores se mantenham no setor - já que esta região é marcada pela forte presença de grandes investidores e empresas de uva de mesa. Segundo entrevistados desta região, existem quatro cooperativas de sucesso, que auxiliam o produtor sobretudo em questões mercadológicas - compra de insumos, garantindo maior barganha, e venda de produto final, fazendo bom volume para venda. Essas cooperativas, porém, não trabalham apenas com uva de mesa, mas também com outras frutas. No geral, nenhuma grande empresa faz parte de cooperativas ou associações. Já em relação à assistência técnica, praticamente $100 \%$ dos entrevistados tem um consultor particular contratado. A Embrapa, apesar de presente na região, não faz esse tipo de trabalho.

Em relação à crédito rural e seguro agrícola, há grande semelhança entre as regiões, e a grande maioria dos entrevistados considera o crédito um bom recurso, tanto de investimento quanto de custeio, e que traz benefícios ao produtor. Boa parte relatou conseguir auxílio pelo Pronaf, tendo em vista a forte presença da agricultura familiar para uva de mesa. Para os produtores, o custeio é importante, mas o crédito para investimento garante ao produtor recursos para financiar máquinas, estrutura do parreiral - bens mais caros para a produção de uva de mesa. O produtor relata, ainda, que conseguir o crédito é até fácil, seja em banco público ou privado. Mesmo assim, ainda é bastante burocrático.

Por outro lado, para o seguro, a relação custo $x$ benefício não é atrativa para o produtor participante da pesquisa, em praticamente todas as regiões analisadas. A maioria relatou que só existe seguro contra granizo, como foi constatado no levantamento do ambiente institucional no item 4.1.1. deste trabalho. Ainda foi relatado que a franquia só paga parte do prejuízo ao produtor, se ele perder $100 \%$ das frutas. Não há pagamento se o granizo destruir a folha da planta, por exemplo, o que também causa perdas no campo. Um produtor da região Macro Metropolitana Paulista relatou: “... o seguro? Parei para uva. Não estava compensando - teve um ano que perdi $100 \%$ da produção por causa do granizo, e o seguro só cobriu $60 \%$. 
Então, estou investindo em telas contra granizo (que protege contra passarinhos também). São cinco anos para financiar, mas que vale mais a pena do que o seguro".

Além deste cenário, o produtor só consegue fazer o seguro com o auxílio do governo, o PSR, e mesmo assim não traz muitas vantagens, segundo eles. Nas regiões de São José do Rio Preto e do Vale do São Francisco, foi constatada a menor adesão ao seguro, tendo em vista que o clima nas duas regiões não é propício ao risco de granizo. A exceção é a região de Campinas, onde todos utilizam o seguro agrícola. A região é muito suscetível a granizo, sendo, portanto, o seguro necessário ao produtor, tendo em vista que poucos possuem tela de proteção. Para contratar o seguro, ainda, além do subsídio dos governos federal e estadual, a prefeitura de Louveira também apoia o produtor. Já em Indaiatuba, a pressão imobiliária é forte, e a prefeitura não presta auxílio.

Abaixo, visualizam-se as redes do ambiente institucional de cada região produtora.

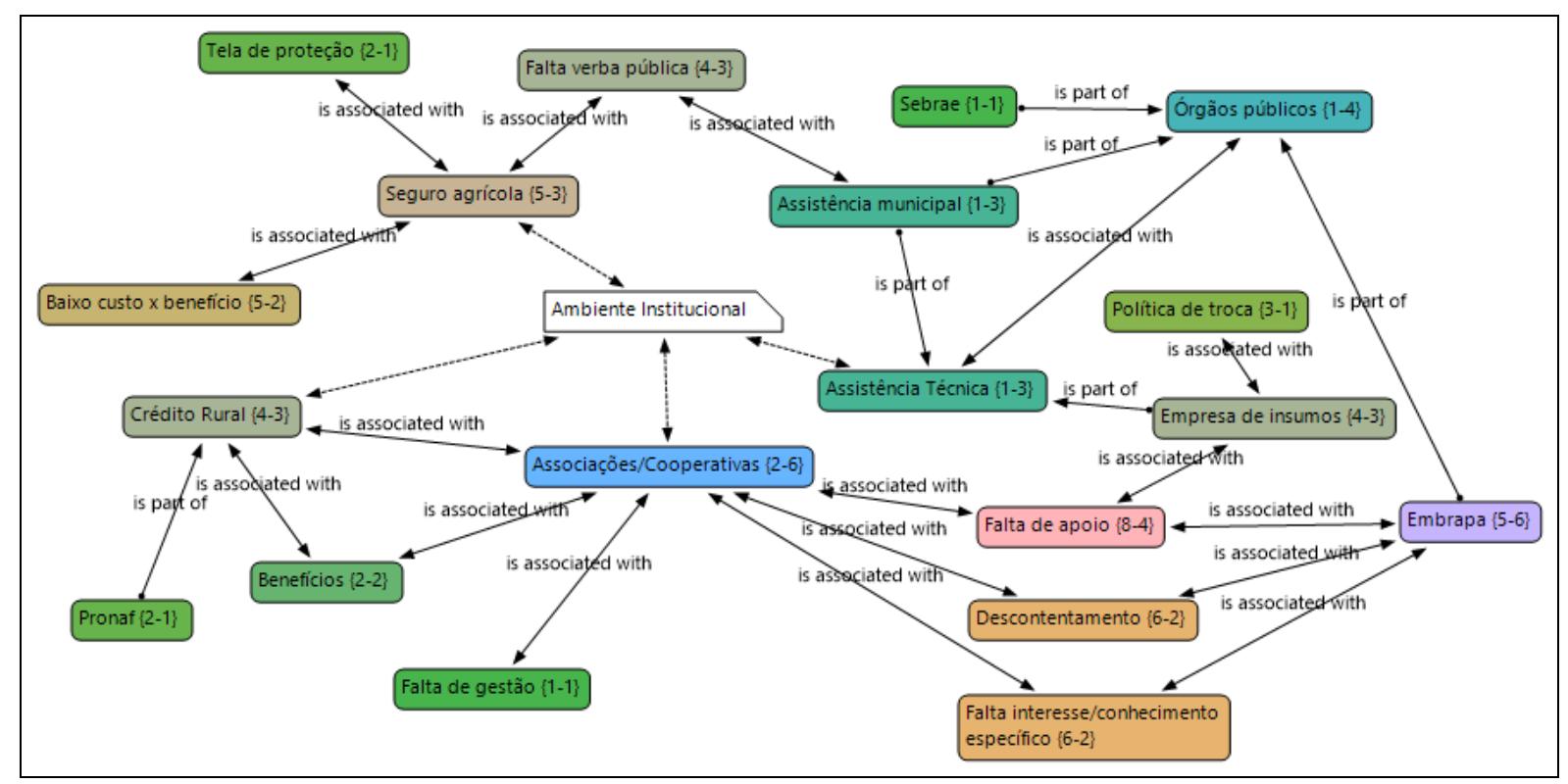

Figura 16: Rede do Ambiente Institucional da regional Macro Metropolitana Paulista 


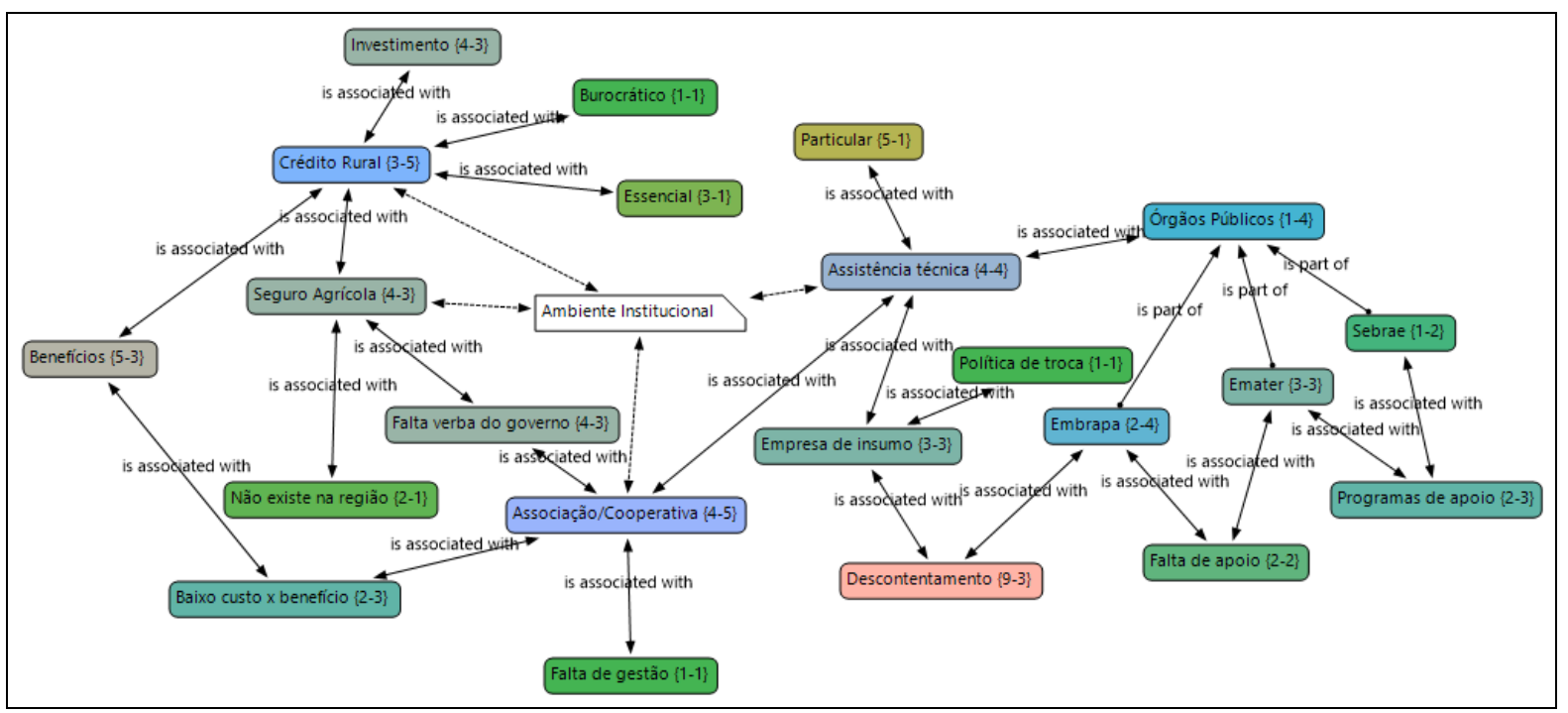

Figura 17: Rede do Ambiente Institucional da região Norte do Paraná

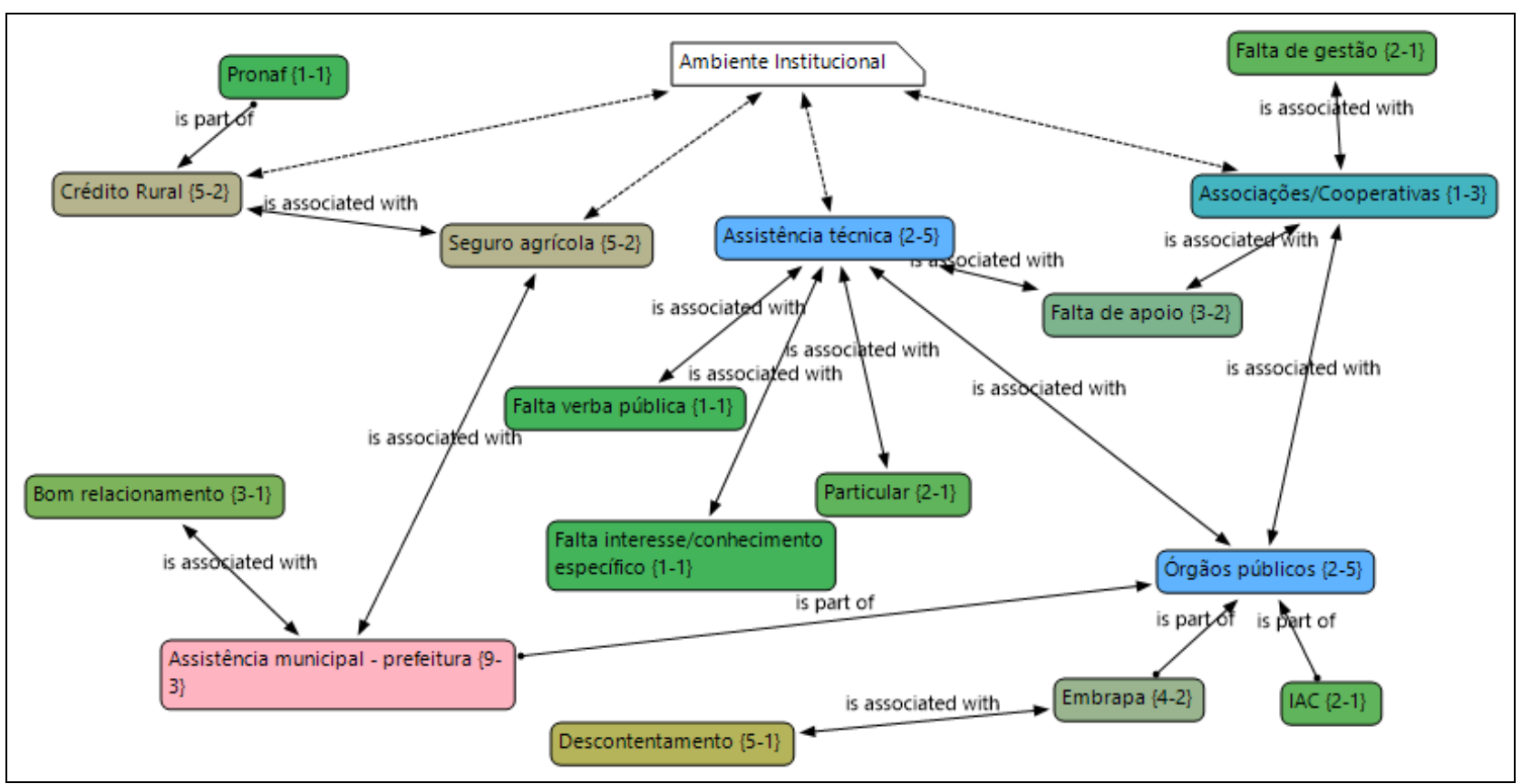

Figura 18: Rede do Ambiente Institucional da região de Campinas 


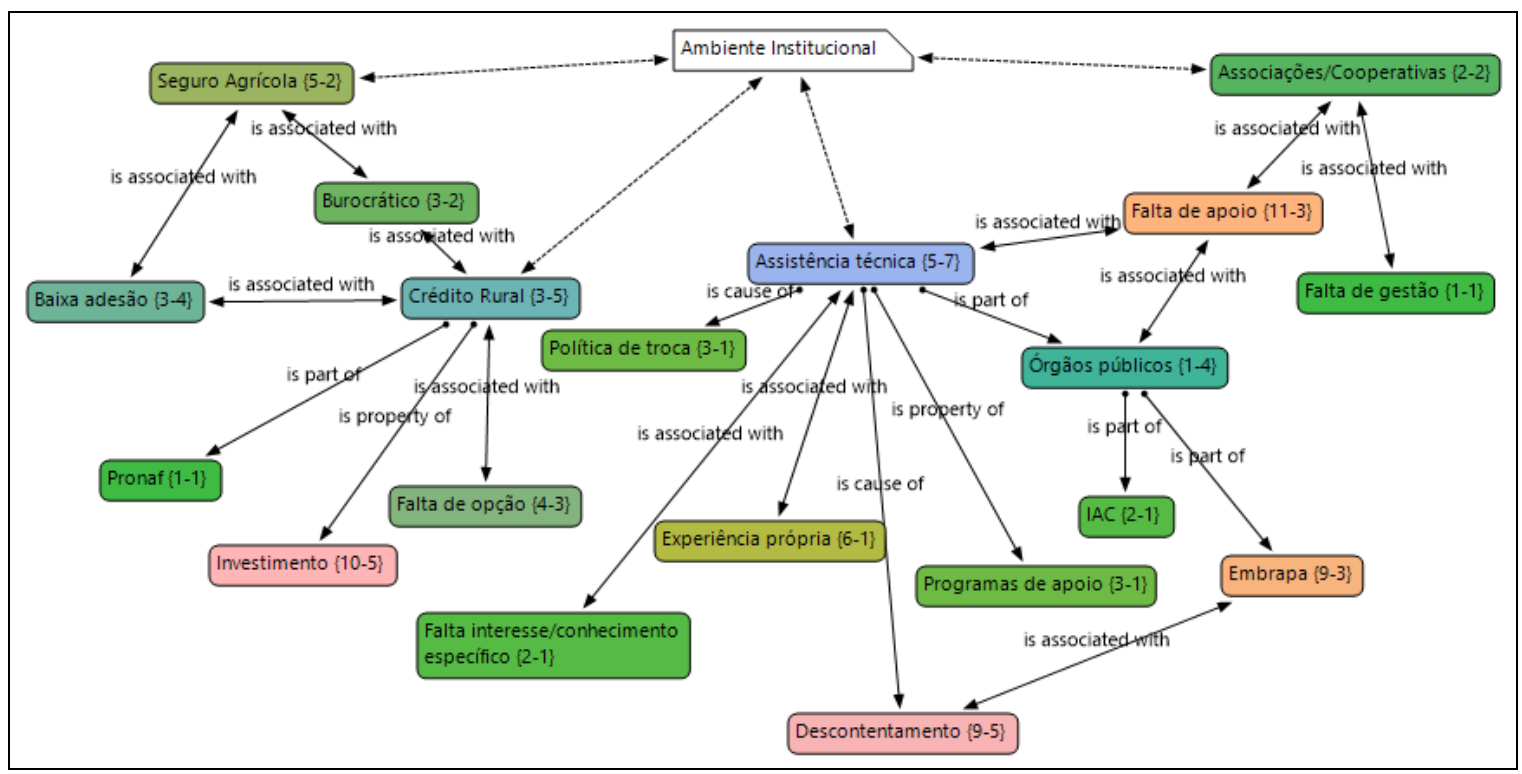

Figura 19: Rede do Ambiente Institucional da regional São José do Rio Preto (SP)

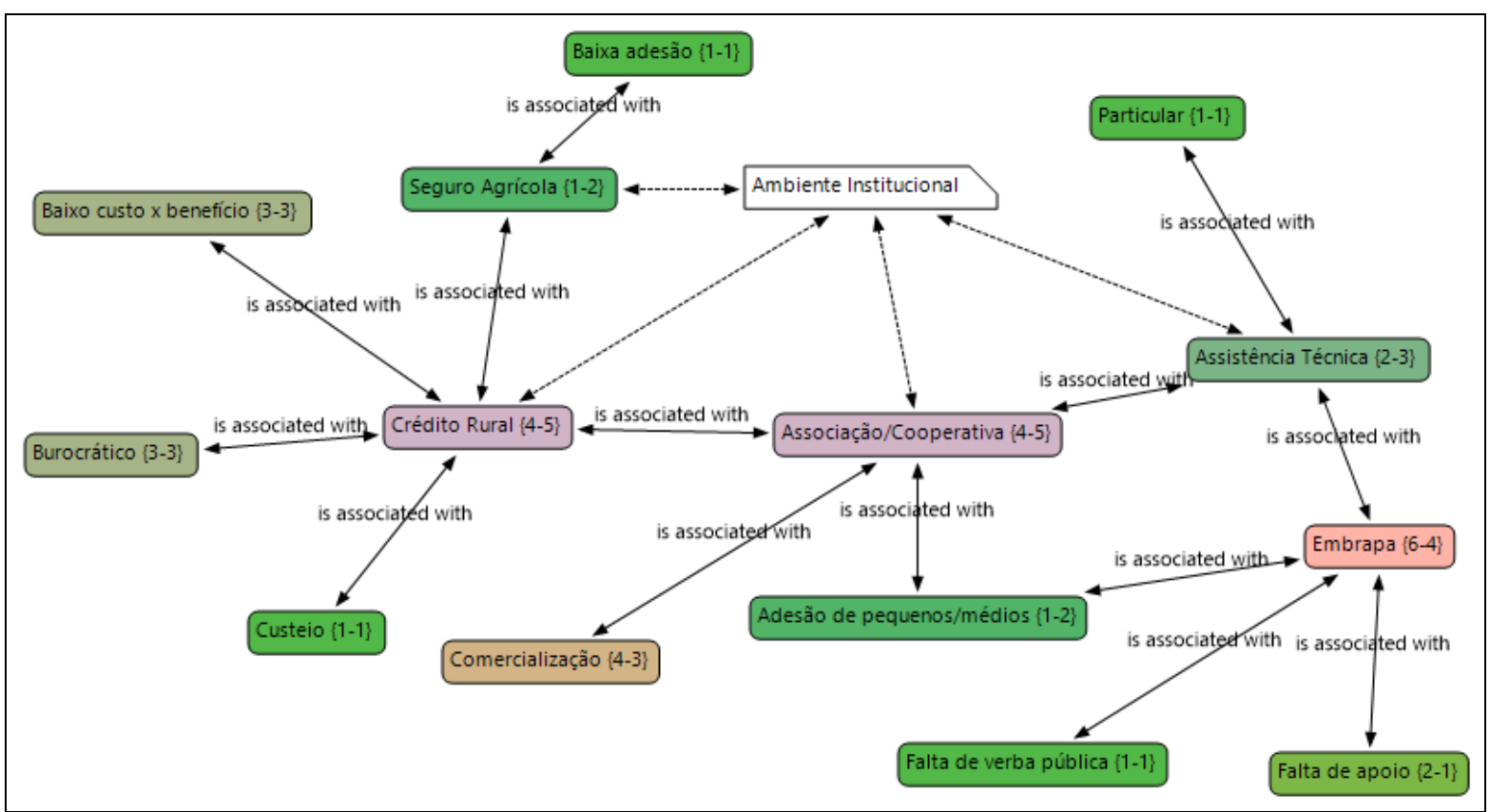

Figura 20: Rede do Ambiente Institucional da região do Vale do São Francisco

\section{- Tecnologia}

Nas redes de tecnologia, a da região Macro Metropolitana Paulista (Figura 21) e a do Norte do Paraná (Figura 22) têm 24 códigos cada, mas mesmo assim contam com algumas diferenças. A rede da região de Campinas conta com 22 códigos (Figura 23), a de São José do Rio Preto (Figura 24) tem 21 códigos e a do Vale do São Francisco (Figura 25), 24 códigos. Para esta parte do questionário, foi indagado sobre as questões de irrigação, atividades 
mecanizadas na lavoura e sobre o melhoramento genético, tendo em vista que esses são os principais fatores tecnológicos que afetam o custo, a qualidade e a produtividade do parreiral.

Quando se fala em tecnologia para uva de mesa, se traduz basicamente em ganho de produtividade e qualidade. Para isso, são utilizados equipamentos para auxiliar as atividades de campo (muito diferente das grandes máquinas agrícolas que são usadas para soja, por exemplo) e melhoramento genético - novas variedades de uva, como as resistentes a pragas e doenças. Das regiões analisadas, a do Vale do São Francisco é a mais avançada em relação ao progresso tecnológico, e a de Campinas a menos "tecnificada" (Tabela 10).

Tabela 10: Comparação qualitativa do nível tecnológico das regiões produtoras de uva

\begin{tabular}{lccc}
\hline \multicolumn{3}{c}{ Tecnologia } & \\
\hline & Irrigação & $\begin{array}{c}\text { Atividades } \\
\text { mecanizadas }\end{array}$ & $\begin{array}{c}\text { Melhoramento } \\
\text { Genético }\end{array}$ \\
\cline { 2 - 4 } Macro Metropolitana Paulista & - & $-/+$ & $-/+$ \\
Norte do Paraná & - & $-/+$ & $-/+$ \\
Região de Campinas & - & - & - \\
Região de São José do Rio Preto & + & - & - \\
Vale do São Francisco & + & + & + \\
\hline
\end{tabular}

Quanto à irrigação, apenas o Nordeste e a região de São José do Rio Preto são adeptas (100\% dos parreirais), sobretudo por conta do clima - sem irrigação não se produz frutas nestas regiões, que detém os sistemas mais eficientes e de mais alta tecnologia no mercado, gotejamento e microaspersão. Esses sistemas reduzem o consumo excessivo de água, já que a irrigação é localizada e permite a fertirrigação, ou seja, nutrição da planta através da água, que pode garantir maior produtividade. Nas outras regiões, a irrigação não é muito utilizada por conta do bom volume de chuva. Porém, mesmo com o regime de chuvas das regiões paulistas Macro Metropolitana e Campinas e do Paraná, a utilização da irrigação poderia garantir melhor produtividade.

Em um parreiral, algumas atividades básicas são passíveis de mecanização (roçada, pulverização, adubação e transporte de frutas na colheita), porém, a maioria das atividades ainda é feita manualmente (poda, amarrio, raleio, e colheita). Na região do Vale do São Francisco, praticamente todos os produtores mecanizam, ao máximo, as atividades básicas; boa parte dos produtores da Macro Metropolitana Paulista e do Norte do PR também consegue mecanizar as atividades básicas. Porém, um problema enfrentado é a adaptação do maquinário. Em regiões onde prevalece o sistema de condução latada, como é o caso dessas 
acima, a mecanização é um pouco mais difícil e há pouco maquinário no mercado que atenda às exigências. A região do Vale, por outro lado, tem conseguido investir em maquinários, o que é um pouco mais difícil nas outras regiões. No Vale, os produtores também estão testando (alguns já usando) máquinas que embalam a uva na cumbuca automaticamente na packing house. No geral, produtores do Nordeste vão buscar tecnologia fora do Brasil para suprir as necessidades.

Já na região de Campinas e na de São José do Rio Preto, é menor o número de adeptos da mecanização das atividades básicas, por causa da forte presença da agricultura familiar. Nestas regiões, o sistema em espaldeira está sendo trocado pelo $\mathrm{Y}$ devido à dificuldade de mecanizar o primeiro. Alguns produtores já têm usado pequenos tratores para pulverizar a cultura, deixando de lado os pulverizadores costais - espécie de "mochila" com o produto químico que o trabalhador leva nas costas. Outros fazem roçadas mecanizadas. A região de São José do Rio Preto ainda tem maior dificuldade por conta também do sistema de condução em latada, mas a grande maioria já tem investido em tratores de pequeno porte para auxiliar na lavoura.

Vale lembrar também, que, de um modo geral, para as atividades essencialmente manuais, o produtor tem tido problemas - a mão de obra está cada vez mais escassa, cara e sem especialização. Assim, não somente na região de Campinas, mas em todas outras há produtores investindo e fazendo testes com a condução em Y por conta da falta de mão de obra. Alguns citaram que o Y garante melhor produtividade e facilita em $80 \%$ a mecanização do parreiral, que á a busca constante dos produtores. O investimento em Y, ainda, é feito para garantir melhor qualidade da uva, frente à condução por espaldeira, e melhor produtividade da mão de obra. Porém, o sistema latada é ainda mais produtivo (em toneladas/hectare) que o Y para as uvas finas, o que limita maiores investimentos na troca desse sistema. Conforme as palavras de um produtor: "fazemos de tudo para depender menos da mão de obra". O aumento da mecanização tem sido uma saída para diminuir o número de trabalhadores contratados.

Quando indagados sobre melhoramento genético, "novas variedades" é um tema unânime. Porém, a maioria está em consenso no que diz respeito à falta de atuação da Embrapa. Produtores do Paraná até relataram que existe uma nova variedade da Embrapa que tem sido plantada na região, a uva fina de mesa núbia, porém, mesmo para o pequeno produtor a Embrapa vende a muda a um preço pouco atrativo - $\mathrm{R} \$ 8,00$.

Assim, produtores do Vale do São Francisco, além das parcerias coma Embrapa, que faz testes dentro das propriedades, buscam material genético fora do País, e acabam trazendo dos EUA, África do Sul e Espanha, individualmente, e pagando royalties. Para os exportadores, as 
novas variedades vão garantir o futuro dos embarques, tendo em vista que as mais tradicionais vão ficar restritas ao mercado interno. Outra região que tem investido em uma nova variedade é a Macro Metropolitana Paulista, mais precisamente no município de Pilar do Sul - a variedade é a "pilar moscato", desenvolvida localmente, é doce e sem semente, sendo vendida como uva gourmet e com preço muito acima do mercado.

Para as outras regiões, os próprios produtores fazem testes em suas propriedades, trocam mudas entre os vizinhos, buscando produzir uma fruta de melhor aparência.

O melhoramento ainda está muito relacionado com a qualidade, segundo os produtores entrevistados. Além disso, para garantir a qualidade, produtores dizem que o ideal é investir em adubação e manejo, com pós-colheita eficiente, classificando a fruta, o que ainda não existe para a uva de mesa no Brasil: um padrão de classificação brasileiro. A qualidade também depende muito da mão de obra na opinião deles: se não tiver funcionário suficiente e eficiente para fazer todos os tratamentos adequadamente e na hora certa, a uva pode ser prejudicada. Para os produtores paranaenses, porém, o clima é um fator que eles não conseguem controlar, mas que impacta muito na qualidade.

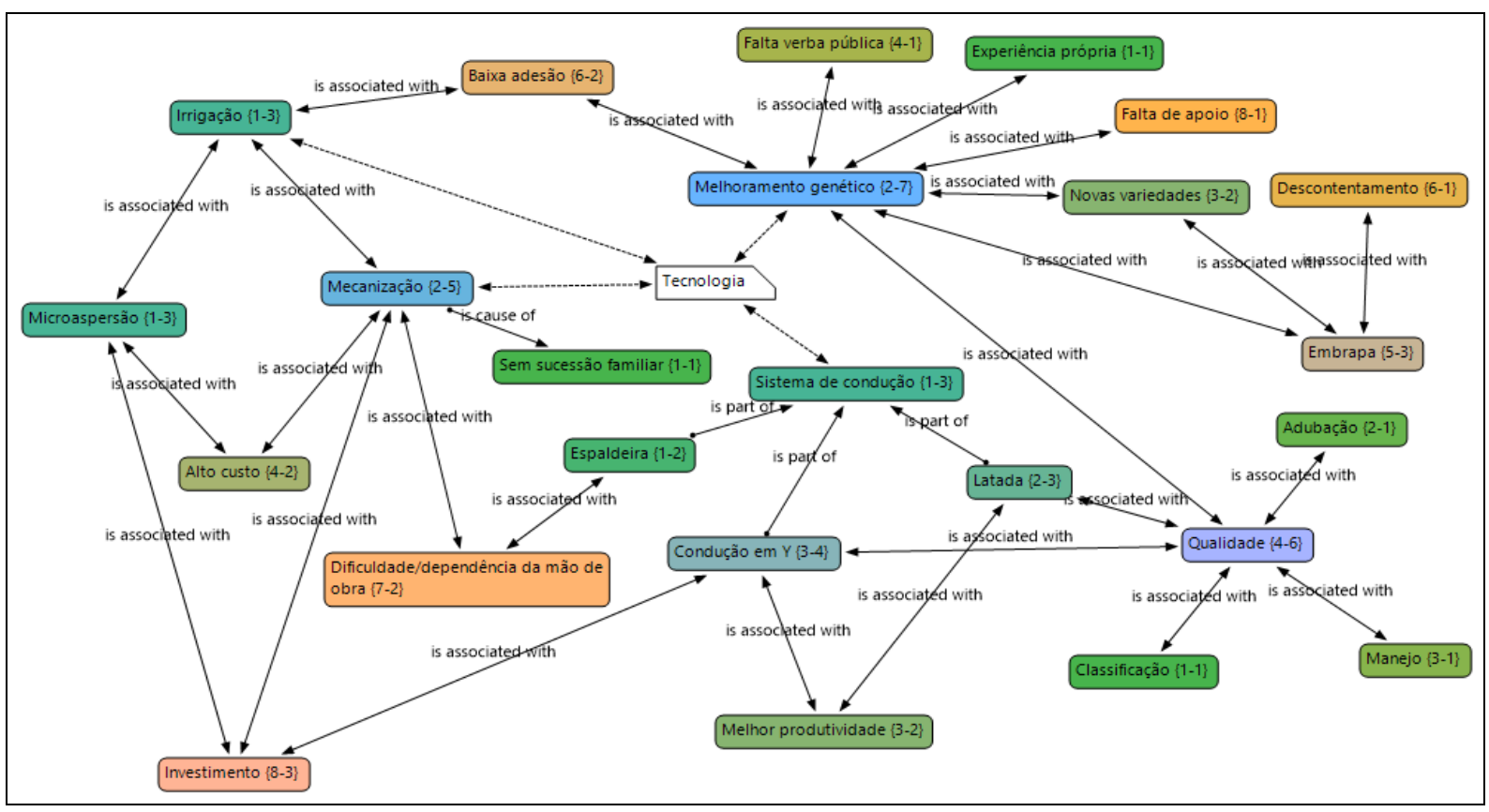

Figura 21: Rede da Tecnologia da regional Macro Metropolitana Paulista 


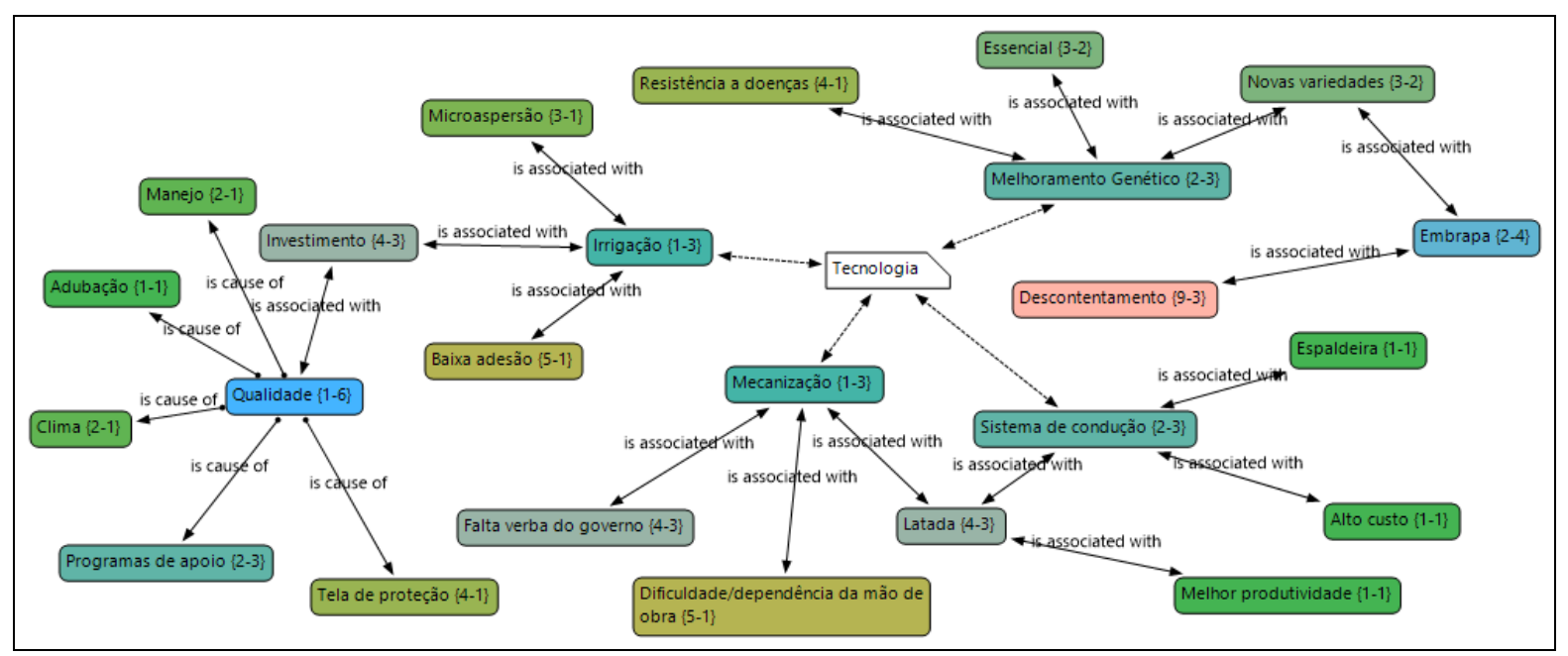

Figura 22: Rede da Tecnologia da região Norte do Paraná

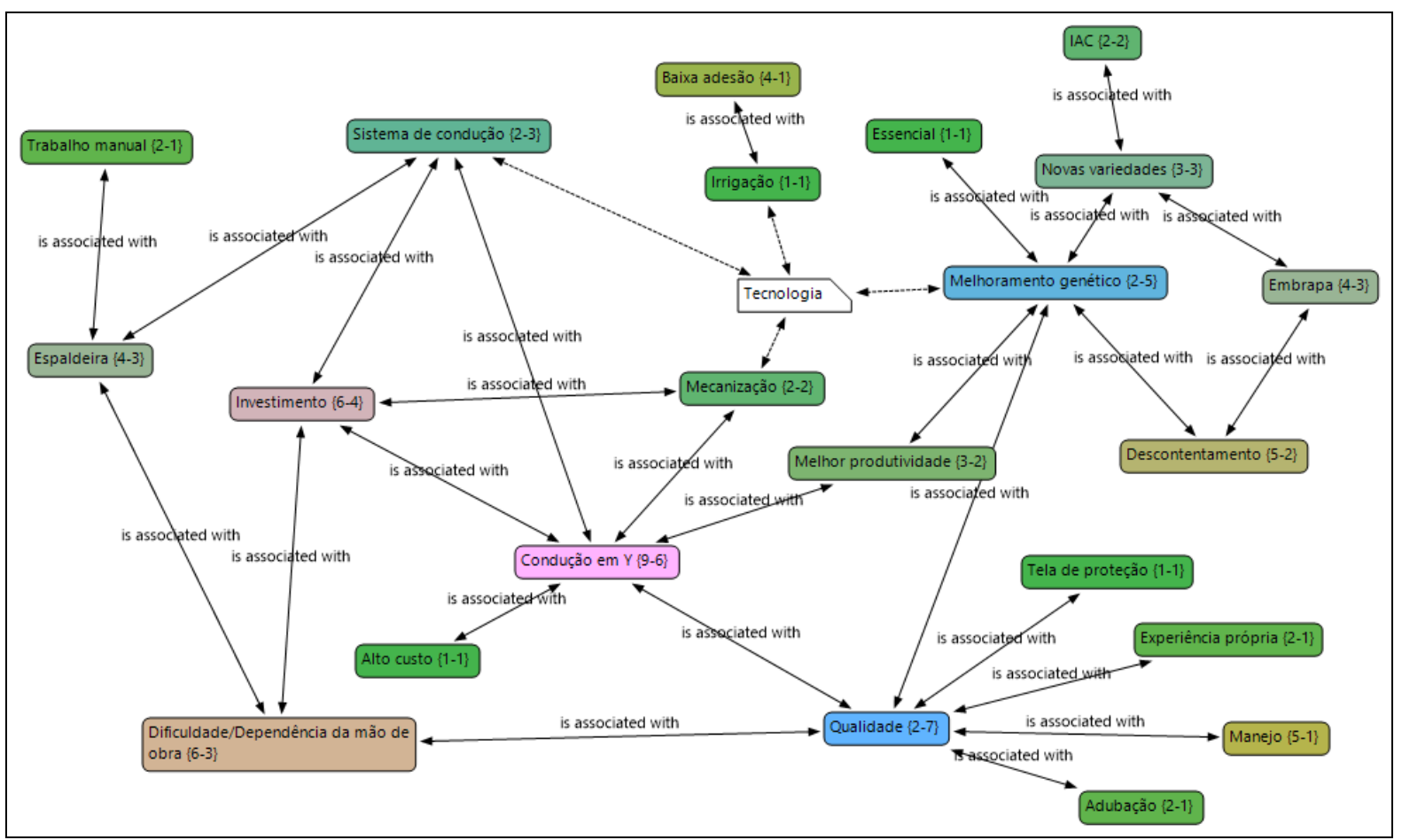

Figura 23: Rede da Tecnologia da região de Campinas 


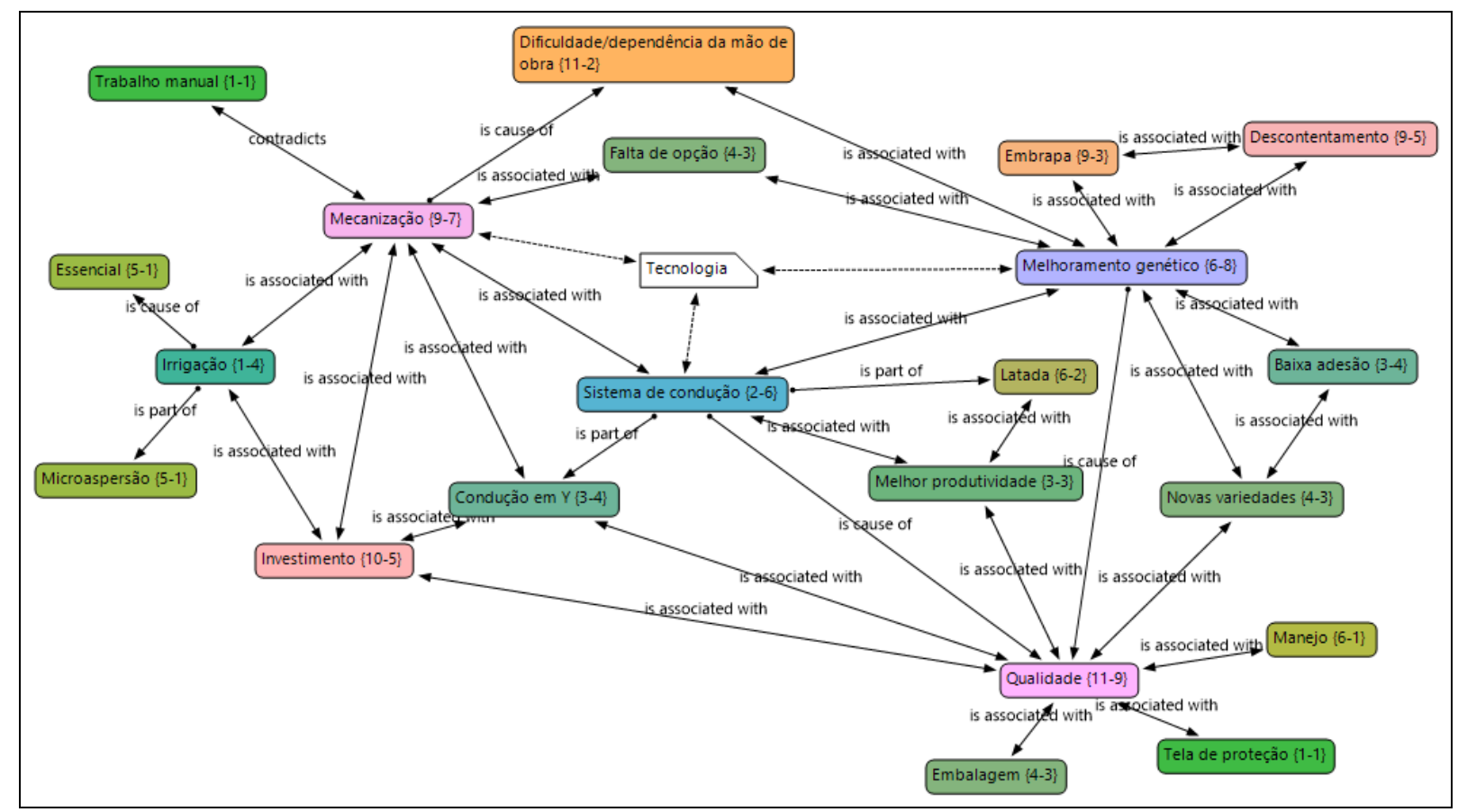

Figura 24: Rede da Tecnologia da regional São José do Rio Preto (SP)

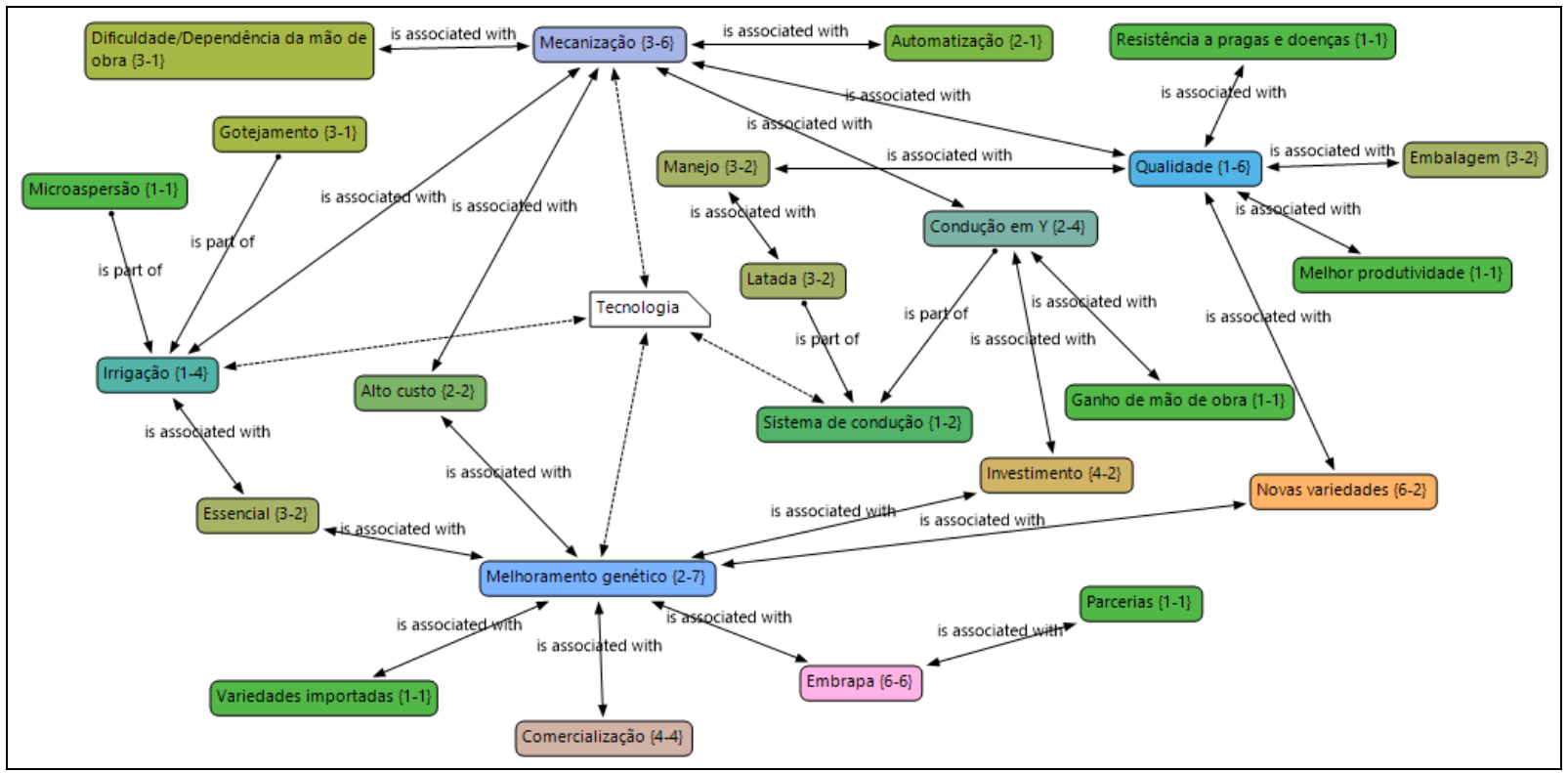

Figura 25: Rede da Tecnologia da região do Vale do São Francisco

\section{- Comercialização}

Na última rede, a da comercialização, a da região Macro Metropolitana Paulista (Figura 26) conta com 11 códigos, a do Norte do PR (Figura 27), 12 códigos, a de Campinas (Figura 28) possui 10 códigos, a de São José do Rio Preto (Figura 29) é a mais simples, com apenas oito códigos e a do Vale do São Francisco (Figura 30) é bem mais complexa do que a das outras regiões, contendo 19 códigos. A forma da negociação e venda da uva pelo produtor 
pode continuar garantindo a competitividade, ou reduzi-la. No geral, a região mais competitiva na comercialização é a do Vale do São Francisco (Tabela 11), única região, também, a exportar a uva de mesa.

Tabela 11: Comparação qualitativa da comercialização das regiões produtoras de uva

\begin{tabular}{lcccc}
\hline \multicolumn{5}{c}{ Comercialização } \\
\hline & Embalagem & $\begin{array}{c}\text { Logística } \\
\text { (refrigerada) }\end{array}$ & $\begin{array}{c}\text { Contrato de } \\
\text { venda }\end{array}$ & Exportação \\
\cline { 2 - 5 } Macro Metropolitana Paulista & $-/+$ & - & - & - \\
Norte do Paraná & $-/+$ & - & - & - \\
Região de Campinas & - & - & - & - \\
Região de São José do Rio Preto & $-/+$ & - & - & - \\
Vale do São Francisco & + & + & + & + \\
\hline
\end{tabular}

A rede de comercialização das regiões Macro Metropolitana Paulista, Norte do Paraná, Campinas e São José do Rio Preto é bastante semelhante, mostrando que não há grande diferença de competitividade neste quesito - há diferença apenas no período de venda no mercado (safra). A região de São José do Rio Preto oferta maior volume entre agosto e outubro, quando essas regiões supracitadas não conseguem colher a uva. Assim, produtores dessa região garantem competitividade de mercado. Neste período, concorrem também com a fruta do Vale do São Francisco, mas que tem maior foco na exportação nesses meses.

A uva dessas regiões citadas acima é comercializada basicamente com atacadistas e atravessadores. Nesta negociação, não há contrato e o produtor reclama muito do custo $x$ benefício da venda. Como a venda é spot, a melhor oportunidade que aparecer é a realizada. Como são regiões compostas basicamente por pequenos produtores, para a maioria, os compradores vão buscar as uvas nas propriedades, tendo em vista que não conseguem ofertar um grande volume para que possam comercializar sem a presença do atravessador. Este cenário já havia sido constatado por Barros e Boteon em 2002. No geral, produtores destas regiões são descontentes com a comercialização e relatam que não sabem o que fazer para melhorar.

Porém, existem algumas particularidades. Na região de Campinas está crescendo muito o turismo rural - por estar no circuito paulista das frutas, produtores se beneficiam da presença dos turistas. O turismo ocorre em épocas mais calmas de trabalho no campo, mas que ainda tenham frutas nas parreiras para serem colhidas. O turista agenda a visita na 
propriedade e, segundo produtores: "colhe a própria uva, pesa e paga por ela ... e a gente ainda economiza na mão de obra".

O destino final da uva de cada região também é diferente, atingindo os mais diversos estados do Brasil. Nas regiões Macro Metropolitana Paulista, Norte do Paraná e São José do Rio Preto, o comprador ainda fornece embalagens, e às vezes, o produtor tem sua marca própria, o que pode favorecer a venda.

Já o Nordeste é bem diferente das demais regiões - o volume comercializado individualmente é maior, seja produtor ou via cooperativa. A maior parte dos produtores ainda exporta a uva, sendo que a participação do mercado externo nas vendas variou de $20 \%$ a $40 \%$ entre os respondentes da pesquisa. No mercado de exportação, antigamente o contrato era para envio da fruta consignada, e o produtor recebia apenas após um ou dois meses de finalizado o embarque. Este tipo de transação está mudando - produtores têm fechado contratos de volume e preço, sobretudo com novos clientes e supermercados estrangeiros.

$\mathrm{Na}$ venda ao mercado interno, não há contrato com o atacado, assim como nas outras regiões produtoras, e muitas vezes, as ceasas do Sudeste tem baixo custo $x$ benefício, principalmente porque o frete é pago pelo produtor. Por outro lado, a venda para os supermercados do Brasil, sobretudo para as grandes redes, apesar de ser mais burocrático e exigente em qualidade, pode ser mais vantajoso. A venda é feita a partir de contrato fechado e o preço é estável durante o ano - o que garante sempre rentabilidade positiva e o produtor foge das flutuações de preço do mercado. Além disso, é o comprador quem paga o frete. No geral, o transporte da uva do Nordeste até as outras regiões do Brasil é feito sob refrigeração.

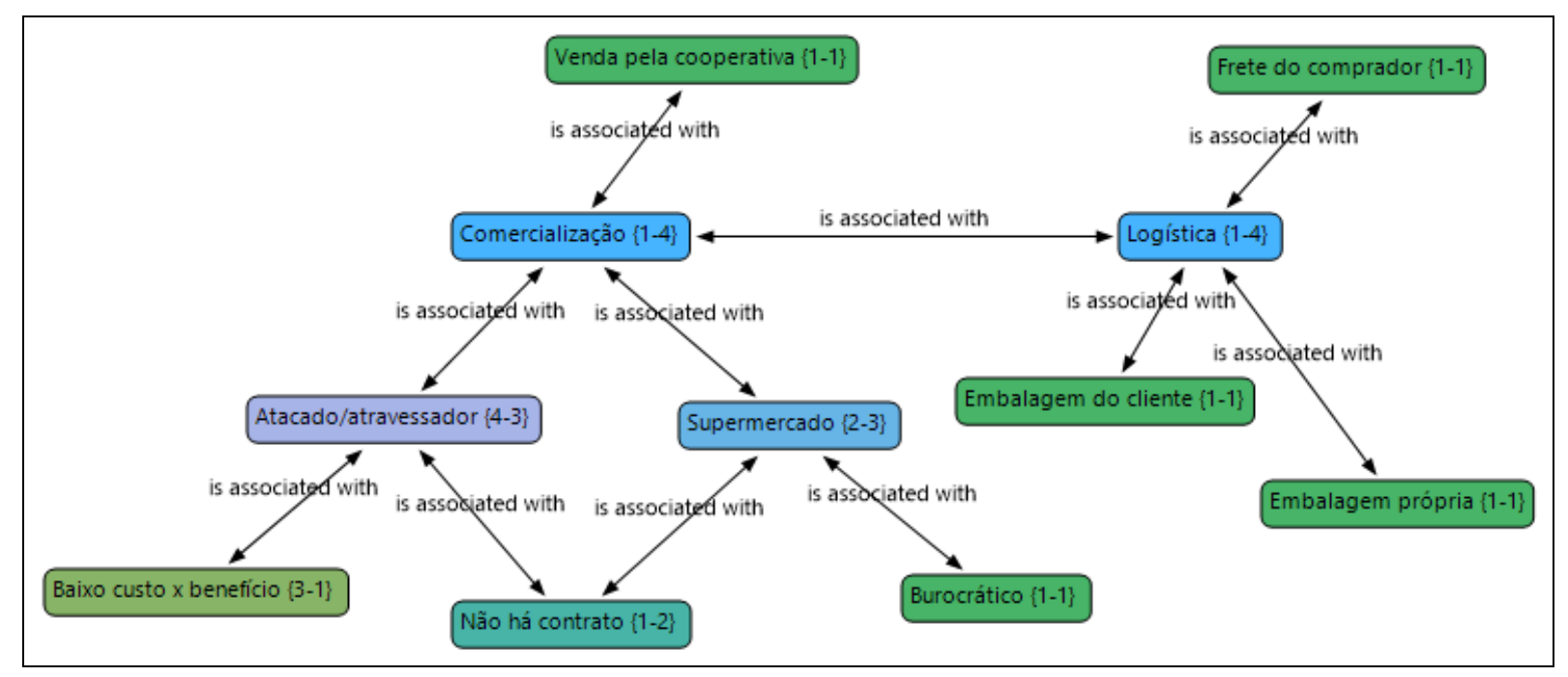

Figura 26: Rede da Comercialização da regional Macro Metropolitana Paulista 


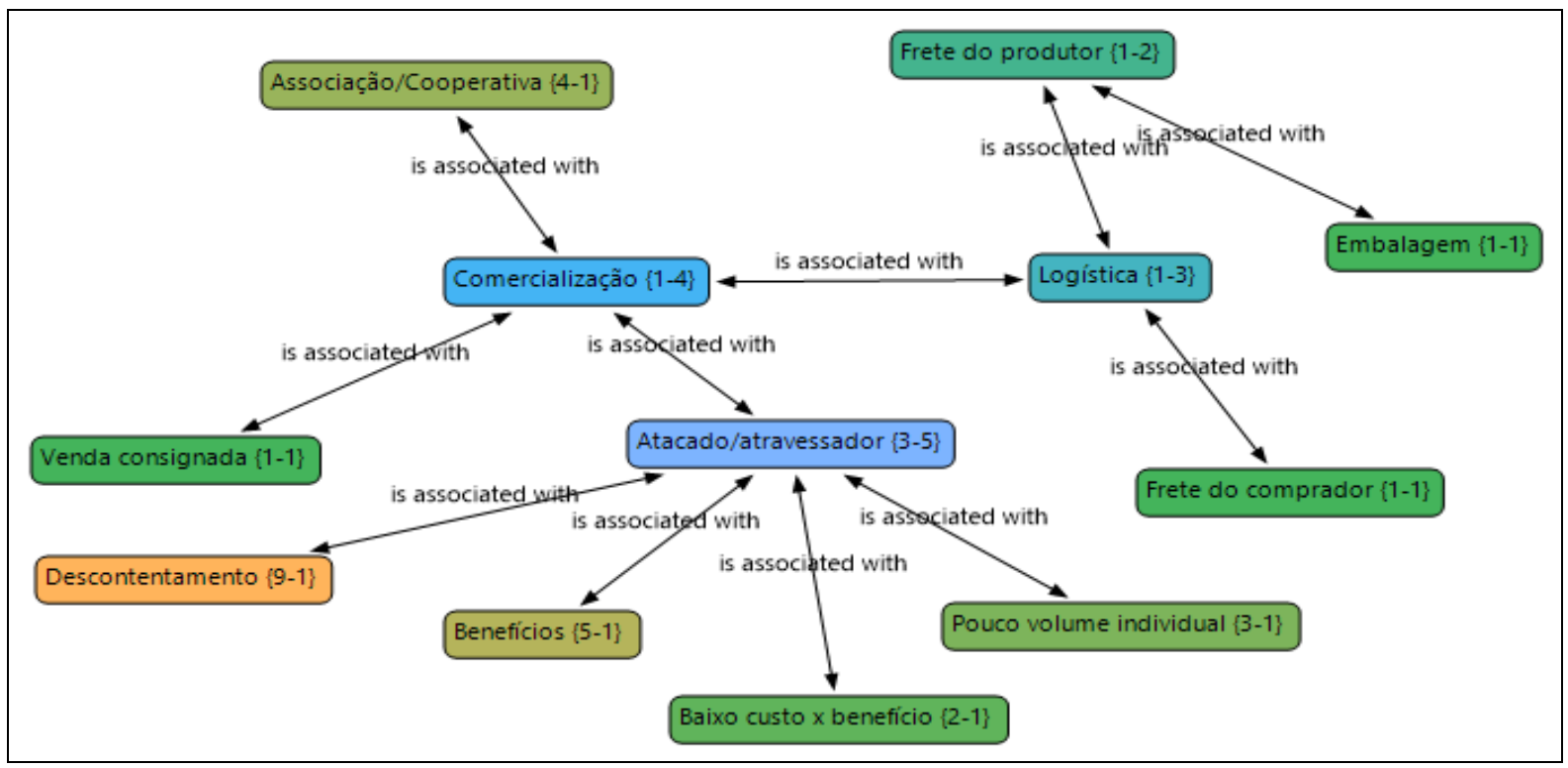

Figura 27: Rede da Comercialização da região Norte do Paraná

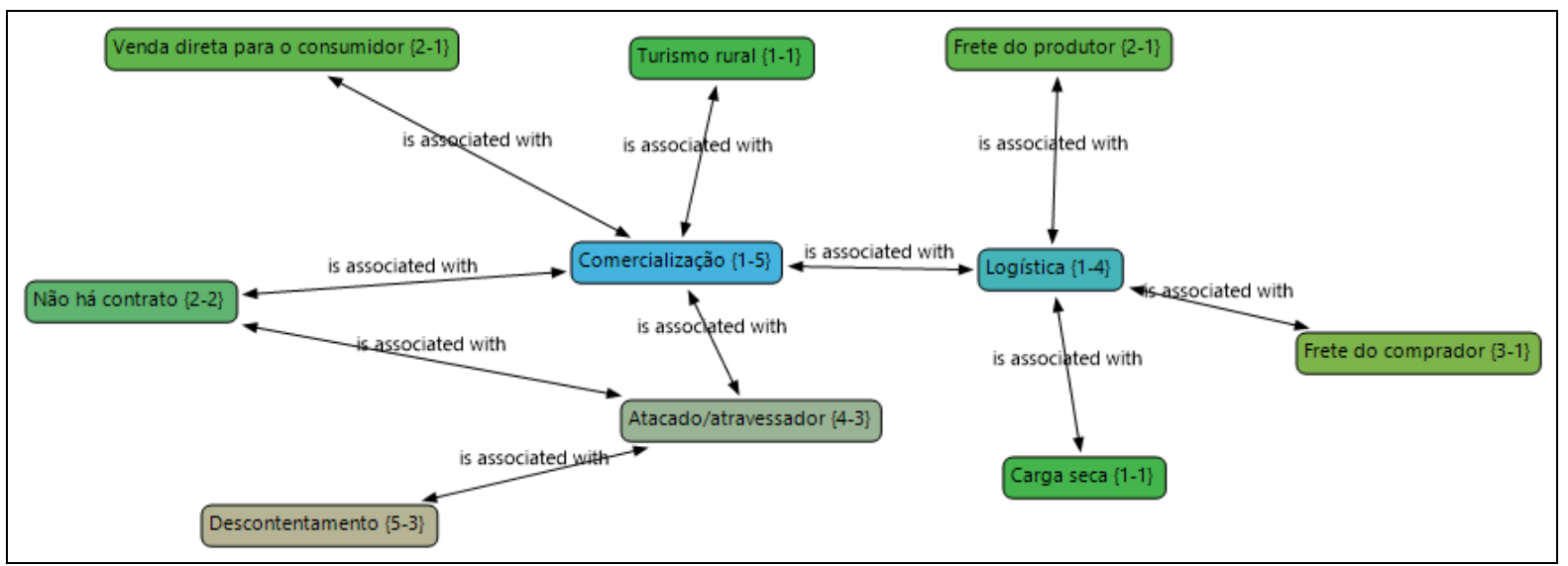

Figura 28: Rede da Comercialização da região de Campinas

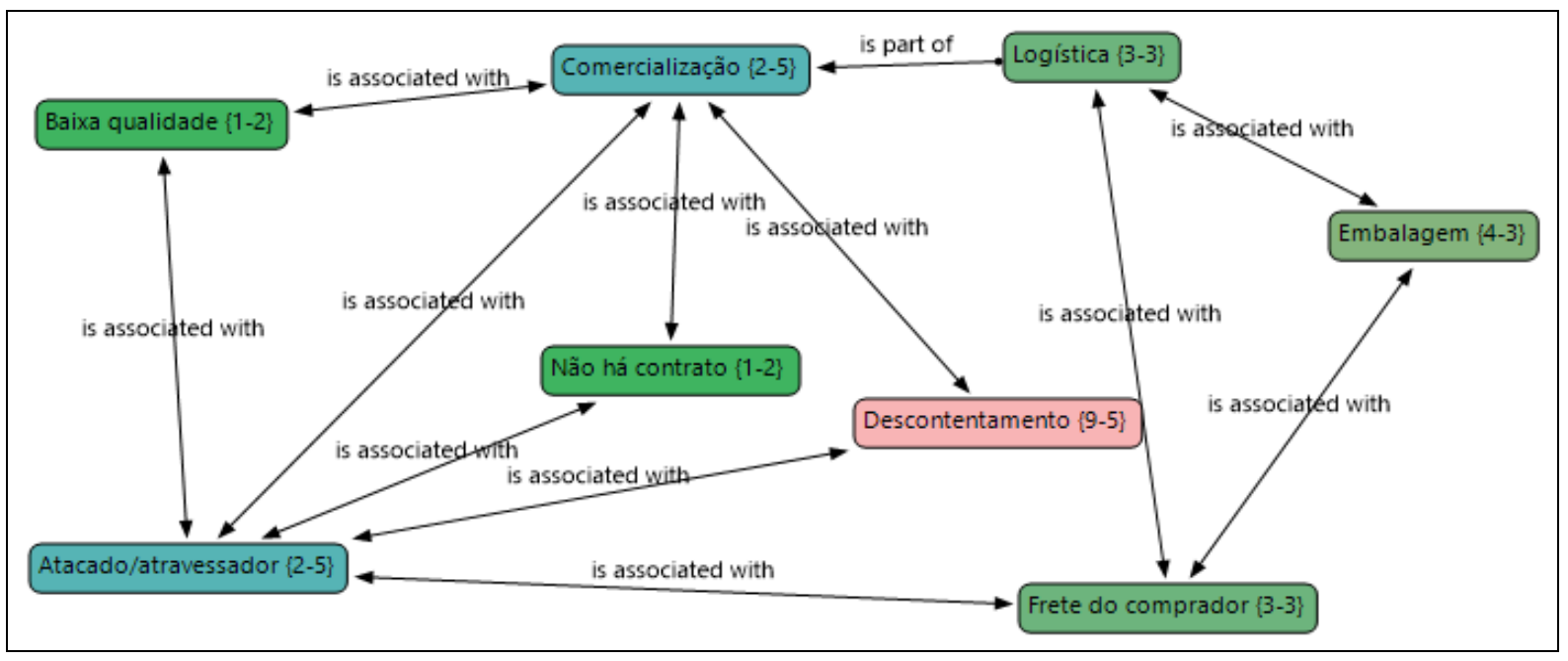

Figura 29: Rede da Comercialização da regional São José do Rio Preto (SP) 


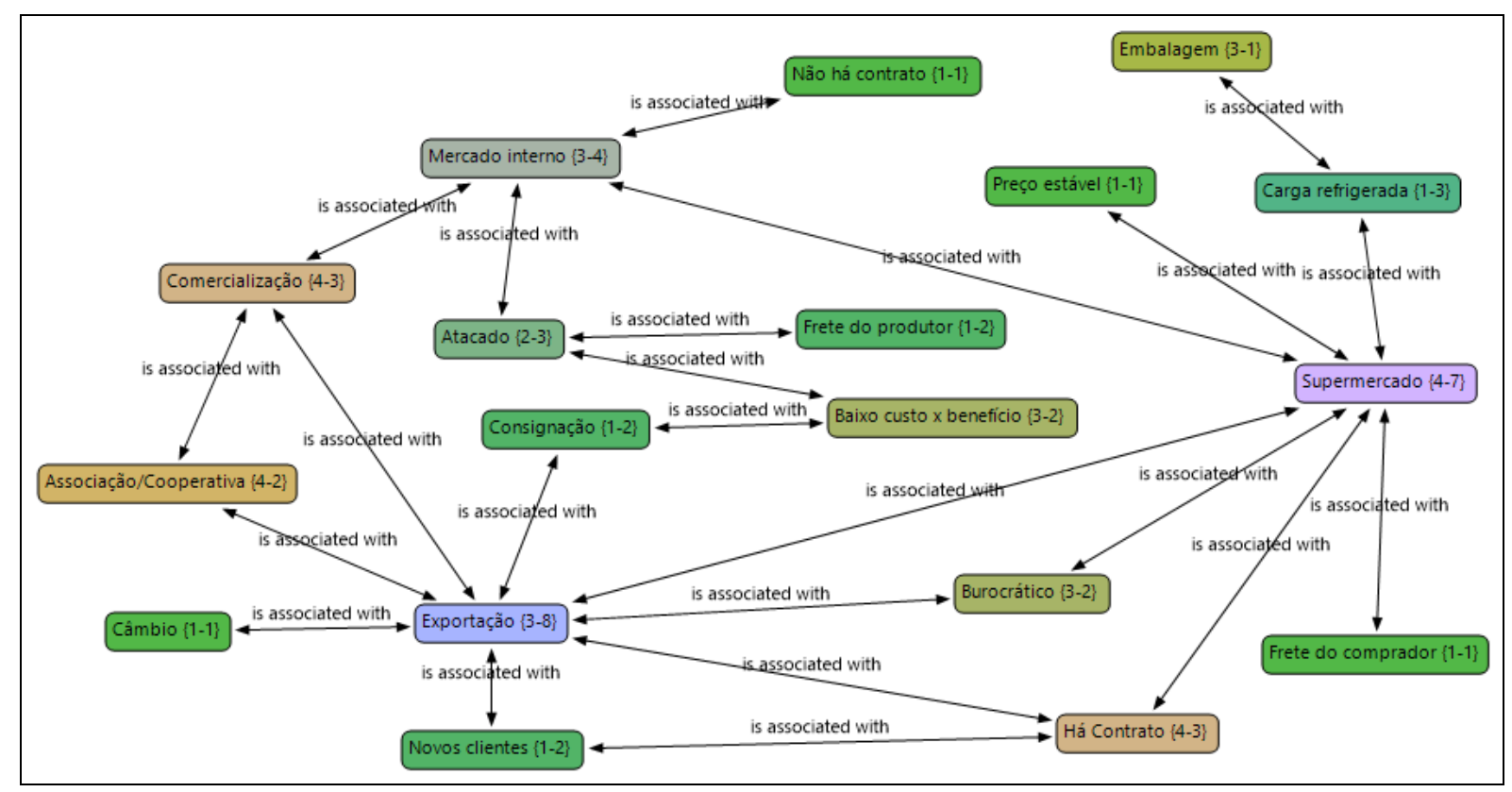

Figura 30: Rede da Comercialização da região do Vale do São Francisco

Na comparação geral, fica evidente que o Vale do São Francisco é mais competitivo que as outras regiões visto que teve os melhores parâmetros, tanto para o ambiente institucional quanto para tecnologia e comercialização. Na soma das análises da entrevista foram elencados 11 pontos $(+,-$ ou -/+). O Vale do São Francisco teve a maior somatória de pontos positivos (8), seguido por São José do Rio Preto, com 2 pontos positivos. As demais regiões tiveram apenas 1 ponto positivo em cada (Tabela 12). Já a região de Campinas foi a que mais registrou pontos negativos (10), seguida, também, por São José do Rio Preto, com 8 pontos negativos. Na comparação geral das entrevistas, assim, a região de Campinas também apresentou os piores parâmetros de competitividade.

Tabela 12: Comparação geral da competitividade

\begin{tabular}{lccc}
\hline \multicolumn{4}{c}{ Soma geral da competitividade } \\
\hline & + & - & $-/+$ \\
\cline { 2 - 4 } Macro Metropolitana Paulis ta & 1 & 7 & 3 \\
Norte do Paraná & 1 & 6 & 4 \\
Região de Campinas & 1 & 10 & 0 \\
Região de São José do Rio Pre to & 2 & 8 & 1 \\
Vale do São Francisco & 8 & 3 & 0 \\
\hline
\end{tabular}

Para a região Macro Metropolitana Paulista, o que tem auxiliado o produtor a ter ganhos positivos são os recursos em termos de tecnologia. O ambiente institucional para esta região é 
fraco, e não auxilia o produtor da forma que ele necessita. E na comercialização, com a falta de contratos e coordenação da produção com a venda, o produtor ainda fíca muito "na mão" dos compradores. No Norte do Paraná, nem mesmo o cooperativismo, que é muito presente nos estado do Sul do Brasil para a agricultura, impulsionou a competitividade do produtor de uva. Nesta região, o clima tem dificultado a produção da uva nos últimos anos, sendo um fator que o produtor não é capaz de modificar. O que tem sido feito são investimentos para que este tipo de problema seja amenizado. Sobre a comercialização, ainda, o produtor deixa a desejar sobre a qualidade da uva, colhendo a fruta antes do período ideal, o que acaba por pressionar os valores obtidos com a venda, diminuindo a competitividade.

A região de Campinas, por sua vez, tem ambiente institucional um pouco mais favorável frente às outras regiões. A maioria das prefeituras locais incentiva o cultivo de frutas, tendo em vista que a fruticultura atrai o turismo para a região (circuito paulista das frutas). Outro ponto que tem favorecido a competitividade em relação aos custos de produção é o investimento na troca de condução da parreira para o sistema em Y - que tem melhor produtividade que a espaldeira (modelo mais tradicional desta região), facilita a mecanização e a mão de obra e garante frutas de melhor qualidade. Em São José do Rio Preto, o ambiente institucional não é mais competitivo frente a de outras regiões. Por outro lado, em questão de tecnologia, a irrigação garante boa produtividade. Além disso, esta região tem um grande diferencial: oferta a fruta em período de baixa concorrência, o que estimula o incremento dos preços ao produtor, garantindo melhor rentabilidade. Assim, mesmo não tendo contratos de longo prazo e a fruta sendo vendida para atravessadores, os produtores da região tem tido boa competitividade de mercado.

Por fim, no Nordeste, em relação à competitividade geral desta região, pode-se notar maior participação de todas as três áreas analisadas. As associações/cooperativas são mais atuantes, principalmente para garantir a manutenção de pequenos e médios produtores neste mercado. Da parte tecnológica e de comercialização, é a região mais avançada - há investimentos em recursos físicos. 


\subsubsection{Análise dos preços ao produtor de uva}

Nas entrevistas foi captado, então, como está o ambiente institucional de cada região produtora assim como os fatores tecnológicos e de comercialização de cada uma. Porém, não houve comparação de um importante parâmetro de comercialização, o preço. Isso porque o preço está associado, de certa maneira, com a produtividade e a qualidade. Segundo Kupfer (1992), a competitividade está intrinsicamente relacionada ao fato de se produzir mais com menos insumos, ou seja, maior rendimento. No caso da uva de mesa, isso se traduziria em maior produtividade - toneladas/hectare. Com a maior produtividade, os custos de produção (por hectare) são diluídos, e o produtor conseguiria vender a fruta a preços mais competitivos no mercado em períodos de elevada concorrência. Por outro lado, se o produtor consegue vender a fruta a preços mais altos no mercado por conta da baixa pressão de concorrência, a rentabilidade é maior com os custos diluídos. Além disso, para produtos de alto valor agregado, como as uvas, a qualidade também é um fator determinante para o preço - a queda no preço em período de baixa concorrência pode ser decorrente de problemas de qualidade dos produtos, por exemplo. Assim, os principais fatores que impactam na concorrência seriam preço, qualidade, diferenciação de produto, dentre outros, de acordo com Kupfer (1992).

O preço, para Farina (1999) também é um fator da competição entre concorrentes de um determinado segmento. Segundo a autora, o ambiente competitivo, além de ser constituído pela estrutura de mercado (concentração, economia de escala, diferenciação, por exemplo), também é formado pelos padrões de concorrência. Neste último, a concorrência de preço pode ser citada, bem como a qualidade.

Para melhor comparação, os dados foram analisados por variedade de uva. Primeiramente se analisou a uva itália nas regiões que a produzem. Posteriormente, foi analisada a uva niagara, para o mesmo parâmetro nas regiões que produzem essa variedade.

\subsubsection{Uva itália}

A uva itália é produzida nas regiões de Macro Metropolitana Paulista, Norte do Paraná, São José do Rio Preto (SP) e Vale do São Francisco (BA/PE). Esta variedade 
representa as uvas finas de mesa com semente no País, já que nesta categoria é a uva que apresenta maior volume de produção, segundo informações obtidas no Cepea. Por isso, é também uma das uvas finas mais consumidas no Brasil (SATO, 2004).

Os preços da uva itália foram analisados entre 2001 e 2014. Os dados fornecidos pelo Cepea foram médias anuais por produtor. Na maioria dos anos pode-se notar que o maior preço médio nominal foi o da região de São José do Rio Preto, região que tem uma janela atrativa de mercado. A Tabela 13 mostra o preço médio nominal e os respectivos desviospadrões (DP) da uva itália em cada região produtora por ano analisado.

Tabela 13: Preços médios ( $\mathrm{R} \$ / \mathrm{kg})$ e desvios-padrões observados da uva itália em cada região entre 2001 e 2014

\begin{tabular}{ccccccccc}
\hline & \multicolumn{3}{c}{ M.M. Paulista } & \multicolumn{2}{c}{ Norte do Paraná } & \multicolumn{2}{c}{ S.J.Rio Preto } & \multicolumn{2}{c}{ V. São Francisco } \\
\hline Ano & Média & DP & Média & DP & Média & DP & Média & DP \\
\hline $\mathbf{2 0 0 1}$ & 0,91 & 0,21 & 0,95 & 0,06 & 1,27 & 0,08 & 0,95 & 0,04 \\
$\mathbf{2 0 0 2}$ & 1,02 & 0,13 & 1,15 & 0,14 & 1,27 & 0,16 & 1,09 & 0,23 \\
$\mathbf{2 0 0 3}$ & 1,24 & 0,17 & 1,23 & 0,21 & 1,34 & 0,05 & 1,16 & 0,09 \\
$\mathbf{2 0 0 4}$ & 1,11 & 0,12 & 1,05 & 0,20 & 1,35 & 0,05 & 1,58 & 0,19 \\
$\mathbf{2 0 0 5}$ & 1,11 & 0,26 & 1,38 & 0,46 & 1,88 & 0,25 & 1,71 & 0,43 \\
$\mathbf{2 0 0 6}$ & 1,77 & 0,17 & 1,45 & 0,22 & 1,92 & 0,19 & 1,60 & 0,34 \\
$\mathbf{2 0 0 7}$ & 1,77 & 0,30 & 1,80 & 0,27 & 1,64 & 0,21 & 1,75 & 0,32 \\
$\mathbf{2 0 0 8}$ & 1,49 & 0,28 & 1,69 & 0,18 & 2,06 & 0,17 & 1,92 & 0,13 \\
$\mathbf{2 0 0 9}$ & 2,14 & 0,37 & 2,02 & 0,25 & 2,51 & 0,14 & 2,16 & 0,33 \\
$\mathbf{2 0 1 0}$ & 2,34 & 0,25 & 2,07 & 0,16 & 3,20 & 0,16 & 2,14 & 0,22 \\
$\mathbf{2 0 1 1}$ & 2,25 & 0,26 & 2,25 & 0,26 & 2,24 & 0,19 & 2,2 & 0,24 \\
$\mathbf{2 0 1 2}$ & 2,13 & 0,21 & 1,78 & 0,36 & 2,38 & 0,19 & 2,10 & 0,20 \\
$\mathbf{2 0 1 3}$ & 2,26 & 0,26 & 2,38 & 0,55 & 3,10 & 0,43 & 2,68 & 0,42 \\
$\mathbf{2 0 1 4}$ & 3,58 & 0,29 & 2,82 & 0,51 & 3,28 & 0,38 & 2,87 & 0,26 \\
\hline
\end{tabular}

Fonte: dados de preços fornecidos pelo Cepea à autora e analisados estatisticamente

Dentre os dados fornecidos, nota-se em algumas regiões, grande variação de preços da uva itália entre os produtores de uma mesma região. Segundo produtores consultados, a variação de preços entre um produtor e outro ocorre por conta da qualidade da fruta e da negociação com o comprador. Além disso, a região de São José do Rio Preto tem os menores desvios padrões. Isso pode ser justificado pela safra única desta região. Em todas as outras regiões estudadas para a uva itália há duas safras ao ano (principal e a temporã nas regiões paulistas e no Paraná, ou $1^{\mathrm{a}}$ e $2^{\mathrm{a}}$ safra no Vale do São Francisco). Assim, a variação de preços é maior para estas regiões que produzem duas vezes ao ano. 
A Figura 31 mostra a variação do preço desta uva por meio de boxplots, no qual notase que em alguns anos houve variação maior do preço da uva.

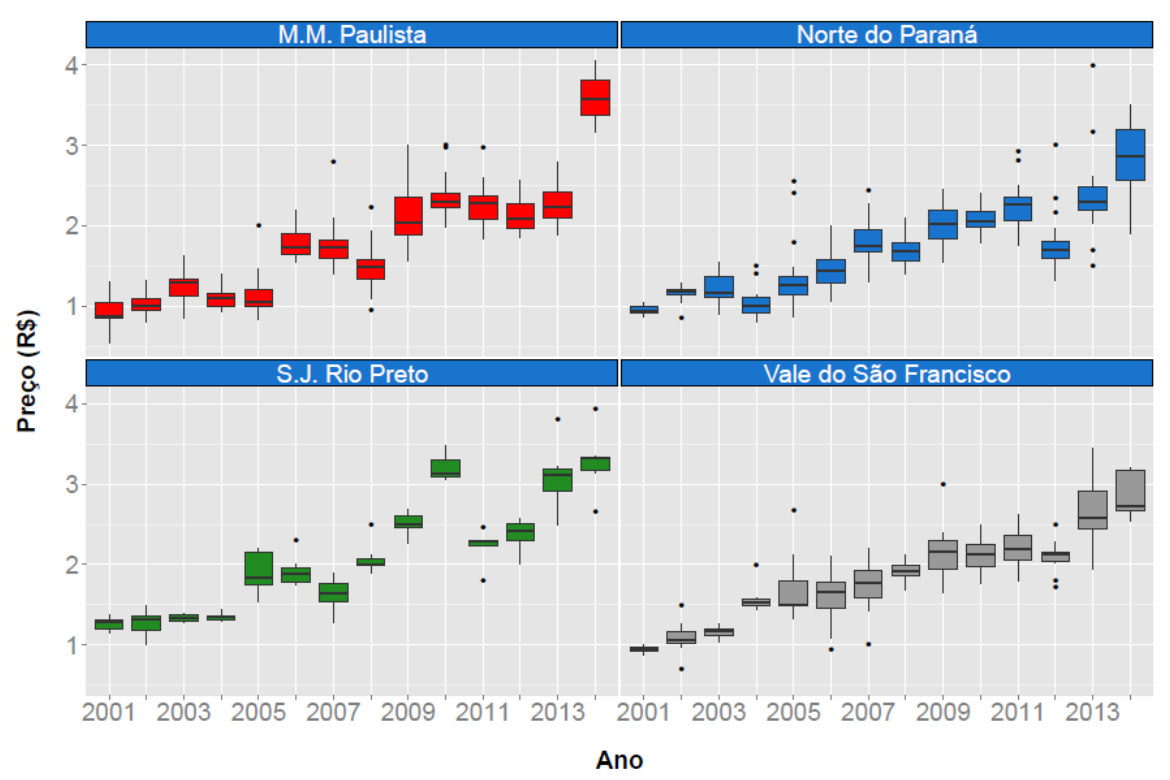

Figura 31: Variação do preço da uva itália ao longo dos anos

Para que as regiões fossem comparadas, o ajuste da curva da uva itália foi feito por um modelo com distribuição gama e função de ligação recíproca. A modelagem para o preço da uva itália pode ser visualizada no Apêndice E deste trabalho.

O modelo resultou em curvas com intervalos de confiança para cada região produtora de uva. As curvas ajustadas podem ser visualizadas na Figura 32.

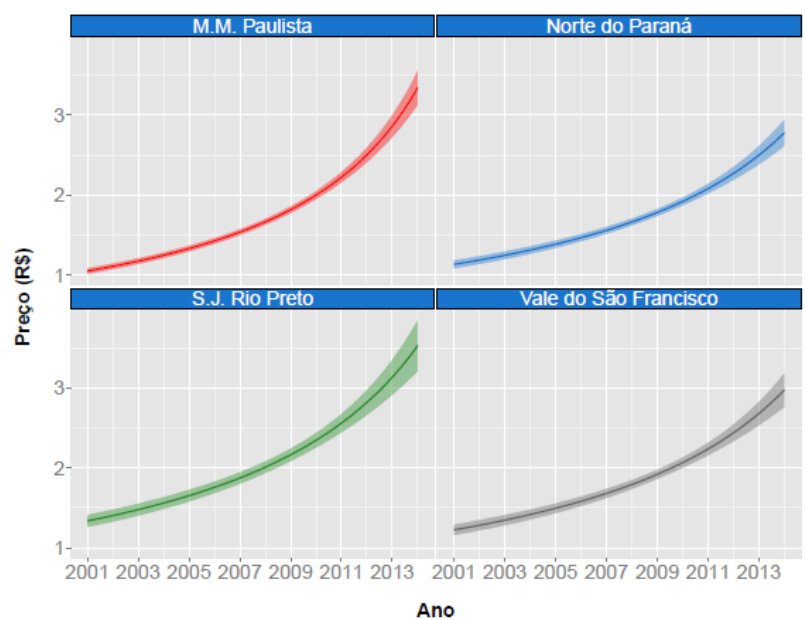

(a)

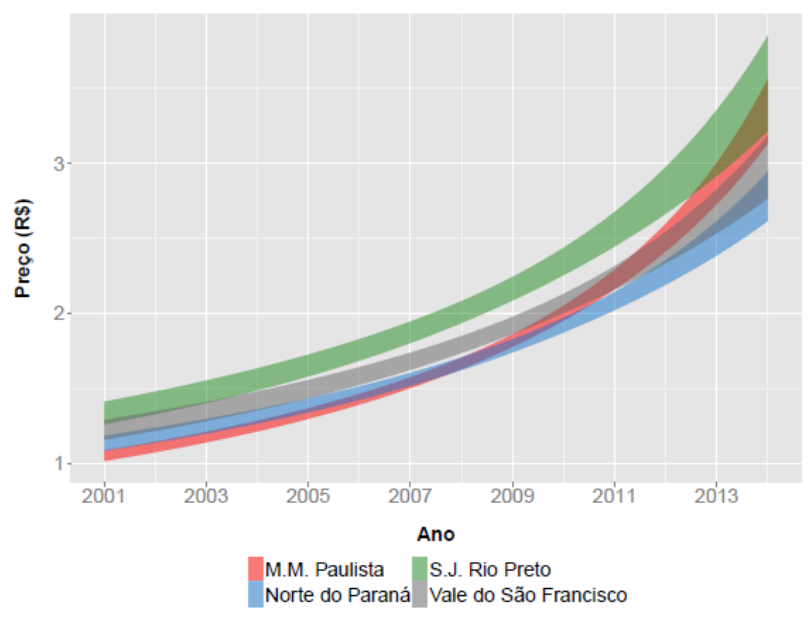

(b)

Figura 32: Intervalos de confiança das curvas de preço (em $\mathrm{R} \$ / \mathrm{kg}$ ) (a) e a comparação entre as regiões $(b)$ 
Com as curvas ajustadas, pode-se verificar que a da região Macro Metropolitana Paulista tem intersecção com as demais, bem como seu intervalo de confiança. Assim, estatisticamente, esta região não difere das outras três em relação aos preços da uva itália no mercado interno. Apesar disso, foi a região com maior crescimento dos preços médios no período analisado, conforme se pode visualizar na curva (Figura 32a).

Comparando-se as outras regiões, os preços do Norte do Paraná e de São José do Rio Preto diferem para todo o período analisado. Já as regiões de São José do Rio Preto e do Vale do São Francisco diferem apenas a partir de 2004, enquanto que o preço do Norte do Paraná e do Vale do São Francisco diferem entre 2005 e 2011. Assim, a região de São José do Rio Preto teve o maior preço da uva itália entre os anos de 2004 e 2011 - período em que houve diferença estatística das demais regiões.

\subsubsection{Uva niagara}

A uva niagara é a única representante da uva rústica de mesa (com semente) no Brasil. A variedade é produzida na região de Campinas (SP), São José do Rio Preto (SP), Macro Metropolitana Paulista e Norte do Paraná. Esta variedade tem ganhado mercado nos últimos anos no Brasil pela preferência do consumidor, segundo Capello (2014).

A uva rústica é de certa forma, concorrente da uva fina de mesa no mercado interno brasileiro, tendo em vista que, para o consumidor, a primeira é mais doce que a segunda. Além disso, o principal período de comercialização destas uvas é entre Natal e Ano Novo, o que aumenta a concorrência entre as variedades (ESPERANCINI; PEROSA; ROCHA, 2004).

O preços da uva niagara (rústica) foram analisados entre 2001 e 2014, assim como os da itália. Os dados fornecidos pelo Cepea foram, também, médias anuais por produtor. A Tabela 14 mostra o preço médio nominal e os respectivos desvios-padrões (DP) da uva niagara em cada região produtora no período analisado. O asterisco em 2005 indica que há somente uma observação disponível nesta regional e, portanto, não há desvio-padrão. Além disso, houve ausência de dados no ano de 2004 para a região de Campinas. 
Tabela 14: Preços médios $(\mathrm{R} \$ / \mathrm{kg})$ e desvios-padrões observados da uva niagara em cada região entre 2001 e 2014

\begin{tabular}{|c|c|c|c|c|c|c|c|c|}
\hline \multirow[b]{2}{*}{ Ano } & \multicolumn{2}{|c|}{ M.M. Paulista } & \multicolumn{2}{|c|}{ Norte do Paraná } & \multicolumn{2}{|c|}{ Região Campinas } & \multicolumn{2}{|c|}{ S.J.Rio Preto } \\
\hline & Média & DP & Média & DP & Média & DP & Média & DP \\
\hline 2001 & 0,98 & 0,39 & 0,92 & 0,11 & 0,70 & 0,07 & 1,90 & 0,36 \\
\hline 2002 & 1,12 & 0,18 & 1,17 & 0,17 & 0,92 & 0,40 & 1,65 & 0,26 \\
\hline 2003 & 1,24 & 0,29 & 1,16 & 0,23 & 1,55 & 0,01 & 1,85 & 0,14 \\
\hline 2004 & 1,34 & 0,43 & 1,07 & 0,30 & & & 2,03 & 0,09 \\
\hline 2005 & 1,66 & 0,21 & 1,60 & 0,31 & 1,18 & $*$ & 2,81 & 0,12 \\
\hline 2006 & 1,54 & 0,24 & 1,57 & 0,38 & 1,71 & 0,33 & 2,88 & 0,14 \\
\hline 2007 & 1,57 & 0,23 & 1,80 & 0,36 & 1,73 & 0,21 & 2,69 & 0,25 \\
\hline 2008 & 1,66 & 0,38 & 2,00 & 0,67 & 1,96 & 0,46 & 2,78 & 0,09 \\
\hline 2009 & 1,90 & 0,33 & 2,08 & 0,99 & 2,18 & 0,23 & 3,04 & 0,31 \\
\hline 2010 & 1,79 & 0,43 & 1,80 & 0,27 & 2,13 & 0,38 & 3,31 & 0,21 \\
\hline 2011 & 2,07 & 0,36 & 2,06 & 0,03 & 2,60 & 0,39 & 2,92 & 0,28 \\
\hline 2012 & 2,17 & 0,27 & 2,12 & 0,14 & 2,68 & 0,30 & 3,25 & 0,27 \\
\hline 2013 & 2,32 & 0,51 & 2,40 & 0,00 & 3,28 & 0,48 & 3,77 & 0,60 \\
\hline 2014 & 2,52 & 0,21 & 2,58 & 0,00 & 3,11 & 0,33 & 3,67 & 0,31 \\
\hline
\end{tabular}

Fonte: dados de preços fornecidos pelo Cepea à autora e analisados estatisticamente

Assim como para a uva itália, os preços médios da niagara foram maiores em quase todos os anos na região de São José do Rio Preto. Além disso, nota-se maiores desviospadrões para esta variedade. A Figura 33 mostra a variação do preço da uva rústica por meio de boxplots, para cada região produtora da variedade.

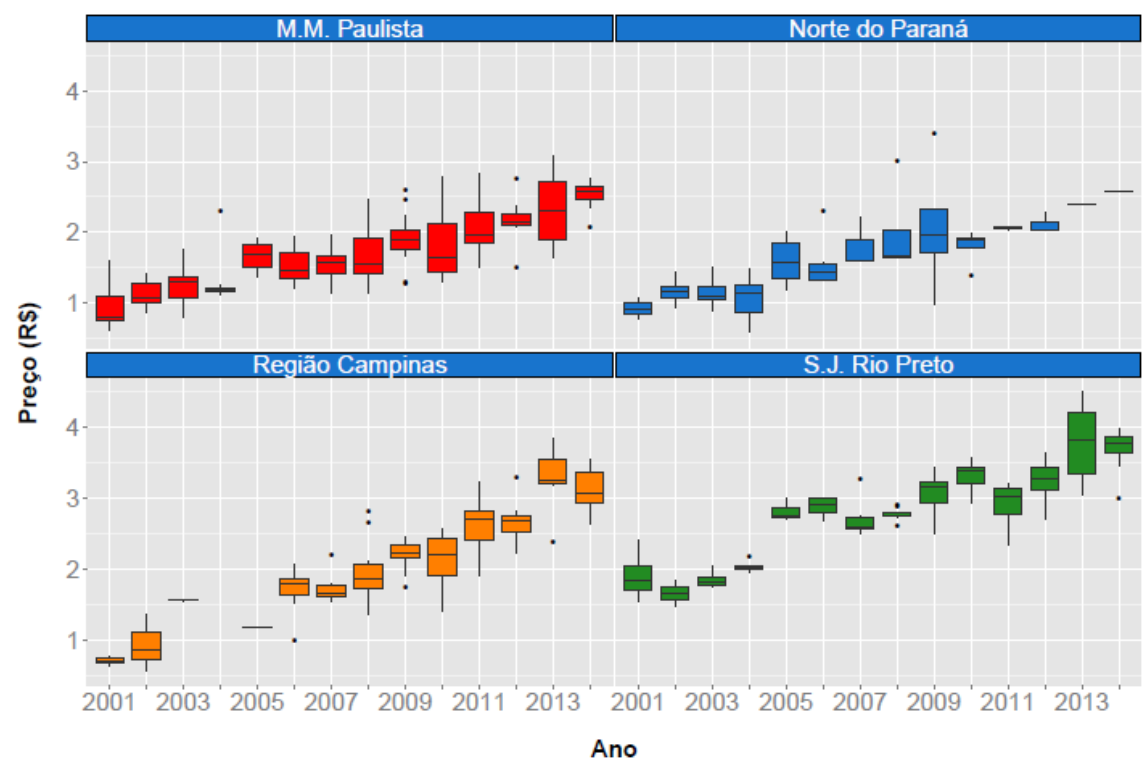

Figura 33: Variação do preço da uva niagara ao longo dos anos 
Para a avaliação e comparação do preço da uva niagara entre as regiões, foi ajustado um modelo que separa São José do Rio Preto das outras regionais, tendo em vista que a curva desta regional tem comportamento bastante diferente das demais, conforme a Figura 34. Assim, o modelo com resposta gama e ligação recíproca foi realizado fazendo essa separação e obtendo-se, desta forma, dois grupos (ou duas curvas). A modelagem pode ser observada no Apêndice F.

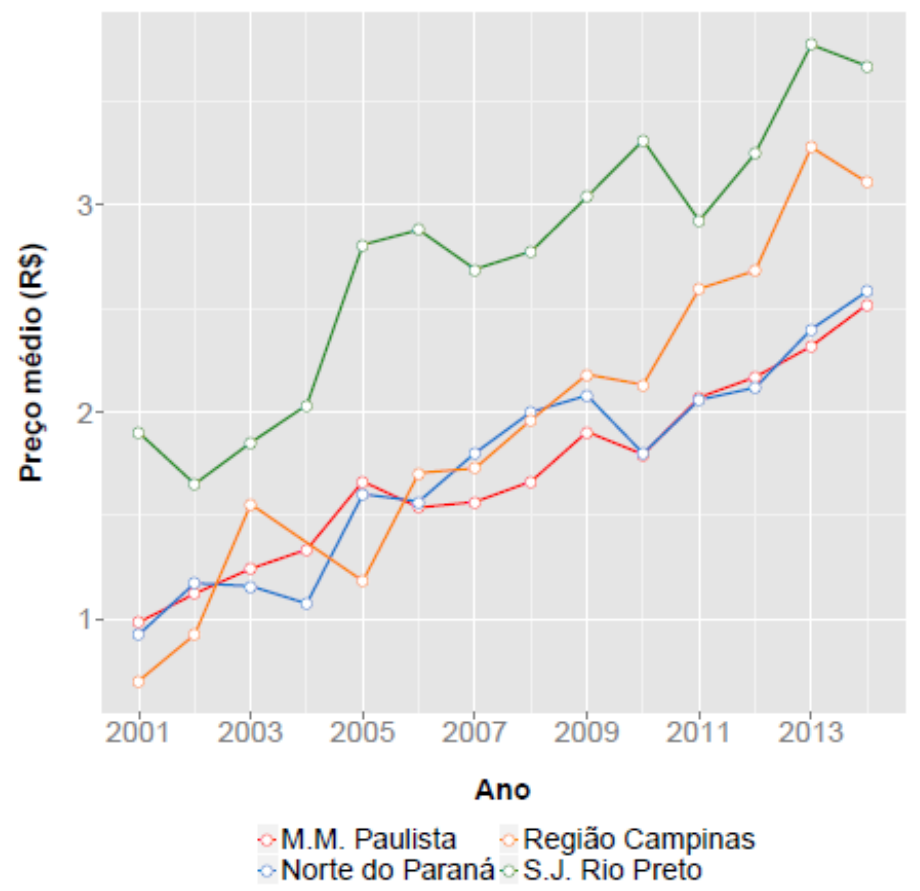

Figura 34: Curvas dos preços médios $(\mathrm{R} \$ / \mathrm{kg})$ da uva niagara em cada região entre $2001 \mathrm{e}$ 2014

Assim, a regional de São José do Rio Preto diferiu das demais, tendo o maior preço para a uva rústica no período analisado. As outras três regiões, assim, não se diferem estatisticamente entre si, mas pode ser verificado na Figura 34 que o maior crescimento dos preços nominais ocorreu para a uva niagara de Campinas (SP). 


\subsubsection{Considerações sobre a competitividade regional da viticultura}

As regiões produtoras de uva de mesa de São Paulo e Paraná se destacam pela atuação da agricultura familiar. Assim, muitas vezes, o produtor não cultiva apenas uva, mas também outros produtos, para garantir o sustento da família durante o ano todo, tendo em vista que a uva, mesmo sendo uma cultura perene, é sazonal - ou seja, gera renda apenas em alguns meses do ano. Esse produtor familiar, no geral, tem pouco capital para grandes investimentos. E, ainda, a estrutura do parreiral é custosa - a estrutura fixa de um parreiral é um insumo de alta especificidade, dificultando a saída da atividade.

Por outro lado, a região nordestina analisada neste trabalho (Vale do São Francisco) tem uma agricultura voltada para a produção de frutas com destino à exportação, podendo ser considerada de uma gestão e comercialização mais profissional. Além disso, essa região consegue colher uva, além de outras frutas, durante o ano inteiro, garantindo melhores fontes de renda ao fruticultor e diluindo os custos de produção.

Além deste cenário, a partir das análises dos resultados nos itens anteriores, pode-se verificar se as hipóteses formuladas no item 2.5. se confirmam, ou não.

A primeira hipótese formulada para a competitividade das regiões brasileiras foi:

A região produtora de uva de mesa do Vale do São Francisco (BA/PE) é a mais competitiva no Brasil, tendo em vista os melhores padrões tecnológicos.

Realmente foi verificado que esta região detém os melhores padrões tecnológicos frente às outras regiões produtoras de uva de mesa do Brasil estudadas neste trabalho. $\mathrm{O}$ uso de tecnologia na fruticultura remete à melhor competitividade, segundo Fioravanço (2009). Já as regiões paulistas e a paranaense aqui estudadas, com a forte presença da agricultura familiar, têm investimentos mais limitados. Com exceção, de modo parcial, da regional de São José do Rio Preto, que tem irrigação.

Este cenário foi confirmado pelas entrevistas qualitativas, já que produtores do Vale do São Francisco são os que mais investem em tecnologia de campo e em novas variedades, buscando, inclusive, adotar padrões existentes na Europa, nos Estados Unidos e na África do Sul, o que não ocorre em nenhuma outra região produtora brasileira. Estas tecnologias podem ser elencadas como incrementais, pois são feitas em produtos e processos que já existem, e que geram mudanças significativas com o passar do tempo (DICKEN, 2010). 
Além disso, o Vale é a única região brasileira a ter uvas durante o ano todo com a qualidade exigida pelo mercado internacional, obtendo certificações e sendo a região exportadora do Brasil.

Por outro lado, na análise dos preços de uva itália e niagara, no geral, a região de São José do Rio Preto foi a que mais se destacou frente às outras regiões no período analisado. Uma explicação importante para este fato, que já tinha sido apontado por Barros e Boteon em 2002 e que também constatado nesta pesquisa, é que esta região se beneficia em ofertar a fruta em período de baixa disponibilidade nas outras regiões, o que garante boa remuneração.

Vale ressaltar, porém, que a rentabilidade unitária ao produtor do Vale do São Francisco é dependente, ainda, do desempenho dos preços de exportações. Sendo assim, devese analisar com cuidado os dados para o Vale do São Francisco, que podem limitar os resultados obtidos.

$\mathrm{Na}$ análise qualitativa (entrevistas), a comercialização de uvas ainda é um gargalo para muitos produtores. Viticultores do Paraná e São Paulo, desde 2002, segundo Barros e Boteon, já tinham dificuldades para negociar a uva, sendo que eles assumem mais riscos ao comercializar por conta do baixo volume de produção e limitado poder de barganha frente aos compradores. Este último item está de acordo com uma das cinco forças de Porter (2008), quando os compradores exercem poder de negociação.

Assim, concluiu-se a partir das entrevistas que, mesmo tendo bons preços, a região de São José do Rio Preto ainda tem que se aperfeiçoar nas relações comerciais, bem como todas as outras regiões produtoras de uva. E no Vale do São Francisco, fatores como condições climáticas, nível tecnológico, tamanho e gestão das propriedades e organização dos produtores, fazem com que esta seja a região mais competitiva brasileira, seja para o pequeno e médio produtor associado em cooperativas, seja para as grandes empresas localizadas na região.

A segunda hipótese testada foi:

A viticultura brasileira ganha/adapta tecnologia para substituir a falta de mão de obra.

De acordo com as entrevistas realizadas, produtores de todas as regiões estudadas "fazem qualquer coisa" para depender menos da mão de obra. Assim, essa hipótese foi confirmada. Durante as entrevistas, ainda, produtores de uva de mesa relataram que conseguir mão de obra para o trabalho rural está difícil, além de ser muito custosa. No geral, os trabalhadores buscam emprego nas cidades e não querem mais ficar no campo, embaixo de 
sol no caso das estruturas em espaldeiras, por exemplo. E o produtor, ainda, deve oferecer um salário competitivo frente a alguns empregos na cidade para conseguir mão de obra.

Além disso, ainda há o fato da sucessão familiar. Nem os filhos dos produtores querem trabalhar no campo com a uva, deixando a propriedade. Este cenário pode culminar em redução da produção nos próximos anos e/ou concentração da produção, tendo em vista que alguns produtores podem comprar ou arrendar as terras de outro.

Dessa forma, o fruticultor, de um modo geral, busca depender o mínimo possível de mão de obra contratada, tendo em vista que, com a intensidade no uso deste insumo, há elevada dificuldade em se conseguir escala de produção neste item, ou seja, quanto maior a área em produção, mais funcionários o produtor deve contratar e, consequentemente, o custo não reduz (FAVARET-FILHO; ORMOND; PAULA, 1998).

Nesta hipótese vale destacar, ainda, que o Vale do São Francisco é a região com mais mão de obra/hectare frente às outras. Por isso, há grande parcela de propriedades que utilizam mão de obra familiar na amostragem neste estudo, sobretudo nas regiões de São Paulo e no Paraná. Além disso, produtores de todas as regiões analisadas reclamam muito da falta de mão de obra especializada para o trabalho na fruticultura, como também foi constatado por outros autores, como Cavalcanti (1997), Barrientos e Barrientos (2002) e Vital et al. (2011). Além disso, a mão de obra preferida na viticultura é a feminina (Cavalcanti, 1997; Vital et al., 2011), sendo ainda mais difícil de conseguir para o trabalho no campo. Favaret-Filho, Ormond e Paula (1998) ainda relatam que a falta de especialização da mão de obra é advinda da falta de especialização do produtor também, sendo uma deficiência no campo.

A terceira hipótese relacionada, ainda, com a produção brasileira, foi:

No Brasil, os recursos (mão de obra, tecnologias de produção/maquinário, etc.) são fatores mais positivos para a competitividade do mercado doméstico do que as instituições nacionais (regras, políticas, legislações, etc.).

Somando as entrevistas realizadas neste trabalho com a análise do ambiente institucional brasileiro, confirma-se a hipótese, destacando-se, ainda, a região do Vale do São Francisco, que detém os melhores recursos. Um exemplo da literatura é que, na década de 90 , a produção no Vale do São Francisco já tinha maior competitividade comparativamente a outras regiões produtoras de uva de mesa por conta, sobretudo, dos recursos (tecnologia, mão de obra etc.) disponíveis (DA-SILVA, et al., 1999).

$\mathrm{O}$ ambiente institucional brasileiro é fraco e isso pode ser constatado principalmente nas questões de seguro rural. O crédito agrícola para o produtor brasileiro de uva de mesa ainda exerce, de certa forma, sua função, tendo em vista que muito respondentes da pesquisa 
qualitativa identificaram como sendo importante pata investimentos na cultura. Capello (2014) também identificou que produtores de uva de São Miguel Arcanjo, cidade que está na região Macro Metropolitana Paulista, utilizam o Pronaf para o custeio da produção. Ainda em relação ao crédito agrícola, para o setor de frutas e hortaliças é mais difícil encontrar outras formas de custeio que não seja o governamental. Por exemplo, Almeida e Zylbersztajn (2008), citam a evolução do mercado de contratos de crédito agrícola para financiamento privado da produção de soja como forma de depender menos dos recursos do governo. Esse tipo de contrato permite que produtores acessem recursos para financiar a produção, sendo que os compradores têm garantia de fornecimento, sendo uma cadeia com coordenação mais estruturada que a fruticultura. Nenhum produtor de uva entrevistado para este trabalho citou algum tipo de contrato ou relação semelhante a essa da soja.

Porém, o seguro rural é limitado para produtores de uva e frutas em geral. De acordo com Macedo, Pacheco e Santo (2013), o seguro rural oferece pouca proteção à fruticultura, sendo que para grãos e cana-de açúcar, por exemplo, há seguro contra geada, incêndio, queda de raio, tromba d'água, ventos fortes e frios, chuvas excessivas, seca, além do granizo. As seguradoras privadas brasileiras, de um modo feral, não se arriscam em propiciar ao viticultor outro tipo de seguro que não seja o contra granizo.

Ainda sobre o ambiente institucional, as associações e cooperativas exercem um papel mais influenciador de competitividade do que os outros dois parâmetros supracitados. De acordo com as entrevistas, as cooperativas de maior sucesso estão no Vale do São Francisco, onde, sem elas, os pequenos e médios produtores de uva não se sustentariam no setor. As cooperativas desta região nordestina, segundo Pires e Cavalcanti (2009), são competitivas e buscam a inovação e o profissionalismo na produção e comercialização de frutas, com foco, sobretudo, nas exportações. Até existem associações/cooperativas em outras regiões, mas estas não exercem forte influência para que a competitividade se sobressaia.

Por outro lado, são os recursos que mais influenciam positivamente a competitividade da viticultura brasileira. Foi captado nas entrevistas que a presença de alguns recursos em determinada região pode gerar vantagem competitiva. A irrigação, por exemplo, é uma tecnologia que está presente apenas no Vale do São Francisco e na região de São José do rio Preto, as quais foram detectadas como mais competitivas do Brasil, frente às outras estudadas. Em 2014/15, porém, essa disponibilidade de água está mais restrita no Vale do São Francisco, tendo em vista a crise hídrica que tem afetado várias regiões brasileiras. O volume de água do Rio São Francisco está mais baixo e, consequentemente, há menor vazão dos reservatórios que abastecem os sistemas de irrigação dos fruticultores da região. Em virtude disso, 
produtores de uva modernizaram ainda mais seus sistemas de irrigação e estão deixando podar parte dos parreirais, para menor necessidade hídrica.

Em relação ainda às tecnologias, que são recursos se analisarmos pela VBR, a região que mais as emprega é a do Vale do São Francisco, também. Nesta região estão os produtores mais tecnificados, o que garante competitividade para a exportação da fruta. Para esta, um recurso valioso para garantir boa competitividade é a proximidade com os portos. As outras regiões até estão a uma distância razoável de portos, mas não investem em tecnologias suficientes para garantir que a fruta chegue com qualidade em outros continentes.

Outro recurso é a oferta e uso de mão de obra/hectare, que no Vale é mais positivo que em outras regiões, o que possibilita melhor rendimento e manejo da cultura, mas que por outro lado, gera mais custos. A viticultura, de um modo geral, não tem ganho de escala com a mão de obra, ou seja, quanto maior a propriedade e área de produção com uva, maior a necessidade de mão de obra e o gasto com ela. Neste quesito, a região de Campinas tem a menor competitividade, já que a proporção de mão de obra/hectare é a mais baixa. Isso, também, impacta na produtividade.

Além dos recursos citados acima, vale destacar a proximidade com o mercado consumidor, que é um fator que tem possibilitado a permanência de alguns produtores na cultura, como no caso das regiões paulistas de Campinas e Macro Metropolitana Paulista, que estão localizadas próximas ao maior centro consumidor do País, a cidade de São Paulo. Porém, esta proximidade, apesar de positiva, faz com que as uvas sejam transportadas sem refrigeração, fator que deprecia a qualidade. No Vale, ocorre o inverso: a longa distância seria um empecilho, mas produtores e comerciantes investem em transporte refrigerado, permitindo melhor qualidade do produto final e garantindo, assim, melhores negócios.

Outro fator, que é externo ao produtor, mas que impacta também na competitividade é o clima - ele é um dos determinantes da produtividade e qualidade da fruta. Esta última, por sua vez, quando satisfatória, determina uma melhor remuneração do produtor. O clima, para a uva, impacta também no calendário de colheita, e com isso, essa região consegue colher em período de baixa oferta de uva das outras regiões, o que garante a vantagem competitiva desta região. Produtores do Paraná, por exemplo, relataram que gostariam de colher no período que São José do Rio Preto produz, quando os preços são mais elevados, mas por questões climáticas, isso não é possível.

No Paraná, ainda, o clima tem sido um empecilho para a produção - o granizo e as geadas têm ocorrido em períodos pouco propícios (meses de podas e brotação), e danificam a produção, causando perdas aos agricultores da região. Esses problemas climáticos também 
impactam na uva de Campinas e da regional Macro Metropolitana Paulista, mas com menor intensidade que no Paraná. O clima também é o responsável pelos ajustes na produção no Vale do São Francisco por conta da crise hídrica.

Assim, conclui-se que, para a viticultura, o ambiente institucional gera menos incentivos para a competitividade deste setor frente aos recursos.

\subsection{Competitividade internacional da viticultura}

\subsubsection{Brasil é pouco competitivo no Ambiente Institucional Internacional}

A competitividade internacional está relacionada com a habilidade de produzir e comercializar de forma mais eficiente que os concorrentes (GASQUES; CONCEIÇÃO, 2002). Para avaliar a competitividade internacional no presente estudo, então, primeiramente foi realizada a análise do ambiente institucional (neste item) e, posteriormente, a evolução da produção e comercialização da uva de mesa, em termos numéricos, para os países-foco (item 4.2.2.): Brasil, Chile e Itália.

Em relação ao ambiente institucional, que afeta, sobretudo, a comercialização da uva no mercado internacional, tem grande importância as questões sobre barreiras tarifárias e não tarifárias do comércio exterior. As primeiras são as tarifas e taxas de importação dos produtos, sejam eles de qualquer natureza. Já as não tarifárias incluem licenciamento de importação, procedimentos alfandegários, valoração aduaneira arbitrária, medidas antidumping e compensatórias, subsídios, medidas de salvaguarda, entre outras (MDIC, 2015). As barreiras não tarifárias são bem mais complexas que as barreiras tarifárias.

Primeiramente, quando um país faz parte de um acordo comercial, as medidas tarifárias e comerciais são mais brandas frente a países que não participam de um mesmo bloco ou grupo econômico. O Brasil tem 19 acordos comerciais em vigência, atingindo apenas 16 países, e a maior parte deles é por conta do Mercosul (Mercado Comum do Sul), que engloba, além do Brasil, a Argentina, Uruguai, Paraguai (desde 1991) e Venezuela (desde 2012) - a Bolívia deve ser incorporada ainda em 2015. O Mercosul prevê a livre circulação de bens e serviços entre os países membros, estabelece uma Tarifa Externa Comum (TEC), adota 
uma política comercial comum e harmoniza as legislações nas áreas pertinentes ao comércio internacional. A Tarifa Externa Comum (TEC) na comercialização para uva, é de 10\%, semelhante a de outras, e aplicada a todos os países, exceto se houver algum acordo vigente. Dentre os dois países de comparação deste estudo, o Brasil tem acordo apenas com o Chile ACE (Acordo de Complementação Econômica) 35, entre Mercosul e Chile, o que reduz as tarifas de importação entre esses países (MDIC, 2015).

Já o Chile tem 22 acordos vigentes com 60 países, e a maioria deles de livre comércio (16), inclusive com os Estados Unidos, Japão e China, com os quais o Brasil não tem nenhum tipo de acordo vigente até 2015. O Chile tem, ainda, Acordo Comercial com a União Europeia, o que já garante relações com 28 países (Aduana, 2015).

A Itália, por sua vez, se beneficia do fato de ser um membro da União Europeia (UE), o que facilita e garante livre comércio com os outros 27 países membros. Além destes, a Itália tem acordos com mais 50 países por conta da UE, sendo 32 acordos comerciais vigentes deste bloco econômico. A UE ainda tem vários acordos em pauta para firmar e se consolidar, inclusive com o Brasil (European Comission, 2015).

Em relação às tarifas de comercialização entre esses três países, o Chile e a Itália tem relação mais facilitada - tarifa preferencial de $0 \%$ entre os dois países (Tabela 15). Já o Brasil, tem baixa competitividade na comercialização com esses países - enquanto a uva chilena entra no Brasil com tarifa de $0 \%$, a fruta brasileira entra no Chile com tarifa de 5,28\%; e a uva brasileira chega à Itália e União Europeia pagando 11,5\% de tarifa enquanto a uva italiana chega ao Brasil com 10\% de tarifa de importação (ASOEX, 2015; MDIC, 2015; European Comission, 2015).

Tabela 15: Acordos Comerciais de Brasil, Chile e Itália e tarifas para a comercialização de uva de mesa entre esses países

\begin{tabular}{lccc}
\hline & Brasil & Chile & Itália \\
\hline Número de Acordos Comerciais vigentes & 19 & 22 & 32 \\
Número de países atingidos com os Acordos & 16 & 60 & 77 \\
Tarifa para exportação de uva ao Brasil & - & $0 \%$ & $10 \%$ \\
Tarifa para exportação de uva ao Chile & $5,28 \%$ & - & $0 \%$ \\
Tarifa para exportação de uva à UE & $11,50 \%$ & $0 \%$ & $0 \%$ \\
\hline
\end{tabular}

Fonte: Elaborado pela autora a partir de MDIC; Aduana; ASOEX, European Comission, 2015

Assim, no quesito das barreiras tarifárias, o Brasil sai perdendo em termos de competitividade internacional frente a Chile e Itália. Dentre esses dois países, o Chile tem 
melhores tarifas para comercializar com o Brasil, porém, a Itália tem mais acordos comerciais vigentes, o que garante melhor competitividade.

Em relação às barreiras não tarifárias, as mais importantes são as normas fitossanitárias entre Brasil, Chile e Itália para a comercialização da uva de mesa. De acordo com o Ministério da Agricultura, o Brasil pode importar uva de mesa in natura do Chile e da Itália, e mudas e estacas para propagação vegetativa (material genético) apenas da Itália, desde que sigam alguns pré-requisitos em termos de sanidade das frutas e materiais.

Os requisitos do Ministério da Agricultura para a fruta chilena entrar no Brasil são: inspeção fitossanitária no ponto de ingresso (na fronteira ou porto); Certificado Fitossanitário ou Certificado Fitossanitário de Reexportação correspondente, que garanta que a uva foi tratada com fumigação para o controle do ácaro Brevipalpus chilensis; e, a uva não deve apresentar risco quarentenário em relação ao mesmo ácaro. Para a entrada de uva in natura italiana e de muda e estaca para material genético, é necessária apenas a inspeção fitossanitária no ponto de ingresso (porto), acompanhada Certificado Fitossanitário ou Certificado Fitossanitário de Reexportação correspondente (MAPA, 2015). Ou seja, a entrada de fruta italiana é mais facilitada frente à chilena em termos de requisitos fitossanitários.

No caso do Chile, existem Convênios Fitossanitários para a comercialização de frutas, realizados pelo esforço conjunto do Serviço Agrícola e Pecuário (SAG) do governo chileno e associações do setor, mas que são financiados, sobretudo, pela Associação dos Exportadores de Frutas do Chile (Asoex), entidade que promove a fruta chilena no exterior. Esses convênios estão assinados junto aos Estados Unidos, México, Japão, Coreia do Sul, China, Taiwan e Canadá, para que seja facilitada a entrada de uva de mesa chilena nesses países, permitindo acesso imediato. Para que isso ocorra, autoridades fitossanitárias internacionais inspecionam os pomares do Chile (ASOEX, 2015). Não existem acordos fitossanitários do Chile com Brasil e Itália. Além disso, na busca por requisitos de importação de uva de mesa fresca no SAG do Chile, foi encontrado apenas para a Índia e para os Estados Unidos. Isso significa que somente esses dois países tem autorização para enviar o produto. Caso algum outro país esteja interessado em enviar uva de mesa fresca para o Chile, deve solicitar ao SAG através de um formulário.

Para a Itália e União Europeia como um todo, existem algumas medidas sanitárias e fitossanitárias que são impostas aos países que possuem acordos com a UE. No sistema da Comissão Europeia, foi verificado que o Chile necessita de certificados para exportar uva de mesa para a Itália. São eles: controle de resíduos e contaminantes químicos na uva fresca; Certificado Fitossanitário ou Certificado Fitossanitário de Reexportação correspondente; 
Registro e aviso prévio das importações; programa de rastreabilidade e rotulagem adequada. No mesmo sistema da Comissão Europeia não foram encontrados dados e medidas para o Brasil, provavelmente pela falta de Acordos Comerciais entre Brasil e União Europeia.

Assim, de um modo geral, no que diz respeito ao Ambiente Institucional, o Brasil ainda é pouco competitivo, sobretudo frente ao Chile, que detém uma entidade (associação) que promove fortemente as frutas desse país no exterior.

\subsubsection{Avaliação da produção e comercialização internacional de uva do Brasil, Chile e Itália}

A competitividade internacional é relacionada, sobretudo, ao desempenho na produção e comercialização dos produtos no mercado global. A seguir, estão detalhados os dados de produção, produtividade, exportação, importação, preços e consumo aparente da uva de mesa para Brasil, Itália e Chile. Para todos os dados (com exceção do preço), foi verificado o crescimento em índice 100 ao longo dos anos analisados. O índice relativo 100 indica o quanto um valor é maior ou menor em um período de tempo em relação ao período base (ano, mês, dia etc.). $\mathrm{O}$ índice relativo 100 é normalmente apresentado na forma de porcentagem (\%) (FARIAS; LAURENCEL, 2005).

Em relação à produção de uva de mesa, o volume médio do Brasil entre 2000 e 2013 foi bem menor quando comparado ao do Chile e da Itália, conforme pode ser verificado na Tabela 16. O Brasil, por outro lado, teve a melhor taxa de crescimento frente aos outros dois países, tendo alta de $22 \%$ no volume de produção entre 2000 e 2013 e foi seguido de perto pelo Chile, com alta de $17 \%$ na produção no mesmo período.

A Itália e o Chile registraram volumes de produção bem próximos - pouco mais de um milhão de toneladas. Mesmo tendo a maior média de produção de uva de mesa entre os três países, a Itália apresentou recuo de $27 \%$ na evolução da produção ao longo dos anos analisados, sobretudo a partir de 2007 (Figura 35a).

Vale lembrar que os três países produzem também uvas para industrialização (suco, vinho e espumantes), mas que não estão contabilizadas nesta estatística. 
Tabela 16: Evolução da produção e da produtividade da uva de mesa do Brasil, Itália e Chile

\begin{tabular}{|c|c|c|c|c|c|c|}
\hline & \multicolumn{3}{|c|}{ Produção - em mil toneladas } & \multicolumn{3}{|c|}{$\begin{array}{l}\text { Produtividade média - em } \\
\text { toneladas/hectare }\end{array}$} \\
\hline & Brasil & Itália & Chile & Brasil & Itália & Chile \\
\hline 2000 & 451,4 & $1.523,8$ & 905,0 & 19,9 & 21,1 & 20,2 \\
\hline 2001 & 517,5 & $1.570,2$ & 999,0 & 20,6 & 21,2 & 21,3 \\
\hline 2002 & 537,4 & $1.299,2$ & $1.050,0$ & 20,6 & 17,7 & 22,1 \\
\hline 2003 & 536,7 & $1.326,6$ & $1.100,0$ & 20,5 & 18,3 & 22,8 \\
\hline 2004 & 548,8 & $1.418,4$ & $1.150,0$ & 20,1 & 19,8 & 23,7 \\
\hline 2005 & 572,7 & $1.661,2$ & $1.190,0$ & 21,6 & 22,5 & 22,8 \\
\hline 2006 & 585,7 & $1.505,9$ & $1.163,0$ & 22,1 & 20,8 & 23,3 \\
\hline 2007 & 612,7 & $1.354,4$ & $1.185,0$ & 21,9 & 19,2 & 23,7 \\
\hline 2008 & 585,7 & $1.368,3$ & $1.205,0$ & 21,0 & 18,7 & 21,2 \\
\hline 2009 & 560,1 & $1.400,7$ & $1.105,0$ & 19,9 & 20,0 & 22,8 \\
\hline 2010 & 592,1 & $1.361,0$ & $1.215,0$ & 21,6 & 20,0 & 23,1 \\
\hline 2011 & 644,5 & $1.212,6$ & $1.175,3$ & 21,4 & 21,8 & 21,8 \\
\hline 2012 & 603,5 & $1.042,3$ & $1.195,2$ & 22,2 & 20,6 & 22,3 \\
\hline 2013 & 551,4 & $1.108,3$ & $1.055,2$ & 21,8 & 24,1 & 19,6 \\
\hline $\begin{array}{l}\text { Média de } \\
14 \text { anos }\end{array}$ & 564,3 & $1.368,1$ & $1.120,9$ & 21,1 & 20,4 & 22,2 \\
\hline DP & 45,4 & 164,3 & 87,6 & 0,8 & 1,7 &, 2 \\
\hline
\end{tabular}

Fonte: Elaborado pela autora a partir de dados do IBGE, Odepa e Comissão Europeia

O Chile, por sua vez, tem produção elevada e apresentou bom crescimento do volume nos anos analisados. Assim, este país tem sido mais competitivo que Brasil e Itália em relação à produção. Normalmente, as boas condições climáticas impulsionam a produção de uva de mesa, ao mesmo que se houverem intempéries climáticas, a produção acaba sendo reduzida e há, também, queda na qualidade da uva. Este cenário é visto para todos os países produtores de uva de mesa (USDA, 2014a).

Apesar da produção baixa, o Brasil não está muito longe desses dois países em termos de produtividade - que remete à tecnologia no campo. A Itália, neste quesito, tem a menor produtividade média (20,4 toneladas/hectare) e o Chile, a maior (22,2 toneladas/hectare) (Tabela 16). Mas, na média, os rendimentos no campo dos três países ficaram bem próximos.

Produtores italianos de uva de mesa, em 2005, estavam investindo em tecnologias (de campo, produtos químicos etc.) para aumentar a competitividade e a produtividade. As uvas de mesa nesse país da Europa são produzidas sobre cobertura plástica para controlar a luminosidade e a temperatura. Esta cobertura permite adiantar ou atrasar a colheita de 
algumas variedades, além da proteção contra chuvas, granizos e geadas (USDA, 2014b). No Chile, também se usa esta plasticultura. No Brasil, as coberturas estão presentes apenas em parte dos parreirais do Sul e são apenas contra granizos.

$\mathrm{Na}$ Itália, ainda, especialistas relatam que o uso de mais máquinas no campo poderia reduzir em até $60 \%$ os custos de produção, mas a qualidade da fruta poderia ser prejudicada, sobretudo com maquinários para colheita (USDA, 2014b).

Em relação ao crescimento da produtividade, oscila muito para os três países nos anos analisados (Figura 35b), não podendo ser verificada uma tendência histórica. Porém, a Itália foi o único país que registrou grandes vales negativos de crescimento.

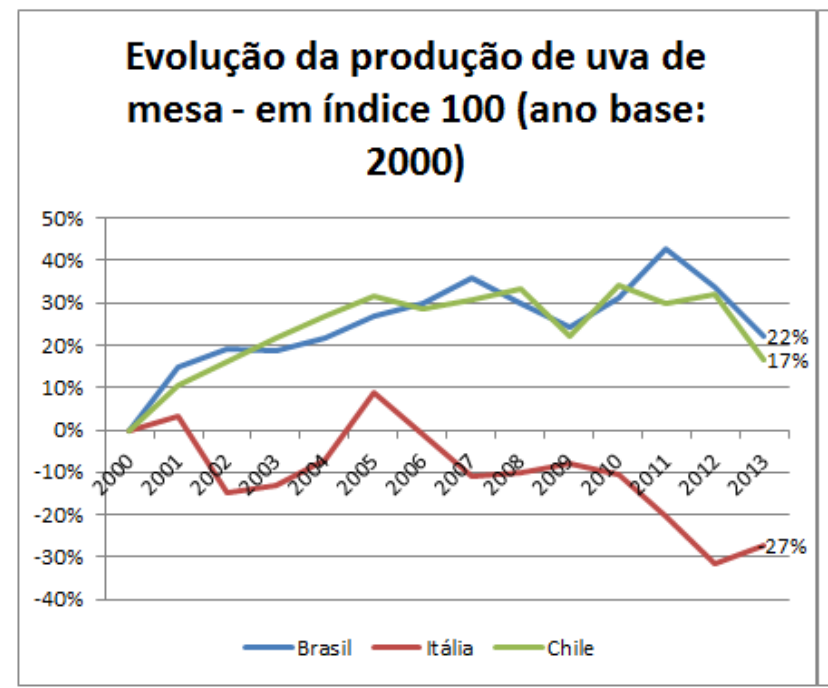

(a)

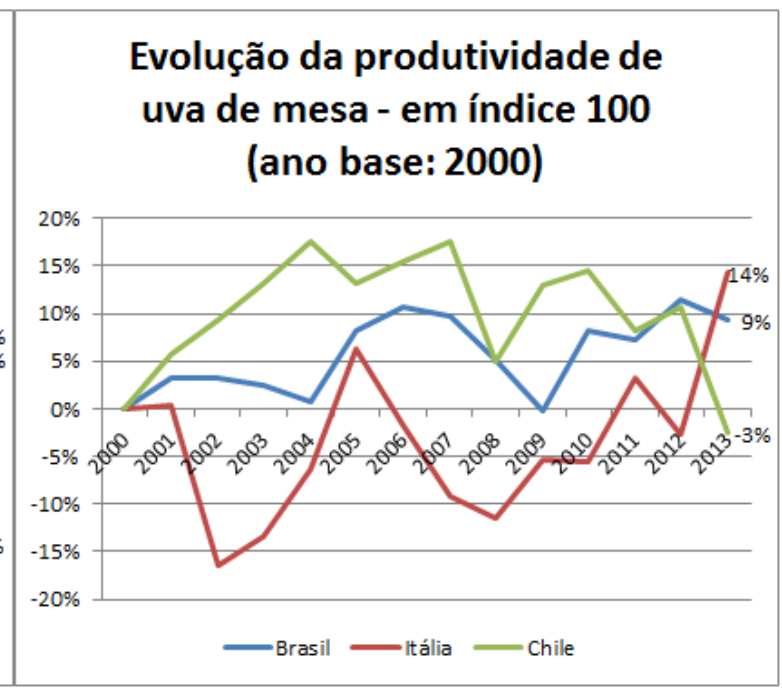

(b)

Figura 35: Evolução da produção (a) e produtividade (b) da uva de mesa de Brasil, Itália e Chile - em índice 100/ano base: 2000

Com relação à comercialização no mercado internacional, pode-se visualizar que o Brasil exportou bem pouco se comparado aos outros dois países entre 2000 e 2013 (Tabela 17). No período, as exportações brasileiras não ultrapassaram 83 mil toneladas. $O$ pico das exportações brasileiras foi em 2008, ano da crise internacional. Após esse período, com o desaquecimento das economias dos países compradores de uva de mesa do Brasil, os envios internacionais recuaram.

Na média, o Chile exporta mais que a Itália. Mas se compararmos o ano de 2000 e o de 2013, no primeiro, a Itália tinha o maior volume enviado ao comércio internacional e em 2013, o do Chile já foi maior. Assim, nota-se uma perda de competitividade da Itália frente ao Chile no mercado internacional. 
Por outro lado, a taxa de crescimento da exportação do Brasil é bem maior que a dos outros países (Figura 36a), o que mostra que, mesmo com a queda a partir de 2011, o Brasil foi o país que mais ganhou espaço no mercado internacional entre 2000 e 2013. No período, a Itália foi o único país que apresentou taxas de queda na exportação da uva fresca de mesa.

Tabela 17: Evolução das exportações e importações de uva de mesa do Brasil, Itália e Chile

\begin{tabular}{|c|c|c|c|c|c|c|}
\hline & \multicolumn{3}{|c|}{$\begin{array}{l}\text { Exportação de uva - em mil } \\
\text { toneladas }\end{array}$} & \multicolumn{3}{|c|}{$\begin{array}{c}\text { Importação de uva - em mil } \\
\text { toneladas }\end{array}$} \\
\hline & Brasil & Itália & Chile & Brasil & Itália & Chile \\
\hline 2000 & 14,3 & 607,7 & 596,2 & 9,9 & 14,3 & 0,02 \\
\hline 2001 & 20,7 & 698,9 & 545,3 & 7,5 & 12,5 & 0,01 \\
\hline 2002 & 26,4 & 476,9 & 654,9 & 11,0 & 14,3 & 0,01 \\
\hline 2003 & 37,7 & 514,5 & 706,3 & 7,6 & 16,6 & 0,02 \\
\hline 2004 & 28,9 & 452,7 & 693,1 & 6,1 & 19,6 & 0,05 \\
\hline 2005 & 51,2 & 499,6 & 738,5 & 8,4 & 19,8 & 0,00 \\
\hline 2006 & 62,3 & 451,7 & 823,2 & 12,1 & 21,2 & 0,03 \\
\hline 2007 & 79,1 & 461,3 & 776,4 & 15,5 & 23,9 & 0,23 \\
\hline 2008 & 82,2 & 534,0 & 836,9 & 12,6 & 25,1 & 0,26 \\
\hline 2009 & 54,6 & 393,3 & 850,4 & 18,7 & 23,3 & 0,29 \\
\hline 2010 & 60,8 & 478,9 & 781,1 & 24,8 & 22,9 & 0,28 \\
\hline 2011 & 59,4 & 494,8 & 853,5 & 34,1 & 22,5 & 0,18 \\
\hline 2012 & 52,0 & 482,0 & 812,2 & 33,3 & 21,5 & 0,29 \\
\hline 2013 & 43,2 & 500,2 & 856,4 & 32,6 & 18,8 & 0,22 \\
\hline $\begin{array}{l}\text { Média de } \\
14 \text { anos }\end{array}$ & 48,1 & 503,3 & 751,7 & 16,7 & 19,7 & 0,13 \\
\hline DP & 19,9 & 71,3 & 96,5 & 9,9 & 3,8 & 0,12 \\
\hline
\end{tabular}

Fonte: Elaborado pela autora a partir de dados do MDIC, Odepa e Comissão Europeia

Já em relação à importação, o Chile praticamente não compra uva de mesa de outros países (Tabela 17), enquanto Brasil e Itália importaram volumes praticamente semelhantes, na média dos anos analisados. Assim, foi comparado as taxas de crescimento em índice 100 apenas de Brasil e Itália, que são os que ainda dependem da importação de uva de mesa para abastecer parte do seu mercado consumidor. E o Brasil foi o que teve o maior crescimento entre 2000 e 2013 nas compras de uva de mesa (Figura 36b). Vale destacar que, entre 2008 e 2013, as importações brasileiras mais que dobraram, justamente no período em que a economia brasileira cresceu de modo mais acelerado que a dos países desenvolvidos. Neste mesmo cenário e período, as compras de uva de mesa da Itália recuaram. 


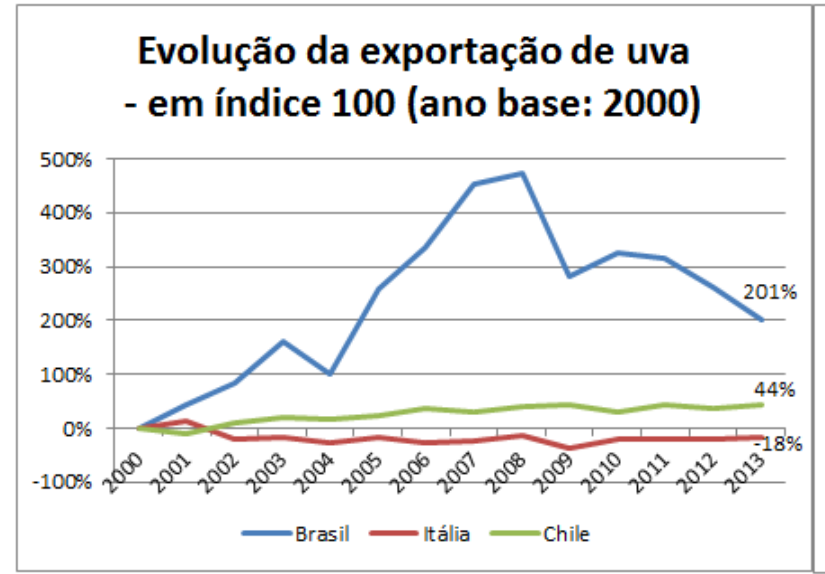

(a)

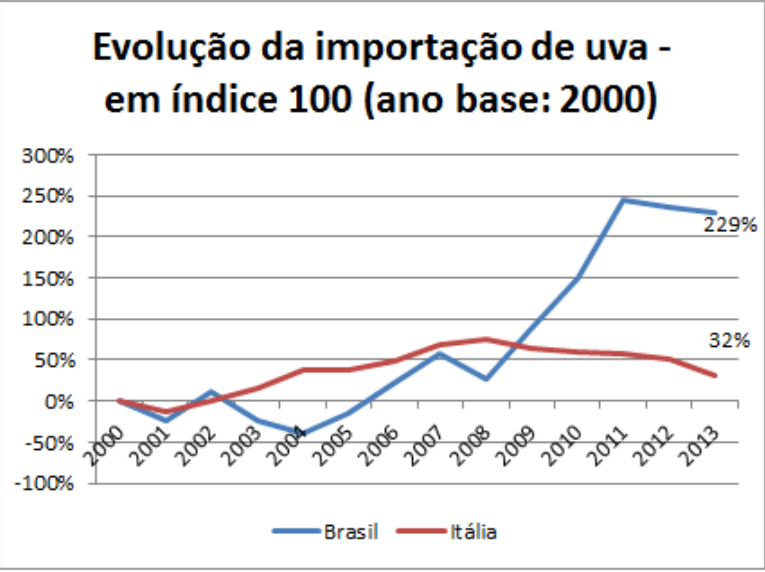

(b)

Figura 36: Evolução da exportação (a) e importação (b) da uva de mesa de Brasil, Itália e Chile - em índice 100/ano base: 2000

Em relação aos preços de comercialização no mercado internacional, foram extraídos os dados do preço da fruta negociada no porto de Roterdã, na Holanda, entre 2005 e 2014 (preço incluído o frete). Este porto é considerado a porta de entrada das frutas na União Europeia, tendo em vista que a partir dele pode-se atingir qualquer porto europeu em apenas um dia (FIGUEIREDO, 2001). Além disso, Roterdã é o maior porto do mundo (DEVELASCO; LIMA, 1999), onde também é negociado o maior volume de frutas frescas. Os três países enviam bom volume de uva para este destino, sendo possível, assim, comparar os preços da uva fresca de mesa.

Com relação às variedades exportadas para a Europa pelos três países no período, a Itália vendeu 15 tipos de uvas diferentes, sendo que seis delas foram exportadas apenas por este país, ou seja, a Itália vendeu seis variedades de uva diferentes dos outros dois países (Tabela 18). Já o Brasil, exportou 10 tipos de uvas, sendo que duas eram exclusivas e diferentes dos outros dois. O Chile, por sua vez, vendeu 8 variedades de uva para a Europa, sendo que nenhuma foi exclusiva no período. Porém, relatórios do USDA (2014a) indicam que o Chile produziu 36 variedades diferente de uva de mesa para exportação em 2008, sendo que a thompson seedless é a de maior volume.

Uma maior diferenciação das variedades de uva ofertadas no mercado internacional podem não significar elevada competitividade. Isso porque a Itália ofertou o maior número de variedades diferentes e, mesmo assim, no período analisado, foi a que mais apresentou recuo no volume exportado ao mercado internacional. 
Vale ressaltar que essa "exclusividade" é apenas entre esses três países, sendo que podem ter sido exportadas por outros produtores mundiais da uva de mesa.

Tabela 18: Variedades de uva de mesa exportadas pelo Brasil, Itália e Chile

\begin{tabular}{cccc}
\hline \multicolumn{4}{c}{ Variedades de uva de mesa exportadas para Roterdã - Holanda } \\
\hline & Brasil & Chile & Itália \\
\hline Total de variedades exportadas & 10 & 8 & 15 \\
Variedades exclusivas & $\begin{array}{c}\text { Dauphine e } \\
\text { Muscat }\end{array}$ & - & $\begin{array}{c}\text { Black Pearl, Black seedless, } \\
\text { Cardinal, Napolean, Palieri e } \\
\text { Sultana }\end{array}$ \\
\hline $\begin{array}{l}\text { Variedades em comum dos três países } \\
\text { Variedades em comum: Brasil e Chile }\end{array}$ & Crimson Seedless, Red globe, Sugraone e Thompson \\
$\begin{array}{l}\text { Variedades em comum: Brasil e Itália } \\
\text { Variedades em comum: Chile e Itália }\end{array}$ & & Alphonse, Itália e Victoria \\
\hline
\end{tabular}

Fonte: Elaborado pela autora a partir de dados do USDA

Assim, para a análise dos preços foi escolhida a uva branca sem semente (que engloba principalmente a thompson) para comparação dos três países, pois foi uma das únicas que apresentou dados para todos os anos e, também, é uma das uvas de mesa mais produzidas e exportadas do mundo.

No período analisado, as médias de preços da uva branca de mesa de Chile e Itália foram bem mais baixas que a do Brasil (Tabela 19). Segundo Ball e colaboradores (2010), o preço pode ser tomado como um parâmetro de competitividade internacional, tendo em vista que pode ser utilizado como uma medida relativa de custo de produção. No entanto, o movimento dos preços não mostram as variações do câmbio, apenas as refletem, e isto também pode impactar na competitividade internacional.

Tabela 19: Evolução do preço nominal da uva fina branca sem semente comercializada no porto de Roterdã (Holanda) - em US\$/kg

\begin{tabular}{|c|c|c|c|}
\hline \multicolumn{4}{|c|}{$\begin{array}{c}\text { Evolução do preço da uva fina branca } \\
\text { sem semente no porto de Roterdã - em } \\
\text { US\$/kg }\end{array}$} \\
\hline & Brasil & Itália & Chile \\
\hline 2005 & 3,48 & 2,18 & 2,58 \\
\hline 2006 & 4,00 & 2,72 & 1,99 \\
\hline 2007 & 4,05 & 2,84 & 2,33 \\
\hline 2008 & 2,98 & 2,76 & 2,60 \\
\hline 2009 & 4,31 & 2,30 & 2,00 \\
\hline 2010 & 4,04 & 1,48 & 2,75 \\
\hline
\end{tabular}




\begin{tabular}{cccc}
$\mathbf{2 0 1 1}$ & 4,23 & 2,85 & 2,96 \\
$\mathbf{2 0 1 2}$ & 4,32 & 2,57 & 2,81 \\
$\mathbf{2 0 1 3}$ & 3,94 & 2,93 & 3,02 \\
$\mathbf{2 0 1 4}$ & 5,07 & 2,87 & 2,91 \\
\hline $\begin{array}{c}\text { Média de 10 } \\
\text { anos }\end{array}$ & 4,04 & 2,55 & 2,59 \\
\cline { 2 - 4 } & & & \\
\hline DP & 0,55 & 0,45 & 0,38 \\
\hline
\end{tabular}

Fonte: Elaborado pela autora a partir de dados do USDA

Na comparação, porém, nota-se que em 2008 os preços dos três países foram semelhantes (Figura 37). Além disso, no comportamento dos preços, Chile e Itália praticamente seguem a mesma tendência, sendo que em quase todos os anos os preços desses dois países são muito parecidos. Vale lembrar que o frete do Chile até a Europa é maior, em valores, do que o frete italiano. Mas o Chile consegue enviar a uva para o bloco europeu com tarifas de importação de $0 \%$. Assim, o Chile consegue produzir uvas a preços mais competitivos.

Vale destacar, ainda, que o Brasil tem os maiores preços da uva no mercado internacional principalmente por dois fatores. O primeiro é a janela de mercado - o Brasil envia uva à Europa apenas na entressafra de produção dos países daquele bloco (por conta de barreiras tarifárias e ausência de acordos comerciais com a Europa), podendo vender a uva a preços maiores. Além disso, o Brasil dificilmente consegue enviar a uva a preços semelhantes ao do Chile e da Itália por conta do custo de produção elevado.

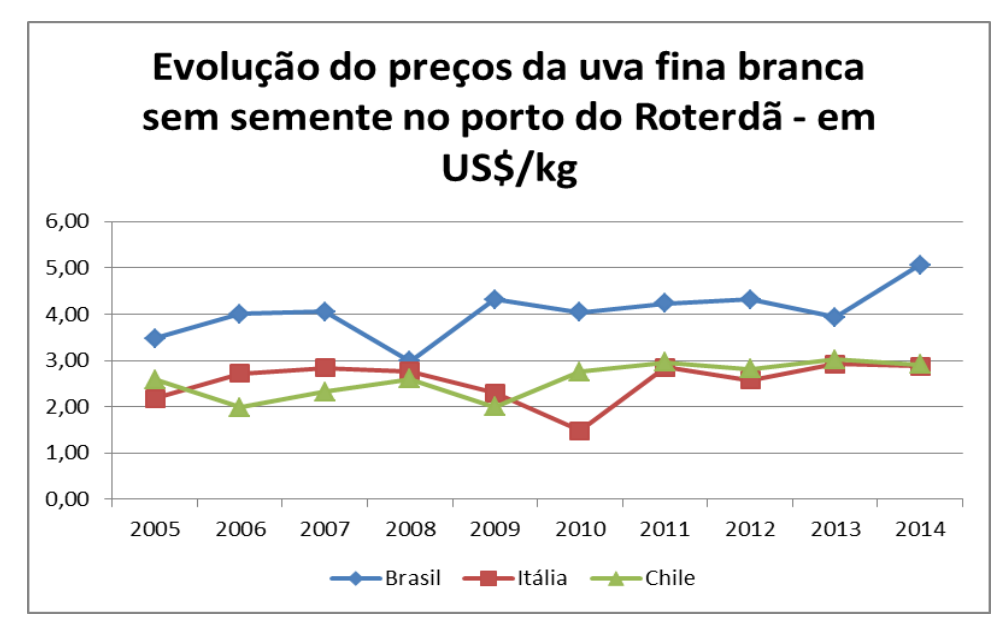

Figura 37: Evolução do preço da uva fina branca sem semente, do Brasil, Itália e Chile, comercializada no porto de Roterdã (Holanda) - em US\$/kg 
A partir dos dados acima, notou-se que o Brasil tem a menor produção e exportação frente aos outros dois países e, além disso, o Brasil importa bom volume de uva de mesa, semelhante ao da Itália. Por outro lado, para os três parâmetros, nota-se uma evolução mais positiva para o Brasil que a dos outros dois países. Assim, foi analisado, também, o consumo aparente de uva de mesa nos três países.

O consumo aparente $(\mathrm{CA})$ de uva de cada país é dado pelo volume produzido $(\mathrm{P})$, menos o exportado (E) e mais o importado (I), ou seja, CA=P-E+I. Vale ressaltar que não se contabilizam as perdas no transporte, no varejo e domiciliar para este cálculo. Assim, a Itália é o país com maior consumo aparente entre 2000 e 2013 dentre os três analisados, e o Chile é o que apresenta menor consumo (Tabela 20).

Tabela 20: Consumo aparente de uva de mesa no Brasil, Itália e Chile

\begin{tabular}{|c|c|c|c|}
\hline \multicolumn{4}{|c|}{$\begin{array}{c}\text { Consumo aparente de uva (em mil } \\
\text { toneladas) }\end{array}$} \\
\hline & Brasil & Itália & Chile \\
\hline 2000 & 446,9 & 930,4 & 308,8 \\
\hline 2001 & 504,3 & 883,8 & 453,7 \\
\hline 2002 & 522,0 & 836,6 & 395,1 \\
\hline 2003 & 506,7 & 828,8 & 393,7 \\
\hline 2004 & 526,0 & 985,3 & 457,0 \\
\hline 2005 & 529,9 & $1.181,4$ & 451,5 \\
\hline 2006 & 535,5 & $1.075,3$ & 339,8 \\
\hline 2007 & 549,2 & 917,0 & 408,9 \\
\hline 2008 & 516,0 & 859,4 & 368,4 \\
\hline 2009 & 524,2 & $1.030,7$ & 254,9 \\
\hline 2010 & 556,1 & 904,9 & 434,2 \\
\hline 2011 & 619,2 & 740,3 & 321,9 \\
\hline 2012 & 584,8 & 581,8 & 383,4 \\
\hline 2013 & 540,9 & 626,9 & 199,1 \\
\hline $\begin{array}{l}\text { Média de } 14 \\
\text { anos }\end{array}$ & 533,0 & 884,5 & 369,3 \\
\hline DP & 38,2 & 156,9 & 74,5 \\
\hline
\end{tabular}

Fonte: Elaborado pela autora a partir de dados do IBGE, MDIC, Odepa e Comissão Europeia

O consumo brasileiro per capita de uva nos lares ainda é baixo. Em 2008, foi de 0,76 $\mathrm{kg} /$ habitante/ano, em média. Porém, no Sul o consumo é maior, de 1,024 kg/habitante ao ano e o Norte tem o menor consumo, de 0,328 kg/habitante/ano (SILVEIRA, et al., 2011). Já a Itália tem o maior consumo de uva fresca de mesa da Europa, seguida pela Alemanha, Reino 
Unido e Espanha. A partir dos anos 2010, a demanda por uvas sem semente aumentou em detrimento das com semente. O consumo italiano se aproxima de $10 \mathrm{~kg} / \mathrm{habitante} / \mathrm{ano} . \mathrm{Na}$ Itália, ainda, produtores investem em embalagens e propagandas para impulsionar o consumo. Quanto ao Chile, não há dados oficiais quanto ao consumo, mas as uvas frescas que ficam no país para o consumo da população geralmente são as uvas de menor qualidade, que não foram aceitas pelos compradores internacionais (USDA, 2014b).

Dessa forma, conclui-se que o Chile produz a uva, praticamente, para exportar, já que o consumo interno é muito baixo e quase não há importação desta fruta fresca. Já a Itália, apesar do elevado consumo, vem apresentando queda neste parâmetro e baixa competitividade (Figura 38). Isso porque a produção e exportação recuaram enquanto as importações subiram no período. O Brasil, por sua vez, tem tido um mercado interno bastante atrativo, sendo o único que apresenta consumo crescente (e que não registrou picos negativos), mesmo com exportação em alta também.

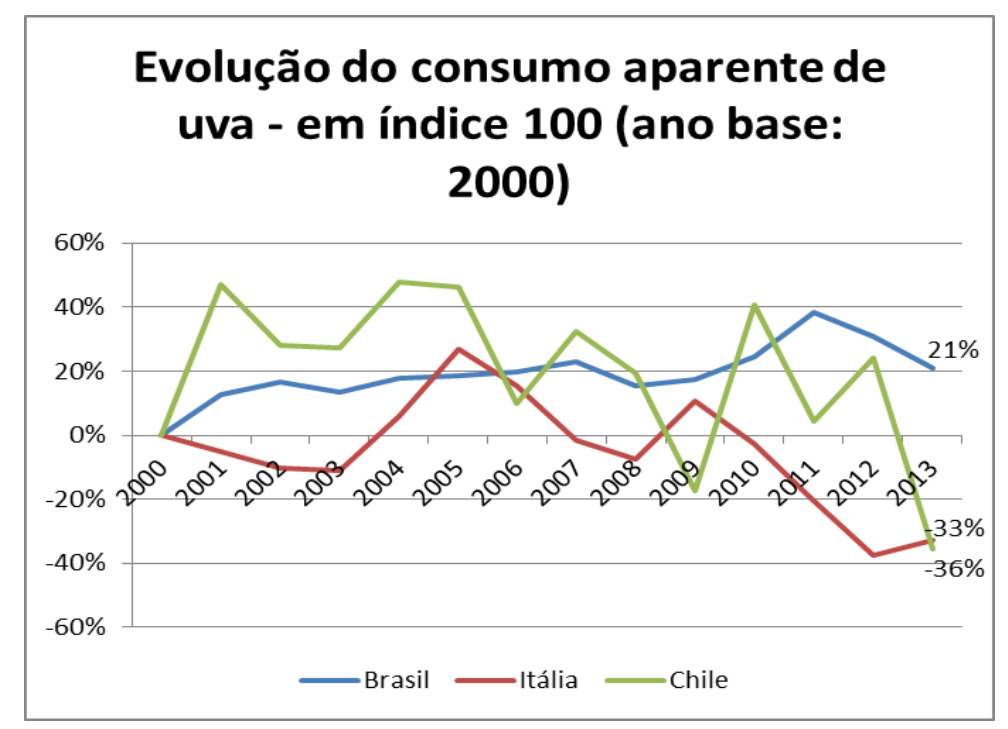

Figura 38: Evolução do consumo da uva de mesa de Brasil, Itália e Chile - em índice 100/ano base: 2000

Para comparar os parâmetros de competitividade acima dos três países analisados neste item do trabalho, foi elaborada a Tabela 21 . As notas $(-;+/-;+)$ foram dadas pela autora, de modo qualitativo.

Para a produção absoluta, a Itália teve o ponto positivo (+) tendo em vista a maior produção, o Brasil teve a menor média neste parâmetro. Já para a evolução, o Brasil saiu ganhando, tendo o ponto positivo. No parâmetro da produtividade, o Chile deteve a maior média para o período de 2000 a 2013 e o Brasil teve pontuação mediana. A pontuação da 
evolução da produtividade foi dada pelo crescimento no fim do período, tendo em vista que esta oscila muito.

Em relação ao mercado externo, o Chile é o país com maior volume médio de exportação, tendo a melhor pontuação, e o Brasil, a mais baixa. Já na evolução, o Brasil, novamente, teve melhor desempenho, ganhando mais mercado, e assim, teve a maior pontuação. Quanto às importações, o Brasil importa maior volume para abastecer o mercado interno, e, por isso, teve a nota mais baixa - a dependência da importação para abastecer a população não é um fator competitivo. Nos preços internacionais, o Brasil teve a mais baixa competitividade, adquirindo a menor pontuação neste critério.

Por fim, no consumo aparente, a média italiana é maior, mas é o Brasil que apresenta o maior crescimento da demanda interna. O Chile, neste quesito, além de ter o menor consumo interno de uva de mesa, apresenta baixo crescimento.

Tabela 21: Comparação qualitativa dos parâmetros de competitividade internacional de Brasil, Itália e Chile

\begin{tabular}{|c|c|c|c|}
\hline \multicolumn{4}{|c|}{$\begin{array}{c}\text { Comparação dos parâmetros de competitividade de Brasil, } \\
\text { Itália e Chile }\end{array}$} \\
\hline & Brasil & Itália & Chile \\
\hline Volume de produção & - & + & $+/-$ \\
\hline Evolução da produção & + & - & $+/-$ \\
\hline Produtividade média & $+/-$ & - & + \\
\hline Evolução da produtividade & $+/-$ & + & - \\
\hline Volume de Exportação & - & $+/-$ & + \\
\hline Evolução das exportações & + & - & $+/-$ \\
\hline Volume de Importação & $+/-$ & - & + \\
\hline Evolução das importações & - & $+/-$ & + \\
\hline Consumo aparente & $+/-$ & + & - \\
\hline Crescimento do consumo aparente & + & $+/-$ & - \\
\hline Preço na Europa & - & + & $+/-$ \\
\hline
\end{tabular}

Fonte: Elaborado pela autora

Assim, se somente as médias fossem avaliadas, sem levar em consideração a evolução dos dados, o Brasil seria o menos competitivo, tendo mais pontos negativos. Porém, com a evolução, nota-se que o Brasil ganhou competitividade ao longo dos anos. Por outro lado, ainda, o frete marítimo brasileiro, segundo exportadores de uva consultados nas entrevistas, é muito caro e reduz a competitividade das exportações brasileiras. Sem contar, é claro, com a 
infraestrutura dos portos, que é precária e acaba por aumentar o valor do frete por conta do tempo de espera para carregamentos nos navios.

\subsubsection{Considerações sobre a competitividade internacional}

A partir das análises realizadas nos itens anteriores, é possível discutir sobre a hipótese formulada para a competitividade internacional da uva de mesa, que foi:

O ambiente institucional é o fator que mais pesa na competitividade do mercado internacional de uva de mesa

Em relação ao ambiente institucional analisado neste trabalho, o Brasil tem baixa competitividade frente a Chile e Itália, como visto anteriormente no item 4.2.1. O Brasil tem poucos acordos de comércio estabelecidos, o que limita a competitividade internacional no que diz respeito à facilidade de entrada dos produtos brasileiros em outros países. Por outro lado, Chile e Itália têm muitos acordos firmados, o que garante maior facilidade na comercialização internacional. E a Itália, ainda, tem mais acordos, atingindo mais países que o Chile. Assim, pela hipótese, a Itália deveria ser mais competitiva no mercado global, seguida pelo Chile e, por último, o Brasil, no ranking dos três países analisados, já que a Itália e o Chile têm preços bastante competitivos e a produtividade média dos três países foi praticamente semelhante nos anos analisados.

Porém, de acordo com a análise dos dados no item 4.2.2, o Brasil evoluiu muito na competitividade internacional da uva de mesa entre 2000 e 2013 frente aos dois países em comparação, com exceção do preço de comercialização. Vitti (2009) analisou a competitividade das exportações brasileiras de frutas, dentre elas a uva, e concluiu que o Brasil ganhou mercado para a uva de mesa entre 1989 e 2006 por conta da diversificação de variedades (sobretudo a partir dos anos 2000), oferta em "janelas" de mercado (quando os principais concorrentes não produzem), expansão da infraestrutura de armazenamento e distribuição e investimentos em tecnologia no campo e marketing da uva no exterior. Em 2009, Vitti destacou, ainda, alguns pontos para que o Brasil não perdesse competitividade e conseguisse aumentá-la. Para a autora, o Brasil ainda deveria reduzir os custos para ter preços competitivos no mercado, investir em qualidade e certificações, buscar novos compradores (fora da Europa) e investir em material genético - este último já tem sido feito no Vale do São 
Francisco, conforme entrevistados deste trabalho. Uma dificuldade atual é a oferta em “janelas" de mercado, tendo em vista que nos Estados Unidos, o estado produtor da Califórnia estendeu seu período de produção, reduzindo a oportunidade de venda das uvas brasileiras naquele país - em 2009, Vitti tinha destacado os Estados Unidos como uma das principais expectativas de aumento nas vendas brasileiras. Além disso, o Peru começou a produzir uvas com competitividade e tem ofertado uva na Europa no mesmo período que o Brasil - em 2009, Vitti já tinha destacado que este país merecia atenção dos exportadores brasileiros. Este cenário mostra como o mercado internacional é dinâmico e o produtor deve sempre investir, seja em tecnologia ou em propaganda dentre outros fatores, para que a competitividade não seja reduzida a cada ano.

Já a Itália, mesmo com o forte ambiente institucional, o que, pela hipótese acima, deveria melhorar a competitividade, reduziu a produção, a exportação e o consumo interno da uva de mesa, o que remete a uma perda de competitividade da viticultura local ao longo dos anos analisados - 2000 a 2013.

Um estudo que evidencia os resultados deste trabalho foi o de Lazzarotto e Fioravanço (2013), que analisa a competitividade internacional dos principais países produtores/exportadores de uva de mesa no mundo entre 1980 e 2009 sob a ótica do desempenho, inclusive Brasil, Chile e Itália. Nas últimas três décadas analisadas, os autores constataram aumento da competição entre os países no negócio internacional de uva fresca. Os autores constataram, também, que o Brasil teve expansão na produção e no comércio nos anos analisados, enquanto a Itália teve perdas de competitividade nas exportações de uva de mesa. O Chile, por sua vez, apresentou competitividade muito superior aos demais países (com exceção do Uzbequistão), mostrando, além da alta eficiência no campo, forte especialização na cultura. Apesar disso, o Chile mostrou uma tendência de queda na competitividade revelada na comercialização da uva de mesa. No geral, para Lazzarotto e Fioravanço (2013), a qualidade e a diferenciação são dois fatores que levam a uma melhora na competitividade internacional.

Outros fatores, como os recursos, devem ser mais importantes que o ambiente institucional para a manutenção da competitividade internacional. Isso porque a Itália, que tem força neste último parâmetro, registrou queda na competitividade ao longo dos anos analisados.

No entanto, a Itália, apesar da queda na competitividade nos anos analisados, oferta pouco volume de uva para a Europa no período que o Brasil também vende as uvas naquele continente, e assim, não concorre diretamente com o Brasil no mercado europeu, segundo 
agentes do setor consultados. Para produtores/exportadores de uva, o Peru começou a ganhar espaço no mercado europeu nos últimos 10 anos e oferta a uva na Europa entre novembro e fevereiro, quando o Brasil também está comercializando no mercado internacional. Até mesmo produtores dos Estados Unidos estão incomodados com a presença do Peru no mercado internacional da uva de mesa (USDA, 2010).

A produção de uva, no geral, vem crescendo no Peru por conta da demanda internacional e do preço atrativos, e esse produto acabou se tornando um dos mais importantes do país em termos de exportação - os principais destinos são União Europeia, Estados Unidos e China. Em 2014, a produção ainda foi abaixo da brasileira, em torno de 500 mil toneladas, sendo que se exportou pouco mais de 50\% desse volume - o Peru já exporta muito mais que o Brasil nos anos mais recentes, sendo que em 2000 a exportação de uva era praticamente inexistente naquele país. O que tem impulsionado a competitividade internacional do Peru é o baixo custo com mão de obra (ainda existe oferta abundante de trabalhadores rurais, além da familiar), presença de investidores internacionais que permitiu avanço tecnológico, o clima favorável e as tarifas preferencias de importação nos principais países compradores. Em termos de produtividade no campo, a do Peru também fica em torno de 20 toneladas/hectare, nos mesmos padrões dos três países analisados neste trabalho (USDA, 2010; 2014b).

O Peru não só tem afetado as vendas brasileiras na Europa, como tem aumentado a concorrência com as negociações dos produtores chilenos com os compradores dos Estados Unidos. Por conta de uma concorrência mais acirrada, os preços da uva chilena recuaram nesse mercado (USDA, 2014b). O Chile é um grande exportador de muitas frutas de clima temperado, abastecendo Estados Unidos e Europa no período de entressafra dos seus produtos. Além disso, o Chile oferta uva de mesa ao Brasil no primeiro semestre de cada ano, concorrendo com as regiões brasileiras que ofertam no período - principalmente as paulistas de Campinas e Macro Metropolitana e o Paraná -, apesar de ofertarem variedades diferentes da fruta.

O Chile vende ao Brasil prioritariamente uvas sem semente no período que o Vale do São Francisco não produz volume para abastecer o mercado doméstico com essas variedades. E mesmo que não venda uva itália e niagara, acaba pressionando as cotações aos produtores brasileiros, tendo em vista que geralmente ofertam uma fruta de maior qualidade e valor agregado. Este é um caso de diferenciação de produto que impacta na comercialização de uvas mais comuns - o Chile produz em torno de 36 variedades de uva para exportação (USDA, 2014b). O que favorece as exportações chilenas de uva, além da tecnologia empregada nos parreiras, é o ambiente institucional, com acordos bilaterais e órgãos chilenos 
voltados ao comércio internacional. E assim como Brasil, Itália e Peru, a produção chilena também é afetada pelo clima, um fator externo não controlável.

\subsection{Análise SWOT da viticultura brasileira}

Para concluir este capítulo de resultados e discussão, é importante apresentar uma análise SWOT da viticultura brasileira, tanto nos aspectos nacionais quanto internacionais. A análise SWOT é muito utilizada na administração estratégica. Nesta análise, são descritos os pontos fortes e fracos de uma empresa/setor, que são relativos ao ambiente interno de cada organização. E por fim, as oportunidades e ameaças, que são fatores externos à firma.

Porém, a simplicidade de aplicação dessa análise oferece uma boa orientação, facilitando a compreensão e o monitoramento do setor em estudo. Esta análise, ainda, facilita a formulação de estratégias para melhorar a competitividade de um setor.

Assim, abaixo, estão identificados os pontos fortes e fracos e as oportunidades e ameaças da viticultura brasileira.

\section{- Pontos Fortes:}

○ O clima é muito favorável à produção no polo exportador do Vale do São Francisco, além da disponibilidade de água e terra;

- O Vale do São Francisco tem investido em tecnologias que permitem colheita no primeiro semestre do ano, inclusive de uvas sem semente - o que pode auxiliar a superar, em partes pelo menos, a importação do produto no período;

\section{- Pontos Fracos:}

○ Alta dependência da mão de obra para atividades de campo da viticultura;

- Depender da importação de uvas para suprir toda a demanda brasileira no primeiro semestre de cada ano;

- Baixo poder de negociação do produtor familiar, que fica a mercê dos atravessadores;

- Ambiente Institucional fraco - tanto por parte governamental quanto da atuação das associações/cooperativas, sobretudo no Sul e Sudeste do País; 


\section{- Oportunidades:}

- Demanda interna pela uva está em crescimento e o Brasil ainda tem muito espaço para o aumento no consumo de uva, tendo em vista a comparação com países da Europa, por exemplo;

- Investimentos em pesquisas de campo para a produção de uvas sem semente no primeiro semestre de cada ano para abastecer o mercado interno e depender cada vez menos da importação;

- A qualidade do produto pode ser um diferencial para o produtor, remunerando-o melhor;

- Expandir para todas as regiões brasileiras os investimentos em tecnologia e em inovações tecnológicas, como os que têm sido feitos no Vale do São Francisco;

\section{- Ameaças:}

○ O Peru tem sido uma ameaça à competitividade internacional da viticultura, não só para o Brasil, visto que tem expandido suas exportações de frutas frescas, incluindo uva, e na janela de mercado do Brasil;

○ Falta de mão de obra qualificada. 


\section{Capítulo 5 - Conclusão}

\subsection{Considerações finais}

$\mathrm{O}$ setor da viticultura no Brasil avançou significativamente nos últimos anos. $\mathrm{Na}$ competitividade do cenário doméstico, a região produtora do Vale do São Francisco, mesmo sendo a mais nova dentre as analisadas, se destacou e foi a que mais avançou em relação ao emprego de tecnologias e modernização da comercialização da década de 90 até os anos 2010. Nesta região, ainda, os produtores e empresas viticultoras têm uma visão mais voltada ao comércio global da fruta.

As regiões paulistas e a paranaense, por mais que invistam em novos modos de produção (como o sistema de condução em Y e maquinários simples), ainda estão atrasadas na adoção de tecnologias mais avançadas. Até mesmo a região de São José do Rio Preto que detém tecnologia como irrigação, ainda tem padrões de negociação mais dificultados, talvez por não predominar uma gestão mais profissional.

A irrigação é um recurso que também poderia ser adotado nas regiões de Campinas, Macro Metropolitana Paulista e do Norte do Paraná com maior intensidade, mas produtores alegam que o regime hídrico favorável e o baixo capital para investimentos de alto gasto, como é o caso da irrigação, limitam o uso. A região do Vale do São Francisco, neste quesito, tem melhor competitividade, tendo em vista que a disponibilidade de água permite que produtores adotem atividades para colher a uva o ano todo.

$\mathrm{Na}$ competitividade regional, ainda é importante destacar o papel desempenhado pelos recursos, seja do produtor ou da própria região. O Vale do São Francisco é a região que mais dispõe de recursos favoráveis (mão de obra, disponibilidade de água, terras mais baratas, tecnologias agrícolas etc), seja no campo ou na comercialização. A venda de uvas, por sua vez, ainda é um gargalo para muitos produtores familiares, paulistas e paranaenses.

O Vale do São Francisco esteve sempre em constante busca pela qualidade da uva, investindo em tecnologias disponíveis, conforme relatos durante as entrevistas. Segundo DaSilva e colaboradores (1999), nos anos 1990, quando ainda avançava a produção nordestina, 
produtores locais já tinham estratégias de priorizar a qualidade, investindo em tecnologias necessárias, que aumentavam também a produtividade no campo.

Mas, no geral, produtores de todas as regiões analisadas estão em busca constante de qualidade e boa produtividade, para que tenham rentabilidade positiva e continuem na cultura. Assim, o Vale do São Francisco investe em tecnologias, e as outras regiões têm investido em novas formas de condução do parreiral para que a mão de obra seja mais eficiente, mesmo sem tecnologias tão avançadas quanto as existentes no Nordeste.

A mão de obra ainda é um recurso limitante para maiores avanços na cultura e deve continuar sendo nos próximos anos até que surjam inovações tecnológicas que possam substituir esse trabalhador nas atividades mais delicadas. Por enquanto, os investimentos em sistemas de condução em $Y$ já amenizam esta questão, pois, além da menor necessidade de mão de obra, o sistema garante melhor ergonomia para o trabalhador e um pouco mais de sombra frente à espaldeira no período de colheita. Além disso, o sistema em $Y$ tem maior produtividade frente à espaldeira e maior espaçamento entre as plantas, o que permite atividades mecanizadas. Produtores tentam, também, qualificar a mão de obra para que a atividade seja ainda mais produtiva. Os viticultores compensam, ainda, a falta de mão de obra no campo através da mecanização parcial das propriedades.

Além dos recursos, o ambiente institucional brasileiro também afeta, mesmo que não tão positivamente, a competitividade regional. O mais evidente deste aspecto é que o produtor de uva só tem um tipo de seguro rural para contratar - contra granizo -, tendo em vista que as seguradoras privadas não querem se arriscar e não auxiliam o produtor. Falta uma pressão junto ao governo para que este cenário mude no Brasil, não só para uva, mas também para toda a fruticultura. No geral, faltam incentivos governamentais para que aumente a produção de frutas no Brasil. Os incentivos existentes são, em sua grande maioria, privados e dificilmente chegam aos produtores mais carentes. Além disso, a falta de casos de sucesso com associação/cooperativa nas regiões produtoras de São Paulo e do Paraná limitam o crescimento da competitividade, sobretudo por serem, em grande maioria, pequenos produtores.

Um fator que não pode ser esquecido, tanto na competitividade regional quanto na internacional é o clima. Assim como todos os produtos agrícolas, o clima é um dos determinantes da produtividade, e para as frutas, especialmente, da qualidade. Para uva, o clima impacta no calendário de colheita, e com isso, o Vale do São Francisco consegue colher o ano todo, enquanto, e a região de São José do Rio Preto, em período de baixa oferta de uva 
das outras regiões, o que garante a vantagem competitiva para estas duas regiões. Sobretudo no Paraná, o clima, de um modo geral, tem sido um empecilho para a produção.

Também foi constatado no trabalho que o impacto do clima na produtividade da uva não é exclusivo do Brasil, mas ocorre em outros países, como Itália, Chile e Peru. Isso pode limitar os ganhos internacionais, tendo em vista que a qualidade é um fator que pesa muito no preço da fruta.

Na competitividade internacional, ainda, o Brasil ganhou mercado nos anos analisados frente ao Chile e à Itália. Porém, não foi por conta do ambiente institucional, já que o brasileiro é fraco frente ao dos outros dois países analisados. A Itália e o Chile têm mais acordos comerciais do que o Brasil e as negociações internacionais são facilitadas por conta disso. Vale destacar, ainda, as fortes instituições governamentais e/ou privadas do Chile, que promovem as frutas daquele país no mercado global e que visam rentabilidade positiva aos produtores. Essas instituições sempre estão em busca de melhor competitividade internacional. Assim, o Chile é um dos maiores exportadores de frutas frescas do mundo.

No geral, o Brasil ganhou mais espaço no mercado internacional frente aos outros países analisados por conta da evolução tecnológica do Vale do São Francisco e por esta região ofertar a fruta em períodos de baixa concorrência na Europa.

Por outro lado, nos anos mais recentes, o Brasil (e outros países) vem perdendo espaço para o Peru na comercialização internacional, país que tem produzido a fruta no mesmo período que o Brasil - já que os dois tem clima favorável à produção estando na mesma latitude. Assim, exportadores brasileiros devem ficar atentos ao movimento do Peru.

\subsection{Limitações da pesquisa e sugestões de estudos futuros}

O presente estudo mostrou algumas limitações importantes. Primeiramente, a amostragem não pode ser extrapolada para todo Brasil. Isso porque existem inúmeras propriedades produtoras de uva de mesa no Brasil e alguns parâmetros, como rentabilidade, percepção em relação às associações/cooperativas, entre outros resultados, que são muito específicos e pessoais de cada agricultor. 
Além disso, o ambiente institucional para a viticultura é mais amplo do que foi estudado, limitando os resultados somente aos parâmetros mencionados. Por ser muito amplo, é difícil encontrar um estudo que avalie todo o ambiente institucional brasileiro.

Há de se destacar, ainda, que a avaliação estatística de apenas duas variedades de uva (itália e niagara) não remete à real rentabilidade do produtor de uva, já que muitos produtores têm um vasto portfólio de variedades em sua propriedade. Além disso, para a rentabilidade do Vale do São Francisco deve ser analisado os preços de exportação.

Por fim, na competitividade internacional, a análise poderia ser aprofundada, necessitando-se, para isso, mais informações sobre os países em destaque para que se tenha mais robustez na análise. Além disso, não há dados oficiais da produção de uva de mesa do Peru disponíveis para comparação com o Brasil, dificultando, então, a análise dos principais concorrentes do Brasil.

Vale destacar, também, algumas sugestões de estudos futuros no setor da uva de mesa. O primeiro é avaliar a capacidade de investimentos do viticultor, para verificar se seriam possíveis alguns incrementos em tecnologia neste setor para aumentar a competitividade no mercado.

Finalizando a sugestão de estudos futuros, o mercado internacional da uva ainda carece de duas explicações. A primeira delas seria uma avaliação da competitividade do Brasil frente ao Peru nas exportações de uva de mesa. A pergunta a ser respondida é: o que aconteceu naquele país para que a sua competitividade internacional nas exportações de frutas frescas tenha avançado tão rápido nos últimos anos? Uma segunda sugestão seria a de se estudar sobre a viticultura da Itália. O que ocorreu para que este país europeu tenha perdido competitividade ao longo dos anos, mesmo contando com o forte ambiente institucional onde se está inserido? 


\section{Referências Bibliográficas ${ }^{17}$}

ABRAS. Associação Brasileira de Supermercados. Disponível em: <http://www.abras.com.br/> Acesso em 28 out 2014

ADUANA. Serviço de Aduanas do Governo do Chile. Disponível em: <http://www.aduana.cl> Acesso em 14 abr 2015

AGROINDUSTRIAIS, Programa SEBRAE de Cadeias Produtivas. Estudo da Cadeia Produtiva de Fruticultura do Estado da Bahia - Análise das Principais Cadeias Produtivas de Frutas e da Fruticultura Orgânica no Contexto Baiano. IBRAF, janeiro, 2005.

AKAIKE, H. A new look at the statistical model identification. Automatic Control, IEEE Transactions on, v. 19, n. 6, p.716-723, 1974.

ALBERGONI, L.; PELAEZ, V. Da Revolução Verde à agrobiotecnologia: ruptura ou continuidade de paradigmas? Revista de Economia, v. 33, n. 1 (ano 31), p. 31-53, jan./jun. 2007.

ALCHIAN, A. A.; DEMSETZ, H. Production, Information Costs, and Economic Organization. The American Economic Review, Vol. 62, N. 5, p. 777-795. 1972

ALMEIDA, L.F.; ZYLBERSZTAJN, D. Crédito Agrícola no Brasil: uma perspectiva institucional sobre a evolução dos contratos. Revista Eletrônica de Negócios Internacionais, São Paulo, v. 3, n. 2, p. 267-287, ago./dez. 2008.

ALMEIDA, P.F.M. Amostragem. In: PERDIGÃO, D.M.; HERLINGER, M.; WHITE, O.M. Teoria e Prática da Pesquisa Aplicada. Rio de Janeiro: Elsevier, 2011. 475 p.

\footnotetext{
${ }^{17}$ De acordo com a Associação Brasileira de Normas Técnicas. NBR 6023.
} 
ANFAVEA. Associação Nacional dos Fabricantes de Veículos Automotores. Estatísticas. Disponível em: <http://www.anfavea.com.br/tabelas2013.html> Acesso em: 23 set 2014

ARATANGY, V.L.F. Dados Secundários. In: PERDIGÃO, D.M.; HERLINGER, M.; WHITE, O.M. Teoria e Prática da Pesquisa Aplicada. Rio de Janeiro: Elsevier, 2011. 475 p.

ARAÚJO, J.L.P.; CORREIA, R.C. Análise do custo de produção e rentabilidade do cultivo da uva fina de mesa sem sementes produzida na região do Submédio São Francisco. XIII Simpósio de Engenharia de Produção (SIMPEP), Bauru, São Paulo, 2008.

ASOEX. Asociación de Exportadores de Frutas de Chile A.G. Disponível em: <http://www.asoex.cl/> Acesso em: 08 jun 2015

AZEVEDO, P. F.. A nova economia institucional: níveis analíticos. In: FARINA, E.M.M.Q.; AZEVEDO, P.F.; SAES, M.S.M. Competitividade: mercado, estado e organizações. São Paulo: Editora Singular, 1997. 286 p.

AZEVEDO, P.F. Nova economia institucional: referencial geral e aplicações para a agricultura. Agricultura em São Paulo, São Paulo, v. 47, n. 1, p. 33-52, 2000.

BALL, V.E.; BUTAULT, J.P.; JUAN, C.S.; MORA, R. Productivity and international competitiveness of agriculture in the European Union and the United States. Agricultural Economics, v. 41, p. 611-627. 2010.

BANCO CENTRAL DO BRASIL. Anuário Estatístico do Crédito Rural 2012. Disponível em: <https://www.bcb.gov.br/?RELRURAL2012> Acesso em: 20 jun 2015

BARBOSA-FILHO, F.H. Nota Sobre Evolução da Produtividade no Brasil. Instituto Brasileiro de Economia da Fundação Getúlio Vargas (IBRE-FGV). Nota Técnica, Fev. 2014 
BARRETO-JÚNIOR, D. Análise crítica do desempenho das Centrais de Abastecimento Ceasas. Anais da Academia Pernambucana de Ciência Agronômica, Recife, vol. 1, p.2026, 2004.

BARNEY, J. Firm resources and sustained competitive advantage. Journal of Management, v. 17, n. 1, p. 99-120.1991.

Resource-based theories of competitive advantage: A ten-year retrospective on the resource-based view. Journal of Management, v. 27, p. 643-650, 2001.

BARRIENTOS, A.; BARRIENTOS, S.W. Extending social protection to informal workers in the horticulture global value chain. Washington, DC: World Bank, Jun, 2002

BARROS, M.H.C.; BOTEON, M. Avaliação do desempenho regional dos principais pólos produtores de uva no Brasil. In: $40^{\circ}$ Congresso da Sociedade Brasileira de Economia, Administração e Sociologia Rural, Passo Fundo - RS. Anais... BRASÍLIA: SOBER. 2002.

BELIK, W.; REYDON, B.P.; SEBASTIÃO-NETO, R.G. Instituições, ambiente institucional e políticas agrícolas. p. 103-140. In: Ramos, P. (org.). Dimensões do agronegócio brasileiro: políticas, instituições e perspectivas. Brasília: MDA, 2007. 360 p.

BLOOM, N.; MAHAJAN, A.; MCKENZIE, D.; ROBERTS, J. Why do firms in developing countries have low productivity? The American Economic Review, v. 100, n. 2, p. 619-623, may, 2010.

BRASIL. Lei n ${ }^{\circ} 11.326$, de 24 de julho de 2006. Estabelece as diretrizes para a formulação da Política Nacional da Agricultura Familiar e Empreendimentos Familiares Rurais. Diário Oficial da União. 2006

BRASIL. Ministério da Agricultura, Pecuária e Abastecimento. Cadeia produtiva de frutas. Antônio Márcio Buainain e Mário Otávio Batalha (coordenadores). Brasília: IICA: MAPA/SPA, 2007. 102 p. 
BÊRNI, D.A.; LAUTERT, V. Mesoeconomia: Lições de contabilidade social - a mensuração do esforço produtivo na sociedade. Porto Alegre: Bookman, 2012.

BUAINAIN, A.M.; ROMEIRO, A.R.; GUANZIROLI, C. Agricultura Familiar e o Novo Mundo Rural. Sociologias, Porto Alegre, ano 5, n. 10, p. 312-347, jul/dez, 2003.

BUAINAIN, A.M. Modelo e principais instrumentos de regulação setorial: uma nota didática. p. 53-102. In: Ramos, P. (org.). Dimensões do agronegócio brasileiro: políticas, instituições e perspectivas. Brasília: MDA, 2007. 360 p.

CAMARGO, U. A.; TONIETTO, J.; HOFFMANN, A. Progressos na Viticultura Brasileira. Revista Brasileira de Fruticultura, Jaboticabal - SP, Volume Especial, E. 144-149, Outubro 2011.

CAPELLO, F.P. Especial frutas: Niagara toma espaço da uva fina no estado de São Paulo. Revista Hortifruti Brasil, Ano 13, n. 140, p. 8-20, novembro, 2014.

CARRER, H.; BARBOSA, A.L.; RAMIRO, D.A. Biotecnologia na agricultura. Estudos Avançados, v. 24, n.70, p. 149-164, 2010

Cati. Coordenadoria de Assistência Técnica Integral. Disponível em: $<$ http://www.cati.sp.gov.br> Acesso em 27 out 2014

CAVALCANTI, J.S.B. Frutas para o mercado global. Estudos Avançados, v.11, n.29, p.7993, São Paulo, Jan/Abr. 1997.

CEPEA. Centro de Estudos Avançados em Economia Aplicada. PIB do Agronegócio. Disponível em: <http://cepea.esalq.usp.br/pib/> Acesso em 24 jun 2014

CHADDAD, F.R.; JANK, M.S.; NAKAHODO, S.N. Repensando as Políticas Agrícola e Agrária do Brasil. ICONE e IBMEC, 1-43, 2006. 
CLÍMACO, P.; LOPES, C.M.; CARNEIRO, L.C.; CASTRO, R. Efeito da casta e do portaenxerto no vigor e na produtividade da videira. Ciência e técnica vitivinícola, v. 18, n. 1, p. $1-14,2003$.

COMISSÃO EUROPEIA. Banco de dados Eurostat. Disponível em: <http://epp.eurostat.ec.europa.eu/portal/page/portal/statistics/search_database> Acesso em: 3nov 2014

COOK, M.L.; CHADDAD, F.R. Agroindustrialization of the global agrifood economy: bridging development economics and agribusiness research. Agricultural Economics, v. 23, p. 207-218, 2000.

CORDEIRO, G.M.; DEMÉTRIO, C.G.B. Modelos Lineares Generalizados e Extensões. Arquivos da Escola Superior de Agricultura Luiz de Queiroz (Esalq), Universidade de São Paulo (USP), Piracicaba, SP. 2013. 493 p.

CUNHA FILHO, M.H. da.; CARVALHO, R.M. Exportações brasileiras de frutas: diversificação ou concentração de produtos e destinos?. Anais do XLIII Congresso Brasileiro de Economia e Sociologia Rural, Ribeirão Preto, SP. 2005.

DA-SILVA, P.C.G.; LEÃO, P.C.S.; CERDAN, C.; SAUTIER, D.; CHOUDHURY, M.M.; BENTZEN, M.C.P.; BARRETO, M.C. A cadeia produtiva da uva de mesa do Nordeste do Brasil. Embrapa Semiárido - Capítulo em livro técnico-científico (ALICE), 1999. Disponível em: 〈http://www.alice.cnptia.embrapa.br/alice/bitstream/doc/133377/1/Pedro.pdf>

DA-SILVA JR, A. G.; FALCETTE, A. H.; NOGUEIRA, M.; BUNGENSTAB, D.; MASCOTENA, A.; CHORKULAK, V.; ZANASI, C.; SEVERI, C.R.C.; SCHIEFER, G.; LEHMANN, R.; SEBOK, A.; LOZANO, M.S.R. Desafios da sustentabilidade nas cadeias de soja e gado de corte. Apostila. Projeto Salsa - América Latina e União Europeia. Disponível em: <http://www.salsaproject.eu/> Acesso em: 16 dez 2014

DAVIS, J.H.; GOLDBERG, R.A. The nature of Agribusiness (Chapter 2).In: A concept of agribusiness. Harvard University, Boston, 1957. 
DELEO, J.P.B.; BOTEON, M.; FERREIRA-SILVA, A.; BARROS, G.S.C.; RIBEIRO, R.G.; CAPELLO, F.P.; VIANA, M.; LOURENCINI, I.; SOARES, A. Gestão sustentável - uva: Vale do São Francisco de olho no consumidor brasileiro. Revista Hortifruti Brasil, ano 11, n. 118, p. 8-25, novembro, 2012.

DEMSETZ, H. Towards a theory of property rights, American Economic Review, v.57, n.2, p.347-359, May 1967.

DE-VELASCO, L.O.M.; LIMA, E.T. As novas empresas mundiais de navegação determinam a evolução dos portos. Revista BNDES, n.11, 1999.

DICKEN, P. Mudança Global: mapeando as novas fronteiras da economia mundial. $5^{\text {a }}$ edição. Porto Alegre: Bookman, 2010. 632 p.

DOMINGUES, M.; DOMINGUES, J. Estatística Exploratória. Vol. 1,Universidade Federal Rural de Pernambuco (UFRPE). Recife, 2010.54 p.

DOSI, G. Technological paradigms and technological trajectories: A suggested interpretation of the determinants and directions of technical change. Research Policy.v. 11, n. 3, p. 147162, junho, 1982.

DUARTE, R. Entrevistas em pesquisas qualitativas. Educar, Curitiba, n. 24, p. 213-225, 2004. Editora UFPR

Emater. Instituto Paranaense de Assistência Técnica e Extensão Rural. Disponível em: <http://www.emater.pr.gov.br> Acesso em: 28 out 2014

Embrapa. Empresa Brasileira de Pesquisa Agropecuária. Disponível em: <https://www.embrapa.br/uva-e-vinho> Acesso em: 28 out 2014a

Embrapa. Empresa Brasileira de Pesquisa Agropecuária. Cultivo da videira. Disponível em: <sistemasdeproducao.cnptia.embrapa.br/Uva/CultivodaVideira> Acesso em: 38 out 2014b 
ESPERANCINI, M.S.T.; PEROSA, J.M.Y; ROCHA, P. Caracterização do mercado e fatores que interferem na competitividade da uva fresca no estado de São Paulo. In: Congresso Brasileiro da Sociedade Brasileira de Economia e Sociologia Rural (Sober), vol. 42, 2004. Disponível em: 〈http://www.sober.org.br/palestra/12/01P065.pdf>

European Comission. Página oficial da União Europeia. Disponível em: 〈http://ec.europa.eu> Acesso em 14 abr 2015.

Export Helpdesk. European Comission. Tariffs. Disponível em: <http://exporthelp.europa.eu/thdapp/index.htm?newLanguageId=EN> Acesso em: 14 jul 2014

EYLER, R.C. The International Competitiveness of the California Wine Industry.Working Paper.Sonoma State University, Department of Economics. 1999. Acesso em: 15 set. 2014. Disponível em: <http://hdl.handle.net/10211.1/459>

FAO.Food and Agriculture Organization of the United Nations.Production quantities by country.Faostat.Disponível em: <http://faostat3.fao.org/> Acesso em: 24 jun 2014

FARIAS, A.M.L.; LAURENCEL, L.C. Números índices. Universidade Federal Fluminense, mai, 2005. 90 p. Disponível em: <http://www.uff.br/ieeanamariafarias/numerosindices.pdf>

FARINA, E.M.M.Q. Competitividade e coordenação de sistemas agroindustriais: um ensaio conceitual. Gestão \& Produção, v.6, n.3, p. 147-161, dez. 1999

FARINA, E.M.M.Q.; ZYLBERSZTAJN, D. Relações tecnológicas e organizações dos mercados do Sistema Agroindustrial de alimentos. Cadernos de Ciência \& Tecnologia, Brasília, v.8, n. 1/3, p.9-27, 1991.

FAVERET-FILHO, P.; ORMOND, J.G.P.; PAULA, S.R.L. de. Fruticultura brasileira: a busca de um modelo exportador. BNDES, 1998.

FELDMANN, P.R. O atraso tecnológico da América Latina como decorrência de aspectos geográficos e de fatores microeconômicos interligados. Economia e Sociedade, Campinas, v. 18, n. 1 (35), p. 119-139, abr. 2009. 
FELEMA, J.; RAIHER, A. P.; FERREIRA, C. R. Agropecuária brasileira: desempenho regional e determinantes de produtividade. Revista de Economia e Sociologia Rural, v.51, n.3, p. 555-573, 2013.

FERRAZ, J.C.; KUPFER, D.; HAGUENAUER, L. Made in Brazil: Desafios competitivos para a indústria. Rio de Janeiro: Campus, 1995

FERREIRA, D. F. Estatística Básica. Editora UFLA, 2 edição. 2009. 664 p.

FIGUEIREDO, G.S. O papel dos portos concentradores na cadeia logística global. Anais do XXI Encontro Nacional de Engenharia de Produção, Abepro, Bahia, 2001.

FIORAVANÇO, J.C. Maçã brasileira: da importação à auto-suficiência e exportação - a tecnologia como fator determinante. Informações Econômicas, São Paulo, v.39, n.3, mar. 2009.

FRENKEL, J.; SILVEIRA, J.M.; FIANI, R.; PAULINO, S. Tarifas, preços e a estrutura industrial dos insumos agrícolas: o caso dos defensivos. Texto para discussão ${ }^{\circ}{ }^{\circ} 412$. Instituto de Pesquisa Econômica Aplicada (IPEA). Brasília, 1996

Fundecitrus. Fundo de Defesa da Citricultura. CTNBio aprova cultivo de laranja transgênica para pesquisa. Disponível em: <http://www.fundecitrus.com.br/pdf/midias/256201305311805.pdf> Acesso em: 25 set 2014

GASQUES, J.G.; CONCEIÇÃO, J.C.P.R. Indicadores de competitividade e de comércio exterior da agropecuária brasileira. Brasília: Instituto de Pesquisa Econômica Aplicada, $\mathrm{n}^{\circ}$ 908, set. 2002. (IPEA. Texto para discussão).

GASQUES, J.G.; REZENDE, G.C.; VERDE, C.M.V.; SALERNO, M.S.; CONCEIÇÃO, J.C.P.R.; CARVALHO, J.C.S. Desempenho e crescimento do agronegócio no Brasil. Brasília: Instituto de Pesquisa Econômica Aplicada, fev. 2004. 39 p. (IPEA. Texto para discussão, 1.009). 
GASQUES, J.G.; BASTOS, E.T.; BACCHI, M. Produtividade e Crescimento da Agricultura Brasileira. pg. 72-75. In: Informe Agronegócios, Edição 6, Instituto de Cooperação para Agricultura (IICA). 2009

GASQUES, J.G.; BASTOS, E.T.; VALDES, C.; BACCHI, M. Produtividade e Crescimento Algumas Comparações. In: ALVES, E. R. A., SOUZA, G. S. e GOMES, E. G. Contribuição da Embrapa para o desenvolvimento da agricultura no Brasil. Brasília, DF: Embrapa, 2013

GIBBONS, J. D.. CHAKRABORTI, S. Nonparametric Statistical Inference. Marcel Dekker Inc, fourth edition, revised and expanded edition. 2003.

GIL, A. C. Como elaborar projetos de pesquisa. São Paulo: Atlas, 5ª ed., 2010, 200 p.

GODOY, A.S. Pesquisa qualitativa: tipos fundamentais. Revista de Administração de Empresas, v. 35, n. 3, p. 20-29, São Paulo. Mai./jun. 1995

GRANGEIRO, L.C.; SORAES, J.M.; REIS, C.S.; DI-GALVANINI, F.; CRUZ-DA-SILVA, A.V. Armazenamento refrigerado de uva, cultivar Superior Seedless produzida no Vale do São Francisco. XVII Congresso Brasileiro de Fruticultura. Belém: SBF/EMBRAPA, 2002.

GRAY, E.; JACKSON, T.; ZHAO, S. Agricultural Productivity: Concepts, measurement and factors driving it a perspective from the ABARES productivity analyses. Rural Industries Research and Development Corporation, Australian Government, n. 10, 56 p., mar. 2011

GREENWOOD, J. The Third Industrial Revolution: Technology, Productivity, and Income Equality. Economic Review, v. 35, n. 2, p. 2- 12, 1999.

HARISSON, R.W.; KENNDY, P.L. A neoclassical economic and strategic management approach to evaluating global agribusiness competitiveness. Competitiveness Review: An International Business Journal, v. 7, n. 1 p. $14-25.1997$

HOWELL, G.S. Sustainable grape productivity and the growth-yield relationship: A review. American Journal of Enology and Viticulture, v.52, n.3: p. 165-174, 2001. 
IBGE.Instituto Brasileiro de Geografia e Estatísticas. Censo Agropecuário 2006. Disponível em: 〈http://ibge.gov.br>

IBGE. Instituto Brasileiro de Geografia e Estatística. SIDRA - banco de dados. Disponível em: <http://www.sidra.ibge.gov.br/bda/tabela/listabl.asp?z=t\&c=1613> Acesso em: 24 jun 2014

INGLEZ-DE-SOUSA, J.S. Uvas para o Brasil. Julio Seabra Inglez de Sousa (coordenação). Piracicaba: Fealq, 1996. 791 p.

JAMES, C. Brief 43: Global Status of Commercialized Biotech/GM Crops: 2011. International Service for the Acquisition of Agri-biotech Applications (Isaaa). 2011 Disponível em: <http://www.isaaa.org/resources/publications/briefs/43/download/isaaa-brief43-2011.pdf>

KUPFER, D. Padrões de concorrência e competitividade. Encontro Nacional da ANPEC, v. 20, p. 1, 1992.

LAVILLE, C.; DIONNE, J. A construção do saber: manual de metodologia da pesquisa em ciências humanas. Porto Alegre: Artmed, 1999. 340 p.

LAZZAROTTO, J.J.; FIORAVANÇO, J.C. Dinâmica da competitividade dos principais países exportadores de uva de mesa. Informações Econômicas, SP, v. 43, n. 2, p. 68-81, mar/abr, 2013.

MACEDO, L.O.B.; PACHECO, A.B.; SANTO, E.S.E. A evolução do Programa de Subvenção do Prêmio do Seguro Rural: uma avaliação do período 2006-10. Indicadores Econômicos FEE, Porto Alegre, v. 40, n. 4, p. 99-112, 2013.

MAGAlHÃES, M. N.; DE LIMA, A. C. P. Noções de Probabilidade e Estatística. Editora da Universidade de São Paulo, 7a edição. 2010.

MALHOTRA, N.K. Pesquisa de marketing: uma orientação aplicada. $6^{a}$ edição. Porto Alegre: Bookman, 2012. 719 p. 
MANSFIELD, E. Microeconomia: teoria e aplicações. Rio de Janeiro: Campus, 1978. 481 p.

MAPA. Ministério da Agricultura, Pecuária e Abastecimento. Exportação. Disponível em: <http://www.agricultura.gov.br/vegetal/exportacao> Acesso em: 21 out 2014

- Ministério da Agricultura, Pecuária e Abastecimento. Disponível em: <http://www.agricultura.gov.br > Acesso em: 13 jan 2015

MARCONI, E.M.; LAKATOS, M.A. Fundamentos de metodologia científica. $5^{\text {a }}$ ed. São Paulo: Atlas, 2003. 311 p.

MARTINS, V.A.; MARGARIDO, M.A.; BUENO, C.R.F. Alteração no perfil de compra de frutas, legumes e verduras nos supermercados e feiras livres na cidade de São Paulo. Informações Econômicas, São Paulo, v.37, n.2, fev, 2007

MATTEI, L.; TRICHES, V.. Análise da competitividade da cadeia vitivinícola do Rio Grande do Sul através do ambiente institucional. Análise Econômica, Porto Alegre, ano 27, n. 52, p. 161-183, setembro, 2009

MDIC. Ministério do Desenvolvimento, Indústria e Comércio Exterior. Disponível em: <www.mdic.gov.br> Acesso em: 20 jan 2015

Ministério do Desenvolvimento, Indústria e Comércio Exterior (MDIC)/Secretaria de Comércio Exterior (Secex). Sistema de Análise das Informações de Comércio Exterior (Aliceweb). Disponível em: <http://aliceweb.mdic.gov.br> Acesso em 31 jun 2014

MÉDICI, A. Família na agricultura: indivíduos, projetos, pequena empresa e competitividade. Revista Ciência em Extensão, v.5, n.2, p.60-72, 2009. 
MILGROM, P.; ROBERTS, J. Economic Theories of the Firm: Past, Present, and Future. In BUCKLEY, P.J.; MICHIE, J. Firms, Organizations and Contracts. Oxford University Press, 1996

MORAES, R. Análise de conteúdo. Revista Educação, Porto Alegre, v. 22, n. 37, p. 7-32, 1999.

MORAL, R. A.; HINDE, J.; DEMÉTRIO, C.G.B. hnp: Half-Normal Plots with Simulation Envelopes. R package version 1.0. 2014

MUHR, T. ATLAS/ti - A prototype for the support of text interpretation. Qualitative Sociology, vol. 14, n.4, 1991.

NELDER, J.A.; WEDDERBURN, R.W. M. Generalized linear models. Journal of the Royal Statistical Society. Series A (General), v. 135, n. 3, p.370-384, 1972

NEVES, J.L. Pesquisa qualitativa - características, usos e possibilidades. Cadernos de Pesquisa em Administração, São Paulo, v. 1, n. 3, $2^{\circ}$ sem., 1996.

NOGUEIRA, A.C.L. Mecanização na agricultura brasileira: uma visão prospectiva. Caderno de Pesquisas em Administração, São Paulo, v. 08, n. 4, outubro/dezembro. 2001.

NOGUEIRA, A.C.L.; ZYLBERSZTAJN, D. Coexistência de arranjos institucionais na avicultura de corte do estado de São Paulo. WorkingPaper $\mathrm{n}^{\circ}$ 03/022. Série de WorkingPapers. Disponível em: <http://www.ead.fea.usp.br/WPapers/2003/03-022.pdf> Acesso em: 8 set. 2014

NORTH, D.C. Institutions. Journal of Economic Perspectives, vol 5, n.1, Winter, p. 97-112. 1991.

Prize lecture: economic performance through time. Lecture to the memory of Alfred Nobel, December 9, 1993. Disponível em: <http://www.nobelprize.org/nobel_prizes/economic-sciences/laureates/1993/northlecture.html> 
Economic Performance Through Time. The American Economic Review, vol 84. Issue 3, june, 359-368. 1994.

ODEPA. Oficina de Estudios y Políticas Agrarias. Chile. Disponível em: <http://www.odepa.cl/estadisticas/productivas/> Acesso em: 31 mar 2015

OLSSON, M.; SVENSSON, P. Agricultural growth and institutions: Sweden, 1700-1860. European Review of Economic History, v. 14, p. 275-304. 2010

PADILLA-BERNAL, L.E.; RUMAYOR-RODRIGUEZ, A.; PEREZ-VEYNA, O.; REYESRIVAS, E. Competitiveness of Zacatecas (Mexico) Protected Agriculture: The Fresh Tomato Industry. International Food and Agribusiness Management Review, v. 13, Issue 1, 2010

PICKTON, D.W.; WRIGHT, S. What's swot in strategic analysis? Strategic Change, v. 7, p. 101-109, 1998

PIMENTEL, A. O método da análise documental: seu uso numa pesquisa historiográfica. Cadernos de Pesquisa, n. 114, p.179-195, novembro, 2001

PINDYCK, R.S.; RUBINFELD, D.L. Microeconomics. $3^{a}$ edição. Prentice Hall, 1994. 699 p.

PIRES, M. L.; CAVALCANTI, J.S. Cooperativismo, fruticultura e dinâmicas sociais rurais: Uma nova onda de cooperativas no Vale do São Francisco. In.: SILVA, A.; CAVALCANTI, J.S.; WANDERLEY, M.N. Diversificação dos espaços e dinâmicas territoriais no Nordeste do Brasil. João Pessoa, Zarinha Centro de Cultura, 2009, p. 115-135.

PORTER, M. E. Vantagem Competitiva: criando e sustentando um desempenho superior. Rio de Janeiro: Campus, 1990. 512 p.

Vantagem competitiva das nações. Rio de Janeiro, Campus. 897 p. 1993

Why is Strategy? Harvard Business Review, v. 74, n. 6, p. 61-78, november/december, 1996. 
The five competitive forces that shape strategy. Harvard Business Review, v. 86, n. 1, p. 25-40, january, 2008.

R Core Team. R: A Language and Environment for Statistical Computing. R Foundation for Statistical Computing, Vienna, Austria. 2014

RECH, S.R.; Modelo Conceitual de Análise Competitiva em Micro e Pequenas Empresas do Setor de Confecções. Ciências Jurídicas e Empresariais, v. 10, n. 1, p. 5-12, Mar. Londrina, 2009

Revista Exame. Ranking das 50 maiores empresas do agronegócio em 2011. Disponível em: $<$ http://exame.abril.com.br/negocios/noticias/as-50-maiores-empresas-do-agronegocio-em2012> Divulgado em: 05 jul. 2012

ROMBALDI, C.V.; FERRI, V.C.; BERGAMASQUI, M.; LUCHETTA, L.; ZANUZO, M.R. Produtividade e qualidade de uva, cv. bordô (ives), sob dois sistemas de cultivo. Revista Brasileira de Agrociência, v.10, n. 4, p.519-521, out-dez, 2004.

ROSA, A.V. Agricultura e Meio Ambiente. São Paulo: Atual. 1998.

SAES, M.S.M.. Estratégias de diferenciação e apropriação da quase-renda na agricultura: a produção de pequena escala. Tese (Livre Docência) - Universidade de São Paulo, 2008, 162 p.

SAITONE, T.L.; SEXTON, R.J. Product Differentiation and Quality in Food Markets: Industrial Organization Implications. Annual Review of Resource Economics, v. 2, n. 1, p. 341-368. 2010.

SAMPIERI, R.H.; COLLADO, C.F.; LUCIO, P.B. Metodologia de Pesquisa. $3^{\text {a }}$ edição. São Paulo: McGraw - Hill, 2006. 583 p.

SATO, G.S. Análise do consumo de uva para mesa no Brasil. Informações Econômicas, v.34, n.7, p. 50-53, 2004.

SÁ-SILVA, J.R.; ALMEIDA, C.D.; GUINDANI, J.F. Pesquisa documental: pistas teóricas e metodológicas. Revista Brasileira de História \& Ciências Sociais, Ano 1, n.1, julho, 2009 
SILVA, E.L.; MENEZES, E.M. Metodologia da pesquisa e elaboração de dissertação. $4^{\text {a }}$ edição. Florianópolis: UFSC, 2005. 138p.

SILVA, M. F. O.; COSTA, L. M. A indústria de defensivos agrícolas. Cadernos BNDES Setorial, v. 35, p. 233-276, 2011

SILVEIRA, J.M.F.J.; BORGES, I.C.; BUAINAIN, A.M. Biotecnologia e Agricultura: da ciência e tecnologia aos impactos da inovação. São Paulo em Perspectiva, v. 19, n. 2, p.101114, abr./jun. 2005

SILVEIRA, J.; GALESKAS, H.; TAPETTI, R.; LOURENCINI, I. Quem é o consumidor brasileiro de frutas e hortaliças? Revista Hortifruti Brasil, Ano 10, n. 103, p. 8-23, jul. 2011

SOUZA, R.A.M.; SILVA, R.O.P.; MANDELLI, C.S.; TASCO, A.M.P. Comercialização Hortícola: análise de alguns setores do mercado varejista de São Paulo. Informações Econômicas, São Paulo, v.28, n.10, out. 1998

TEIZEN, F.S. Montagem de roteiros e estímulos. In: PERDIGÃO, D.M.; HERLINGER, M.; WHITE, O.M. Teoria e Prática da Pesquisa Aplicada. Rio de Janeiro: Elsevier, 2011. 475 p.

TOGNOLLI, D. Interpretação e Análise - Pesquisa Qualitativa. In: PERDIGÃO, D.M.; HeRlingeR, M.; WHITE, O.M. Teoria e Prática da Pesquisa Aplicada. Rio de Janeiro: Elsevier, 2011. 475 p.

THIRY-CHERQHES, H.R. Saturação em pesquisa qualitativa: estimativa empírica de dimensionamento. Revista Brasileira de Pesquisa de Marketing, Opinião e Mídia, v. 3, n. 2, p. 20-27, 2009

TONDATO, C. O cultivo da niágara rosada como alternativa de renda para agricultura familiar na região de Jales - SP. Sociedade Brasileira de Economia, Administração e Sociologia Rural - Sober. Campo Grande, Mato Grosso do Sul, jul, 2010

TRIVIÑOS, A.N.S. Introdução à pesquisa em ciências sociais: a pesquisa qualitativa em educação. São Paulo. Atlas, 1987.175 p. 
USDA. United States Department of Agriculture. Economic Research Service. Peru: An Emerging Exporter of Fruits and Vegetables. Dez, 2010. Disponível em: <http://www.ers.usda.gov/publications/fts-fruit-and-tree-nuts-outlook/fts34501.aspx>

USDA.United States Department of Agriculture. Global Agricultural Information Reports. Disponível em: <http://gain.fas.usda.gov/Lists/Advanced\%20Search/AllItems.aspx> Acesso em: 14 jul 2014a

USDA. United States Department of Agriculture. Market News and Transportation Data. Disponível em: <http://www.marketnews.usda.gov/portal/fv > Acesso em: 5nov 2014b

VAN RAIJ, B.; CANTARELLA, H.; QUAGGIO, J.A.; FURLANI, A.M.C. Recomendações de adubação e calagem para o Estado de São Paulo, Instituto Agronômico, Fundação IAC: Campinas, 1996. (Boletim Técnico n. 100).

VICENTE, J.R. Competitividade do agronegócio brasileiro, 1997-2003. Agricultura em São Paulo, v. 52, n. 1, p. 5-19, São Paulo, jan./jun. 2005.

VIEIRA-FILHO, J.E.R. Inovação tecnológica e aprendizado agrícola: uma abordagem Shumpeteriana. Tese (doutorado). Universidade Estadual de Campinas, Instituto de Economia. Campinas, SP. 2009.

VITAL, T.W.; MOLLER, H.D.; FAVERO, L.A.; SAMPAIO, Y.S.B.; SILVA, E. A fruticultura de exportação do Vale do São Francisco e a crise econômica: efeitos sobre a convenção coletiva de trabalho 2009-2010. Revista em Agronegócio e Meio Ambiente, v.4, n.3, p. 365-390, set/dez, 2011.

VITTI, A. Análise de competitividade das exportações brasileiras de frutas selecionadas no mercado internacional. Dissertação (mestrado). Escola Superior de Agricultura Luiz de Queiroz/Universidade de São Paulo. Piracicaba, SP. 2009. 106 p.

WERNERFELT, B. A Resource-based View of the Firm. Strategic Management Journal, v. 5, p. 171-180, 1984. 
WUTKE, E.B.; TERRA, M.M.; PIRES, E.J.P.; RIBEIRO, I.J.A.; PECHE-FILHO, A. Produtividade da videira 'niagara rosada' em cultivo intercalar com adubos verdes. Revista Brasileira de Fruticultura, Jaboticabal - SP, Volume Especial, E. 528-535, Outubro, 2011. 


\section{APÊNDICE}

\section{Apêndice A - Roteiro de entrevista para os produtores de uva de mesa}

A. Perfil do entrevistado:

1. Nome:

2. Cidade/estado:

3. Qual o tamanho total de sua propriedade?

4. Quantos hectares são de uva? hectares

5. Qual a produtividade média do seu parreiral?

6. Quantos trabalhadores o Sr.(a) emprega em sua propriedade?

7. O Sr (a). se enquadra na produção familiar? Tem acesso ao Pronaf (P)? ( )Sim ( )Não

8. Se a mão de obra é familiar, quantas pessoas da família auxiliam nas atividades de campo?

9. O Sr. (a) produz outras frutas/produtos na mesma propriedade? Quais?

10. Há quanto tempo oSr. (a) produz uva de mesa?

11. Quais variedades de uva de mesa o Sr.(a) produz?

B. Roteiro de entrevista:

12. Existem Associações/Cooperativas de produtores de uva na sua região? Se sim, o Sr. (a) faz parte? Comente (O que o produtor ganha fazendo parte das cooperativas?).

13. Explique como é a assistência técnica (Engenheiros Agrônomos/Técnicos Agrícolas) para uva de mesa em sua região.

( ) particular ( ) pública ( )da Cooperativa/Associação ( )de empresa de insumos.

14. Comente sobre os órgãos públicos que auxiliam ao produtor em pesquisas e transferência de informação/tecnologia para a cultura da uva de mesa. (Embrapa, por exemplo). 
15. Qual sua opinião sobre o Crédito (de custeio, investimento e comercialização) e Seguro Agrícola? Como está o cenário para o produtor de uva de mesa? O Sr.(a) utiliza algum deles?

16. Tecnologias de campo:

a. Comente sobre irrigação na sua região. (Qual sistema utiliza?).

b. Comente sobre mecanização na uva de mesa para a sua região. (Quais atividades são mecanizadas? O que falta para aumentar o nível de mecanização?)

\section{Atividades passíveis de ser mecanizadas que o produtor utiliza:}

( ) adubação () roçada ( ) pulverização ( ) enxertia ( ) uso de transporte das caixas com uva durante a colheita

\section{Atividades manuais que o produtor faz:}
( ) amarrio
( ) desbrota
( ) poda
( ) colheita
( ) plantio de muda enxertada

( ) embalamento no packing house

c. Explique sobre o sistema de condução da uva em sua propriedade e região (Sistema em ou latada, espaldeira ou $\mathrm{Y}^{18}$ ).

d. Comente sobre melhoramento genético para uva de mesa. Qual sua opinião sobre os transgênicos?

\footnotetext{
${ }^{18}$ São três tipos de sistemas de condução da uva no campo. O sistema em latada é aquele em que a produção de uva se estende horizontalmente na parte de cima da planta, como uma cobertura. O sistema em espaldeira é formado pelas mudas posicionadas lado a lado em uma fileira. Já o sistema em $Y$ tem este nome, pois a videira fica na forma da letra $Y$ no campo, posicionada lado a lado, como no caso da espaldeira.
} 
17. O que o $\mathrm{Sr}$ (a) faz para melhorar a qualidade da sua uva? O $\mathrm{Sr}$ (a) acha que vale a pena investir em materiais genéticos para ter uma uva de melhor qualidade?

18. Como é a troca de informações (sobre comercialização, experiências de campo, etc.) com os produtores de sua (ou de outra) região?

19. Como é feita a comercialização da sua uva? Comente.

(_ $\%$ atacado _ _ _ supermercado _ _ exportação _ _ _ outros___

- Se vende para supermercado: faz contratos com supermercados/atacadistas?

20. Como é a logística da uva que o Sr.(a) vende?

21. Apenas para o Nordeste: há Cooperativa/Associação de exportação? Como funciona em relação aos envios consignados? Há contratos? 
Apêndice B - Principais Programas de Crédito Agrícola disponíveis para o produtor brasileiro de uva de mesa

\begin{tabular}{|c|c|c|c|c|}
\hline $\begin{array}{l}\text { Nome do } \\
\text { Programa }\end{array}$ & Objetivo & Beneficiários & $\begin{array}{c}\text { Enquadramento/Itens } \\
\text { financiáveis }\end{array}$ & Crédito \\
\hline $\begin{array}{l}\text { Programa de } \\
\text { Garantia da } \\
\text { Atividade } \\
\text { Agropecuária } \\
\text { (Proagro) }\end{array}$ & $\begin{array}{c}\text { Garante exoneração de } \\
\text { obrigações financeiras relativas } \\
\text { a operação de crédito de custeio } \\
\text { e indenização de recursos } \\
\text { próprios, no caso de a liquidação } \\
\text { ser dificultada pela ocorrência de } \\
\text { intempéries climáticas, pragas e } \\
\text { doenças . E promoção do uso de } \\
\text { tecnologia. }\end{array}$ & $\begin{array}{l}\text { Pequenos e médios } \\
\text { produtores rurais e } \\
\text { suas cooperativas. }\end{array}$ & \multirow{2}{*}{$\begin{array}{c}\text { O enquadramento no programa } \\
\text { de custeio agrícola está restrito } \\
\text { aos empreendimentos } \\
\text { conduzidos sob as condições do } \\
\text { Zoneamento Agrícola de Risco } \\
\text { Climático (Zarc), divulgados } \\
\text { pelo Mapa. Uva é uma cultura } \\
\text { que está inclusa no Proagro. }\end{array}$} & $\begin{array}{l}\text { Até } \mathrm{R} \$ 300 \mathrm{mil} / \mathrm{beneficiário} \mathrm{no} \\
\text { custeio agrícola por safra. }\end{array}$ \\
\hline $\begin{array}{l}\text { Programa de } \\
\text { Garantia da } \\
\text { Atividade } \\
\text { Agropecuária da } \\
\text { Agricultura } \\
\text { Familiar } \\
\text { (Proagro Mais) }\end{array}$ & $\begin{array}{l}\text { Similar ao Proagro tradicional, } \\
\text { mas serve também para cobrir } \\
\text { parcelas de custeio rural e } \\
\text { investimento, financiadas ou de } \\
\text { recursos próprios. }\end{array}$ & $\begin{array}{l}\text { Pequenos produtores } \\
\text { vinculados ao Pronaf }\end{array}$ & & $\begin{array}{l}\text { Custeio: } 100 \% \text { do valor financiado; } \\
\text { ou até } 65 \% \text { da Receita Líquida } \\
\text { Esperada do Empreendimento, com } \\
\text { limite de R } \$ 7 \text { mil/beneficiário/safra, } \\
\text { em títulos de recursos próprios. } \\
\text { Investimento: limite de R } \$ 5 \\
\text { mil/beneficiário/ano agrícola. }\end{array}$ \\
\hline $\begin{array}{l}\text { Programa } \\
\text { Nacional de } \\
\text { Fortalecimento } \\
\text { da Agricultura } \\
\text { Familiar } \\
\text { (Pronaf) }\end{array}$ & $\begin{array}{l}\text { O Programa estimula a geração } \\
\text { de renda e melhora o uso da mão } \\
\text { de obra familiar por meio do } \\
\text { financiamento de atividades e } \\
\text { serviços rurais. }\end{array}$ & $\begin{array}{c}\text { Produtor familiar que } \\
\text { comprove seu } \\
\text { enquadramento } \\
\text { mediante “Declaração } \\
\text { de Aptidão ao } \\
\text { Pronaf”; não tenha } \\
\text { área superior a } 4 \\
\text { módulos fiscais; } \\
\text { possuam renda bruta } \\
\text { anual de até R\$ } 360 \\
\text { mil }\end{array}$ & $\begin{array}{l}\text { Os créditos de custeio financiam } \\
\text { atividades agropecuárias e de } \\
\text { beneficiamento e os créditos de } \\
\text { investimento se destinam ao } \\
\text { financiamento de atividades para } \\
\text { implantação, ampliação ou } \\
\text { modernização da produção; } \\
\text { ambos com base em projetos. }\end{array}$ & $\begin{array}{c}\text { Para o custeio, o valor pode variar de } \\
\mathrm{R} \$ 10 \text { mil a } \mathrm{R} \$ 100 \\
\text { mil/mutuário/safra, de acordo coma } \\
\text { taxa de juros contratada; Para } \\
\text { investimento, a fruticultura sustenta } \\
\text { valor de até } \mathrm{R} \$ 300 \\
\text { mil/beneficiário/ano agrícola. }\end{array}$ \\
\hline
\end{tabular}




\begin{tabular}{|c|c|c|c|c|}
\hline $\begin{array}{l}\text { Programa } \\
\text { Nacional de } \\
\text { Apoio ao Médio } \\
\text { Produtor Rural } \\
\text { (Pronamp) }\end{array}$ & $\begin{array}{l}\text { Programa de financiamento } \\
\text { relativo a bens e serviços, desde } \\
\text { que constituam um projeto de } \\
\text { investimento e estejam } \\
\text { diretamente relacionados com a } \\
\text { atividade produtiva, e destinados } \\
\text { a promover o aumento da } \\
\text { produtividade e da renda. }\end{array}$ & $\begin{array}{c}\text { Produtores que } \\
\text { tenham, no mínimo, } \\
80 \% \text { de sua renda } \\
\text { bruta anual originária } \\
\text { da atividade } \\
\text { agropecuária. Renda } \\
\text { bruta anual de até R\$ } \\
\text { 1,6 milhão; }\end{array}$ & $\begin{array}{l}\text { Custeio: inclusão de verbas para } \\
\text { atendimento de pequenas } \\
\text { despesas de investimento e } \\
\text { manutenção do beneficiário e de } \\
\text { sua família; } \\
\text { Investimento: financiamento de } \\
\text { custeio associado, limitado a } \\
\text { 30\% (trinta por cento) do valor } \\
\text { total do projeto. }\end{array}$ & $\begin{array}{c}\text { Para o custeio é de } \mathrm{R} \$ 660 \\
\text { mil/beneficiário/safra; Para } \\
\text { investimento é } \mathrm{R} \$ 385 \text { mil por ano } \\
\text { agrícola. }\end{array}$ \\
\hline $\begin{array}{l}\text { Programa de } \\
\text { Incentivo à } \\
\text { Irrigação e à } \\
\text { Armazenagem } \\
\text { (Moderinfra) }\end{array}$ & $\begin{array}{c}\text { Programa que apoia o } \\
\text { desenvolvimento da } \\
\text { agropecuária irrigada, de forma } \\
\text { a minimizar o risco de produção; } \\
\text { ampliação da capacidade de } \\
\text { armazenagem; proteção à } \\
\text { fruticultura contra granizo; e } \\
\text { construção/ampliação de } \\
\text { instalações para guardar } \\
\text { máquinas e implementos } \\
\text { agrícolas. }\end{array}$ & \multirow{2}{*}{$\begin{array}{l}\text { Produtores rurais e } \\
\text { Cooperativas; Como o } \\
\text { Programa é realizado } \\
\text { com recurso do } \\
\text { BNDES, o tomador do } \\
\text { crédito deve } \\
\text { comprovar a } \\
\text { capacidade de } \\
\text { pagamento. }\end{array}$} & $\begin{array}{l}\text { Investimentos relacionados com } \\
\text { itens de sistemas de irrigação, } \\
\text { inclusive infraestrutura elétrica e } \\
\text { reserva de água, e de } \\
\text { armazenamento, inclusive } \\
\text { reforma e construção, } \\
\text { modernização, ampliação de } \\
\text { instalações destinadas à guarda } \\
\text { de máquinas e implementos } \\
\text { agrícolas e à estocagem de } \\
\text { insumos. }\end{array}$ & $\begin{array}{c}\text { Até } \mathrm{R} \$ 2 \text { milhões/beneficiário, para } \\
\text { empreendimento individual; até } \mathrm{R} \$ 6 \\
\text { milhões para empreendimento } \\
\text { coletivo (respeitando o limite } \\
\text { individual). Com prazo de reembolso } \\
\text { de até } 12 \text { anos, com } 3 \text { anos de } \\
\text { carência. }\end{array}$ \\
\hline $\begin{array}{c}\text { Programa de } \\
\text { Modernização } \\
\text { da Agricultura e } \\
\text { Conservação dos } \\
\text { Recursos } \\
\text { Naturais } \\
\text { (Moderagro) }\end{array}$ & $\begin{array}{c}\text { Apoio e fomento a alguns } \\
\text { setores de produção, incluindo a } \\
\text { fruticultura; fomento a ações } \\
\text { relacionadas à defesa animal; } \\
\text { apoio à recuperação dos solos } \\
\text { por meio dos corretivos } \\
\text { agrícolas. }\end{array}$ & & $\begin{array}{l}\text { Investimentos individuais ou } \\
\text { coletivos, que visem a } \\
\text { construção/modernização de } \\
\text { benfeitorias, aquisição de } \\
\text { equipamentos, investimentos ao } \\
\text { suprimento de água, alimentação } \\
\text { e tratamento; obras decorrentes } \\
\text { de projeto de adequação } \\
\text { sanitária e/ou ambiental. }\end{array}$ & $\begin{array}{l}\text { Até } \mathrm{R} \$ 800 \mathrm{mil} / \text { beneficiário e de } \mathrm{R} \$ \\
2,4 \text { milhões para empreendimento } \\
\text { coletivo (respeitando o limite } \\
\text { individual). O prazo de reembolso é } \\
\text { até } 10 \text { anos, com } 3 \text { anos de carência. }\end{array}$ \\
\hline
\end{tabular}




\begin{tabular}{|c|c|c|c|c|}
\hline $\begin{array}{l}\text { Programa de } \\
\text { Modernização } \\
\text { da Frota de } \\
\text { Tratores } \\
\text { Agrícolas e } \\
\text { Implementos } \\
\text { Associados e } \\
\text { Colheitadeiras } \\
\text { (Moderfrota) }\end{array}$ & $\begin{array}{c}\text { Programa incentiva a compra de } \\
\text { tratores e implementos agrícolas, } \\
\text { novos ou usados, com idade } \\
\text { máxima de } 8 \text { anos para tratores, } \\
10 \text { anos para colheitadeiras, e } 5 \\
\text { anos para plantadeiras e } \\
\text { semeadoras. }\end{array}$ & & $\begin{array}{c}\text { Tratores e equipamentos } \\
\text { agrícolas }\end{array}$ & $\begin{array}{l}\text { Financiamento de } 90 \% \text { do valor dos } \\
\text { bens; Para médios produtores } \\
\text { enquadrados como beneficiários do } \\
\text { Pronamp, o valor financiado pode ser } \\
\text { de } 100 \% \text {. Prazo de reembolso é de } \\
\text { até } 8 \text { anos para itens novos e de } 4 \\
\text { anos para os usados. }\end{array}$ \\
\hline $\begin{array}{l}\text { Programa de } \\
\text { Incentivo à } \\
\text { Inovação } \\
\text { Tecnológica na } \\
\text { Produção } \\
\text { Agropecuária } \\
\text { (Inovagro) }\end{array}$ & $\begin{array}{l}\text { Apoiar investimentos de } \\
\text { inovação tecnológica, visando } \\
\text { aumento da produtividade, } \\
\text { adoção de boas práticas e de } \\
\text { gestão da propriedade rural, e à } \\
\text { inserção competitiva dos } \\
\text { produtores rurais nos diferentes } \\
\text { mercados consumidores; }\end{array}$ & & $\begin{array}{l}\text { Equipamentos para proteção de } \\
\text { cultivos; agricultura de precisão; } \\
\text { programas de computadores para } \\
\text { gestão, monitoramento e } \\
\text { automação; consultorias técnica } \\
\text { e gerencial; itens de BPA; e } \\
\text { assistência técnica limitada a } 4 \% \\
\text { do valor total. }\end{array}$ & $\begin{array}{l}\mathrm{R} \$ 1 \text { milhão/beneficiário ou até } \mathrm{R} \$ 3 \\
\text { milhões para empreendimento } \\
\text { coletivo, respeitando sempre o valor } \\
\text { individual. O prazo de reembolso é } \\
\text { de } 10 \text { anos, com carência de } 3 \text { anos. }\end{array}$ \\
\hline $\begin{array}{l}\text { Programa de } \\
\text { Capitalização de } \\
\text { Cooperativas } \\
\text { Agropecuárias } \\
\text { (Procap - Agro) }\end{array}$ & $\begin{array}{l}\text { Promover a recuperação das } \\
\text { cooperativas; disponibilizar } \\
\text { recursos para o capital de giro, } \\
\text { visando atender necessidades } \\
\text { operacionais das cooperativas; e } \\
\text { saneamento financeiro por meio } \\
\text { da integralização de quotas-parte } \\
\text { em cooperativas. }\end{array}$ & $\begin{array}{l}\text { Produtores associados } \\
\text { a cooperativas de } \\
\text { produção } \\
\text { agropecuária, } \\
\text { agroindustrial, } \\
\text { aquícola ou pesqueira } \\
\text { ou as próprias } \\
\text { cooperativas. }\end{array}$ & $\begin{array}{l}\text { Para o produtor: integralização } \\
\text { de quotas-parte do capital social } \\
\text { em cooperativas singulares; Para } \\
\text { a cooperativa singular: } \\
\text { integralização de quotas-parte do } \\
\text { capital social em cooperativas } \\
\text { centrais, capital de giro e crédito } \\
\text { para saneamento financeiro de } \\
\text { quotas dos seus associados; Para } \\
\text { cooperativas centrais: capital de } \\
\text { giro e crédito para saneamento } \\
\text { de quotas de associados. }\end{array}$ & $\begin{array}{c}\text { Para produtor: até } 100 \% \text { do valor da } \\
\text { integralização de sua quota, limitado } \\
\text { a } \mathrm{R} \$ 40 \text { mil. Para cooperativa } \\
\text { singular: Até } \mathrm{R} \$ 50 \text { milhões para } \\
\text { integralização de quota-parte na } \\
\text { cooperativa central e para } \\
\text { saneamento financeiro de quota dos } \\
\text { cooperados; e até } \mathrm{R} \$ 60 \text { milhões para } \\
\text { financiamento de capital de giro. } \\
\text { Para cooperativa central: até } \mathrm{R} \$ 50 \\
\text { milhões para saneamento financeiro } \\
\text { de quota dos cooperados; e até } \mathrm{R} \$ 60 \\
\text { milhões para financiamento de } \\
\text { capital de giro. }\end{array}$ \\
\hline
\end{tabular}

Fonte: Elaborado pela autora a partir de documentos públicos e disponíveis do MAPA, MDA e BNDES 
Apêndice C - Programas públicos para o Seguro Rural

\begin{tabular}{|c|c|c|c|}
\hline Nome & Objetivo & Beneficiários & Valor recebido quando há sinistro \\
\hline $\begin{array}{l}\text { Seguro Agícola - } \\
\text { Programa de } \\
\text { Subvenção ao } \\
\text { Prêmio do Seguro } \\
\text { Rural }\end{array}$ & $\begin{array}{l}\text { Apoio financeiro ao produtor que } \\
\text { queira adquirir um Seguro Rural para } \\
\text { proteção de danos causados nas } \\
\text { lavouras pelas adversidades climáticas, } \\
\text { com a finalidade de recuperar o capital } \\
\text { investido. }\end{array}$ & $\begin{array}{l}\text { A subvenção concedida pelo Mapa pode } \\
\text { ser pleiteada por qualquer produtor que } \\
\text { cultive as espécies contempladas pelo } \\
\text { Programa e permite, também, a } \\
\text { complementação do valor que pode ser } \\
\text { concedido por estados e municípios. }\end{array}$ & $\begin{array}{l}\text { Para uva, a subvenção será de } 60 \% \text { do valor } \\
\text { investido nas principais regiões produtoras } \\
\text { (aquelas que, para uva, são de grande } \\
\text { importância econômica). O limite é de R } \$ 96 \\
\text { mil/beneficiário/ano civil. }\end{array}$ \\
\hline $\begin{array}{l}\text { Seguro da } \\
\text { Agricultura } \\
\text { Familiar (Seaf) }\end{array}$ & $\begin{array}{l}\text { Apoio apenas ao Agricultor Familiar } \\
\text { que queira adquirir seguro contra } \\
\text { perdas provocadas pelo clima, doenças } \\
\text { e pragas sem controle. }\end{array}$ & $\begin{array}{l}\text { Apenas produtores familiares de culturas } \\
\text { que estão no zoneamento agrícola. A uva } \\
\text { é uma cultura excepcional, podendo ser } \\
\text { enquadrados produtores de qualquer } \\
\text { localidade. }\end{array}$ & $\begin{array}{l}\text { Garante todo o valor financiado de custeio e } \\
\text { até } 65 \% \text { da receita líquida esperada, limitado } \\
\text { a } \mathrm{R} \$ 3,5 \text { mil; nas operações de } \\
\text { investimentos, o valor das parcelas é } \\
\text { limitado a } \mathrm{R} \$ 5 \text { mil por ano agrícola, por } \\
\text { agricultor. }\end{array}$ \\
\hline
\end{tabular}

Fonte: Elaborado pela autora a partir de documentos públicos e disponíveis do MAPA e MDA

Apêndice D - Seguro Rural que pode ser contratado pelo produtor de uva junto às seguradoras

\begin{tabular}{|c|l|}
\hline Tipos de Seguro Agrícola & \multicolumn{1}{c|}{ Descrição } \\
\hline Seguro contra granizo & Cobre apenas perdas causadas por chuvas de granizo. Para uva é uma modalidade bastante importante. \\
\hline $\begin{array}{l}\text { Seguro de benfeitorias e } \\
\text { produtos agropecuários }\end{array}$ & $\begin{array}{l}\text { Este seguro cobre perdas e/ou danos causados aos bens que não tenham sido oferecidos em garantia de operações de } \\
\text { crédito rural. Seguro contra riscos de incêndio, raio, explosão, ventos fortes, desmoronamento, roubo ou furto. }\end{array}$ \\
\hline Seguro de penhor rural & $\begin{array}{l}\text { Preserva os bens diretamente relacionados á atividade agrícola que tenham sido oferecidos em garantia de operações } \\
\text { de crédito rural (durante a vigência da apólice). A garantia se estende às benfeitorias, máquinas, veículos e } \\
\text { implementos utilizados na atividade rural, bem como a produtos agropecuários já colhidos, quando forem danificados } \\
\text { por incêndio acidental, explosão, intempéries climáticas, impacto de veículos de qualquer espécie, desmoronamento } \\
\text { de construção, colisão, capotagem ou quedas acidentais, roubo ou furto total. }\end{array}$ \\
\hline
\end{tabular}

Fonte: Elaborado pela autora a partir de documentos públicos e disponíveis do MAPA 


\section{Apêndice E - Modelo estatístico para análise do preço da uva itália}

Dentre várias propostas testadas, ajustou-se um modelo com resposta tendo distribuição gama e função de ligação recíproca. O preditor linear selecionado teve interação significativa entre os anos e as regionais, tendo a seguinte forma:

$\eta=\beta_{0}+\beta_{1} \cdot t+\beta_{2} . X_{1}+\beta_{3} . X_{2}+\beta_{4} . X_{3}+\beta_{5} . t . X_{1}+\beta_{6} . t . X_{2}+\beta_{7} . t . X_{3}$

As variáveis $\mathrm{X} 1, \mathrm{X} 2, \mathrm{X} 3$ representam as regionais, e assumem os seguintes valores:

\begin{tabular}{cccc}
\hline Região & X1 & X2 & X3 \\
\hline Macro Metropolitana Paulista & 0 & 0 & 0 \\
Norte do Paraná & 1 & 0 & 0 \\
São José do Rio Preto & 0 & 1 & 0 \\
Vale do São Francisco & 0 & 0 & 1 \\
\hline
\end{tabular}

A Tabela a seguir mostra as estimativas dos parâmetros e seus respectivos erros-padrão:

\begin{tabular}{ccc}
\hline Parâmetro & Estimativa & $\begin{array}{c}\text { Erro } \\
\text { padrão }\end{array}$ \\
\hline$\beta_{0}$ & 101,4347 & 3,4399 \\
$\beta_{1}$ & $-0,0502$ & 0,0017 \\
$\beta_{2}$ & $-20,1822$ & 5,4243 \\
$\beta_{3}$ & $-29,0755$ & 5,7334 \\
$\beta_{4}$ & $-26,6259$ & 5,8111 \\
$\beta_{5}$ & 0,0101 & 0,0027 \\
$\beta_{6}$ & 0,0144 & 0,0029 \\
$\beta_{7}$ & 0,0132 & 0,0029 \\
\hline
\end{tabular}

A Figura abaixo mostra a qualidade do ajuste do modelo, avaliada por meio de um half-normal plot (Moral et al., 2014). Nota-se que o ajuste foi satisfatório, tendo em vista que os pontos fora da curva somam menos de $5 \%$ do total. 


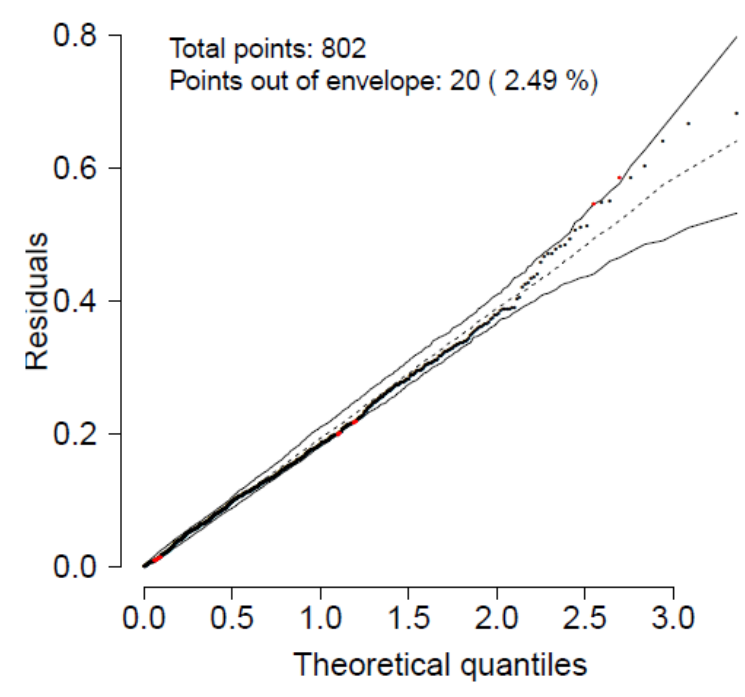

Assim, o preço médio predito $(\hat{y})$ para cada regional de acordo com o ano (t) é dado pelas seguintes equações:

$$
\hat{y}(t)= \begin{cases}\frac{1}{\hat{\beta}_{0}+\hat{\beta}_{1} \cdot t} & \text { se Regional }=\text { M. M. Paulista } \\ \frac{1}{\left(\hat{\beta}_{0}+\hat{\beta}_{2}\right)+\left(\hat{\beta}_{1}+\hat{\beta}_{5}\right) \cdot t} & \text { se Regional }=\text { Norte do Panará } \\ \frac{1}{\left(\hat{\beta}_{0}+\hat{\beta}_{3}\right)+\left(\hat{\beta}_{1}+\hat{\beta}_{6}\right) \cdot t} & \text { se Regional }=\text { São José do Rio Preto } \\ \frac{1}{\left(\hat{\beta}_{0}+\hat{\beta}_{4}\right)+\left(\hat{\beta}_{1}+\hat{\beta}_{7}\right) \cdot t} & \text { se Regional = Vale do São Francisco }\end{cases}
$$

Por fim, mostra-se na Figura a seguir o ajuste do modelo aos dados observados. Note que a presença da interação no modelo faz com que as curvas ajustadas tenham comportamentos diferentes de acordo com a regional ao longo dos anos, chegando algumas a se cruzar (comportamento observado nos dados também).
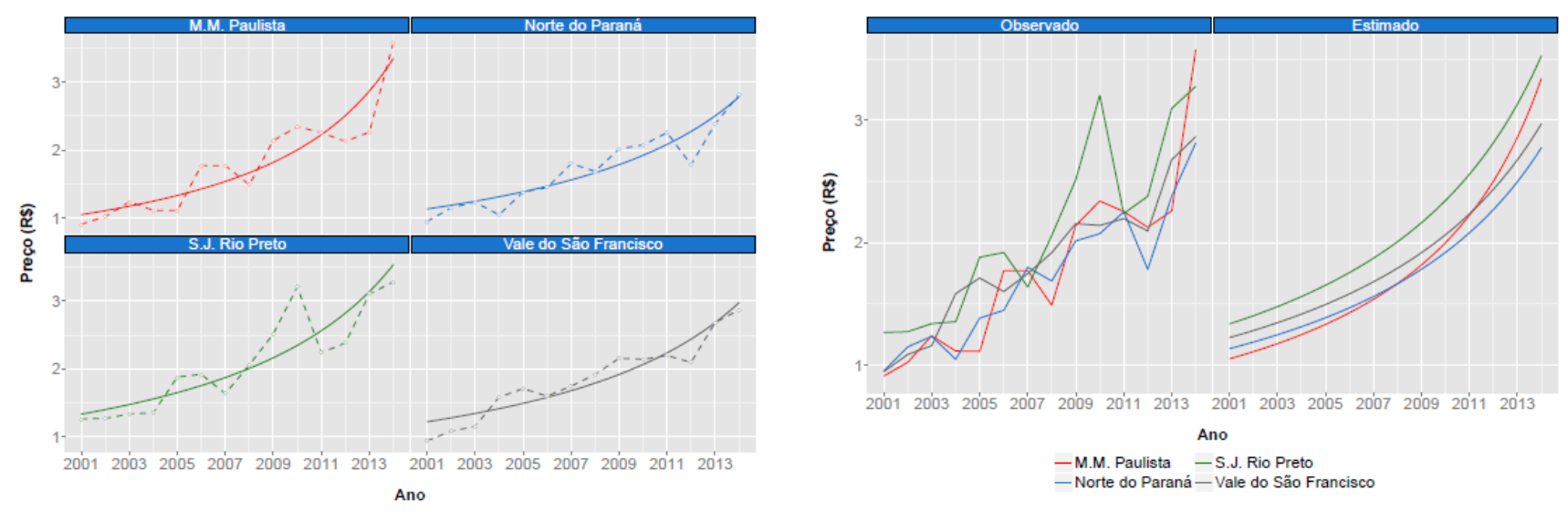


\section{Apêndice F - Modelo estatístico para análise do preço da uva niagara}

A primeira opção foi ajustar um modelo de regressão assumindo distribuição normal para o preço da uva niagara, mas este modelo não obteve um bom ajuste quando foi avaliado o half-normal plot (Moral et al., 2014). A proposta seguinte foi ajustar um MLG com resposta gama e função de ligação recíproca. Contudo, tal modelo também não se ajustou bem devido ao half-normal plot. Observou-se então a discrepância da regional São José do Rio Preto em relação às demais, e com isso foi ajustado um novo modelo com resposta gama e ligação recíproca uma separação com 2 grupos que serão comparados:

Grupo 1: São José do Rio Preto

Grupo 2: Demais regionais (Macro Metropolitana Paulista, Norte do Paraná e Vale do São Francisco)

O preditor linear selecionado no modelo final foi:

$\eta=\beta_{0}+\beta_{1} \cdot t+\beta_{2} \cdot t^{2}+\beta_{3} \cdot X_{1}$,

em que:

\begin{tabular}{cc}
\hline Regional & $\mathbf{X}_{\mathbf{1}}$ \\
\hline Demais regiões & 0 \\
São José do Rio Preto & 1 \\
\hline
\end{tabular}

A tabela abaixo mostra as estimativas dos parâmetros e seus respectivos erros-padrão.

\begin{tabular}{ccc}
\hline Parâmetro & Estimativa & Erro padrão \\
\hline$\beta_{0}$ & 9437 & 1603 \\
$\beta_{1}$ & $-9,364$ & 1,5970 \\
$\beta_{2}$ & 0,002 & 0,0004 \\
$\beta_{3}$ & $-0,174$ & 0,0097 \\
\hline
\end{tabular}

A figura a seguir mostra a qualidade do ajuste do modelo, avaliada por meio de um half-normal plot (Moral et al., 2014). Nota-se que o ajuste foi satisfatório. 


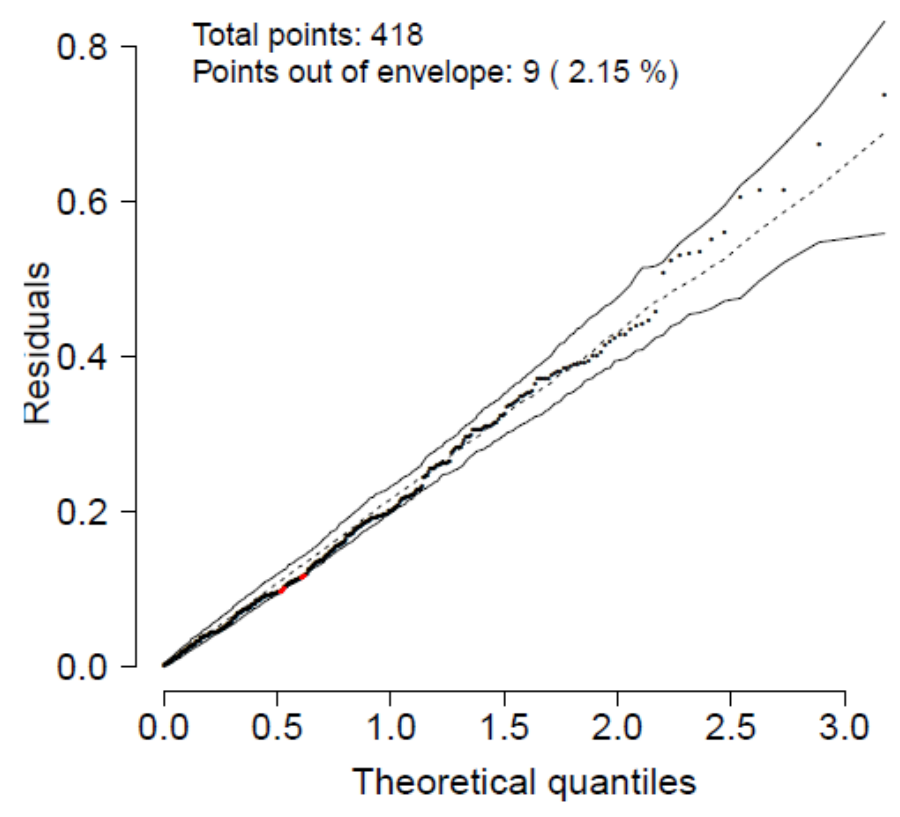

Com isso, o preço médio predito $(\hat{y})$ para cada regional de acordo com o ano (t) é dado pelas seguintes equações:

$$
\hat{y}(t)= \begin{cases}\frac{1}{\hat{\beta}_{0}+\hat{\beta}_{1} \cdot t+\hat{\beta}_{2} \cdot t^{2}} & \text { se Regional }=\text { M.M. Paulista ou Norte Paraná ou Campinas } \\ \frac{1}{\left(\hat{\beta}_{0}+\hat{\beta}_{3}\right)+\hat{\beta}_{1} \cdot t+\hat{\beta}_{2} \cdot t^{2}} & \text { se Regional }=\text { São José do Rio Preto }\end{cases}
$$

Na figura abaixo está o ajuste do modelo aos dados observados.
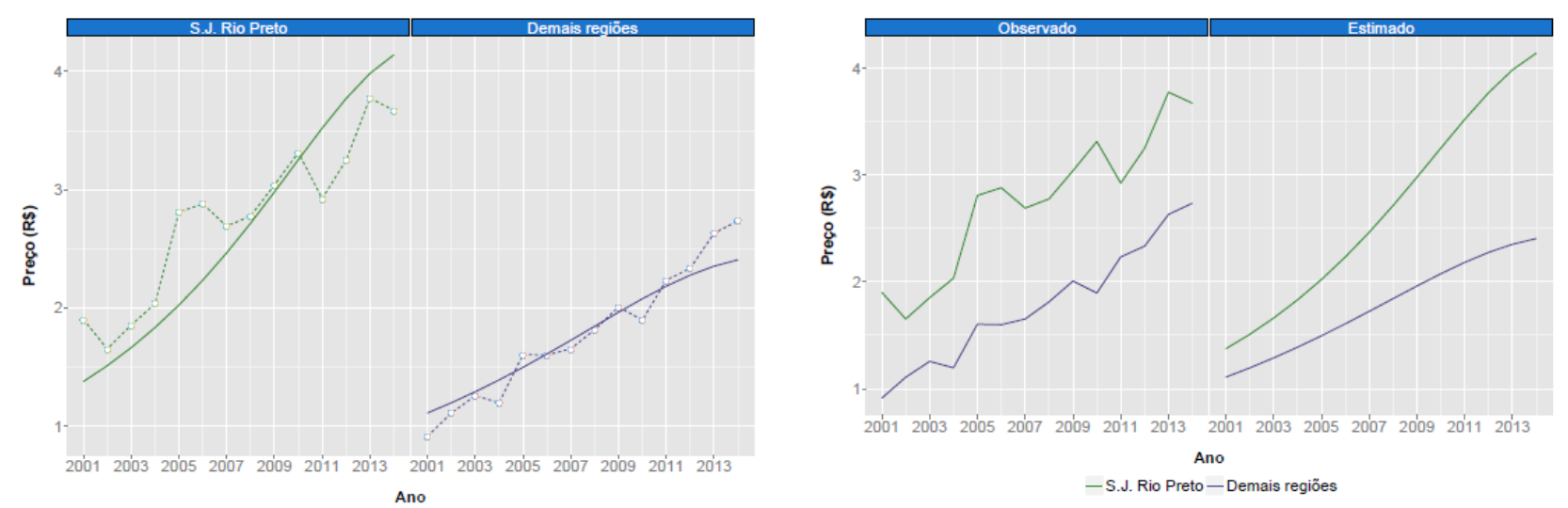